UNIVERSIDADE DE SÃO PAULO

FACULDADE DE ECONOMIA, ADMINISTRAÇÃO E CONTABILIDADE DEPARTAMENTO DE CONTABILIDADE E ATUÁRIA PROGRAMA DE PÓS-GRADUAÇÃO EM CIÊNCIAS CONTÁBEIS

\author{
MANIPULAÇÃO DAS INFORMAÇÕES CONTÁBEIS: \\ UMA ANÁLISE TEÓRICA E EMPÍRICA SOBRE OS MODELOS OPERACIONAIS \\ DE DETECÇÃO DE GERENCIAMENTO DE RESULTADOS
}

Edilson Paulo

Orientador: Prof. Dr. Eliseu Martins 
Prof. Dra. Suely Vilela

Reitor da Universidade de São Paulo

Prof. Dr. Carlos Roberto Azzoni

Diretor da Faculdade de Economia, Administração e Contabilidade

Prof. Dr. Fábio Frezatti

Chefe do Departamento de Contabilidade e Atuária

Prof. Dr. Gilberto de Andrade Martins

Coordenador do Programa de Pós-Graduação em Ciências Contábeis 


\title{
MANIPULAÇÃO DAS INFORMAÇÕES CONTÁBEIS: UMA ANÁLISE TEÓRICA E EMPÍRICA SOBRE OS MODELOS OPERACIONAIS DE DETECÇÃO DE GERENCIAMENTO DE RESULTADOS
}

\author{
Tese apresentada ao Departamento de \\ Contabilidade e Atuária da Faculdade de \\ Economia, Administração e Contabilidade da \\ Universidade de São Paulo como requisito \\ para obtenção do título de Doutor em Ciências \\ Contábeis.
}

Orientador: Prof. Dr. Eliseu Martins 
FICHA CATALOGRÁFICA

Elaborada pela Seção de Processamento Técnico do SBD/FEA/USP

\section{Paulo, Edilson}

Manipulação das informações contábeis: uma análise teórica e empírica sobre os modelos operacionais de detecção de gerenciamento de resultados / Edílson Paulo. -- São Paulo, 2007.

$2 \mathrm{v}$.

Tese (Doutorado) - Universidade de São Paulo, 2007

Bibliografia.

1. Comunicação na contabilidade 2. Valor (Contabilidade) 3. Teoria da mensuração 4. Contabilidade I. Universidade de São Paulo. Faculdade de Economia, Administração e Contabilidade II. Título. 
À minha Mãe, sempre presente espiritualmente.

Te Amo! 
No momento em que concluí este trabalho, olhei para trás e verifiquei que ele só foi possível por causa da participação de muitas pessoas e, por isso, agradeço, aqui, a todos que contribuíram, direta ou indiretamente, para sua conclusão.

Entretanto, não posso deixar de agradecer, de forma especial:

Aos meus amigos da Universidade de São Paulo e Universidade Presbiteriana Mackenzie, pela companhia partilhada dentro e fora da sala de aula.

Aos Professores Alexandro Broedel Lopes, Ariovaldo dos Santos, Carlos Alberto Pereira, Fábio Frezatti, Gilberto de Andrade Martins, Iran Siqueira Lima, Luiz João Corrar, Luiz Nelson Guedes de Carvalho, Luiz Paulo Lopes Fávero e Reinado Guerreiro, pela dedicação e por todo o conhecimento transmitido.

Aos Professores Antônio Lopo Martinez e José Afonso Mazzon, pelas valiosas contribuições dadas quando da qualificação desta tese.

Ao querido Professor e Mestre Eliseu Martins, não só pelos ensinamentos, orientações e incentivo incondicional a este estudo, mas, principalmente, pelo apoio nos momentos difíceis. A cada dia cresce a minha admiração pelo profissional e pela pessoa humana.

A toda minha Família, em especial, ao meu pai Domicio e aos meus filhos Marcelo e Gustavo: Amo vocês!

A minha Mãe do Céu, Nossa Senhora, que ora por mim a cada dia, trazendo-me proteção e paz.

Ao Senhor Meu Deus, pois

“Sois meu refúgio e minha cidadela, Meu Deus, em que eu confio"(Salmo 90). 
"Fazer ou não fazer algo, só depende de nossa vontade e perseverança." 


\section{RESUMO}

Esta tese tem como objetivo principal verificar a validade teórica e empírica dos modelos operacionais para mensurar os accruals discricionários utilizados na detecção de gerenciamento de resultados contábeis. Inicialmente, é apresentada e discutida a informação contábil e sua importância na avaliação do desempenho empresarial e no estabelecimento das relações contratuais, o processo de mensuração contábil e as características institucionais e organizacionais que afetam as escolhas contábeis, características e conseqüências da qualidade das informações contábeis, a discricionariedade dos gestores em relação às perspectivas oportunística e de eficiência das informações contábeis. Por último, é examinado o processo de desenvolvimento e de validação dos modelos teóricos e operacionais na pesquisa analítico-empírica na pesquisa contábil. A seguir, é realizada uma análise teóricocrítica sobre a especificação do modelo geral para detecção de gerenciamento de resultados através das escolhas contábeis e dos modelos operacionais presentes na literatura para a estimação dos accruals discricionários, com base na fundamentação teórica subjacente. Com base nas observações sobre a construção dos modelos analítico-empíricos e evidências empíricas dos trabalhos anteriores, propôs-se um novo modelo para análise do comportamento dos accruals e estimação dos accruals discricionários. Adicionalmente, também se apresentou um modelo para detecção de gerenciamento de resultados que considera os incentivos simultâneos e os custos associados à prática oportunística sobre números contábeis. Este trabalho enquadra-se como uma pesquisa empírico-analítica, utilizando, também, as pesquisas bibliográfica e descritiva. A amostra, neste estudo, é formada pelo conjunto de companhias abertas do mercado de capitais brasileiro, norteamericano e dos demais mercados latino-americanos, compreendendo o período entre 1996 a 2005. A análise da especificação e do poder preditivo dos modelos é desenvolvida por diversos procedimentos estatísticos. Todos os modelos operacionais para mensurar os accruals discricionários utilizados na detecção de gerenciamento de resultados contábeis são estimados através da abordagem pooling of independent cross sections para todos os ambientes econômicos. A escolha do modelo com melhor poder preditivo é realizada pela análise do $R^{2}$ ajustado, critérios de Akaike e de Schwarz e Teste Voung. Os resultados desta pesquisa sugerem que os modelos operacionais de estimação dos accruals discricionários presentes na literatura corrente, de modo geral, não apresentam fundamentação teórica adequada e alguns desses modelos são fracamente especificados e têm baixo poder preditivo, sendo significativamente afetados pelo ambiente econômico. Além disso, os resultados comprovam que o modelo operacional proposto neste trabalho para estimar os accruals discricionários para detecção de gerenciamento de resultados tem maior poder explicativo do comportamento dos accruals em todos os ambientes econômicos analisados. 


\begin{abstract}
This research aims to investigate the theoretical and empirical validity of operational models to measure discretionary accruals used in the detection of earnings management. Initially, accounting information and its importance in business valuation and in the establishment of contractual relations are presented and discussed, as well as the accounting measurement procedure and the institutional and organizational characteristics that affect accounting choices. The characteristics and consequences of accounting information quality and the discretionarity of managers with respect to the opportunistic and efficiency perspectives of accounting information are also addressed. Next, the development and validation process of theoretical and empirical models in analytical and empirical accounting research is examined. This is followed by a theoretical and critical analysis about the specification of the general model to detect earnings management by accounting choices and operational models in literature to estimate discretionary accruals, founded on underlying theoretical premises. Based on observations about the construction of analytical and empirical models and empirical evidence from previous studies, a new model is proposed to analyze accruals behavior and estimate discretionary accruals. Additionally, the study also exhibits a model for earnings management detection that considers the simultaneous incentives and costs associated with the opportunistic practice on accounting figures. This analytic and empirical study also uses bibliographic and descriptive research. The sample, in this study, is composed of public companies from Brazilian, North-American and other Latin-American capital markets, in the period from 1996 to 2005 . The models' specification and predictive power is analyzed through different statistical procedures. All operational models for measuring the discretionary accruals employed in earnings management detection are estimated through the pooling of independent cross sections for all economic environments. The model with the best predictive power is selected by adjusted $R^{2}$, Akaike's and Schwarz' information criteria and the Voung test. The research results suggest that the operational estimation models of discretionary accruals present in current literature do not exhibit adequate theoretical foundations. Some of those models are poorly specified and have low predictive power, besides being significantly affected by the economic environment. Moreover, the results proved that the operational model proposed in this study to estimate discretionary accruals for the detection of earnings management has larger explicative power of accruals behavior in all analyzed economic environments.
\end{abstract}




\section{SUMÁRIO}

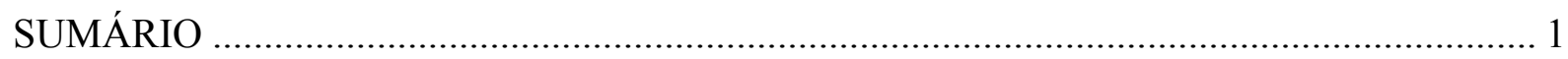

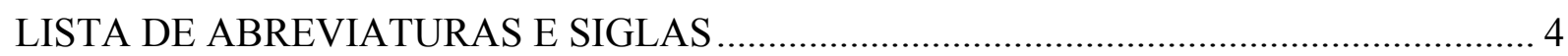

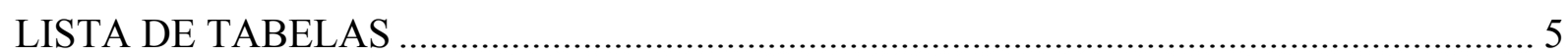

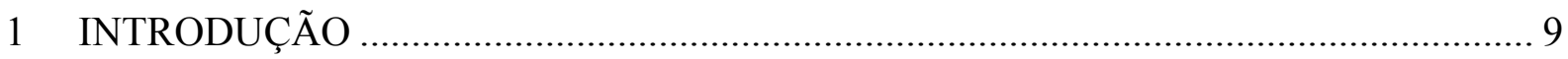

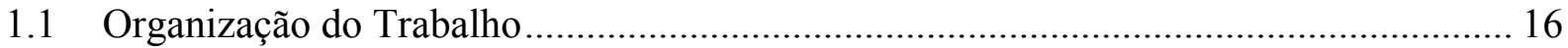

1.2 Problema e Objeto de Estudo e Formulação da Hipótese................................................. 17

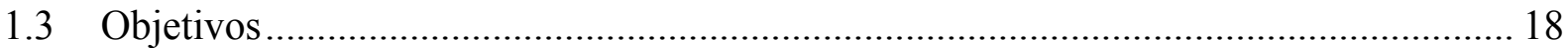

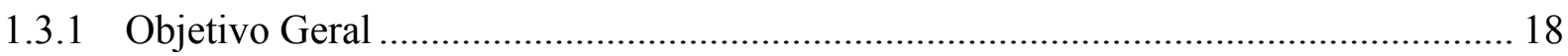

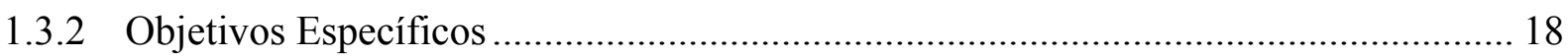

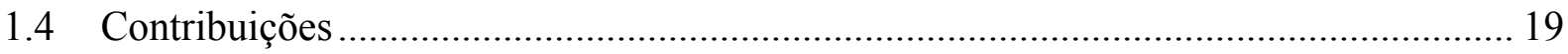

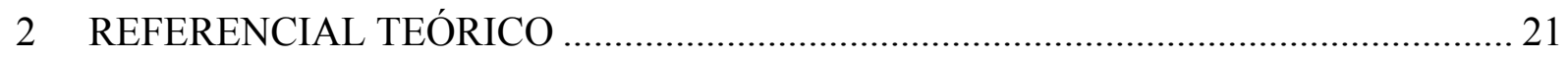

2.1 Escolhas contábeis e os fatores institucionais e organizacionais.................................. 28

2.2 A Contabilidade e os intermediários de informação...................................................... 33

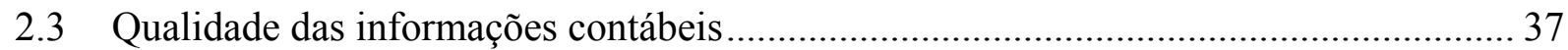

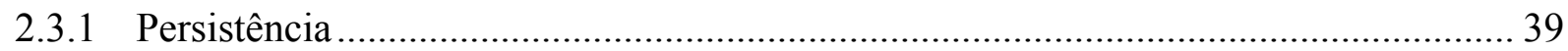

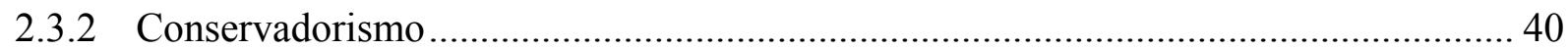

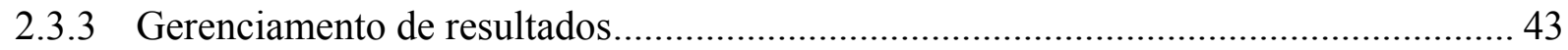

2.4 Manipulação das informações contábeis ........................................................................ 44

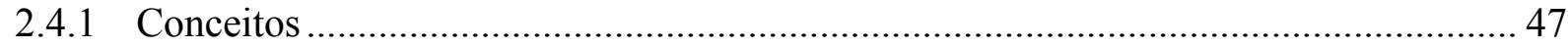

2.4.2 Incentivos para a manipulação das informações contábeis .......................................... 50

2.4.3 Formas de manipulação das informações contábeis.................................................... 58

2.4.4 Influência das características organizacionais e institucionais..................................... 66

2.5 Desenvolvimento de modelos na pesquisa analítico-empírica em Contabilidade.......... 71

3 ANÁlisE DOS MODELOS OPERACIONAIS PARA DETECÇÃO DE GERENCIAMENTO DOS RESULTADOS CONTÁBEIS ................................................ 83

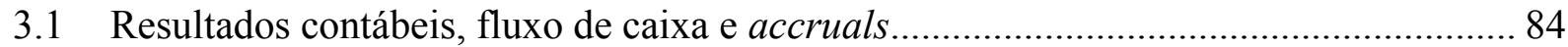

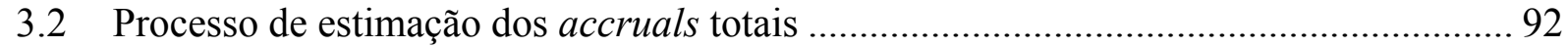

3.3 Modelo para detecção de gerenciamento de resultados através dos accruals ............... 96

3.4 Modelos operacionais para estimação dos accruals não-discricionários e discrionários101

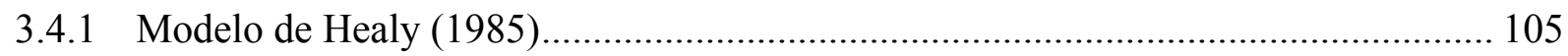

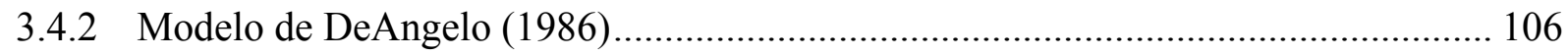




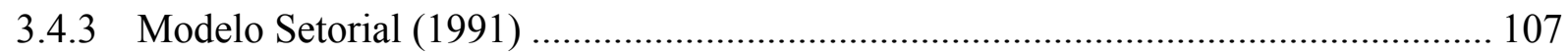

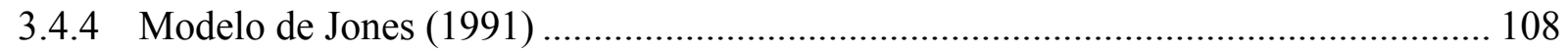

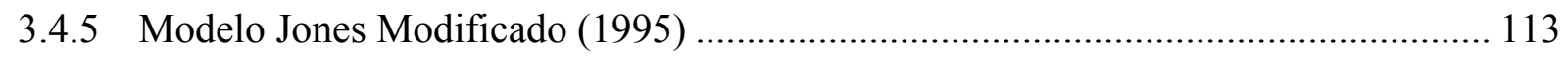

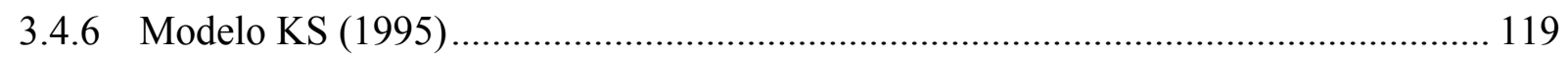

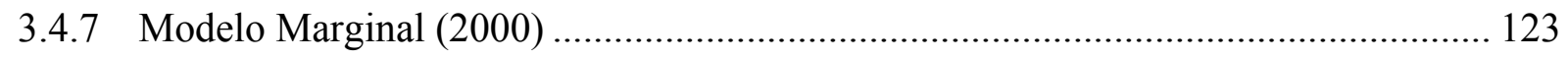

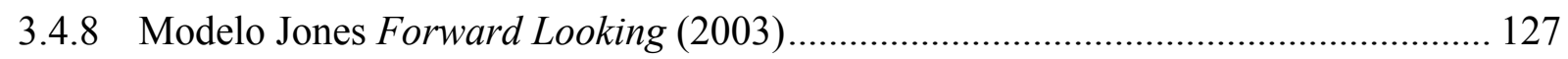

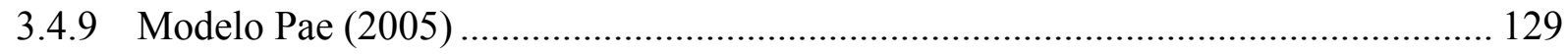

3.4.10 Outras considerações sobre os modelos propostos para estimação dos accruals ...... 132

3.5 Modelos para detecção de gerenciamento de resultados através das atividades operacionais

3.6 Proposta do modelo de estimação dos accruals discricionários para detecção de gerenciamento de resultados

3.6.1 Suposições utilizadas para especificação do modelo proposto para detecção de gerenciamento de resultados e para estimação dos accruals discricionários ......................... 141

3.6.2 Modelo operacional proposto para mensuração dos accruals discricionários ............ 157

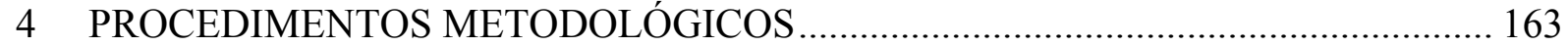

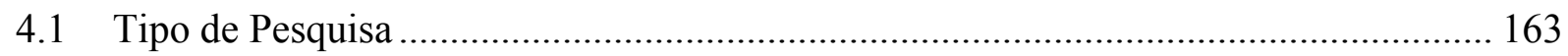

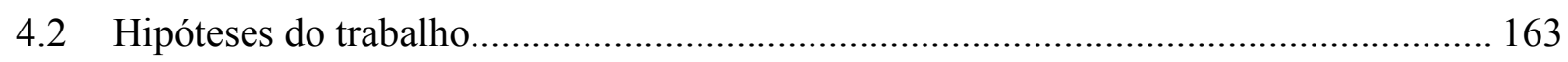

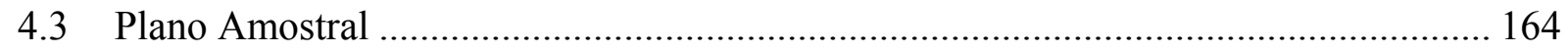

4.4 Definição do modelo empregado e variáveis operacionais ......................................... 165

4.5 Análise da especificação e do poder preditivo de modelos concorrentes...................... 166

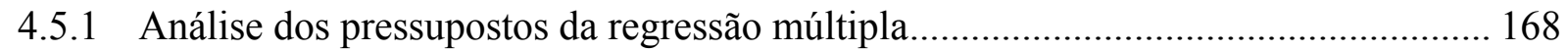

4.5.2 Análise da especificação do modelo e escolha do melhor modelo ............................ 171

5 ANÁLISE DOS DADOS E DA ESPECIFICAÇÃO DOS MODELOS ......................... 177

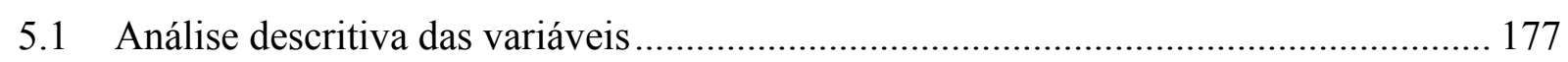

5.2 Análise da especificação dos modelos operacionais para a estimação dos accruals

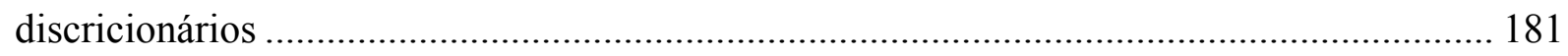

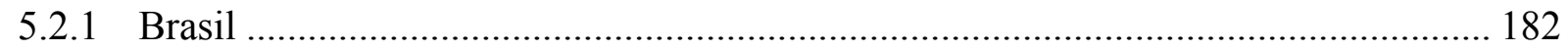

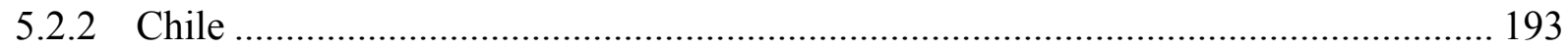

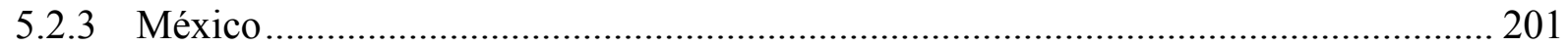

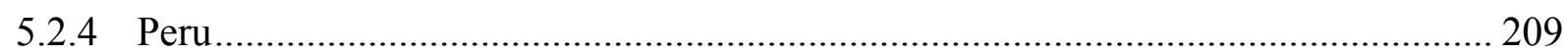

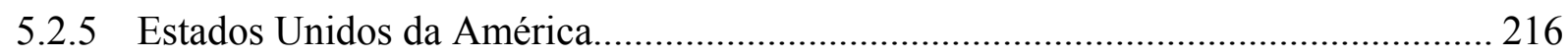

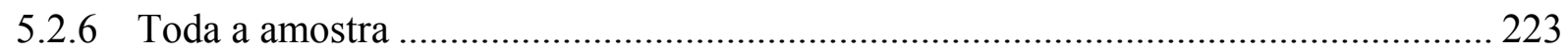

5.3 Análise das suposições e ajustes do modelo proposto .................................................. 232 


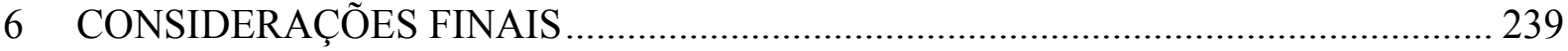

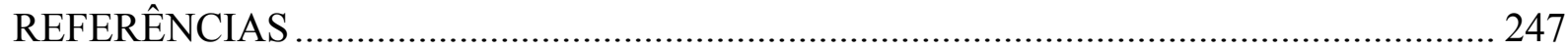

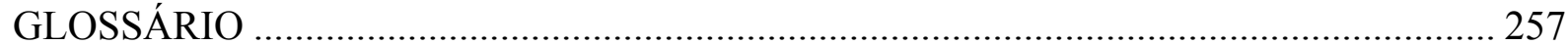




\section{LISTA DE ABREVIATURAS E SIGLAS}

ANS: Agência Nacional de Saúde Suplementar

BACEN: Banco Central do Brasil

CIDE: Contribuição de Intervenção no Domínio Econômico

CSLL: Contribuição Social sobre o Lucro Líquido

Cofins: Contribuição para a Seguridade Social

CPMF: Contribuição Provisória sobre a Movimentação Financeira

CVM: Comissão de Valores Mobiliários

EPS: earnings per share (lucro por ação)

FGTS: Fundo de Garantia por Tempo de Serviço

FIV: Fator de Inflação da Variância (semelhante a VIF)

ICMS: Imposto sobre Operações relativas à Circulação de Mercadorias e sobre Prestações de

Serviços de Transporte Interestadual, Intermunicipal e de Comunicação

IOF: Imposto sobre Operações Financeiras

IPI: Imposto sobre Produtos Industrializados

IPO: Initial Public Offering (Oferta Pública Inicial)

IRPJ: Imposto de Renda da Pessoa Jurídica

ISS: Imposto sobre Serviços de Qualquer Natureza

IV: Variáveis Instrumentais

Jones FL: Jones Forward Looking

KS: modelo operacional proposto por Kang e Sivaramakrishnan (1995)

KB: Koenker-Basset (teste)

MQO: Método dos Quadrados Ordinários

PASEP: Programa de Formação do Patrimômio do Servidor Público

P\&D: Pesquisa e Desenvolvimento

PIS: Programa de Integração Social

RM: gerenciamento das atividades operacionais (reais)

RV: razão de verossimilhança

SPSS: Statistical Package for Social Science

VIF: Variance Inflation Factor (semelhante a FIV) 


\section{LISTA DE TABELAS}

Tabela 1 - Ofertas primárias registradas na CVM de janeiro de 1997 a julho de 2007. ..... 52 Tabela 2 - Arrecadação das receitas administradas pela Secretaria da Receita Federal -

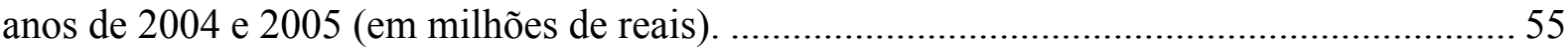

Tabela 3 - Diferença temporal entre o resultado contábil e o fluxo de caixa e a Lei da Conservação dos Resultados 87

Tabela 4 - $\quad$ Exemplo do Modelo Jones - Demonstrações Contábeis ................................. 111

Tabela 5 - Exemplo do Modelo Jones - Dados para regressão......................................... 112

Tabela 6 - Exemplo do Modelo Jones - Estimação dos accruals discricionários .............. 112 Tabela 7 - Exemplo 1 do Modelo Jones modificado - Estimação dos accruals

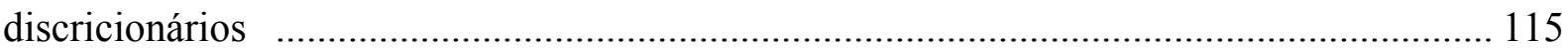

Tabela 8 - Exemplo 2 do Modelo Jones Modificado - Demonstrações Contábeis........... 116

Tabela 9 - Exemplo 2 do Modelo Jones Modificado - Dados para regressão ................... 116

Tabela 10 - Exemplo 2 do Modelo Jones Modificado - Estimação dos accruals discricionários

Tabela 11 - Exemplo 2 do Modelo Jones Modificado - Comparação entre os accruals reais e estimados

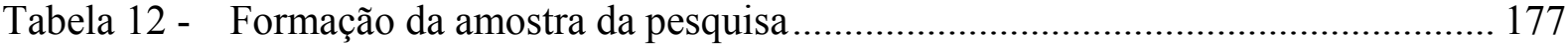

Tabela 13 - Composição da amostra de cada país ................................................................ 178

Tabela 14 - Estatística descritiva das variáveis ............................................................... 179

Tabela 15 - Análise de correlação de Pearson....................................................................... 180

Tabela 16 - Análise de correlação de Spearman ................................................................ 181

Tabela 17 - Estimação dos modelos operacionais no contexto brasileiro - Parte A........... 183

Tabela 18 - Estimação dos modelos operacionais no contexto brasileiro - Parte B ........... 184

Tabela 19 - Estimação dos modelos operacionais no contexto brasileiro - Parte C ........... 186

Tabela 20 - Gerenciamento de atividades operacionais no contexto brasileiro .................. 187

Tabela 21 - Teste de multicolineariedade Variance Inflation Factor no contexto brasileiro

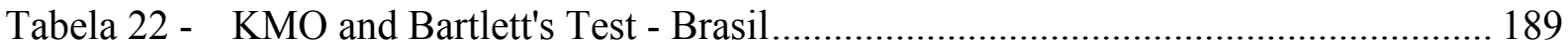

Tabela 23 - Comparação do ajuste dos modelos operacionais no contexto brasileiro ........ 189

Tabela 24 - Comparação dos modelos operacionais no contexto brasileiro - Teste Vuong 190 
Tabela 25 - Testes de variáveis redundantes para as proxies de gerenciamento de atividades operacionais - Brasil.

Tabela 26 - Testes de variáveis redundantes para as proxies de conservadorismo - Brasil 191 Tabela 27 - Grau de ajustamento $\left(\mathrm{R}^{2}\right.$ ajustado) dos modelos com dados em painel no contexto brasileiro.

Tabela 28 - Estimação dos modelos operacionais no contexto chileno - Parte A ............... 194

Tabela 29 - Estimação dos modelos operacionais no contexto chileno - Parte B .............. 195

Tabela 30 - Estimação dos modelos operacionais no contexto chileno - Parte C .............. 196

Tabela 31 - Gerenciamento de atividades operacionais no contexto chileno...................... 197

Tabela 32 - Comparação do ajuste dos modelos operacionais no contexto chileno ............ 198

Tabela 33 - Comparação do ajuste dos modelos operacionais no contexto chileno - Teste Vuong

Tabela 34 - Teste de multicolineariedade Variance Inflation Factor no contexto chileno. 199

Tabela 35 - KMO and Bartlett's Test - Chile 199

Tabela 36- Testes de variáveis redundantes para as proxies de gerenciamento de atividades operacionais - Chile

Tabela 37 - Testes de variáveis redundantes para as proxies de conservadorismo - Chile. 200

Tabela 38 - Estimação dos modelos operacionais no contexto mexicano - Parte A .......... 201

Tabela 39 - Estimação dos modelos operacionais no contexto mexicano - Parte B........... 203

Tabela 40 - Estimação dos modelos operacionais no contexto mexicano - Parte C........... 204

Tabela 41 - Gerenciamento de atividades operacionais no contexto mexicano .................. 205

Tabela 42 - Comparação do ajuste dos modelos operacionais no contexto mexicano........ 205

Tabela 43 - Comparação do ajuste dos modelos operacionais no contexto mexicano -

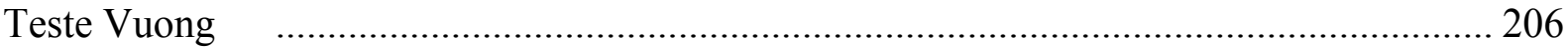

Tabela 44 - Testes de variáveis redundantes para as proxies de gerenciamento de atividades operacionais - México

Tabela 45 - Testes de variáveis redundantes para as proxies de conservadorismo México

Tabela 46- Teste de multicolineariedade Variance Inflation Factor no contexto mexicano 208

Tabela 47 - KMO and Bartlett's Test - México .................................................................... 208

Tabela 48 - Estimação dos modelos operacionais no contexto peruano - Parte A ............. 209

Tabela 49 - Estimação dos modelos operacionais no contexto peruano - Parte B ............. 210

Tabela 50 - Estimação dos modelos operacionais no contexto peruano - Parte C ............. 211 
Tabela 51 - Gerenciamento de atividades operacionais no contexto peruano

Tabela 52 - Comparação do ajuste dos modelos operacionais no contexto peruano

Tabela 53 - Comparação do ajuste dos modelos operacionais no contexto peruano através do teste Vuong (nonnested model)

Tabela 54 - Testes de variáveis redundantes para as proxies de gerenciamento de atividades operacionais - Peru.

Tabela 55 - Testes de variáveis redundantes para as proxies de conservadorismo - Peru .. 214

Tabela 56 - Teste de multicolineariedade Variance Inflation Factor no contexto peruano 215

Tabela 57 - KMO and Bartlett's Test - Peru

Tabela 58 - Estimação dos modelos operacionais no contexto norte-americano - Parte A 216

Tabela 59 - Estimação dos modelos operacionais no contexto norte-americano - Parte B 217

Tabela 60 - Estimação dos modelos operacionais no contexto norte-americano - Parte C 218 Tabela 61 - Comparação do ajuste dos modelos operacionais no contexto norte-americano

Tabela 62 - Comparação do ajuste dos modelos operacionais no contexto norte-americano

- Teste Vuong 220

Tabela 63 - Gerenciamento de atividades operacionais no contexto norte-americano 220

Tabela 64 - Testes de variáveis redundantes para as proxies de gerenciamento de atividades operacionais - EUA

Tabela 65 - Testes de variáveis redundantes para as proxies de conservadorismo - EUA.. 221

Tabela 66 - $\quad$ Teste de multicolineariedade Variance Inflation Factor no contexto norteamericano

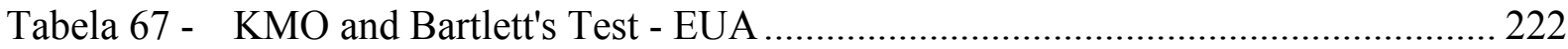

Tabela 68 - Estimação dos modelos operacionais com a amostra geral- Parte A .............. 224

Tabela 69 - Estimação dos modelos operacionais com a amostra geral - Parte B.............. 225

Tabela 70 - Estimação dos modelos operacionais com a amostra geral - Parte C.............. 227

Tabela 71 - Gerenciamento de atividades operacionais - Amostra Geral .......................... 228

Tabela 72 - Teste de multicolineariedade Variance Inflation Factor - Amostra Geral ...... 229

Tabela 73 - KMO and Bartlett's Test - Amostra Geral..................................................... 229

Tabela 74 - Comparação do ajuste dos modelos operacionais - Amostra Geral ................. 230

Tabela 75 - Comparação dos modelos operacionais na Amostra Geral - Teste Vuong ...... 230

Tabela 76- Testes de variáveis redundantes para as proxies de gerenciamento de atividades operacionais - Amosta Geral ...................................................................... 231 
Tabela 77 - Testes de variáveis redundantes para as proxies de conservadorismo -

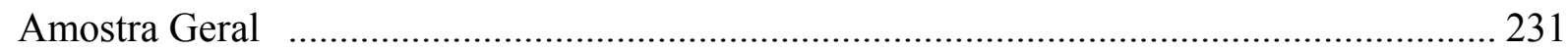

Tabela 78 - Comparação das estatísticas do modelo proposto ............................................ 234

Tabela 79 - Comparação das estatísticas do modelo proposto sem conservadorismo ........ 235 


\section{INTRODUÇÃO}

A “informação é um recurso econômico valioso." (Nicholson, 2002, p.225)

A afirmação acima sintetiza a importância da informação nas atividades econômicas, sociais e políticas, tornando-se um dos objetos de pesquisa mais relevantes, principalmente a partir de meados da década de 1960 entre as diversas áreas do conhecimento.

Estudar a informação, entretanto, tem sido uma tarefa árdua, pois ela não é fácil de ser definida, pois assume muitas características subjetivas e mutáveis ao longo do tempo, ou mesmo, de um indivíduo para o outro.

Adicionalmente, observa-se que uma série de fatores sociais, econômicos, políticos e comportamentais fazem com que os diversos agentes econômicos não possuam a mesma informação, em termos de quantidade e/ou qualidade. Scott (2003, p.105) explica que "freqüentemente, um tipo de participante no mercado (vendedor, por exemplo) conhecerá algo a mais sobre o ativo que está sendo negociado que outro tipo de participante (comprador) não sabe”. Essa situação em que um dos participantes possui melhores informações do que outro(s) participante(s) é conhecida como assimetria da informação ou assimetria informacional.

De forma mais ampla, pode-se considerar que a assimetria informacional, normalmente, ocorre quando um determinado agente ou grupo de agentes presentes no ambiente econômico tem melhores informações sobre o potencial econômico do ativo do que um outro agente ou grupo de agentes.

A Teoria Contratual da Firma descreve que a empresa é considerada um conjunto de contratos entre os diversos agentes econômicos e que cada um deles contribui com algo para o processo produtivo da firma (por exemplo, mão-de-obra, habilidades técnicas e administrativas, capital, matéria-prima e insumos, tecnologia) e, em contrapartida, recebe algo em troca. Watts e Zimmerman (1986, p. 195) afirmam que "a firma é observada como uma equipe de

\footnotetext{
${ }^{\prime}$ Tradução livre de: "Information is a valuable economic resource."

${ }^{2}$ Tradução livre de: "Frequently, one type of participant in the market (sellers, for example) will know something about the asset being traded that another type of participant (buyers) does not know."
} 
individuos com interesses próprios no qual reconhecem que as suas riquezas particulares dependem do sucesso da firma em competição com as outras empresas "’.

Entretanto, cada agente espera maximar a sua própria riqueza (utilidade) e não a do grupo de agentes relacionadas com a firma. Diante desse conflito de interesses, surge a necessidade do estabelecimento de contratos que especifiquem os direitos e obrigações de cada agente em relação à firma. Essas relações contratuais são de diversas naturezas e podem ser explícitas ou não, inclusive sem uma estrutura legal formalizada.

O funcionamento adequado da firma depende do equilíbrio contratual, porém, na prática, alguns problemas surgem, pois os agentes operam em situações de (LOPES; MARTINS, 2005, p.33):

a) Informação imperfeita: refere-se à situação na qual as regras do jogo são bastante claras e todos as conhecem, mas os agentes não conhecem as ações dos outros agentes.

b) Informação incompleta: em que nem mesmo as regras do jogo estão totalmente claras.

Os contratos não reduzem os custos dos conflitos pois podem não ser cumpridos integralmente por uma das partes. Conseqüentemente, existe uma demanda para a monitoração dos contratos (WATTS; ZIMMERMAN, 1986, p. 195). Sunder (1997, p.7) afirma que a Contabilidade possui cinco funções na implementação e execução do conjunto de contratos de uma organização:

a) Mensurar as contribuições de cada participante;

b) Mensurar e auxiliar na distribuição dos direitos de cada participante;

c) Reportar aos participantes com relação ao cumprimento dos contratos;

d) Distribuir informações aos potenciais participantes para manter a liquidez do mercado no qual a empresa tem captado recursos;

e) Distribuir algumas informações como conhecimento comum com a finalidade de reduzir o custo da negociação dos contratos.

Assim, um dos principais papéis da Contabilidade, dentro da dinâmica empresarial, está na redução da assimetria informacional, minimizando os conflitos de interesses e, conseqüentemente, contribuindo para a adequada alocação dos recursos disponíveis, fazendo portanto parte do sistema de governança. O conjunto de relatórios contábeis é base para uma ampla extensão da análise empresarial e é utilizado como meio importante para a

\footnotetext{
${ }^{3}$ Tradução livre de: "The firm is viewed as a team of self-interested individuals who recognize that their own welfare dependes on the firm's success in competition with other firms."
} 
administração comunicar o desempenho da empresa e o mecanismo de governança aos investidores (PALEPU et al, 2004, p.iii).

Seguindo a linha de redução de assimetria informacional, diversos estudos analisam a qualidade da informação contábil e suas implicações no processo de avaliação de desempenho e nas relações contratuais das empresas. Lopes e Martins (2005, p.31) afirmam que "normalmente, os níveis de assimetria são intermediários entre a assimetria total e a simetria total", e ressaltam que a falta de homogeneidade de informações pode ocorrer inclusive entre as classes de investidores (mais sofisticados e menos sofisticados ou individuais). Um melhor nível de informação reduz a assimetria e, conseqüentemente, pode reduzir a incerteza e conduzir o usuário para melhores decisões, aumentando a probabilidade de maior eficiência econômica. Cabe ressaltar que nem sempre a melhor decisão leva aos melhores resultados, devido à incerteza dos cenários em que julgamentos são realizados.

No intuito de agregar mais informações para os seus diversos usuários, a Contabilidade incorporou, ao longo do tempo, uma série de conceitos econômicos para apresentar o mais fidedignamente possível a realidade da empresa dentro de seus relatórios, tais como: confiabilidade, comparabilidade, relevância e regime de competência.

A magnitude da influência do regime de competência (accrual basis) e outros conceitos contábeis, entretanto, mudam conforme a estrutura institucional e organizacional na qual a firma está inserida, como sistema de governança, auditoria, regulação contábil e sistema de normas, enforcement, tributação, relações jurídicas dos contratos, investidores, etc.

Voltando à questão da assimetria informacional, sob a ótica do problema da relação agenteprincipal, diversos estudos empíricos apresentam um conjunto de incentivos para o agente (administrador) agir oportunisticamente na escolha entre os critérios alternativos de mensuração e/ou de evidenciação da informação contábil. Para Pindyck e Rubinfeld (2006, p.541), "o problema da relação agente-principal surge quando os agentes perseguem seus próprios objetivos, e não os do principal'. Considera-se agente o indíviduo contratado pelo principal para obter certo(s) objetivo(s) estabelecido(s) por ele, enquanto o principal é a pessoa que contrata um ou mais agentes para alcançar seu(s) objetivo(s).

Parte dessas pesquisas concentra-se na verificação das hipóteses levadas sobre a manipulação das informações contábeis, como, por exemplo, evitar a divulgação de perdas ou declínio dos resultados contábeis, incluindo suavização dos resultados ao longo do tempo (DECHOW et al, 1995; BURGSTAHLER; DICHEV, 1997; MARTINEZ, 2001; FUJI, 2004; TUKAMOTO, 2004; ZENDERSKY, 2005; CARDOSO, 2005); aumentar a remuneração variável dos administradores (HEALY; WAHLEN, 1999; MARTINEZ, 2001; BARTOV; MOHANRAM, 
2004) ou minimizar a variabilidade dos erros de previsão dos analistas (MARTINEZ, 2001; BARTOV et al, 2002).

Embora em muitos trabalhos o termo 'gerenciamento de resultados' seja utilizado de forma ampla, na qual incorpora todas as ações propositais dos administradores que alteram as informações com o intuito de afetar a avaliação e/ou a tomada de decisão dos usuários da Contabilidade, pode-se, nesse momento do trabalho, fazer uma breve distinção dos termos utilizados na literatura ${ }^{4}$.

O termo 'manipulação' significa "ato ou efeito de manipular", enquanto 'manipular' representa "interferir" (MICHAELIS, 1998, p.1315). Apesar do sentido sociológico/antropológico negativo dado ao termo 'manipulação', esse apresenta-se mais adequado, pois descreve o fenômeno, objeto do presente estudo, ou seja, o de interferir no processo de informação contábil.

Portanto, este trabalho considera que a manipulação das informações contábeis é o conjunto de práticas desenvolvidas pelos administradores, seja através das escolhas das contábeis ou alteração das atividades operacionais (reais) normais da empresa, com o objetivo de interferir, intencionalmente, na informação contábil reportada e, conseqüentemente, afetar a análise do desempenho da empresa ou influenciar as relações contratuais que dependam dos números contábeis. A manipulação da informação contábil pode ser classificada em: (1) gerenciamento de resultados através das escolhas contábeis (principalmente, accruals), (2) gerenciamento de resultados através das atividades operacionais e (3) manipulação classificatória das demonstrações contábeis. O objeto de estudo deste trabalho é o gerenciamento de resultados através dos accruals e das atividades operacionais.

Os resultados contábeis podem ser afetados propositalmente pelas atividades operacionais ou escolhas contábeis. A manipulação das atividades operacionais (reais) ocorre quando os administradores modificam as práticas operacionais normais com o objetivo de alterar os números contábeis e, conseqüentemente, afetar a percepção dos interessados na firma em relação ao seu desempenho e cumprimento dos contratos.

O gerenciamento de resultados pode também ocorrer quando os administradores utilizam do seu julgamento sobre as escolhas contábeis, em particular, sobre os accruals, para alterar os relatórios contábeis com o intuito de modificar a avaliação do desempenho e influenciar as

\footnotetext{
${ }^{4} \mathrm{Na}$ seção 2.4 deste trabalho são apresentados, de forma mais aprofundada, os conceitos, formas e características da manipulação das informações contábeis.
} 
relações contratuais da empresa. Os accruals $^{5}$ são componentes dos resultados contábeis que ajustam o reconhecimento do fluxo de caixa ao longo do tempo, com o objetivo de melhorar a mensuração do desempenho econômico da firma.

Graham et al (2005) realizaram uma pesquisa com mais de 400 executivos de empresas norteamericanas com o intuito de identificar quais os principais fatores que direcionam as decisões sobre resultados reportados e disclosure. Eles relatam que $78 \%$ dos entrevistados gerenciam os resultados contábeis para algumas finalidades de curto prazo, em detrimento do valor da firma no longo prazo. Isso demonstra a relevância que o tema tem no meio profissional e a importância das pesquisas que buscam descrever e compreender tais fenômenos. Segundo o estudo, a principal explicação para tal comportamento dos gestores é a forte reação do mercado aos números indesejáveis no curto prazo.

As pesquisas empíricas sobre gerenciamento de resultados baseadas em accruals buscam identificar e mensurar a parcela das acumulações que foram gerenciadas (accruals discricionários) pelas escolhas contábeis através de modelos operacionais. Entre os modelos desenvolvidos com o objetivo de mensurar a parcela dos accruals discricionários, proxy para o gerenciamento de resultados, os mais presentes na literatura contábil são (MARTINEZ, 2001; TUKAMOTO, 2004):
a) Modelo Healy (1985);
b) Modelo DeAngelo (1986);
c) Modelo Jones (1991);
d) Modelo Jones modificado (DECHOW et al, 1995) e
e) Modelo KS (KANG; SIVARAMAKRISHNAN, 1995).

Apesar de amplamente utilizados em pesquisas empíricas, os modelos baseados em accruals são criticados por parte dos pesquisadores (McNICHOLS, 2000; BENEISH, 2001), pois falham na distinção das acumulações resultantes das mudanças ocasionadas pelo próprio ambiente econômico e as originadas pela manipulação dos dados contábeis. Logo, a mensuração dos accruals discricionários não seria uma boa proxy para a avaliação do nível de gerenciamento de resultados (BARTOV; MOHANRAM, 2004).

\footnotetext{
${ }^{5}$ Neste estudo, os termos 'acumulações gerenciadas', 'acumulações discricionárias', 'acumulações anormais', 'managed accruals', 'discretionary accruals' e 'abnormal accruals' são empregados como sinônimos; da mesma forma que, acumulações não-gerenciadas', 'acumulações não-discricionárias', 'acumulações normais', 'unmanaged accruals', 'non-discretionary accruals' e 'normal accruals' têm o mesmo significado. Normalmente, serão utilizados os termos originais na língua inglesa, por observar que não existe um consenso na sua tradução para a língua portuguesa. Cabe salientar, também que os termos 'demonstrações contábeis', 'demonstrações financeiras' e 'relatórios contábeis’ têm o mesmo significado neste trabalho.
} 
Adicionalmente, as evidências apresentadas pelos trabalhos, nessa linha de pesquisa, são questionadas devido à má especificação ou pobre poder explicativo dos modelos operacionais utilizados nas pesquisas empíricas. Peasnell et al (2000, p.318) afirmam que as razões de os modelos de detecção de gerenciamento de resultados serem ou não adequados em determinados ambientes ainda não estão claras.

Uma das principais dificuldades no desenvolvimento e utilização desses modelos está na necessidade em segmentar com acurácia os componentes gerenciados dos não-gerenciados dos accruals totais.

Apesar de os vários agentes econômicos utilizarem a Contabilidade para diversos propósitos, a maior parte da literatura atual sobre gerenciamento de resultados concentra-se nos danos causados aos investidores e ao mercado de capitais pelas informações contábeis manipuladas, ficando à margem os efeitos causados sobre os demais usuários. Além disso, Stolowy e Breton (2004; p. 6) comentam que os trabalhos sobre esse tema, geralmente, cobrem um único aspecto de manipulação e raramente revisam trabalhos publicados fora dos Estados Unidos da América.

Bushman e Smith (2001) afirmam que existem diferenças entre os países em relação aos sistemas contábeis e ao desempenho econômico, inclusive diversas características institucionais e o ambiente social, legal e político que afetam as informações contábeis. Portanto, observa-se a necessidade do desenvolvimento de pesquisas sobre a influência das características idiossincráticas nacionais sobre os números contábeis e, especificamente neste trabalho, sobre os efeitos das ações discricionários dos administradores, quando da elaboração dos relatórios contábeis da empresa.

De modo geral, observa-se que as pesquisas realizadas dentro do contexto brasileiro estão, basicamente, testando as mesmas hipóteses sobre os incentivos para discricionariedade dos gestores ou fatores institucionais e organizacionais de outros ambientes econômicos, em particular, a realidade anglo-saxônica.

Dentre algumas características distintas da realidade brasileira em relação a outros mercados e que, conseqüentemente, levam a incentivos diferentes, têm-se:

a) Políticas econômicas adotadas pelos governos locais;

b) Sistema tributário e sua relação com os números contábeis;

c) Processo de regulação e monitoramento do mercado financeiro e de capitais;

d) Fontes de captação de recursos das empresas;

e) Concentração de capital votante entre os acionistas, bem como as garantias asseguradas aos minoritários. 
Outro incentivo para o desenvolvimento de pesquisas com a observação de fatores locais seria que:

\begin{abstract}
A pesquisa em contabilidade financeira, principalmente em um país como o Brasil, com suas características tão peculiares, pode ser bastante enriquecedora pelo entendimento mais detalhado dos reais incentivos presentes na atuação dos administradores. (IUDÍCIBUS; LOPES, 2004, p.182).
\end{abstract}

Diante disso, os modelos teóricos e operacionais utilizados em ambientes econômicos diferentes de onde surgiram originalmente, podem apresentar, além da ausência de suporte teórico, evidências inadequadas ou estatisticamente insatisfatórias devido aos problemas de erro de especificação e/ou de mensuração das variáveis. As pesquisas nacionais devem observar os fatores que influenciam as características das informações contábeis reportadas pelas empresas em seus ambientes empresariais, buscando capturar as variáveis mais adequadas, com o objetivo de desenvolver estudos mais robustos e apresentar melhores evidências. Adicionalmente, as pesquisas locais contribuem para a melhor compreensão dos fenômenos quando da análise de cenários internacionais, pois permitem controlar as características peculiares de cada país.

Além do mais, os estudos sobre o comportamento dos accruals tem sido de grande importância em outras linhas de pesquisas (value relevance, disclosure, regulação, etc), representando um dos principais pontos de discussão no meio acadêmico e profissional da área contábil. Cabe ressaltar, ainda, que os modelos teóricos e operacionais têm sido usados freqüentemente nas recentes pesquisas contábeis internacionais e brasileiras, porém é dada pouca atenção à acurácia dos diferentes modelos utilizados. Este trabalho, portanto, se concentra mais na discussão sobre os modelos existentes para estimação dos accruals do que no gerenciamento de resultados por si mesmo.

Healy (1996, p.112) relata que os participantes da Journal of Accounting Research Conference - 1996 'Studies on Recognition, Measurement and Disclosure Issues in Accounting', diante das dificuldades apresentadas pelos trabalhos até aquele momento, sugeriram que as futuras pesquisas focassem, prioritariamente, no estabelecimento de modelos, para que se possa examinar a confiabilidade das evidências apresentadas pelas pesquisas sobre gerenciamento de resultados. Entretanto, passada uma década desde então, os modelos operacionais ainda continuam sendo questionados com relação à sua especificação e eficiência na separação dos componentes dos accruals.

Este estudo busca contribuir para a reflexão e discussão sobre a qualidade dos números contábeis, em particular sobre a discricionariedade dos administradores, melhorando a compreensibilidade sobre os fatores endógenos e exógenos que influenciam as demonstrações 
contábeis e, conseqüentemente, a avaliação empresarial e as relações contratuais das empresas.

Entretanto, Watts e Zimmerman (1986, p.10) alertam que não se pode encontrar uma teoria que possa explicar e predizer todos os fenômenos econômicos, pois o modelo contábil é uma simplificação da realidade. Fatores particulares em determinados subconjuntos de observações são ignorados e não são incorporados às suposições da teoria, gerando o que é denominado, na análise estatística, de omissão de variáveis relevantes.

Mas, o pesquisador não deve abandonar a teoria, pura e simplesmente, porque ela não explica perfeitamente a realidade. Em certos casos, os erros de predição são importantes porque podem conduzir a outros estudos que forneçam novas suposições, sugerindo outros meios para uma teoria mais bem desenvolvida, ou mesmo, apresentem caminhos para uma teoria completamente nova.

\subsection{Organização do Trabalho}

O restante deste trabalho está estruturado da seguinte forma. Nesse capítulo, ainda são apresentados: o problema e objeto de estudo, a formulação da hipótese, objetivos geral e específicos e contribuições deste trabalho. No capítulo 2, uma revisão de literatura é efetuada sobre a informação contábil e sua importância na avaliação do desempenho empresarial e no estabelecimento das relações contratuais. Discute-se o papel da Contabilidade na redução da assimetria informacional e na resolução dos problemas de agência, seleção adversa e risco moral, bem como as influências dos fatores institucionais e organizacionais em suas atividades.

Especificamente na seção 2.3, tratam-se as características e conseqüências da Qualidade das Informações Contábeis. A seção 2.4 apresenta a discricionariedade dos administradores em relação às perspectivas oportunística e de eficiência das informações contábeis, bem como conceitos, características, incentivos para a tal prática. Discute-se também a classificação das formas e padrões de manipulação das informações contábeis.

Na seção 2.5, discute-se o processo de desenvolvimento e de validação dos modelos teóricos e operacionais na pesquisa analítico-empírica.

No capítulo 3, efetua-se uma análise teórico-crítica sobre os modelos operacionais que buscam identificar o componente gerenciado dos resultados contábeis. Inicialmente, discute- 
se a relação entre resultados, fluxo de caixa e accruals (seção 3.1.) e a forma de estimação dos accruals totais (seção 3.2). Nas seções seguintes, são apresentados e analisados os modelos existentes na literatura corrente para a detecção de gerenciamento de resultados através dos accruals e atividades operacionais. No final desse capítulo, é apresentado um modelo operacional proposto para identificar o componente gerenciado dos resultados através dos accruals e atividades operacionais no contexto brasileiro.

Os procedimentos metodológicos são apresentados no capítulo 4, no qual são definidas as hipóteses estatísticas desta pesquisa, o plano amostral, os testes empíricos para especificação e poder estatístico dos modelos concorrentes.

No capítulo 5, efetua-se uma análise descritiva dos dados da amostra e desenvolve-se os testes estatísticos para avaliar o grau de ajuste dos modelos concorrentes nos vários ambientes econômicos. Por fim, ajuste-se o modelo proposto diante das novas evidências empíricas.

As considerações finais do trabalho e sugestões para os futuros trabalhos são apresentadas no capítulo 6.

\subsection{Problema e Objeto de Estudo e Formulação da Hipótese}

O ponto inicial para um projeto de pesquisa é que a questão a ser explorada seja de interesse e de potencial importância para o meio científico e profissional e para a sociedade.

Tendo em vista o crescente número de pesquisas empíricas baseadas nos modelos propostos em ambientes econômicos e institucionais diferentes do contexto brasileiro e a preocupação com a validação teórica e empírica das evidências apresentadas, em particular, sobre a identificação de ações discricionárias por parte dos gestores, este estudo visa responder ao seguinte problema de pesquisa:

\section{Os modelos propostos na literatura corrente para a estimar os accruals discricionários utilizados na deteç̧ão de gerenciamento de resultados contábeis têm validação teórica e empírica para avaliar adequadamente a discricionariedade dos gestores?}

Diante da exposição do problema, torna-se importante enunciar as hipóteses metodológicas que o trabalho se propõe a analisar. Segundo Severino (2002, p.161), a hipótese de pesquisa representa o que se pretende demonstrar e sua formulação leva em consideração o quadro 
teórico no qual se apóia o raciocínio. Entre as diversas funções da formulação das hipóteses destacam-se o papel de orientar o desenvolvimento do estudo, identificar fatores relevantes e não-relevantes, fornecer uma estrutura para organizar as conclusões da pesquisa (COOPER; SCHINDLER, 2003, p.59). Cozby (2003, p.30) ressalta que a hipótese é somente uma idéia preliminar, à espera de evidências favoráveis ou contrárias.

Neste estudo tem-se a seguinte hipótese de pesquisa:

Os modelos teóricos e operacionais constantes da literatura para estimar os accruals discricionários utilizados na deteç̧ão de gerenciamento de resultados contábeis apresentam validade teórica e empírica para avaliar o comportamento discricionário dos gestores.

\subsection{Objetivos}

Em decorrência da descrição do problema e do objeto de estudo e da formulação da hipótese de pesquisa, os objetivos, geral e específicos, apresentam-se a seguir:

\subsubsection{Objetivo Geral}

Este trabalho tem como objetivo geral verificar a validade teórica e empírica dos modelos operacionais para mensurar os accruals discricionários utilizados na detecção de gerenciamento de resultados contábeis, com a finalidade de apresentar um modelo que possa contribuir para redução de problemas relacionados as evidências empíricas.

\subsubsection{Objetivos Específicos}

Para atender ao objetivo geral deste estudo, têm-se os seguintes objetivos específicos:

a) Avaliar os modelos analítico-empíricos de detecção de gerenciamento de resultados contábeis por meio da fundamentação teórica subjacente;

b) Avaliar os modelos analítico-empíricos de mensuração dos accruals totais e a decomposição dos accruals em componentes discricionários e não-discricionários; 
c) Verificar a especificação e o poder estatístico dos modelos existentes para a estimação dos accruals discricionários utilizados na detecção de gerenciamento de resultados contábeis;

d) Identificar os fatores endógenos e exógenos presentes nas informações contábeis e que afetam a mensuração dos accruals discricionários e, conseqüentemente, influenciam a especificação e a eficiência dos modelos de detecção de gerenciamento de resultados contábeis;

e) Propor modelo de mensuração dos accruals discricionários para detecção de gerenciamento de resultados contábeis em face dos outros fatores relevantes no processo de mensuração dos accruals totais;

f) Comparar a eficiência do modelo proposto em relação aos demais modelos dentro contexto brasileiro, norte-americano e outros países da América Latina.

\subsection{Contribuições}

As contribuições deste trabalho podem ser classificadas em teóricas, metodológicas e empíricas. Entre as contribuições teóricas, destacam-se:

a) A análise crítica sobre a fundamentação teórica no desenvolvimento do modelo geral utilizado para a detecção do gerenciamento de resultados contábeis,

b) O desenvolvimento e apresentação de uma especificação de modelo mais abrangente para a detecção do gerenciamento de resultados contábeis, que analisa simultaneamente dois ou mais incentivos e incorpora os custos associados às práticas discricionárias;

c) A análise crítica sobre a especificação dos modelos operacionais que estimam os accruals discricionários utilizados na detecção de gerenciamento de resultados através das escolhas contábeis;

d) A proposição de um novo modelo para a estimação dos accruals discricionários utilizados na detecção de gerenciamento de resultados através das escolhas contábeis;

e) A incorporação ao modelo proposto de caracteríticas e fatores que afetam o comportamento dos accruals totais, como: conservadorismo, relação não-linear entre os incentivos e os accruals discricionários, controle do desempenho extremo de resultados e fluxos de caixa;

f) A incorporação ao modelo proposto de proxies de gerenciamento de resultados por meio das atividades operacionais. 
Com relação às contribuições metodológicas, têm-se:

a) A análise empírica dos modelos com base em uma amostra composta com os maiores mercados de capitais do continente americano: Brasil, Chile, México, Peru e Estados Unidos da América;

b) Utilização de informações contábeis compreendendo um período de tempo de10 (dez) anos (1996 a 2005), o que auxilia nas estimações de parâmetros e testes estatísticos mais robustos;

c) Emprego de vários procedimentos e métricas para avaliar as inferências estatísticas, a especificação e o poder preditivo dos modelos analisados, entre as quais se destacam: o teste Vuong e a Simulação de Monte Carlo, que possuem maior robustez, mas que praticamente não são utilizados nas pesquisas contábeis;

d) Utilização da abordagem positiva e normativa para analisar um determinado fenômeno contábil;

e) Desenvolvimento de pesquisa analítico-empírica no ambiente acadêmico brasileiro.

Por fim, como as principais contribuições empíricas, têm-se:

a) Comprova as relações entre os accruals contábeis, resultados contábeis e fluxo de caixa operacional;

b) Evidencia que os pesquisadores devem utilizar alguma proxy para controlar o nível de conservadorismo em ambientes econômicos em que existam níveis de comportamento conservador significativamente diferentes entre as empresas ou grupos de empresas e, principalmente, em pesquisas que versem sobre as diferenças das caraterísticas das informações contábeis entre os diversos países;

c) Apresenta evidências de que os modelos operacionais presentes na literatura têm baixo poder preditivo para avaliar o comportamento dos accruals discricionários;

d) Apresenta evidências de que os modelos sofrem variações em seu poder preditivo quando avaliados em ambiente distintos;

e) Os resultados comprovam que o modelo proposto neste estudo tem maior poder preditivo para estimar os accruals discricionários em qualquer ambiente analisado neste trabalho. 
Para Watts e Zimmerman (1986, p. 2), "o objetivo da teoria da Contabilidade é explicar e predizer a prática contábil." ${ }^{\mathrm{O}}$ termo 'explicar' refere-se à compreensão do fenômeno observado, analisando os fatores que o influenciam; enquanto o termo 'predizer' refere-se ao entendimento dos fenômenos contábeis não observados, mas, não necessariamente, eventos futuros, pois inclui os já ocorridos mas que não foram sistematicamente observados.

Espera-se que, baseados em pesquisas com metodologias adequadas, os pesquisadores possam desenvolver teorias que expliquem a realidade e auxiliem os usuários da informação contábil na avaliação do desempenho e no estabelecimento das relações contratuais das empresas.

Nas últimas décadas, a pesquisa contábil foi fortemente influenciada pela Teoria Positiva. Scott (2003, p.273) explica que a "Teoria Positiva da Contabilidade está interessada com a predição tais ações em relação às escolhas de políticas contábeis pelos administradores da firma e como os administradores responderão as novas normas contábeis. "”

Iudícibus e Lopes (2004, p.19) acrescentam que "a teoria positiva da contabilidade procura descrever como as empresas decidem que tipo de informação deve divulgar, isto é, de que maneira selecionam os procedimentos contábeis que utilizam". Assim, a Teoria Positiva da Contabilidade busca descrever a realidade, explicar o passado e possibilitar a previsão de ocorrência ou não de determinados fenômenos no futuro, não entrando no mérito sobre quais seriam as melhores práticas ou procedimentos contábeis a serem utilizados pelos contadores.

A Teoria Normativa visa recomendar como as informações contábeis devem ser mensuradas e evidenciadas, ou seja, "procuram explicar o que deve ser, em lugar do que é." (HENDRICKEN; VAN BREDA, 1999, p. 30).

A dicotomia Normativismo vs Positivismo na pesquisa contábil pode conduzir a abordagens distintas de alguns conceitos da Contabilidade. Eliseu Martins (2005, p.3), no editorial da Revista Contabilidade \& Finanças USP n ${ }^{\circ}$ 39, exemplifica esse fato, relatando que o conceito de conservadorismo para os normativistas está ligado à necessidade de maior credibilidade às demonstrações contábeis, enquanto para os positivistas é considerada basicamente como responsável pelo reconhecimento assimétrico dos resultados contábeis.

\footnotetext{
${ }^{6}$ Tradução livre de: "The objective of accounting theory is to explain and predict accounting practice"

${ }^{7}$ Tradução livre de: "Positive accounting theory (PAT) is concerned with predicting such actions as the choices of accounting policies by firm managers and how managers will respond to proposed new accounting standards."
} 
Em termos de produção científica, é visível o crescimento do Positivismo Contábil no contexto internacional e nacional, e, cada vez mais, os principais veículos de publicação de pesquisas contábeis têm privilegiado esse tipo de pesquisa.

O fato é que alguns dos trabalhos publicados na linha positiva têm seu maior mérito no procedimento empírico utilizado do que nos conceitos contábeis empregados ou na sua importância para o meio acadêmico, profissional e para a sociedade. A conseqüência é que a pesquisa normativa tem sido deixada em segundo plano pela 'mídia' acadêmica, o que, conseqüentemente, tem gerado um processo 'invisível' de inibição de trabalhos criativos e inovadores em Contabilidade Normativa. Assim, Eliseu Martins (2005, p.3) defende o equilíbrio dessas linhas, aproveitando as qualidades da Pesquisa Normativa e Positiva na Contabilidade:

Quem sabe ainda tenhamos mais pesquisas e provas por parte dos Positivistas do que os usuários de fato precisam e querem (na Contabilidade Financeira - Geral e na Gerencial), e como isso consigamos direcionar a mente e a criatividade dos pesquisadores Normativistas para produzirem essas respostas, a serem testadas pelos Positivistas, que gerarão novas demandas para os Normativistas etc.

Portanto, a Teoria Normativa, através da sua consistência lógica dos pressupostos, contribui juntamente com a Teoria Positiva para o desenvolvimento do conhecimento contábil e ampliação das pesquisas empíricas na área contábil.

Basicamente comum às duas abordagens de pesquisa, o objetivo primário da Contabilidade é prestar informações relevantes sobre as entidades para seus diversos usuários, sendo que a maioria deles é externa. O produto da Contabilidade é a informação, que se caracteriza pela sua utilidade e complexidade.

Adicionalmente, deve considerar o método fenomenológico, em que o conhecimento se obtém pela compreensão das características essenciais de todo e qualquer fenômeno que se manisfeste à consciência e a experiência aplicável ao fenômeno ocorre por meio da vivência fenomenologia descritiva; bem como se propõe a interpretar a percepção dos fenômenos, buscando o conhecimento por meio de interpretação - fenomenologia hermenêutica (THEÓPHILO, 2004, p.61-68). Entretanto, Theóphilo (2004, p.65) observa que a produção científica da fenomenologia é considerada incipiente.

Traçando um paralelo entre os objetivos da Contabilidade e da Economia, Demski (2005, p.1) afirma que, de modo geral, a "Economia é preocupada com a produção e alocação dos recursos e a Contabilidade é preocupada com a mensuração e evidenciação sobre a 
produção e alocação dos recursos." ${ }^{\prime 8} \mathrm{O}$ mesmo autor ainda considera que a Contabilidade, por si só, é um processo produtivo e tem produção e alocação de recursos, dando uma conotação de que a informação contábil (produto da Contabilidade) é um bem econômico. Para RiahiBelkaoui (2000, p.63), a “Contabilidade também é observada como um commodity que resulta de uma atividade econômica", pois a informação contábil é demandada pelo mercado. Logo, sendo produtor de um bem de interesse público, sugere-se que a Contabilidade ofereça fundamentos para sua regulação.

A informação contábil influencia as decisões individuais de seus usuários, afetando a alocação dos recursos e o funcionamento dos mercados, conseqüentemente, a eficiência da economia. Iudícibus (2004, p.25), afirma que "o objetivo básico da contabilidade, [...] pode ser resumido no fornecimento de informações econômicas para vários usuários, de forma que propiciem decisões racionais".

Entretanto, a Contabilidade é uma atividade econômica complexa, pois opera em um ambiente sob condições de incertezas. A complexidade justifica-se pelo fato de os seus usuários não exercerem reações homogêneas diante da mesma informação contábil. Scott (2003, p.6) afirma que um investidor sofisticado pode reagir positivamente à mensuração dos ativos ao fair value, pois essa auxiliará na predição do desempenho futuro da companhia; enquanto outros investidores podem reagir negativamente, considerando que os números contábeis divulgados não são confiáveis ou pelo simples fato de que seu processo decisório está baseado no custo histórico. Assim, o ambiente da Contabilidade, complexo e dinâmico, é também caracterizado pelo conflito entre as pressões exercidas pelos diferentes grupos de interessados na informação.

A Teoria da Agência tem auxiliado a Contabilidade a compreender mais claramente os objetivos das pressões direcionadas ao processo de regulação contábil e os efeitos da informação contábil na alocação dos recursos.

Para Jensen e Mecking (1976. p.8), as firmas são "suposições legais para qual servem como nexo para um conjunto de relações contratuais entre individuos." ${ }^{10}$ Assim, a empresa é vista como um conjunto de contratos entre os diversos participantes, como, por exemplo, acionistas, administradores, empregados, fornecedores, clientes, governos, entre outros; e cada participante contribui com algo para a firma e em troca recebe sua parte do 'bolo'. O

\footnotetext{
${ }^{8}$ Tradução livre de: “[...], economics is concerned with production and allocation of resources and accounting is concerned with measuring and allocation on the production and allocation of resources."

${ }^{9}$ Tradução livre de: "Accounting is also viewed as a commodity that results from an economic activity."

${ }^{10}$ Tradução livre de: "legal fictions which serve as a nexus for a set of contracting relationships among individuals."
} 
objetivo da firma é a redução dos diversos custos associados aos contratos, sendo que seu funcionamento depende do equilíbrio contratual estabelecido, podendo ser prejudicado ou interrompido se alguma das partes estiver insatisfeita. (LOPES; MARTINS, 2005, p.32-33).

Muitos desses contratos envolvem variáveis contábeis, como, por exemplo, a remuneração dos gestores quando baseado no desempenho econômico da empresa ou os credores que podem demandar proteção do capital emprestado através da manutenção de certos indicadores financeiros. Assim, a informação contábil, observada pela ótica dos custos de contratos, tem o papel de auxiliar no monitoramento e cumprimento dos contratos para reduzir os custos da agência de certos conflitos de interesses.

Os problemas de agência geram custos aos principais, representado através de custos com monitoramento, bonificação aos agentes e outras perdas residuais (SCHROEDER et al, 2001, p.49). Os custos com monitoramento são os gastos efetuados pelo principal para controlar o comportamento do agente, como, por exemplo, os gastos com auditores externos. Os custos com bonificação referem-se, geralmente, aos gastos com a remuneração do agente para que ele desempenhe ações conforme o interesse do principal. As perdas residuais ocorrem quando as ações adotadas pelo agente diferem daquelas que seriam praticadas pelo principal, tendo essa divergência efeito sobre a riqueza do principal.

A Teoria da Agência assegura que os indivíduos atuam para maximizar suas próprias utilidades, ao ponto que os acionistas esperam incorrer em custos de monitoramento e de bonificação, que devem ser menores do que as perdas residuais.

Bushman e Smith (2001, p.238) definem o papel da informação contábil como mecanismo de controle que promove a governança eficiente das empresas. Mecanismos de controle corporativo referem-se aos meios necessários para que o agente (administrador) atue em pleno interesse do principal (acionistas). Esses mecanismos podem ser classificados em internos (por exemplo, planos de incentivos, monitoramento gerencial e mercado de trabalho interno) ou externos (monitoramento pelos acionistas, credores e órgãos reguladores, legislação do mercado de capitais, entre outros). Para Sloan (2001, p. 336), sem os problemas de governança, o papel da Contabilidade seria reduzido em fornecer informações de risco e retorno aos investidores, para que eles possam alocar otimamente seus recursos.

Considera-se que o preço que um indivíduo estaria disposto a pagar pela aquisição de uma informação dependerá dos benefícios proporcionados por ela. Nicholson (2002, p.229) argumenta que "existem muitas razões para acreditar que os custos das informações diferem 
significativamente entre os indivíduos." "11, ocasionando em diferentes níveis de informação entre os participantes do mercado, ou seja, a assimetria de informações. A Contabilidade auxilia na moderação dos problemas de agência, à medida que busca reduzir a assimetria informacional entre o agente e o principal.

A assimetria informacional pode conduzir a dois fenômenos: seleção adversa e risco moral. Pindyck e Rubinfeld (2006, p.532) conceituam o problema da seleção adversa como uma "forma de falha de mercado que ocorre quando, devido a informações assimétricas, produtos de diferentes qualidades são vendidos a um preço único; dessa maneira, vendem-se inúmeros produtos de baixa qualidade e pouquíssimos de alta qualidade." Mas-Colell et al (1995, p.440) explica que esse tipo de problema ocorre quando "a decisão de negociação do indivíduo informado depende das suas características não observadas de uma maneira que, adversamente, afeta os agentes não informados no mercado. ",12

Portanto, a seleção adversa surge quando um agente utiliza informações privadas e não observáveis para atuar de forma oportunística e o principal não seja capaz de verificar se ele agiu segundo interesses próprios.

O risco moral ocorre quando as ações de um determinado agente não podem ser observadas pelo outro lado da relação contratual e, conseqüentemente, afeta a alocação dos recursos disponíveis. Resumidamente, o risco moral é caracterizado como um problema de ação oculta, enquanto a seleção adversa refere-se a problema de informação oculta (MAS-COLELL et al, 1995; SCOTT, 2003).

Considerando a relação da seleção adversa e risco moral, espera-se que, por exemplo, o principal (indivíduo menos informado) procure mais informações para monitorar o comportamento do agente (indivíduo mais informado). Assim, um aumento no nível de informações, conseqüentemente, pode reduzir os custos de capital, em detrimento da elevação de alguns custos contratuais.

Então, para atingir um sistema de governança eficiente torna-se necessário um trade-off entre os custos de capital e custos dos contratos, sendo que o primeiro pode ser reduzido pelas escolhas contábeis que minimizariam a preocupação dos investidores com o problema da seleção adversa. Scott $(2003$, p.107) relata que "nós podemos pensar o relatório financeiro

\footnotetext{
${ }^{11}$ Tradução livre de: "[...], there are many reasons to believe that information costs may differ significantly among individuals. ”

${ }^{12}$ Tradução livre de: "[...] an informed individual's trading decision depends on her unobservable characteristics in a manner that adversely affects the uninformed agents in the market."
} 
como um instrumento para reduzir o problema da seleção adversa, relacionado à melhora da operação do mercado de capitais e reduzindo a imperfeição."13

Uma maneira teoricamente possível para minimizar a seleção adversa é a adoção de políticas de full disclosure, pois o aumento do volume de informações disponíveis e ajustes no momento (oportunidade) da divulgação das informações reduzem a capacidade dos insiders em obter maiores lucros baseados em informações privilegiadas. Mas, como exposto anteriormente, qualquer informação, incluindo a oriunda da Contabilidade, possui custos para sua obtenção, o que dificulta a eliminação total dos problemas da agência.

Outras formas de reduzir os problemas de seleção adversa e risco moral seriam através da regulamentação e da sinalização. As entidades governamentais ou de representação de classe podem regular o funcionamento de algumas atividades da Contabilidade, em particular, determinando parâmetros de mensuração e evidenciação das informações contábeis, inclusive estabelecendo penalidades para aqueles que não cumprirem suas determinações.

Para Scott (2003, p.412), o principal argumento em favor da regulação da Contabilidade é o de proteger os indivíduos que estariam em desvantagens informacionais dentro de um determinado mercado. Lopes e Martins (2005, p.85) afirmam que:

Os argumentos que favorecem a regulamentação da contabilidade são, em sua maior parte, baseados no argumento de que agências governamentais, e outros órgãos similares, possuem vantagens comparativas em relação ao mercado na exigência do fornecimento de informações. Esse argumentos baseiam-se na hipótese de que o mercado livremente não seria capaz de impor uma disciplina adequada para a evidenciação pública das informações; nesse cenário, investidores minoritários e outros agentes menos favorecidos, como sindicatos, seriam penalizados.

Os autores (2005, p.85) advertem que "não existem evidências empíricas claras a esse respeito", e citam o exemplo do Reino Unido, "que permanceram durante grande parte do século XX, absolutamente livres de influência governamental", o que contraria a hipótese apresentada anteriormente.

Por outro lado, o próprio mercado pode fornecer incentivos para que a insider information seja revelada publicamente, mesmo sem a presença de penalidades, como, por exemplo, quando a administração deseja sinalizar aos seus potenciais investidores sobre as oportunidades econômicas em investir na empresa. $\mathrm{O}$ valor de mercado da firma é uma função da percepção dos agentes econômicos que pode ser influenciada pela capacidade dos administradores em antecipar as mudanças futuras no ambiente econômico e quanto antes os investidores inferirem sobre o futuro da empresa, mais favorável a eles reage a antecipação da informação.

\footnotetext{
${ }^{13}$ Tradução livre de: "We can think of financial reporting as a device to reduce the adverse selection problem, thereby improving the operation of securities markets and reducing incompleteness."
} 
Enquanto os administradores desejam maior flexibilidade de julgamento para efetivamente comunicar suas informações aos usuários das demonstrações contábeis, os reguladores da Contabilidade buscam limitar as oportunidades de os gestores apresentarem números não condizentes com a realidade econômica e financeira. Assim, Verrecchia (2001, p.143) considera que a verdadeira informação contábil é justificada pelo interesse de evitar potenciais gastos de litígios associados à dissimulação da realidade empresarial.

Em outros estudos, a Contabilidade é considerada como meio importante pelo qual a empresa busca responder às pressões ambientais e estabelecer sua legitimidade (POTTER, 2005, p.270). Nesse sentido, as empresas adotam práticas e procedimentos contábeis como meio de organização e monitoramento de suas atividades, com o intuito de transmitir credibilidade às ações dos gestores da empresa.

Para Beaver (1998, p.13), os relatórios contábeis têm diversas conseqüências econômicas que afetam, por exemplo:

a) a distribuição da riqueza entre os indivíduos;

b) o risco agregado ocorrido e a alocação dos riscos entre os indivíduos;

c) o consumo agregado e a produção agregada;

d) a alocação de recursos entre as firmas;

e) o uso dos recursos destinados para à: produção, certificação, disseminação, processamento, análise e interpretação da informação publicamente disponível;

f) o uso dos recursos no desenvolvimento, conformidade (compliance), execução (enforcement) e processos de regulação e

g) a busca de informações privadas.

Diante das várias conseqüências econômicas das informações prestadas pela Contabilidade aos diversos usuários, pode-se considerar a escolha das práticas a serem observadas no sistema contábil como uma escolha social, sendo um trade-off entre os agentes econômicos em um processo político. Zeff $(1978$, p. 56) define a conseqüência econômica como “o impacto dos relatórios contábeis sobre o comportamento da tomada de decisão dos negócios, governo, sindicato, investidores e credores" ${ }^{14}$, sendo que o comportamento de um indivíduo ou grupo pode estar em conflito com interesse de outros agentes. Assim, Scott (2003, p.259) afirma que, apesar das implicações da teoria do mercado eficiente, a escolha da política contábil pode afetar o valor da firma.

\footnotetext{
${ }^{14}$ Tradução livre de: "[...] the impact of accounting reports on the decision-making behavior of business, government, unions, investors and creditors."
} 
Watts e Zimmerman (1986, p. 3) asseguram que, no momento de decidir sobre como reportar as informações contábeis, os indivíduos procuram conhecer como as alternativas de mensuração e evidenciação afetam suas riquezas. Entretanto, os efeitos das escolhas contábeis sobre a riqueza dos indivíduos são complexos e podem não ser integralmente determinados pela mera observação.

Com características idiossincráticas em cada ambiente econômico, a natureza e extensão dos mecanismos de governança diferem amplamente entre os países e companhias. Devido à má conduta empresarial e às fraudes praticadas por grandes corporações nos últimos tempos, utilizando as informações contábeis como instrumento para tal comportamento, tem-se colocado em situação delicada a confiabilidade sobre os relatórios contábeis, verificando se um aumento de pesquisas desse tema em diferentes ambientes econômico, social e político.

Essa preocupação com a fidedignidade sobre a Contabilidade é justificada, pois a avaliação do desempenho empresarial influencia a decisão de alocação dos recursos. Entretanto, entende-se que essa tarefa é demasiadamente complexa, pois o indivíduo que busca analisar as demonstrações contábeis e outros relatórios financeiros necessita compreender o ambiente empresarial e contábil em que a empresa está inserida (MARTINS, Eliseu, 2005a; 2005b).

\subsection{Escolhas contábeis e os fatores institucionais e organizacionais}

As informações contábeis são demandadas devido à assimetria informacional e aos problemas de agência. Dentro desse cenário, as pesquisas sob a abordagem positiva da Contabilidade testam as hipóteses levantadas sobre duas perspectivas: oportunística e eficiência (BEAVER, 1998; SCOTT, 2003; IUDÍCIBUS e LOPES, 2004).

A perspectiva oportunística assume que os administradores escolhem políticas contábeis para maximizar suas próprias utilidades esperadas relativas a determinada relação de remuneração, contratos de dívidas e custos políticos. Scott (2003, p.283-285) explica que essas hipóteses podem ser analisadas pela perspectiva de eficiência, observando que contratos de remuneração e o sistema de controle interno (inclui o monitoramento por partes dos conselhos internos) limitam a atuação oportunística dos gestores, motivando-os a escolherem procedimentos contábeis que reduzam os custos de capital e custos contratuais e minimizem o risco da firma. 
Porém, torna-se muito difícil a separação das políticas contábeis utilizadas sob a perspectiva oportunística ou de eficiência, o que prejudica em parte as inferências sobre os resultados evidenciados nas pesquisas.

Na perspectiva oportunística, Watts e Zimmerman (1990, p. 138) apresentam três hipóteses principais:

a) Hipótese do plano de bônus (bonus plan hypothesis): se todos os demais fatores permanecerem constantes, os administradores preferem escolhas contábeis que antecipem os lucros futuros para o período corrente e, conseqüentemente, sua própria remuneração quando baseada em resultados contábeis;

b) Hipótese de cláusulas contratuais de dívidas (debt covenant hypothesis): quando a firma tem contratos com restrições de desempenho econômico e financeiro baseados em números da Contabilidade, o administrador poderá utilizar procedimentos contábeis que evite a violação de cláusulas contratuais e, normalmente, antecipa os resultados positivos futuros para o período corrente para reduzir a possibilidade de um default técnico;

c) Hipótese dos custos políticos (political cost hypothesis): diante dos diversos custos políticos da firma, o administrador pode preferir políticas contábeis que posterguem o reconhecimento de lucros correntes para períodos futuros.

Cabe salientar que em relação à primeira hipótese, se o administrador tem aversão ao risco, ele preferirá critérios contábeis que 'suavizem' a variação dos resultados, evitando a volatilidade dos preços das ações, desde que o valor presente do bônus seja maior.

Uma possibilidade de aumento dos custos políticos é quando as empresas apresentam um elevado nível de lucratividade, atraindo a atenção dos demais agentes. Como, por exemplo, o governo poderá estabelecer um aumento de carga tributária ou uma regulamentação mais rígida para evitar abusos econômicos, ou de sindicatos dos trabalhadores que, com base na informação de aumento dos lucros da empresa, buscam auferir melhores remunerações e condições de trabalho para os seus afiliados.

Portanto, as informações contábeis reportadas são afetadas pelos incentivos associados ao plano de remuneração, contratos de dívidas e custos políticos, o que influencia o processo das escolhas contábeis.

Adicionalmente, a informação contábil é influenciada pela existência de critérios alternativos de mensuração e evidenciação, fazendo com que o administrador possa escolher dentre as 
normas e práticas permitidas pela regulamentação contábil, quando essa existir ${ }^{15}$. Fields et al (2001) descrevem que a natureza das escolhas contábeis inclui:

a) escolha entre regras igualmente aceitas;

b) julgamentos e estimativas requeridas por alguns sistemas contábeis;

c) decisões de estratégias de disclosure;

d) decisões do momento do reconhecimento e

e) atividades de lobby.

Isso possibilita que os administradores escolham alternativas válidas com o objetivo de apresentarem informações da forma desejada, impactando no desempenho econômico ou na estrutura financeira da empresa (FIELDS et al, 2001; FRANCIS, 2001). Portanto, a Contabilidade pode apresentar dificuldades em atingir os seus objetivos, em especial, a diminuição da assimetria informacional em certos ambientes institucionais e organizacionais. Mas, para Scott (2003, p.107), mesmo que os preços dos títulos no mercado reflitam totalmente toda a informação publicamente disponível, ainda provavelmente os insiders sabem mais do que os outsiders sobre a verdadeira qualidade da firma.

As escolhas contábeis têm conseqüências econômicas se as mudanças nos procedimentos adotados para mensurar e evidenciar as informações contábeis influenciarem na riqueza dos agentes econômicos que utilizam os números contábeis para contratação e tomada de decisões (HOLTHAUSEN; LEFTWICH, 1983, p.77).

Schroeder et al (2001, p.19) consideram que as escolhas contábeis podem ser classificadas em dois níveis de competência: (1) órgãos reguladores e (2) empresa. Os órgãos reguladores têm o poder de exigir que as empresas evidenciem as informações contábeis de uma determinada maneira ou proibir a utilização de um determinado método de mensuração e/ou evidenciação considerado indesejado. No segundo nível, as empresas escolhem um determinado procedimento dentro das alternativas permitidas pelos órgãos reguladores. Cabe lembrar que a teoria contábil preconiza a escolha do critério de mensuração e/ou evidenciação que produza a melhor informação contábil.

Adicionalmente, as escolhas contábeis são conduzidas por um amplo conjunto de fatores que afetam os números contábeis e algumas delas possuem efeitos imediatos e/ou de longo prazo nos resultados, outras escolhas afetam somente componentes do resultado dentro do período.

\footnotetext{
15 Podem ocorrer situações em que determinado evento ou transação econômica ainda não tenha norma especifica. Nesse caso, normalmente, as empresas buscam normas que especifiquem um outro evento ou transação semelhante àquele em que se está mensurando ou evidenciando.
} 
Sob a ótica da Teoria da Agência, observa-se que as informações contábeis são influenciadas diretamente pelos interesses pessoais dos agentes ou principais (WATTS; ZIMMERMAN, 1986, BEAVER, 1998; SCOTT, 2003; LOPES; MARTINS, 2005). Esses interesses podem ser afetados pelos mecanismos de remuneração, acordos contratuais, legislação societária, concorrência, dentre outros. Ball (1999), Ali e Hwang (2000), Sloan (2001) e Giner e Rees (2001) incluem, ainda, outros fatores como fontes de financiamento, legislação tributária, mercado de capitais e estrutura acionária. Devido aos inúmeros fatores e interesses, existe a possibilidade de que a Contabilidade apresente informações contábeis enviesadas da realidade econômica da firma.

Alguns trabalhos teóricos sugerem que a qualidade da informação contábil difere entre as empresas devido à maior dependência do mercado de capital em relação a outras fontes de financiamentos das atividades empresariais, o que influencia o nível de monitoramento do desempenho das companhias através do disclosure (BUSHMAN; SMITH, 2001, p.308).

Com relação à influência do sistema legal sobre as informações contábeis, pode-se considerar que um dos aspectos é a forma como a legislação protege investidores da expropriação dos administradores e acionistas principais da companhia. Sugere-se que os investidores com um melhor nível de informação terão melhores condições de alocar eficientemente os seus recursos, minimizando a possibilidade de ações discricionárias dos administradores.

Bushman e Smith (2001, p. 298) comentam que as pesquisas empíricas apresentam evidências de que a proteção aos investidores da expropriação dos insiders (administradores e principais acionistas) tem afetado significativamente o desenvolvimento e a eficiência do mercado de capitais. Assim, o custo de capital e o desempenho econômico e financeiro das companhias também são afetados por essas ações discricionárias dos gestores.

Para Pope e Walker (1999, p.54), as diferenças no conteúdo informacional têm sido associadas com as características institucionais e com mercado de capitais que, possivelmente, implique em diferenças nos atributos fundamentais da mensuração contábil. O conteúdo informacional dos números contábeis é de difícil mensuração porque o verdadeiro desempenho econômico não é observado (BURGSTAHLER et al, 2006, p. 984).

Corroborando as pesquisas anteriores, Choi et al (1999, p. 29-31) e Weffort (2005, p.42) apontam diversos fatores institucionais que afetam a informação contábil diferentemente em relação a outros países, dentre os quais se destacam: sistema de financiamento dos negócios, concentração do controle acionário, inflação, sistema jurídico e sistema fiscal

Choi et al (1999, p. 30) consideram que, nos países em que a principal fonte de recursos para financiamento das atividades empresarias é o mercado de capitais, como, por exemplo, 
Estados Unidos da América e Reino Unido, as informações contábeis elaboradas pelas empresas buscam, principalmente, auxiliar os investidores a estimar e avaliar os fluxos de caixa futuros. Por outro lado, nos países em que o mercado de crédito é a principal fonte de captação de recursos das empresas, o sistema contábil é direcionado para a proteção ao credor. Para Niyama (2005, p.27), apesar de não possuir um mercado de capitais considerado sólido e atuante, o Brasil incorporou muitas das práticas contábeis empregadas nos mercados de capitais mais desenvolvidos as quais têm a maior preocupação de prestar informações aos acionistas e não aos credores. Assim, os relatórios contábeis das empresas brasileiras não são exatamente para atender aos bancos e ao governo.

O grau de concentração de propriedade das empresas influencia na demanda por informações contábeis. Pode-se considera que, em países com maior concentração de controle acionário, as empresas resolvam grande parte dos problemas de conflitos de interesses e assimentria informacional internamente, o que influencia diretamente na qualidade das informações contábeis divulgadas (BALL; SHIVAKUMAR, 2005, p.84). Segundo Grava (2004, p.112116), o controle acionário é concentrado no Brasil, com cerca de $60 \%$ dos votos sob o controle do principal acionista, considerado um percentual elevado para os padrões mundiais, e salta para $90 \%$ quando se considera a presença de acordo dos principais acionistas. Ainda o mesmo autor (2004, p.116) comenta que a concentração do controle é independente do porte da empresa.

Em economias com a presença de hiperinflação existe uma tendência natural de incorporar e aperfeiçoar as práticas contábeis que ajustem os números contábeis a níveis gerais de preço, como ocorreu na Argentina, Brasil, Israel e México. No Brasil, particularmente, adotou-se o sistema de Correção Monetária Integral a partir do final da década de 1980 até meados da década seguinte.

A regulação tributária desempenhada pelo Governo afeta em maior ou menor grau o sistema contábil, na medida em que auxilia na determinação do valor dos tributos a ser arrecadado aos cofres públicos pela firma (SUNDER, 1997, p.176-179). Pode-se considerar que é custoso para o Governo estabelecer um sistema tributário separado do sistema contábil, com isso ele utiliza os números reportados nos relatórios contábeis para atender as suas necessidades de arrecadação e fiscalização tributárias das empresas. O sistema contábil brasileiro não está tão fortemente influenciado pelo sistema tributário, como ocorre na Alemanha e França, mas o Fisco brasileiro, em algumas situações, emite regras tributárias que afetam os procedimentos contábeis adotados pelas empresas (NIYAMA, 2005, p.27-31). Outro ponto a destacar é que o próprio sistema tributário brasileiro diferencia-se de muitos países, pois a sua principal fonte 
de arrecadação são os tributos calculados sobre o valor do faturamento total e não pelo lucro líquido do período (BRASIL, 2006a).

\subsection{A Contabilidade e os intermediários de informação}

Com o objetivo de compreender a complexidade da mensuração e evidenciação da informação contábil, deve-se, ainda, considerar a relevante interação entre o regime contábil e os outros agentes que, direta ou indiretamente, integram o sistema de governança corporativa, como: a auditoria, os analistas financeiros e a impressa financeira (BUSHMAN; SMITH, 2001; HEALY; PALEPU, 2001; PALEPU et al, 2004).

Embora exista interesses comuns entre poupadores que buscam investir seus recursos de modo que obtenham uma taxa de retorno satisfatória e companhias que necessitam de capital para financiar suas atividades, existe uma lacuna de informações entre eles.

Como já foi observado anteriormente, os investidores não têm informação (ou capacidade) para escolher os melhores investimentos, enquanto as empresas usualmente não têm infraestrutura ou know-how para captar diretamente os recursos dos investidores. Por essa razão, investidores e companhias confiam nos intermediários da informação para auxiliá-los na tomada de decisões de investimentos e financiamentos (PALEPU et al, 2004, p.I-15).

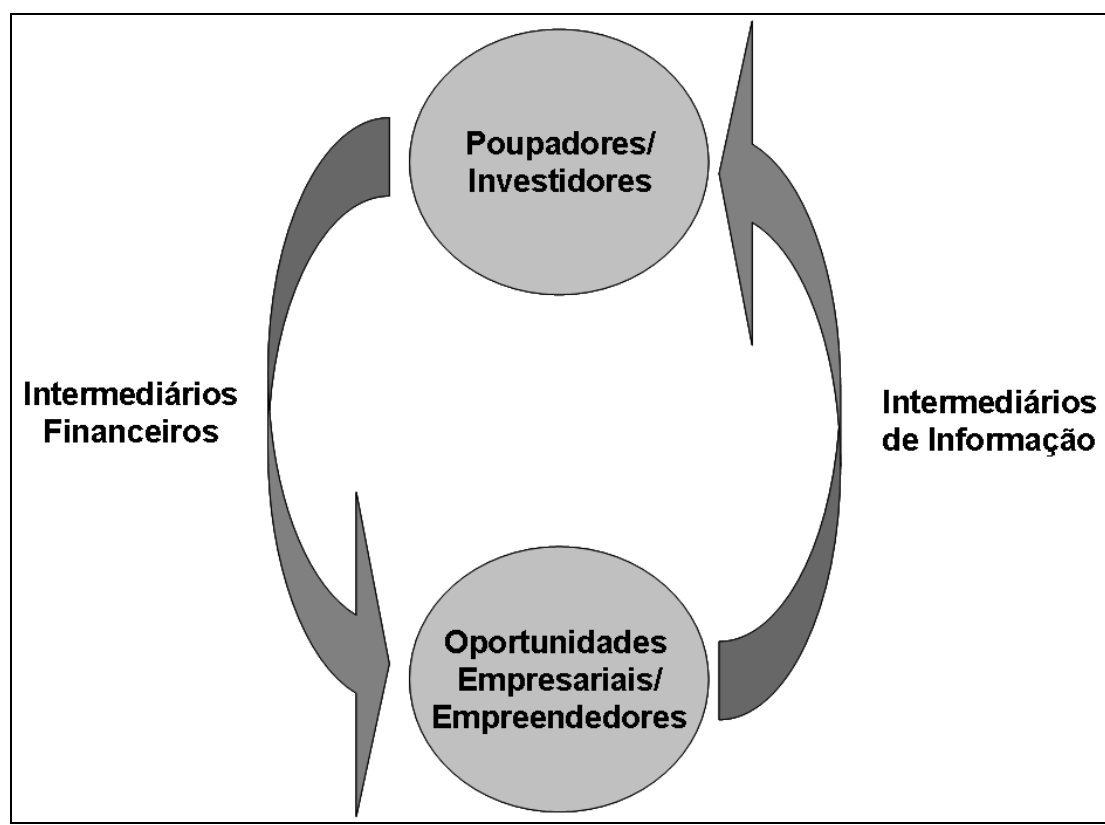

Ilustração 1 - Intermediários da Informação e o mercado de capitais Fonte: Palepu et al, 2004, p.I-2 (adaptado) 
Entre os principais intermediários da informação nos diversos mercados financeiros estão Contabilidade, auditoria independente, órgãos reguladores e/ou fiscalizadores, bancos de investimentos e analistas financeiros.

Dentro do processo comunicação do desempenho das atividades empresariais, existem esses agentes que apresentam outros conjuntos de informações sobre a qualidade da empresa e de seus gestores, contribuindo para a avaliação e/ou tomada de decisão de seus usuários. Assim como a Contabilidade, os demais intermediários da informação auxiliam na redução da assimetria informacional e, portanto, têm um papel relevante no sistema de governança corporativa e na eficiência do mercado de capitais.

$\mathrm{O}$ rápido ajuste nos preços devido à informação sobre perspectivas futuras dos ativos implica que ela é adquirida por pelo menos um participante do mercado. A aquisição dessa informação é obtida por alguns dos intermediários da informação que se especializa em coletá-la e interpretá-la. (SUNDER, 1997, p.85-86).

Um dos principais atributos para qualquer intermediário da informação em um mercado de capitais desenvolvido é a característica fiduciária atribuída pelos demais agentes econômicos sobre os seus trabalhos realizados.

Como exemplo, tem-se a Arthur Andersen, uma das maiores empresas de auditoria no mundo, que durante as investigações sobre no escândalo da Enron, em 2001, foi comprovada a sua participação na destruição de papéis referentes aos contratos de parceiras em prestações de serviços que, supostamente, indicavam procedimentos utilizados pela Enron para esconder as dívidas e inflar os lucros contábeis. Diante de divulgação do seu envolvimento com a Enron, a Arthur Andersen perdeu sua credibilidade junto ao mercado e, conseqüentemente, encerrou suas atividades no dia 30 de agosto de 2002.

Beaver (1998, p. 10) apresenta 03 atividades exercidas pelos intermediários da informação:

a) Busca pela informação privada: refere-se à procura por informações que não estão publicamente disponíveis.

b) Análise prospectiva: refere-se ao processamento, análise e interpretação da informação para predição.

c) Análise retrospectiva: refere-se à interpretação de eventos depois do fato ocorrido.

Os auditores examinam as demonstrações contábeis da empresa, com o objetivo de verificar se elas foram elaboradas em conformidade com as normas contábeis estabelecidas pelos órgãos reguladores e se representam a realidade econômica da firma. Existe um consenso de que os benefícios econômicos das informações contábeis aumentam quando são auditadas, 
pois se acredita, a priori, que estão menos sujeitas a distorções do que aquelas que não foram examinadas pelos auditores. Conseqüentemente, espera-se que as demonstrações contábeis auditadas apresentem melhor conteúdo informacional, por exemplo, para a predição dos fluxos de caixa futuro, identificação de oportunidade e riscos de negócios e diminuição de ações discricionárias dos administradores, o que levaria à redução da seleção adversa entre os investidores. Tais benefícios são esperados quando existe um meio de comunicação mais rápido e menos oneroso para os agentes econômicos sobre as atividades desempenhadas pelos gestores e resultados obtidos pela companhia.

Os efeitos da informação contábil sobre o desempenho econômico variam conforme a sofisticação e extensão da cobertura dada pelos analistas financeiros. (YU, 2006). Pode-se considerar que a Contabilidade e as atividades dos analistas financeiros são complementares. Os analistas facilitam a interpretação e disseminação da informação contábil, enquanto um melhor nível de informação aumenta a acurácia das previsões dos analistas e, conseqüemente, afeta positivamente as suas recomendações. Por outro lado, as atividades dos analistas financeiros cobrem algumas limitações do sistema contábil, assim alguns pesquisadores (SUNDER, 1997; BEAVER, 1998; BUSHMAN; SMITH, 2001; HEALY; PALEPU, 2001; PALEPU et al, 2004) sugerem que esses sejam concorrentes da Contabilidade.

McKee $(2005$, p.31) afirma que os analistas financeiros, freqüentemente, estimam a volatilidade dos resultados através dos desvios dos números contábeis, já que uma maior variabilidade dos lucros prejudica a capacidade de previsão dos resultados futuros, afetando a percepção dos riscos sobre os investimentos.

Portanto, os analistas financeiros tornam-se agentes importantes no mercado de capitais, pois influenciam a tomada de decisão dos investidores. Tal capacidade de influenciar é devido ao treinamento específico, maior conhecimento sobre o setor a que a companhia pertence, observação regular das informações reportadas pela empresa e participação na conferência para divulgação dos relatórios contábeis. Assim, interagem com a administração da empresa e questionam sobre os diferentes aspectos dos números contábeis divulgados, exercendo o papel de monitores externos.

Mas, Healy e Papelu (2001) alertam que os relatórios dos analistas financeiros, bem como dos auditores, apesar de adicionar valor ao mercado de capitais, também são considerados como intermediários imperfeitos da informação, em parte por causa dos conflitos de interesses e por exercerem pressão excessiva sobre a administração.

Os analistas financeiros monitoram o desempenho das companhias para suportar as recomendações de investimentos feitas aos seus clientes. Em conseqüência, eles pressionam 
os administradores dessas empresas que observam suas previsões e recomendações. Por outro lado, existem pressões sobre os analistas para atingir os desejos dos investidores e, por isso, necessitam manter boas relações com a administração para acessar a informações privadas, além da necessidade de evitar a degradação das ações, nas quais os seus principais clientes têm significativos investimentos (YU, 2006, p.5-8). Por exemplo, algumas pesquisas evidenciam que os analistas financeiros são super-otimistas sobre novas emissões de títulos e valores mobiliários (RAJAN; SERVAES, 1997; TEOH; WONG, 1997).

Espera-se que ações dos auditores adicionem valor às informações reportadas, independentes dos interesses de seus clientes, entretanto, eles preferem minimizar suas obrigações legais a melhorar a evidenciação contábil para os investidores e demais usuários da Contabilidade. Para Healy e Palepu (2003, p.15-16), as empresas de auditoria reagem no ambiente empresarial de diversas maneiras, pois fazem lobby em favor da aprovação ou não de determinadas normas contábeis e de auditoria e desenvolvem procedimentos de trabalho que visam a minimizar os riscos de suas atividades. Esses fatos reduzem os custos da auditoria e fornecem melhores parâmetros nos casos de litígios. Porém, seu vínculo com a empresa auditada torna-se mais estreito e se distanciam do papel de julgador das informações contábeis divulgadas.

Os bancos de investimentos fornecem seus serviços de consultoria financeira para auxiliar as empresas na captação de recursos no mercado de capitais (PALEPU et al, 2004, p.I-15). Já as empresas de rating avaliam os riscos que podem impactar no retorno dos investimentos em títulos de dívidas através de informações disponíveis sobre a empresa emissora e elaboram uma classificação de riscos. Segundo Fortuna (2005, p.514), “o rating é importante porque é uma forma rápida de um investidor poder comparar as diferentes alternativas de investimento e decidir onde aplicar." Porém cabe destacar que o rating não é uma recomendação de investimento e sim uma opinião sobre a capacidade futura de cumprimento de suas obrigações no período esperado, portanto, está relacionada ao risco de crédito.

Para desempenhar seus papéis, esses intermediários da informação (bancos de investimentos e agências de rating) utilizam as informações contábeis divulgadas pelas empresas para atingir seus objetivos.

Diante desse cenário, considera-se que a relação entre os relatórios contábeis e os intermediários da informação é complexa, no qual Beaver (1998, p.10-11) reitera que a Contabilidade está em uma competição com outras fontes de informação, incluindo preços dos ativos. 
A Contabilidade disponibiliza publicamente um conjunto amplo de informações, que serve de subsídios para as atividades dos demais intermediários da informação. Mas como, a função dos intermediários é obter informação mais ampla e oportuna, tal fato pode torná-los concorrentes dos relatórios contábeis. Resumidamente, a informação contábil concorre com outras fontes de informações que podem ser geradas diretamente pela própria empresa ou pelos demais intermediários, ao mesmo tempo que as funções dos intermediários das informações são complementares.

\subsection{Qualidade das informações contábeis}

A Contabilidade tem como um de seus principais objetivos prestar informações úteis sobre as entidades aos seus diversos usuários, visto que parte é direcionada ao público externo. Entretanto, os usuários externos não escolhem diretamente os critérios de mensuração e/ou evidenciação contábil e nem mesmo o auditor responsável pelo exame das demonstrações contábeis, que sumarizam as conseqüências econômicas das atividades da empresa.

Com o crescimento da dimensão e da complexidade das atividades empresariais, as necessidades de informações por parte dos administradores e dos demais usuários da Contabilidade tornam-se cada vez mais distintas; no qual esses últimos precisam de uma crescente demanda de informações contábeis para que possam julgar o desempenho do administrador e da empresa, bem como para monitorar a elaboração e execução dos contratos. A qualidade da informação contábil está fortemente relacionada ao ambiente econômico, político e social em que a firma estiver inserida. Dechow e Schrand (2004, p.2) explicam que a "qualidade dos resultados é contextual, ela significa coisas diferentes para os diferentes usuários das demonstrações financeiras." ${ }^{16}$ Apesar de a afirmação utilizar o termo "qualidade dos resultados', a maior parte das considerações efetuadas nos trabalhos publicados (BALL, 1999; BARTH et al, 2001; DECHOW e DICHEV, 2002; DECHOW e SCHRAND, 2004; GIROUX, 2004; BURGSTAHLER et al, 2006) referem-se à 'qualidade da informação contábil', e que, nesta pesquisa, esses termos são semelhantes.

Normalmente, quando se discute a qualidade das informações contábeis (ou qualidade dos resultados) considera-se que existe uma baixa qualidade quando os relatórios contábeis são

\footnotetext{
${ }^{16}$ Tradução livre de: "Earnings quality is contextual; it means different things to different financial statements users."
} 
manipulados. Mas, observa-se que, em muitos casos, os problemas da qualidade da informação contábil estão relacionados ao excessivo montante de itens não recorrentes publicados ou falta de transparência, mesmo quando as escolhas contábeis foram realizadas em concordância com as normas contábeis vigentes. Assim, um conceito de qualidade de informação contábil torna-se complexo e depende do objetivo do seu usuário.

É importante reconhecer as limitações das demonstrações contábeis, pois apesar do seu objetivo principal estar diretamente relacionado com os interesses comuns dos diversos usuários potenciais, provavelmente, não seja possível atender, de forma idêntica, às necessidades de todos os grupos de usuários.

Para algumas empresas, mesmo com a ausência de manipulação de informações, os números contábeis podem ser considerados de baixa qualidade. Por exemplo, nos casos de empresas com alto crescimento, grande volume de recursos em ativos intangíveis ou com alta instabilidade do ambiente empresarial, as informações reportadas, segundo as normas contábeis, podem não ser úteis no auxílio da avaliação e/ou tomada de decisão.

A qualidade da informação contábil é um conjunto amplo de várias dimensões, nas quais se destacam (DECHOW; SCHRAND, 2004; GIROUX, 2004; BURGSTAHLER et al, 2006):
a) Persistência;
b) Conservadorismo e
c) Gerenciamento de resultados.

Além desses fatores, deve-se considerar que existem outras dimensões (atributos) da qualidade da informação contábil, como, por exemplo, transparência, nível de disclosure, relação dos números contábeis com o desempenho dos preços das ações ou do valor de mercado da firma.

Outro ponto relevante que, as empresas devem observar é a relação custo-beneficio no momento da elaboração e da evidenciação da informação contábil, o que, conseqüentemente, afeta a sua qualidade. Apesar da facilidade em se compreender que os benefícios decorrentes das informações devem exceder o custo de produzi-la, Hendriksen e Van Breda (1999, p.96) alertam que "apesar desta aparente simplicidade, é extremamente difícil fazer uma análise custo-benefício de informações contábeis; talvez até impossível”. A dificuldade dessa análise deve-se ao fato de que o custo da informação normalmente recai sobre o seu fornecedor, enquanto que seus benefícios gerados são auferidos tanto pelos produtores quanto pelos usuários. 
Portanto, o conceito do que seria 'qualidade da informação contábil' está relacionado ao consenso dos seus usuários, observando as características institucionais e organizacionais do mercado, levando-se em consideração os aspectos econômicos, sociais, culturais, geográficos e, inclusive, temporais.

\subsubsection{Persistência}

Numa perspectiva dos investidores, Dechow e Schrand (2004, p.5) definem que "os resultados são de alta qualidade quando os números dos resultados exatamente anualiza o valor intrínseco da firma." ${ }^{17}$ As autoras consideram que a anuidade dos fluxos futuros esperados de caixa é persistente e previsível, mas alertam que somente tais atributos não são indicadores de qualidade da informação contábil.

Com base nos dados da Enron Corporation no período de 1998 a 2001, elas mostram que, consistentemente a Enron tem lucro por ação (earnings per share - EPS) positivo e baixa surpresa positiva de EPS previsto até o segundo semestre de 2001, considerando assim que os resultados são previsíveis e persistentes. Mas, o mesmo não ocorre em setembro de 2001. (gráfico 1).

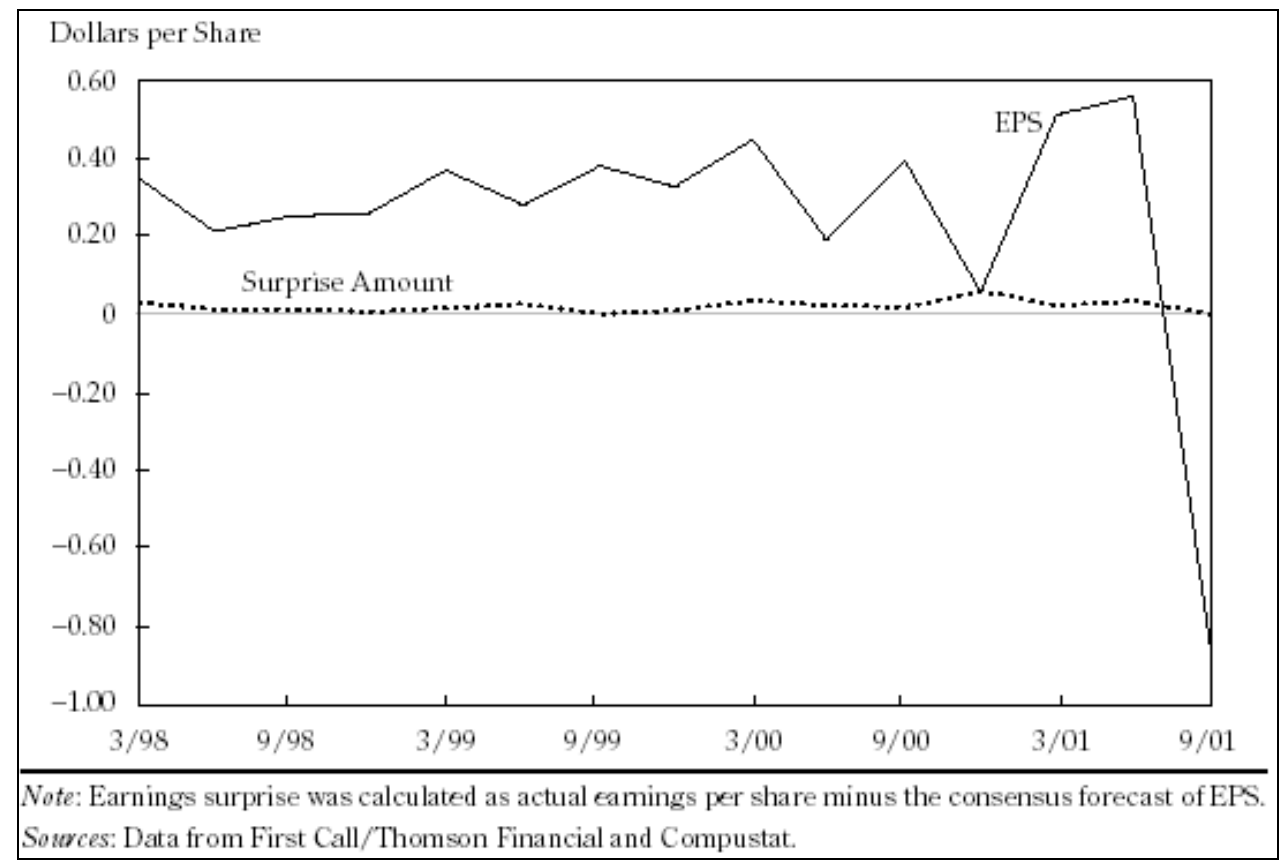

Gráfico 1 -Lucro por ação (EPS) e surpresa nos lucros da Enron (resultados trimestrais) Período: janeiro de 1998 a setembro de 2001

Fonte: Dechow e Schrand, 2004, p.6

\footnotetext{
${ }^{17}$ Tradução livre de: “[...] earnings to be of high quality when the earnings numbers accurately annuitizes the intrinsic value of the firm.",
} 
Observando o Gráfico 1, verifica-se que os números contábeis são persistentes até o segundo semestre de 2001, pois os fluxos de caixa são persistentes e previsíveis, devido à baixa surpresa dos resultados esperados, mas não podem ser considerados de alta qualidade. Então, Dechow e Schrand (2004, p.6) complementam afirmando que:

Maior persistência de resultados é uma definição significante para qualidade dos resultados, somente se os resultados verdadeiramente refletir o desempenho durante o período e se o desempenho do período corrente persiste nos períodos futuros. ${ }^{18}$

A qualidade dos resultados pode variar entre as empresas em função do regime de competência (accruals basis), mesmo sem intenção de manipulação. Para Dechow e Skinner (2000; p.238), o regime de competência tende a amortecer as flutuações nos fluxos de caixa da empresa, gerando um número que é mais útil ao investidor do que o fluxo de caixa operacional do período corrente.

Em certas situações, as atividades desenvolvidas pela empresa requerem um maior número de estimações e julgamentos e/ou aumento no volume de accruals nos números contábeis, como em empresas em crescimento ou no ramo de alta tecnologia. Provavelmente, esses accruals possuem maior erro de estimação (mesmo sem ações oportunísticas) e, conseqüentemente, reduzem a persistência dos resultados. Nesse caso, a baixa qualidade de resultados (definida pela persistência dos resultados) é relacionada à falha do sistema contábil em capturar certas transações ou eventos.

O grande interesse sobre a persistência dos resultados contábeis está no papel que exerce na previsão dos resultados futuros e, conseqüentemente, na avaliação do valor dos ativos. Quando ocorrem erros nas estimações dos accruals e resultados transitórios, como ganhos e perdas em instrumentos financeiros marcados a mercado, reduzem a persistência dos resultados e isso leva à perda da utilidade dos resultados no papel de avaliação e previsões.

\subsubsection{Conservadorismo}

Diversos estudos (BASU, 1997; AHMED et al, 2000; BALL et al, 2000; BALL; SHIVAKUMAR, 2005) conceituam o conservadorismo como o reconhecimento enviesado das más notícias, mais rapidamente do que as boas notícias.

Para Basu (1997, p.3), o conservadorismo é o resultado que reflete as más notícias (bad news), mais rapidamente do que as boas notícias (good news), levando às "diferenças

\footnotetext{
${ }^{18}$ Tradução livre de: "Greater earnings persistence is a meaningful definition for earnings quality only if earnings truly reflect performance during the period and if current-period performance persists in future periods."
} 
sistemáticas entre os períodos das más notícias e das boas notícias no timeless e persistência dos resultados".

Wagenhofer (2004, p.18) apresenta algumas formas comuns de práticas conservadoras, como, por exemplo:

a) A mensuração baseada no custo histórico não reconhece o incremento de valor, mas as normas requerem impairment no caso de declínio (conceito de custo ou mercado, dos dois o menor);

b) $\mathrm{O}$ não reconhecimento de muitos ativos intangíveis e, se reconhecidos, são pelos mesmos critérios de mensuração e evidenciação dos ativos tangíveis e não pelos seus potenciais benefícios futuros;

c) As perdas esperadas são reconhecidas quando elas se tornam conhecidas, enquanto os ganhos não são reconhecidos até serem realizados;

d) Deve-se atribuir maior peso às estimativas de perdas nos casos de dúvida.

O conservadorismo implica em decisões sobre o momento do reconhecimento oportuno dos ganhos e das perdas e, conseqüentemente, influenciando a escolha contábil. Porém, como outras características da informação contábil, o conservadorismo sofre influência do ambiente institucional e organizacional das empresas.

Watts (2003a; 2003b) traça um paralelo do conservadorismo com a persistência dos resultados, considerando que uma das conseqüências da presença do conservadorismo sobre os números contábeis é a persistência da subestimação dos valores do ativo líquido (ativo total menos passivo total), referentes aos efeitos acumulados no balanço patrimonial e nos resultados acumulados desde o inicio de suas operações.

Por outro lado, Holthausen e Watts (2001, p. 37) ponderam que o "conservadorismo pode ser devido às fontes de contração, litígio elou tributária, deste modo destacando-se aspectos de múltiplos objetivos das demonstrações financeiras" geral do conservadorismo é fornecer informações mais confiáveis aos investidores por meio de demonstrações que não sejam excessivamente otimistas."

Nesse sentido, o conservadorismo limita as ações dos gestores, disciplinando o "entusiasmo natural de alguns donos e administradores de negócios na apresentação das perspectivas da entidade" (IUDÍCIBUS, 2004, p.82) e contribuindo para o aumento da confiabilidade dos agentes externos sobre os números contábeis reportados.

\footnotetext{
${ }^{19}$ Tradução livre de: "Conservatism could be due to contracting, litigation and/or tax issues, thus highlighting the multi-purpose aspect of financial statements."
} 
Outro papel relevante do conservadorismo é sua influência no estabelecimento das relações contratuais entre a firma e seus credores, com intuito de assegurar garantias mínimas para o cumprimento das obrigações e na redução da probabilidade de que os recursos serão distribuídos inadequadamente para alguns agentes (WATTS, 2003a; 2003b; HOLTHAUSEN; WATTS, 2001). O conservadorismo pode minimizar o comportamento oportunístico dos administradores sobre os números contábeis, através da exigência assimétrica da verificabilidade, pois Watts (2003a, p.211) considera que as práticas contábeis são mais exigentes com o nível de verificação das boas notícias do que das más notícias.

Portanto, devido ao fato de que muitas das estimativas e julgamentos exercidos pela administração não possam ser verificadas, o conservadorismo torna-se um instrumento eficiente no estabelecimento dos contratos, pois restringe o comportamento oportunístico dos administradores, em benefício próprio ou dos outros interessados (HOLTHAUSEN; WATTS, 2001; WATTS, 2003a).

Entretanto, de forma teórica, a alta qualidade dos números contábeis deveria estar correlacionada positivamente à mensuração e evidenciação fidedigna e não-enviesada dos eventos e transações (neutralidade). Mas, a falta de verificabilidade, associada ao conservadorismo, conduz a Contabilidade reportar os números de forma assimétrica, incorporando mais rapidamente os maus resultados do que os bons resultados. $\mathrm{O}$ conservadorismo e a neutralidade devem ser compreendidos, adequadamente, em termos de seus benefícios e malefícios, buscando ampliar a probabilidade de se atingirem os objetivos dos relatórios contábeis.

Givoly e Hayn (2000, p.289) afirmam que os estudos devem analisar a relação entre o conservadorismo e as outras dimensões da informação contábil, como o gerenciamento de resultados, pois esse afeta os relatórios contábeis por causa dos custos políticos e incentivos contratuais.

Apesar de Ball et al (2000) apontarem que o conservadorismo está mais presente nos países commom-law do que nos países code-law. Lara et al (2005) evidenciam que os números contábeis apresentados pelas empresas do Reino Unido (common-law) e da Alemanha e França (code-law) têm uma redução significativa na diferença em relação ao reconhecimento assimétrico das boas e más notícias, quando são controlados os efeitos dos accruals discricionários ${ }^{20}$. A divergência entre esses trabalhos corrobora a afirmação de Pope e Walker

\footnotetext{
${ }^{20}$ Nesse trabalho (LARA et al, 2005, p. 704), o resultado não gerenciado é igual ao resultado antes dos itens extraordinários menos accruals discricionários (calculados pelo modelo Jones).
} 
(1999) de que se deve analisar com cuidado as evidências apresentadas nos estudos sobre a influência do sistema jurídico na mensuração e evidenciação contábil, pois os resultados encontrados dos modelos empíricos são sensíveis às variáveis de controle utilizadas, e podem alterar significativamente as conclusões sobre as características das informações contábeis.

Ball e Shivakumar (2005) apresentaram evidências de que o nível de conservadorismo é substancialmente menor nas companhias fechadas no Reino Unido, em relação às abertas. Analisando as demonstrações contábeis divulgadas no Brasil, Paulo et al (2006) apresentam evidências de que as companhias fechadas têm menor reconhecimento oportuno das perdas e, conseqüentemente, possuem menor nível de conservadorismo nos seus relatórios contábeis em relação ao das companhias abertas. Esses resultados sugerem que as características institucionais e organizacionais causam divergências nos níveis de conservadorismo entre empresas com estruturas societárias e econômicas diferentes, devendo ser observadas e analisadas pelos agentes econômicos em suas decisões.

\subsubsection{Gerenciamento de resultados}

Alguns autores (SCHROEDER et al, 2001; BURGSTAHER et al, 2006) consideram que gerenciamento de resultados é uma medida da qualidade contábil, pois é, particularmente, uma resposta aos incentivos de informações das firmas.

A utilização das informações contábeis como forma de distorcer propositalmente a realidade econômica da empresa é um dos temas mais abordados na literatura internacional (HEALY, 1985; DeANGELO, 1986; WATTS; ZIMMERMAN, 1986; JONES, 1991; DECHOW et al, 1995; KANG; SIVARAMAKRISHNAN, 1995; BURGSTAHLER; DICHEV, 1997; HEALY; WAHLEN, 1999; BARTOV et al, 2002; BARTOV; MOHANRAM, 2004). Apesar da grande importância do tema, no Brasil, poucos pesquisadores realizaram estudos empíricos (MARTINEZ, 2001; TUKAMOTO, 2004; FUJI, 2004; ZENDERSKY, 2005; CARDOSO, 2005; ALMEIDA, 2006).

$\mathrm{Na}$ hipótese de mercado eficiente, os investidores devem ser capazes de observar os resultados gerenciados, estando incluídos totalmente no preço das ações. Mas, considerando a Teoria dos Jogos, não existe equilíbrio no jogo sem gerenciamento de resultados. Esse fato reporta a situação do Dilema do Prisioneiro (Prisoner's Dilemma). Para o administrador será melhor se ele conseguir convencer os participantes do mercado de capitais que não está empregando práticas discricionárias. Todavia, desde que ele não consiga tal crédito, o 
mercado racionalmente espera um viés, e o administrador não tem outra melhor solução do que enviesar seu relatório até que as expectativas sobre o viés sejam realizadas na média. Assim, pode-se tornar difícil evitar o gerenciamento de resultados por parte dos administradores (WAGENHOFER, 2004, p. 20).

A Teoria da Agência fornece o Principio da Revelação (Revelation Principle), no qual se demonstra que qualquer resultado em equilíbrio de qualquer mecanismo, por mais complexo que seja, pode ser replicado por um resultado em equilíbrio verdadeiro de um mecanismo sobre o qual os agentes são exigidos a reportar suas informações privadas ao principal (Arya et al, 1998, p.7).

Para o estudo sobre manipulação das informações contábeis, esse princípio implica que qualquer ambiente manipulado pelos gestores da firma pode ser replicado por outro ambiente no qual o administrador reporte a verdadeira informação contábil. O principio demonstra que dado um contrato que induz à manipulação das informações contábeis, existe outro contrato que executa os mesmos resultados, mas induz à revelação da verdade pelo agente (WAGENHOFER, 2004, p. 20).

O Princípio da Revelação requer vários pressupostos restritivos, incluindo comunicação ilimitada, funções de compensação irrestrita e pré-compromissos ilimitados. Portanto, para o estudo sobre gerenciamento de resultados dentro do ambiente da Teoria da Agência, deve-se abandonar pelo menos um desses pressupostos.

Demski e Frimor (1999, p.187) afirmam que a manipulação contábil é um tipo de comunicação distorcida entre as partes e será somente um fenômeno consistente quando o princípio da revelação não for possível.

\subsection{Manipulação das informações contábeis}

A informação contábil busca apresentar, de forma fidedigna e imparcial, o verdadeiro desempenho econômico e financeiro da empresa. Considerando que os relatórios contábeis transmitem informações da empresa e da sua gestão aos usuários externos, as normas contábeis precisam permitir que os administradores usem de sua expertise para exercer julgamento sobre as demonstrações contábeis (HEALY; WAHLEN, 1999, p.366), com o intuito de reportar de forma mais adequada a realidade da empresa. Assim, a administração “desenvolve perspectivas sobre o quanto essa realidade é (ou como desviar de, no caso de 
manipulação de resultados) e como deve ser reportada"21 (GIROUX, 2004, p.2). Diante da possibilidade de desvio da realidade, uma das questões relevantes discutidas dentre os profissionais e órgãos reguladores da Contabilidade, é sobre os limites do julgamento dos gestores sobre os relatórios contábeis.

O amplo conjunto de critérios de mensuração e evidenciação contábil permitem que os administradores escolham uma das alternativas válidas a fim de divulgarem os relatórios da forma desejada. Healy e Wahlen (1999, p.368-370) consideram que o gerenciamento de resultados é uma conseqüência das ações discricionárias dos administradores para manipular as informações contábeis sobre o desempenho da empresa.

Baseado na abordagem positiva da Contabilidade, pode-se considerar que existem duas perspectivas sobre a manipulação das informações contábeis: oportunística e informacional (WATTS; ZIMMERMAN, 1986; SUBRAMANYAM, 1996; BENEISH, 2001). A primeira perspectiva inclui aquelas situações em que os administradores procuram enganar os investidores, enquanto a segunda, refere-se àquelas em que a discrição gerencial é uma forma dos administradores revelarem aos investidores suas expectativas privadas sobre os fluxos futuros de caixa da firma.

Diante da perspectiva oportunística, espera-se que o administrador atue com o intuito de maximizar a sua utilidade sobre a firma, às vezes, em detrimento dos interesses dos acionistas e credores. Esse oportunismo pode ocorrer, entre outras relações, como, por exemplo, acionistas principais e minoritários, administradores e credores, administradores e governo, administração e empregados, entre outros.

Entretanto, o comportamento oportunístico pode ser antecipado no momento da elaboração dos contratos e, conseqüentemente, são estabelecidos, ex ante, mecanismos próprios de defesa contra a expropriação dos gestores, como, por exemplo, redução da remuneração formal dos administradores firmados com os investidores ou na elevação dos custos de financiamento na concessão de créditos financeiros junto às instituições financeiras.

Por outro lado, devido às forças do mercado de trabalho, o administrador pode aceitar uma menor remuneração, mas visualiza as possibilidades de aumento de sua riqueza através do comportamento oportunístico.

Observando o gerenciamento de resultados sob a perspectiva oportunística, Wagenhofer (2004, p. 20) considera que tal prática impõe uma sobrecarga negativa sobre a economia. A

\footnotetext{
${ }^{21}$ Tradução livre de: "[...], develops a perspective on what this economic reality is (or how to deviate from it in the case of earnings manipulation) and how it should be reported."
} 
manipulação das informações contábeis pode trazer alguns prejuízos aos seus diversos usuários, como, por exemplo:

a) Investidores: não possuem informações confiáveis para auxiliá-los na decisão de alocação de seus recursos e podem ter uma parcela de sua riqueza expropriada pelos gestores ou pelos acionistas principais;

b) Analistas financeiros: estimam resultados erroneamente, e portanto, apresentam recomendações de investimentos aos seus clientes de forma ineficiente;

c) Instituições de crédito e de financiamento: não têm a verdadeira percepção sobre riscos inseridos em suas negociações;

d) Entidades reguladoras do mercado e da profissão contábil: vêem tal prática prejudicar o bom funcionamento do mercado ou do setor;

e) Entidades fazendárias: podem ser prejudicadas por esse tipo de comportamento empresarial que, por exemplo, seria utilizado como uma forma de sonegação de tributos;

f) Entidades sindicais: não possuem informações confiáveis sobre a situação econômica e financeira da empresa para auxiliá-las nas negociações trabalhistas e

g) Entidades não-governamentais: lutam contra a concentração de riqueza e abuso do poder econômico, principalmente, aqueles que trazem prejuízos sociais e ambientais.

Diante dos prejuízos aos diversos participantes da economia, torna-se também relevante que o conjunto de normas contábeis restrinja a possibilidade de emprego da manipulação das informações. A discussão sobre manipulação das informações contábeis, na perspectiva oportunística, está baseada na possibilidade de que o mercado não é eficiente, sendo originada principalmente do desejo de influenciar a possibilidades de transferências de riquezas entre os vários agentes econômicos (DECHOW; SKINNER, 2000; STOLOWY; BRETON, 2004).

Pela perspectiva da contratação eficiente seria desejável que, em certos casos, os administradores gerenciem os resultados da empresa, quando as informações reportadas estiverem incompletas ou inadequadas devido à observância rígida de normas e contratos (SCOTT, 2003, p.385). Pelo menos em termos teóricos, pode-se considerar, por essa perspectiva, que a manipulação das informações contábeis tem um papel econômico importante, inclusive, podendo ser uma resposta à má regulamentação contábil para determinado eventos ou transações econômicas.

Portanto, o pesquisador deve ser cauteloso quando analisar suas evidências sobre a perspectiva oportunística, pois o gerenciamento pode ser uma forma de comunicação de 
informações do gestor (insider information) para o mercado, com o objetivo de melhor previsão sobre o desempenho futuro da firma. Mas, diante da diversidade de incentivos e formas de gerenciamento de resultados, adicionados à dificuldade em identificar e interpretar os efeitos discricionários, torna-se complexa a evidenciação empírica de quando tal prática se enquadra sob uma perspectiva oportunística ou de eficiência.

Então, poderiam ser levadas questões, como, por exemplo: O mercado consegue identificar as boas ou más práticas de gerenciamento de resultados? Como o mercado reage? Essas, talvez, são duas perguntas relevantes na perspectiva de eficiência sobre manipulação das informações contábeis, mas que não se enquadram no escopo deste trabalho.

Assim, apresenta-se a seguinte dicotomia: a manipulação das informações contábeis é um conjunto de esforços para melhorar a qualidade das informações reportadas ao público externo ou uma prática intencional com intuito de distorcer as informações contábeis para atender aos propósitos específicos da empresa e ou de seus principais acionistas e altos executivos (top manager)? A solução para tal questionamento torna-se complexa devido ao grande número de fatores que envolvem a discussão sobre o tema.

\subsubsection{Conceitos}

Dada uma variedade de ambientes empresariais, provavelmente qualquer explicação não será totalmente completa para conceituar a manipulação das informações contábeis. Entretanto, para auxiliar no desenvolvimento deste trabalho e na compreensão do tema abordado, nessa secção serão discorridos mais detalhadamente os termos utilizados nessa linha de pesquisa.

A literatura acadêmica e profissional tem apresentado o tema de forma diversificada e os termos mais comumente encontrados são 'gerenciamento de resultados' (earnings management) e 'contabilidade criativa' (criative accounting). $\mathrm{O}$ primeiro refere-se a uma determinada forma de manipulação das informações contábeis, enquanto o segundo termo não retrata o verdadeiro propósito desta pesquisa, pois a utilização do termo 'criativo' pode corresponder às práticas inovadoras que buscam aperfeiçoar as informações contábeis (CARDOSO, 2005, p.21).

Além desses termos, a prática discricionária possui outras denominações, como, por exemplo, suavização de resultados (income smoothing), big bath accounting e maquiagem de demonstrações contábeis (window dressing). A falta de consenso sobre a conceituação dos 
termos utilizados ${ }^{22}$ sobre esse tema, pode conduzir a interpretações diferentes para os leitores leigos no assunto.

Para Healy e Wahlen (1999, p. 368):

Gerenciamento de resultados ocorre quando os administradores usam julgamento sob a informação financeira e sobre as atividades operacionais para alterar informações financeiras, ou iludir alguns investidores sobre o desempenho econômico da companhia, ou para influenciar resultados contratuais que dependam dos números contábeis informados. ${ }^{23}$

McKee (2005, p.1) define o gerenciamento de resultados como uma tomada de decisão razoável e legal sobre a informação cuja intenção é alcançar resultados financeiros estáveis e previsíveis. Scott (2003, p.369) afirma que o "gerenciamento de resultados é a escolha por um administrador da política contábil de forma que atinja alguns objetivos específicos"24.

Schipper (1989, p.92) amplia o escopo de estudo sobre gerenciamento de resultados, denominando como 'gerenciamento de disclosure' (disclosure management), que se refere à "uma intervenção intencional no processo de informação financeira externa, com a intenção de obter ganhos particulares." ${ }^{25}$ Giroux (2004, p.2), também, amplia o conceito, considerando como o uso das atividades operacionais e dos métodos contábeis discricionários para ajustar os números para um resultado desejado.

A manipulação da informação contábil pode ocorrer não somente pela modificação artificial dos números contábeis, mas também pela apresentação de certos aspectos econômicos e financeiros através do off-balance sheet.

Cabe, nesse ponto do presente trabalho, estabelecer uma distinção entre a 'manipulação da informação contábil' e 'contabilidade fraudulenta'. A primeira ocorre quando os administradores utilizam do seu julgamento sobre as escolhas contábeis dentro dos limites legais, ou seja, a escolha das práticas adotadas está de acordo com as normas contábeis vigentes. Por outro lado, a contabilidade fraudulenta refere-se a ações que estão fora das normas contábeis aceitas, constituindo-se em fraude contábil, como, por exemplo, reconhecer vendas fictícias ou reconhecimento de parte das receitas totais efetivamente ocorridas.

\footnotetext{
${ }^{22}$ McKee (2005, p.3) relaciona 15 termos que têm sido utilizados para descrever a prática de manipulação das informações contábeis. Além dos elencados pelo referido autor, existem outros descritos na literatura acadêmica e profissional.

${ }^{23}$ Tradução livre de: "Earnings management occurs when managers use judgment in financial reporting and in structuring transactions to alter financial reports to either mislead some stakeholders about the underlying economics performance of the company or to influence contractual outcomes that depend on reported accounting numbers."

${ }^{24}$ Tradução livre de: "Earnings management is the choice by a manager of accounting policies so as to achieve some specific objective."

${ }^{25}$ Tradução livre de: "a purposeful intervention in the external financial reporting process, with the intent of obtaining some private gain."
} 
Um conceito mais restritivo seria somente considerar que houve manipulação das informações contábeis, quando o sistema jurídico ou os organismos fiscalizadores, como a Comissão de Valores Mobiliários (CVM) ou Banco Central do Brasil (BACEN), resolver que uma determinada empresa tem praticado tal ato. Nesse conceito, normalmente, se enquadra como contabilidade fraudulenta.

Observam-se, então, alguns pontos em comum nos conceitos sobre manipulação da informação contábil:

a) possibilidade de incluir práticas reais de manipulação como atividades operacionais, decisões de financiamento e investimentos;

b) ações dos administradores estão dentro do ambiente regulatório dos relatórios contábeis, em relação a estruturação das transações;

c) permite incluir as possibilidades de alterar indicadores de desempenho, quando for de interesse de algum agente para que isso ocorra.

Critérios alternativos de reconhecimento, mensuração e evidenciação estabelecidos dentro do sistema contábil criam oportunidades para que os administradores escolham uma das alternativas válidas, podendo retratar as informações da forma desejada, assim conseqüentemente, distorcendo a análise do desempenho empresarial. Essa prática intencional de distorção das informações contábeis é denominada, neste trabalho, como 'manipulação das informações contábeis'.

Neste trabalho, a manipulação das informações contábeis é conceituada como a utilização de ações discricionárias por parte dos administradores para influenciar a interpretação da realidade econômica e financeira da empresa, através das atividades operacionais ou das escolhas contábeis.

Segundo Stolowy e Breton (2004, p.6), essa prática é motivada pelas possibilidades de transferência de riqueza entre a companhia e a sociedade (custos políticos), fontes de recursos (custo de capital) ou para os próprios administradores (planos de compensação); sendo que as duas primeiras situações tentam beneficiar a empresa e seus proprietários, diferentemente do que ocorre na última situação.

Entretanto, Deckow e Skinner (2000, p.238) afirmam que apesar desses conceitos serem amplamente aceitos, são de difícil operacionalização metodológica em pesquisas, especialmente, no que se refere à intenção dos administradores, pois essa não é observável.

Apesar de existir diversas características, certamente, que todos eles modificam os números contábeis conforme os propósitos de quem pratica a discricionariedade. A administração, sob 
a perspectiva da eficiência, acredita que as práticas de manipulação contábil influenciam a percepção dos investidores sobre a companhia, que os demais custos (ou riscos) associados são menores do que os benefícios proporcionados. $\mathrm{Na}$ perspectiva oportunística, o gerenciamento de resultado só existe pela incapacidade de detecção pelas outras partes da relação contratual (FIELDS et al, 2001, p.260).

Independentemente do critério contábil utilizado, quando uma empresa divulga o conjunto de relatórios contábeis de forma transparente, apresentando claramente em notas explicativas os critérios utilizados para o diferimento ou antecipação de uma receita ou despesa, e sua respectiva reversão, pode ocorrer gerenciamento de resultados? Tal questionamento foi abordado por Deckow e Skinner (2000), em que demonstram que, na visão dos executivos, tal procedimento, nessa circunstância, não se constitui em evidência de manipulação das informações contábeis.

\subsubsection{Incentivos para a manipulação das informações contábeis}

Uma ampla literatura apresenta evidências sobre o comportamento oportunista dos administradores em diversas situações. Os incentivos para a manipulação das informações contábeis são originados da regulamentação, contratos de dívidas, remuneração dos altos executivos e, emissão e negociação de títulos mobiliários. Dentre os incentivos mais analisados pela literatura estão (HEALY, 1985; DECHOW et al, 1995; BURGSTAHLER; DICHEV, 1997; HEALY; WAHLEN, 1999; SHACKELFORD; SHEVLIN, 2001; MARTINEZ, 2001; BARTOV et al, 2002; BARTOV; MOHANRAM, 2004; FUJI, 2004; TUKAMOTO, 2004; ZENDERSKY, 2005; CARDOSO, 2005; BURGSTAHLER et al, 2006):

a) Evitar divulgação de perdas contábeis

Um dos motivos mais analisados pela literatura é a prática discricionária para evitar que a empresa divulgue resultados negativos. Se os administradores sabem que os preços das ações respondem fortemente a notícias de resultados adversos, espera-se que eles tentem evitar a divulgação de perdas, principalmente, se os próprios tiverem um grande volume de recursos aportados na companhia. 
b) Minimizar volatilidade dos resultados ao longo do tempo

Como comentado anteriormente, a suavização dos resultados (smothing income) tem como intuito refletir um crescimento constante dos lucros, através da redução da variabilidade dos resultados ao longo do tempo, tornando-se um dos principais incentivos explorados pela pesquisas na literatura atual.

A estratégia de utilização dos accruals para reduzir os resultados no período corrente é conhecida como taking a bath. A racionalidade para esse incentivo é que, quando se atinge determinado nível de desempenho, ou mesmo de remuneração, é melhor transferir parte dos lucros correntes para um momento futuro e, conseqüentemente, 'estocar' parte dos resultados para períodos de maiores dificuldades.

Myers et al (2006) analisaram o comportamento dos resultados de companhias norteamericanas, no período de 1963 a 2004, e evidenciaram que existem 746 firmas que suavizam seus resultados contábeis, apresentando um crescimento anormal (acima de companhias em circunstâncias econômicas idênticas) ao longo de período superior a 20 trimestres (cinco anos). Assim, essa pesquisa mostra que os administradores utilizam as escolhas contábeis para sustentar o crescimento dos resultados.

c) Remuneração baseada em desempenho, incluindo stock options

$\mathrm{Na}$ tentativa de alinhamento dos interesses dos administradores com o dos acionistas, nas últimas décadas, as corporações têm implementado a utilização das stock options como forma de remuneração dos seus principais executivos baseando-se no desempenho empresarial (BARTOV; MOHANRAM, 2004, p.891). Dechow e Skinner (2000, p.236-237) argumentam que elevação do mercado de capitais durante a década de 1990 e o crescente uso das stock options como forma de compensação dos administradores têm incentivado a manipulação dos resultados com o intuito de manter as excelentes valorizações das ações. Bartov e Mohanram (2004) evidenciaram retornos anormais positivos nos períodos que antecedem o exercício da stock options pelos principais executivos da empresa.

d) Ajustar resultados às previsões dos analistas financeiros

Outro incentivo relevante para a manipulação dos números contábeis está associado ao ajustamento dos resultados à previsão dos analistas financeiros. Alguns estudos (BARTOV et al, 2002; STOWOLY; BRETON, 2004) apontam que as companhias que atingiram ou superaram as expectativas dos analistas, obtiveram um 'prêmio' no momento da negociação 
de seus títulos no mercado, devido à percepção de menor risco associado aos resultados futuros.

e) Lançamento de títulos no mercado de capitais

Quando da oferta pública de ações, a administração busca captar o maior volume de recursos, enquanto os investidores procuram pagar o menor preço pela ação. Esse fato cria a possibilidade dos administradores agirem discricionariamente, motivados a aumentar o preço das ações, existindo evidências empíricas que comprovam tal hipótese no contexto internacional (TEOH et al, 1998; ROOSENBOOM et al, 2003; DARROUGH; RANGAN, 2005).

Entretanto, no mercado de capitais brasileiro a oferta de outros títulos tem uma participação relevante no volume de negócios registrado na CVM. A Tabela 01 apresenta o montante de ofertas primárias registradas na CVM entre janeiro de 1997 a julho de 2007. Verifica-se que a oferta de debêntures teve um volume de recursos financeiros bem superior em todo o período. Além disso observa-se que, a partir de 2004, nas negociações primárias com quotas dos Fundos de Investimento (de Direitos Creditórios e em Participações) se transformaram uma das principais opções de investimentos no mercado brasileiro, pois eles "foram criados com o objetivo de dar liquidez ao mercado de crédito, reduzindo o risco e ampliando a oferta de recursos" (FORTUNA, 2005, p.492), tornando-se uma opção de financiamento alternativo pelas empresas.

Tabela 1 - Ofertas primárias registradas na CVM de janeiro de 1997 a julho de 2007.

\begin{tabular}{|c|c|c|c|c|c|c|}
\hline & & & & & \multicolumn{2}{|c|}{ Em milhões de reais } \\
\hline Título & 1997 & 1998 & 1999 & 2000 & 2001 & \\
\hline Ações & 3.965 & 4.112 & 2.749 & 1.410 & 1.353 & \\
\hline Debêntures & 7.518 & 9.657 & 6.676 & 8.748 & 15.162 & \\
\hline Notas Promissórias & & 12.903 & 8.044 & 7.591 & 5.266 & \\
\hline Quotas de FIDC / FIC-FIDC / FIDC-NP & & & & & & \\
\hline Quotas de FIP / FIC-FIP & & & & & & \\
\hline Outros & 317 & 1.177 & 442 & 1.290 & 1.352 & \\
\hline Total & 11.800 & $\mathbf{2 7 . 8 5 0}$ & $\mathbf{1 7 . 9 1 2}$ & 19.039 & 23.134 & \\
\hline Título & 2002 & 2003 & 2004 & 2005 & 2006 & $\begin{array}{c}\text { até } \\
07 / 2007\end{array}$ \\
\hline Ações & 1.050 & 230 & 4.470 & 4.365 & 14.223 & 23.626 \\
\hline Debêntures & 14.636 & 5.282 & 9.614 & 41.539 & 69.464 & 29.009 \\
\hline Notas Promissórias & 3.876 & 2.128 & 2.241 & 2.632 & 5.279 & 8.083 \\
\hline Quotas de FIDC / FIC-FIDC / FIDC-NP & & & 5.135 & 8.579 & 12.777 & 5.842 \\
\hline Quotas de FIP / FIC-FIP & & & & & 4.776 & 9.222 \\
\hline Outros & .762 & 2.793 & 2.984 & 4.492 & 3.659 & 2.928 \\
\hline Total & 21.324 & 10.433 & 24.444 & 61.606 & $\mathbf{1 1 0 . 1 7 7}$ & 78.710 \\
\hline
\end{tabular}

\footnotetext{
Fonte: Brasil, 2007.
} 
Quando da emissão, esses títulos públicos são avaliados por empresas de rating que utilizam as diversas informações disponíveis sobre a empresa, entre elas as informações contábeis, com o objetivo de atribuir um grau de risco dos papéis a serem negociados. Portanto, os gestores têm incentivos para agir oportunisticamente com o objetivo de melhorar o rating atribuído aos papéis negociados publicamente pela empresa, o que, conseqüentemente, leva à redução do custo de capital.

f) Cumprir exigências contratuais de dívidas (debt covenants) e renovação de contratos de financiamentos e/ou empréstimos

A literatura contábil apresenta a possibilidade de os administradores utilizarem as escolhas contábeis para reduzir a probabilidade das empresas violarem as cláusulas contratuais dos contratos de dívidas (debt covenants). A utilização de praticas discricionárias para esse incentivo está ligada aos custos (custos do default técnico) e conseqüências subseqüentes ao momento da violação.

O não cumprimento das exigências dos contratos de empréstimos também interfere no momento da renovação de contratos de financiamentos e empréstimos. No caso de renovação de dívida devem ser levados em consideração os riscos implícitos no contrato, o histórico dos pagamentos das obrigações anteriores, a liquidez e rentabilidade da empresa, bem como o cumprimento das demais exigências contratuais.

g) Fiscalização ou monitoramento setorial das agências regulatórias

O ambiente regulatório também apresenta incentivos para a manipulação das informações contábeis. Em alguns setores empresarias, torna-se mais forte a presença de fiscalização ou monitoramento das atividades empresarias, como, por exemplo, as instituições financeiras, as empresas de seguros, geração e fornecimento de fontes de energia, etc. As práticas discricionárias estão delineadas para atingir certas metas, como a manutenção de certos níveis financeiros e econômicos que servem para mensurar os riscos associados à execução das atividades empresariais. Cardoso (2005) evidencia que as companhias do mercado de saúde suplementar brasileiro utilizam de escolhas contábeis para atender as exigências mínimas requeridas pela Agência Nacional de Saúde Suplementar (ANS) ${ }^{26}$, portanto, respondendo ao processo de regulação desse mercado.

\footnotetext{
${ }^{26}$ Agência reguladora responsável pela normatização, controle e fiscalização das atividades desempenhadas pela empresas do ramo de saúde suplementar no Brasil.
} 
h) Redução da carga tributária

A tributação sobre a atividade empresarial em muitos países, normalmente, é baseada no lucro líquido do período de apuração, ajustado pelas adições, exclusões e compensações prescritas ou autorizadas pelas normas pertinentes. Portanto, os números contábeis, em particular o resultado, têm um papel relevante no planejamento tributário das empresas. Shackelford e Shevlin (2001, p.326) apontam que as estratégias de planejamento tributário (redução da carga tributária), normalmente, conduzem à redução dos resultados contábeis reportados.

Burgstahler et al (2006, p.985) apresentam evidências da existência de que um forte alinhamento entre o resultado contábil e a tributação está diretamente associado com maior nível de gerenciamento de resultados por parte das empresas. Phillips et al (2003) e Krull (2004) argumentam que existe uma maior flexibilidade no sistema contábil do que no tributário, permitindo um maior volume de accruals discricionários em cada período, afetando os resultados contábeis reportados, mas que não provoca um aumento da carga tributária e, conseqüentemente, não tem influência no caixa da empresa.

Entretanto, no Brasil, grande parte dos tributos arrecadados é calculada sobre o valor das receitas totais e não pelo lucro líquido do período, sendo que os principais tributos calculados sobre faturamento são: Imposto sobre Produtos Industrializados - IPI, Contribuição para a Seguridade Social - Cofins, Contribuição para o Programa de Integração Social/Programa de Formação do Patrimômio do Servidor Público - PIS/PASEP e Contribuição de Intervenção no Domínio Econômico - CIDE Combustíveis (esfera federal), Imposto sobre Operações relativas à Circulação de Mercadorias e sobre Prestações de Serviços de Transporte Interestadual, Intermunicipal e de Comunicação - ICMS (esfera estadual) e Imposto sobre Serviços de Qualquer Natureza - ISS (esfera municipal).

Conforme a Tabela 2, o total da arrecadação do IRPJ - Lucro Real e a CSLL (calculados sobre o resultado liquido do exercício) representa $15,8 \%$ da arrecadação total das receitas administradas pela Secretaria da Receita Federal - SRF no ano de 2004 e 17,9\% no ano de 2005, enquanto IPI, Cofins, PIS/PASEP, CIDE e IRPJ - Lucro Presumido (também calculado sobre as receitas) perfazem um percentual de $45,3 \%$ para o ano de 2004 e $43,8 \%$ para o ano de 2005. Isso demonstra a relevância dos tributos baseados sobre a receita das empresas. 
Tabela 2 - Arrecadação das receitas administradas pela Secretaria da Receita Federal - anos de 2004 e 2005 (em milhões de reais).

\begin{tabular}{|l|r|r|r|r|}
\hline \multirow{2}{*}{\multicolumn{1}{|c|}{ Receitas }} & \multicolumn{2}{c|}{$\mathbf{2 0 0 4}$} & \multicolumn{2}{c|}{$\mathbf{2 0 0 5}$} \\
\cline { 2 - 5 } & \multicolumn{1}{c|}{ Valor } & \multicolumn{1}{c|}{$\mathbf{\%}$} & \multicolumn{1}{c|}{ Valor } & \multicolumn{1}{c|}{$\%$} \\
\hline Imposto sobre Importação - II & 9.202 & $3,1 \%$ & 9.086 & $2,6 \%$ \\
\hline Imposto sobre Produtos Industrializados - IPI & 22.910 & $7,6 \%$ & 26.373 & $7,6 \%$ \\
\hline Imposto de Renda - Pessoas Físicas & 6.136 & $2,0 \%$ & 7.341 & $2,1 \%$ \\
\hline Imposto de Renda - Pessoas Jurídicas & 39.039 & $13,0 \%$ & 51.130 & $14,7 \%$ \\
\hline \multicolumn{1}{|c|}{ Lucro Real } & 26.774 & $9,0 \%$ & 35.837 & $10,3 \%$ \\
\hline Lucro Presumido & 6.572 & $2,2 \%$ & 7.990 & $2,3 \%$ \\
\hline Outros & 5.533 & $1,8 \%$ & 7.303 & $2,1 \%$ \\
\hline Imposto de Renda - Retido na Fonte & 57.815 & $19,3 \%$ & 66.147 & $19,1 \%$ \\
\hline Impostos sobre Operações Financeiras - IOF & 5.254 & $1,8 \%$ & 6.102 & $1,8 \%$ \\
\hline Imposto Territorial Rural - ITR & 292 & $0,1 \%$ & 324 & $0,1 \%$ \\
\hline Contr. sobre a Movimentação Financeira - CPMF & 26.433 & $8,8 \%$ & 29.230 & $8,4 \%$ \\
\hline Contribuição para a Seguridade Social - Cofins & 79.236 & $26,4 \%$ & 87.902 & $25,3 \%$ \\
\hline Contribuição para a PIS/PASEP & 19.997 & $6,6 \%$ & 22.046 & $6,4 \%$ \\
\hline Contribuição Social sobre o Lucro Líquido - CSLL & 20.414 & $6,8 \%$ & 26.323 & $7,6 \%$ \\
\hline CIDE - Combustíveis & 7.669 & $2,5 \%$ & 7.680 & $2,2 \%$ \\
\hline Pagamento Unificado & 2.745 & $0,9 \%$ & 3.136 & $0,9 \%$ \\
\hline Contribuição para o Fundaf & 301 & $0,1 \%$ & 306 & $0,1 \%$ \\
\hline Outras Receitas Administrativas & 3.087 & $1,0 \%$ & 3.831 & $1,1 \%$ \\
\hline Total & $\mathbf{3 0 0 . 5 3 0}$ & $\mathbf{1 0 0 \%}$ & $\mathbf{3 4 6 . 9 5 7}$ & $\mathbf{1 0 0 \%}$ \\
\hline
\end{tabular}

Fonte: Brasil, 2006a.

Conforme os dados coletados junto à Secretaria da Receita Federal (BRASIL, 2006b), o ICMS, que também tem como base de cálculo o faturamento das empresas, teve uma arrecadação de R\$ 138,3 bilhões em 2004 e R\$ 154,8 bilhões em 2005, o que reflete uma carga tributária de $8,0 \%$ sobre o Produto Interno Bruto (PIB), sendo superior a do Imposto de Renda $(6,8 \%)$.

Portanto, pode-se esperar que, no contexto brasileiro, a manipulação das receitas exerça um forte impacto nos números contábeis e no caixa, devido à grande carga tributária sobre o faturamento, diferentemente de outros países, como os Estados Unidos da América, onde o imposto sobre o valor agregado nas vendas não é considerado como parte da receita total e a empresa simplesmente cobra do consumidor e repassa ao governo. Logo, essa característica do sistema tributário brasileiro pode inibir a manipulação das receitas (para cima) das empresas, pois tem reflexos financeiros e conduz à redução do valor da firma no longo prazo. Apesar da relevância, não existe nenhum estudo sobre as práticas de gerenciamento de resultados e os tributos calculados sobre faturamento no contexto brasileiro, o que poderia conduzir a novas hipóteses sobre a relação da Contabilidade e o sistema tributário e, conseqüentemente, contribuir para o entendimento da influência dos números contábeis na gestão empresarial.

Um exemplo seria o caso da companhia norte-americana Xerox, maior fabricante de copiadoras do mundo, que entre 1997 e 2000, registrou US\$ 2 bilhões de receitas a maior 
referentes a atividades de sua unidade no Brasil. Essa prática de manipulação, se praticada por empresas brasileiras, acarretaria uma carga tributária e, em conseqüência, um desembolso financeiro futuro para quitar os tributos devidos. Assim, a forma de tributação sobre o faturamento no Brasil inibe algumas práticas de manipulação de resultados, em especial, as que aumentam resultados através de receitas fictícias.

Outro ponto a ser observado é que os incentivos tributários para o gerenciamento de resultados podem ser atingidos pelas escolhas contábeis ou por meio da manipulação das atividades operacionais da empresa. Nesse caso, deve-se considerar que existem outras forças atuantes que podem inibir ou não a manipulação contábil, como, por exemplo, fiscalização, concorrência e política de vendas.

\section{i) Outros incentivos econômicos e/ou financeiros}

Existem muitos outros incentivos para a manipulação das informações contábeis, que ainda foram pouco explorados pela literatura. Por exemplo, as escolhas contábeis podem ser utilizadas para reduzir o resultado no período próximo à mudança de gestão da companhia. Os novos administradores se beneficiam, pois no período em que assumem o cargo ou o período imediatamente posterior a esse, um mau resultado pode ser atribuído à gestão anterior, postergando boas notícias e, conseqüentemente, transferindo resultados positivos para futuros períodos. Nos períodos posteriores, quando a capacidade da gestão corrente será avaliada, os resultados tornam-se mais satisfatórios do que no passado, logicamente, influenciando positivamente a reputação do gestor e sua remuneração. Essa situação pode ocorrer, também, na troca do controle acionário de uma companhia que necessita captar recursos no mercado de capitais ou de crédito.

Adicionalmente, existe a possibilidade de escolha de certos critérios de alocação de gastos entre os centros de custos de uma mesma entidade econômica e transferências de receitas entre empresas interligadas, de forma que os resultados alcancem certas metas estabelecidas. Nesse caso, pode existir o gerenciamento de resultados através das operações intercompanhias de forma que beneficie uma das partes interessadas, provavelmente, os gestores e/ou acionistas controladores.

Por exemplo, é comum que um conglomerado financeiro instale no mesmo espaço físico uma banco comercial, banco de investimentos, seguradora, etc. Além do espaço físico, essas diversas empresas (do mesmo grupo econômico) compartilham de toda a infra-estrutura operacional e administrativa, como, funcionários e equipamentos. Porém, esses gastos são realizados financeiramente por uma das empresas. A questão a ser analisada é como a 
empresa que honrou o compromisso financeiro recupera (se for o caso) a parcela dos gastos que deve ser atribuída economicamente às demais empresas.

Cabe ressaltar que, a prática de manipulação de alocação de despesas e transferências de receitas também pode afetar a avaliação de desempenho interna das diversas unidades econômicas da empresa, o que torna de interesse direto da contabilidade gerencial. A manipulação de informação contábeis no âmbito gerencial é um campo ainda inexplorado nas pesquisas contábeis.

j) Incentivos além dos aspectos econômicos e financeiros

Além dos incentivos econômicos e financeiros, pode-se considerar que existam motivações psico-sociais para que os administradores tenham comportamento oportunístico. Apesar da relação intrínseca entre a manipulação das informações e as características pessoais e ambientais, poucas pesquisas foram realizadas sob essa ótica comportamental.

Dentre essas motivações que não são de caráter financeiro e/ou econômico, destacam-se: pressão empresarial, reputação, possibilidade de detecção e moral. Obviamente, existem outros fatores relacionados à cultura organizacional que influenciam potencialmente a prática da manipulação das informações contábeis.

Segundo Wolk et al (1992, p. 73), os administradores têm incentivos para apresentar informações contábeis de boa qualidade, pois sua reputação será ampliada pela melhoria da qualidade dos relatórios contábeis reportados. Duncan e Knoblett (2000, p.26-33) corroboram afirmando que os incentivos para gerenciar os números contábeis estão relacionados com a maximização das compensações financeiras, manutenção do status quo e alcance de promoção pessoal. Cabe ressaltar que, uma melhor reputação dos gestores também influencia na redução do custo de capital da empresa.

Apesar de, os adminstradores serem julgados e recompensados pela qualidade das informações contábeis divulgadas, eles sofrem pressões ambientais na empresa, como, por exemplo, atingir lucros estabelecidos, ampliar a participação do mercado consumidor, superar os concorrentes diretos, etc.

Duncan e Knoblett (2000, p.34-35) apontam que o nível moral dos contadores e dos auditores é um fator preponderante na execução de suas atividades profissionais e inibe a prática oportunística. Por outro lado, as pessoas (mesmo com um baixo nível moral) evitam essa prática quando existe forte possibilidade de seu comportamento oportunístico ser detectado.

Bazermam (2004, p.2) alerta que fraudes contábeis nem sempre são resultantes de conluio deliberado entre o auditor e o cliente e que as falhas de auditoria podem ter explicações nos 
vieses sistemáticos de julgamento, sendo esse um fato inconsciente e não intencional no estágio de julgamentos sobre as demonstrações contábeis.

Ressalte-se que os diversos incentivos para manipular as informações contábeis não são excludentes e podem ocorrer simultaneamente em um mesmo período. Além disso, Stolowy e Breton (2004, p.21) apontam que existem poucos estudos sobre potenciais perdas através da manipulação das informações contábeis e os ganhos e perdas devem ser ponderados antes de efetuar qualquer prática discricionária.

Em sua pesquisa junto aos executivos, Graham et al (2005) identificam que os administradores estão mais interessados em atingir certas metas de lucratividade, primeiramente, para influenciar os preços das ações e sua própria riqueza via carreira profissional e reputação, tendo menor preocupação com relação aos incentivos relacionados às clausulas contratuais de dívida, risco de crédito, viabilidade política e sistema de bonificação.

\subsubsection{Formas de manipulação das informações contábeis}

Os trabalhos sobre gerenciamento de resultados na literatura corrente (JONES, 1991; DECHOW et al, 1995; BURGSTAHLER; DICHEV, 1997; HEALY; WAHLEN, 1999; MARTINEZ, 2001; BARTOV et al, 2002; BARTOV; MOHANRAM, 2004; FUJI, 2004; TUKAMOTO, 2004; ZENDERSKY, 2005) estão focados, principalmente, na manipulação do resultado contábil, através dos accruals discricionários. Essa interferência sobre os números contábeis através dos accruals pode ocorrer na escolha do momento do reconhecimento e/ou na escolha do critério de mensuração contábil (CARDOSO, 2005, p.18).

Um valor atribuído inadequadamente no processo de mensuração contábil pode 'mascarar' o verdadeiro estado econômico e financeiro da empresa, não somente através do resultado contábil, mas também nos demais itens da Demonstração de Resultado dos Exercício, bem como nos demais relatórios contábeis, como, por exemplo, na Demonstração de Fluxo de Caixa e Balanço Patrimonial.

Martinez (2001, p.1) alerta que "em contexto de assimetria de informações, há o inevitável risco de que os resultados reportados pela gestão não sejam efetivamente apresentados nos moldes esperados pelos usuários da informação contábil’. Essa possibilidade deve-se ao fato de que os administradores podem manipular os números contábeis divulgados através do seu julgamento sobre as escolhas contábeis, afetando o reconhecimento dos accruals. 
Existe, ainda, a manipulação das atividades reais da empresa com o intuito de apresentar informações contábeis mais satisfatórias, mas que não passam pelas escolhas contábeis. Isso pode ser efetuado de diversas maneiras como, por exemplo, a concessão temporária de descontos sobre o preço de venda, o envio de produtos a diversos clientes (mesmo que exista a possibilidade de inúmeras devoluções posteriores) ou uma elevação brusca do nível de produção com o intuito de reduzir os custos dos produtos vendidos através da diluição dos custos fixos.

Outra forma seria a manipulação classificatória dos elementos contábeis, a fim de distorcer a avaliação do desempenho econômico, financeiro e operacional da empresa, tendo, dessa forma, provavelmente um acentuado número de possibilidades de 'maquiagem' dos relatórios contábeis. Exemplos semelhantes seriam: a reclassificação de passivos de curto para longo prazo ou de ativo de longo para o curto prazo; ocultamento de passivos de contingência (essas práticas influenciando o Balanço Patrimonial); reclassificação de gastos de operacionais para atividades de investimentos (Demonstração de Fluxo de Caixa) e reclassificação de gasto operacional para não-operacional (Demonstração de Resultado).

Por fim, a manipulação das informações contábeis poderia ser exercida através da mensuração indevida dos elementos patrimoniais que afetam o montante dos valores contábeis, principalmente, através do Balanço Patrimonial e que não transita pelo resultado do exercício. Um exemplo seria a reavaliação de ativos com o objetivo de que a constituição da reserva reverta o valor negativo do patrimônio líquido.

Resumidamente, podem-se classificar as práticas comuns de manipulação das informações contábeis nas seguintes formas:

a) gerenciamento de resultados contábeis através dos accruals;

b) manipulação das atividades operacionais da empresa;

c) manipulação classificatória dos elementos das demonstrações contábeis.

Mas, apesar da existência dessa variedade, excetuando-se o gerenciamento de resultados através dos accruals, poucos estudos empíricos exploram as outras formas de manipulação das demonstrações contábeis (GRAMLICH et al, 2001; GORDON; JOSS, 2004; GUNNY, 2005; CARDOSO; MARTINEZ, 2006; ROYCHOWDHURY, 2006). 


\subsubsection{Gerenciamento de resultados contábeis através dos acccruals}

A grande ênfase ao gerenciamento dos resultados contábeis dentro das pesquisas pode ser explicada pela importância dada ao lucro do período pelos diversos usuários da Contabilidade e, freqüentemente, utilizada como variável essencial no modelo decisório para alocação de recursos pelos investidores.

Segundo Beneish (2001, p.3), as pesquisas sobre gerenciamento de resultados baseados em acccruals são mais comuns, devido às seguintes razões:

a) os accruals são frutos da aplicação das normas contábeis e, se os resultados são gerenciados, é mais provável que isto ocorra através dos accruals do que nos componentes dos resultados que tenham influência no fluxo de caixa;

b) analisando os accruals reduzem-se os problemas associados à incapacidade de mensurar os efeitos das várias escolhas contábeis dentro do resultado;

c) se o gerenciamento de resultados é um componente não observado dos accruals, é menos provável que os investidores possam detectar o efeito da manipulação das informações contábeis.

As acumulações (accruals) seriam todas aquelas contas de resultados que entraram no cômputo do lucro, mas não implicam necessariamente movimentação de disponibilidades, e que para a literatura internacional, seria a diferença entre o lucro líquido e o fluxo de caixa. (MARTINEZ, 2001, p. 16).

Porém, o accrual é um conceito contábil empregado para atender ao regime de competência (accruals basis) e que busca mensurar o resultado no sentido econômico, independentemente da realização financeira das transações e eventos. Segundo Eliseu Martins (1999), com algumas exceções, a diferença entre accruals basis e cash basis (fluxo de caixa) é uma questão temporal.

Com o intuito de desenvolver uma metodologia para analisar o gerenciamento de resultados, tem-se necessidade de separar os accruals em:

a) discretionary accruals (acumulações discricionárias), que são artificiais e teriam como objetivo somente manipular o resultado contábil e

b) nondiscretionary accruals (acumulações não-discricionárias), que são inerentes às atividades da empresa.

Para isso, alguns modelos operacionais de accruals agregados foram desenvolvidos considerando que o componente discricionário seria uma proxy do gerenciamento de resultados (HEALY, 1985; JONES, 1991; DECHOW et al, 1995 e KANG; 
SIVARAMAKRISHNAN, 1995). Apesar de a maioria das pesquisas empíricas sobre gerenciamento de resultados utilizarem os modelos baseados em accruals agregados, esses são criticados por falharem na distinção do componente gerenciado e componente nãogerenciado (McNICHOLS, 2000; BENEISH, 2001). Para Bartov e Mohanram (2004, p.919), os accruals discricionários agregados não são considerados proxies adequadas para identificar a existência de gerenciamento de resultados nos relatórios contábeis.

Uma das vantagens em utilizar os accruals especificos é que o pesquisador pode desenvolver e implementar intuitivamente fatores importantes que influenciam o comportamento das acumulações, explorando seus conhecimentos sobre as atividades da empresas e sobre as normas contábeis. (McNICHOLS, 2000, p.333). Entretanto, o mesmo autor alerta que os estudos sobre essa abordagem requerem maiores aprofundamentos em setores específicos e limitam a generalização das evidências encontradas nos estudos.

Além do mais, os métodos de accruals simples ou específicos têm como principais desvantagens:

a) O gerenciamento de resultados pode ser detectado somente se o accrual analisado é gerenciado;

b) Os administradores, provavelmente, não gerenciam os números contábeis através de um único tipo de accrual;

c) Um accrual especifico pode ser mais facilmente influenciado por outros fatores do que as acumulações totais, como, por exemplo, as receitas podem ser afetadas pela conjuntura econômica ou pela política de créditos da empresa.

Outra metodologia alternativa de análise seria através da distribuição de freqüência dos resultados, verificando comportamentos anormais em torno de pontos de referência, como, por exemplo: resultado nulo, variação do lucro no período e distorção entre o resultado contábil e a expectativa dos analistas financeiros. Entretanto, a dificuldade dessa metodologia está em grande parte na escolha dos pontos de referências, além de não identificar a magnitude do gerenciamento de resultados.

Verifica-se que o gerenciamento de resultados pode ser dividido em alguns padrões como (SCOTT, 2003, p.383):

a) Taking a bath: Esse padrão consiste na diminuição dos resultados correntes ou na divulgação de prejuízos contábeis, normalmente, em períodos de reorganização da empresa e/ou mudança da cúpula administrativa. A intenção é de que, no primeiro momento, a gestão da empresa reconheça o maior volume de possíveis perdas ainda não 
evidenciadas, 'limpando' nas demonstrações contábeis para aumentar as probabilidades de divulgação de lucros contábeis no futuro. No segundo momento, a administração começa evidenciar melhorias no desempenho da empresa, fazendo com que os usuários da informação avaliem a atual gestão como de boa qualidade.

b) Income minimization (diminuição dos resultados): Semelhante ao taking a bath, mas menos extrema. Essa prática é escolhida pelas firmas que são mais politicamente monitoradas, em períodos de alta lucratividade ou mesmo por motivações tributárias.

c) Income maximization (maximização dos resultados): Busca atingir resultados elevados conforme os interesses dos gestores da empresa, e estão relacionados, normalmente, ao plano de remuneração dos administradores, debt covenants, etc.

d) Income smoothing (suavização dos resultados): Essa forma reduz a volatilidade dos resultados reportados, pois os investidores aversos ao risco preferem que os lucros sejam estáveis. Além disso, a income smoothing pode ser utilizada para apresentar uma persistência de elevação dos lucros.

Outra abordagem para analisar o gerenciamento de resultados é através do Balanço Patrimonial. A articulação entre a Demonstração de Resultados e o Balanço Patrimonial assegura que accruals refletidos nos resultados sejam, também, nos ativos e passivos da empresa. A utilização de accruals discricionários implica que os ativos líquidos (total dos ativos menos o total dos passivos exigíveis) fiquem mensurados temporariamente a valores que não refletem a verdadeira realidade econômica da empresa.

Com base no Balanço Patrimonial, Barton e Simko (2002) utilizaram informações sobre os elementos patrimoniais como proxy para mudanças de critérios contábeis influenciadas pelos administradores, principalmente, as que estão relacionadas às atividades operacionais. Os referidos autores (2002, p.20) apresentam evidências de que a probabilidade de grandes surpresas positivas e negativas nos resultados decresce com o tamanho em que os ativos líquidos são superavaliados no Balanço Patrimonial, ou seja, empresas com grande volume de recursos em ativos operacionais (tomando como base o Balanço Patrimonial do início do período) ponderados pelas receitas são menos sujeitas a apresentar surpresas em seus resultados. 


\subsubsection{Manipulação das atividades operacionais da empresa}

Gunny (2005, p.2) explica que a manipulação das atividades operacionais (real earnings management) ocorre quando os administradores desenvolvem ações que desviam da melhor decisão (the first best practice) para ajustar os resultados reportados a suas necessidades. Roychowdhury (2006, p.336) define essa forma de gerenciamento como ações da administração que desviam das práticas normais do negócio com o objetivo principal de atingir certos níveis de resultados.

Os administradores podem manipular as atividades operacionais durante o ano, a fim de atingir certas metas de desempenho. Roychowdhury (2006, p.336) afirma que a manipulação das atividades reais afeta o fluxo de caixa da empresa e pode também afetar os accruals discricionários, e finaliza o trabalho tecendo críticas às metodologias focadas na detecção de accruals anormais que não segregam a manipulação das acumulações da manipulação das atividades reais. Além disso, o mesmo autor (2006, p.336) observa que os estudos que focam a manipulação das atividades reais têm se concentrado, principalmente, nas atividades de investimentos, como, por exemplo, na redução dos gastos com pesquisa e desenvolvimento, sem explorar inúmeras possibilidades dessa forma de manipulação.

A manipulação das atividades operacionais depende de como a transação é delineada. Como exemplos dessa forma de manipulação, têm-se:

a) aumento das receitas pela aceleração do processo de vendas e/ou geração de vendas insustentáveis através de aumento dos descontos (temporário) sobre o preço ou diminuição das restrições de crédito aos clientes;

b) diminuição das receitas pela postergação do envio de vendas já realizadas;

c) redução dos custos dos produtos vendidos através do aumento dos níveis de produção (economia de escala), fazendo com que os resultados contábeis aumentem no período e

d) redução dos gastos com pesquisas e desenvolvimento, treinamento de pessoal, manutenção do parque fabril.

Entre os principais motivos para empregar a manipulação das atividades operacionais, ao invés da manipulação dos accruals estão (GUNNY, 2005, p.2):

a) a escolha contábil com relação aos accruals é de maior risco de fiscalização e monitoramento pelos auditores e organismos reguladores da Contabilidade e

b) flexibilidade limitada para manipular os accruals. 
Porém, a manipulação das atividades reais pode afetar negativamente o valor da empresa, devido à possibilidade de influenciar os fluxos de caixa nos períodos subseqüentes, como, por exemplo, pelos descontos anormais concedidos aos clientes implicando em menor margem de lucro nas vendas futuras, desde que os fornecedores não ofereçam os mesmos descontos proporcionais à empresa.

Além disso, Zang (2005) estabelece que as decisões sobre manipulação das atividades reais precedem o gerenciamento de resultados através dos accruals discricionários, mas nem sempre isso é possível, pois, em certas circunstâncias econômicas podem acarretar em perdas econômicas e financeiras de caixa, como, por exemplo, quando possuem efeitos tributários. Tal limitação faz com que o administrador avalie o trade-off entre as duas práticas de manipulação simultaneamente, a fim de equacionar os seus benefícios e prejuízos.

Ewert e Wagenhofer (2005, p.1102) esclarecem que o gerenciamento contábil de resultados se refere à forma como as normas da Contabilidade são aplicadas para reconhecer e mensurar determinado evento ou transação, enquanto o gerenciamento das atividades operacionais afeta o momento e/ou a estrutura da transação real. Cabe ressaltar que a manipulação das atividades reais é muito mais difícil de ser inibida do que o gerenciamento através das escolhas contábeis.

\subsubsection{Manipulação classificatória dos elementos das demonstrações contábeis}

A manipulação das informações contábeis através da reclassificação dos elementos contidos nas demonstrações contábeis é pouco discutida pela literatura acadêmica (GRAMLICH et al, 2001; GORDON; JOOS, 2004). A reclassificação de elementos das demonstrações contábeis tem impacto na mensuração dos componentes dos ativos, passivos, patrimônio líquido, receitas e despesas e, por conseqüência, prejudicam a análise da liquidez, endividamento, rentabilidade e alavancagem da empresa.

Gramlich et al (2001) analisam a reclassificação de certas obrigações de curto prazo para o passivo corrente de longo prazo e o retorno ao passivo corrente nos anos subseqüentes. Através desse estudo, foram observadas evidências de que reclassificação e sua reversão estabilizavam (smooth) os indicadores de liquidez e alavancagem, sendo que essa prática está altamente correlacionada com a deterioração do índice de liquidez corrente quando comparado ao período anterior e/ou indicadores do setor econômico. Outra evidência 
importante relatada pelos autores é que tal prática tem sido utilizada com sucesso para evitar violações às cláusulas contratuais.

Gordon e Joos (2004) pesquisaram como os administradores britânicos mensuram, de forma oportunista, o diferimento de tributos para gerenciar os indicadores de alavancagem. Os resultados da pesquisa sugerem que os administradores mensuram oportunistamente o diferimento no Balanço Patrimonial, mas não na Demonstração de Resultados, portanto essa prática influencia fortemente a alavancagem da empresa.

Outra possibilidade de manipulação seria na classificação dos títulos híbridos (hybrid securities) que não possuem uma classificação bem definida no passivo ou patrimônio líquido, devido às suas próprias características e que apresentam um elevado grau de incerteza quanto à natureza econômica. Stolowy e Breton (2004, p. 29) comentam que existe a necessidade de maiores pesquisas sobre manipulação do Balanço Patrimonial (Balance Sheet Management), principalmente, para itens fora dessa demonstração contábil (off-balance sheet).

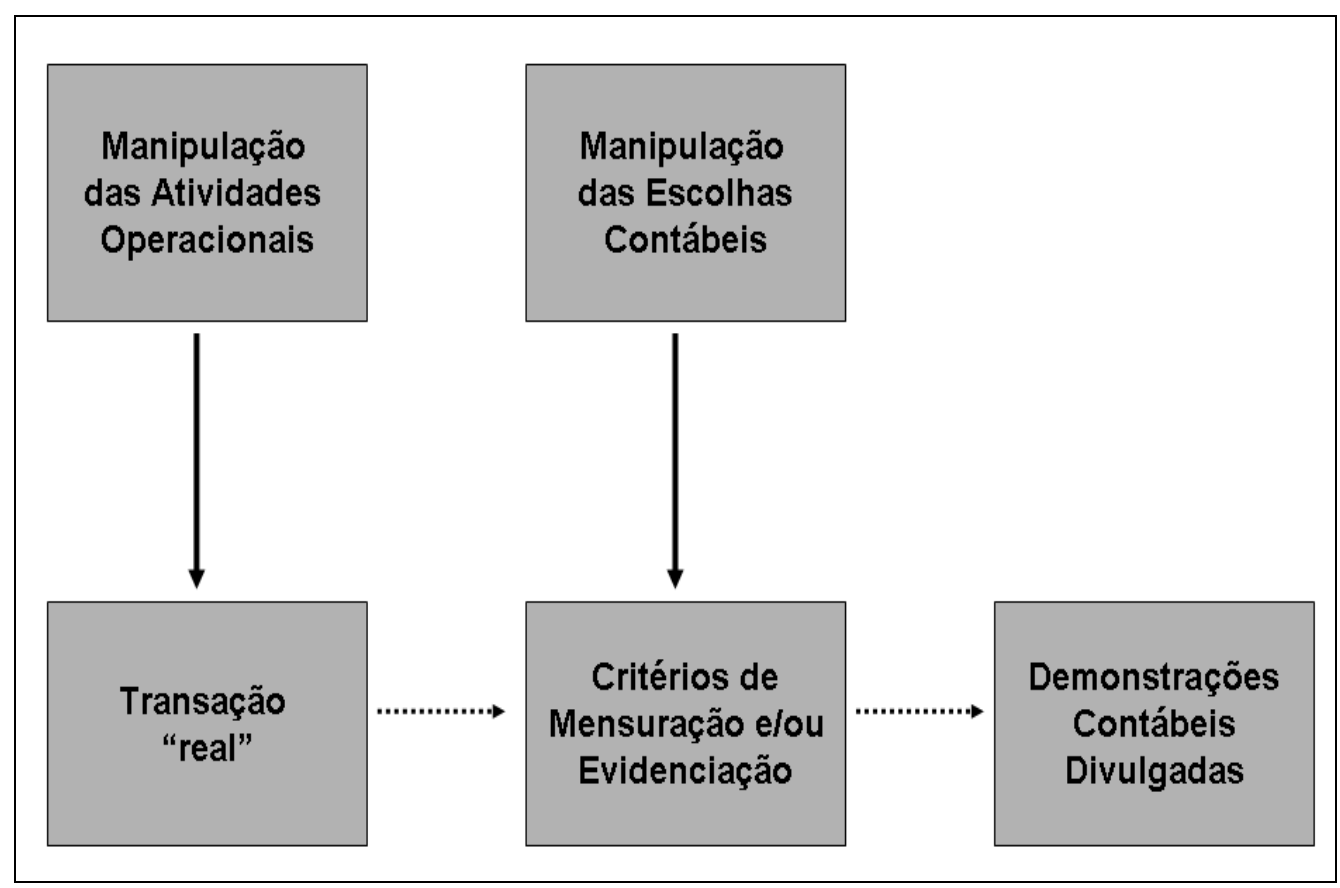

Ilustração 2 - Manipulação das Informações Contábeis: Atividades Operacionais e Escolhas Contábeis

Fonte: McKee, 2005, p.15 (adaptado)

Assim, pode-se considerar que as empresas têm a oportunidade de empregar, conjuntamente, várias formas e tipos de manipulação das informações contábeis, como, por exemplo, o 
emprego das atividades reais e, posteriormente, as escolhas contábeis, com o intuito de reportar a informação da forma desejada, conforme a Ilustração 2.

\subsubsection{Influência das características organizacionais e institucionais}

A manipulação das informações contábeis não depende somente das normas e práticas contábeis e dos incentivos e oportunidades para atitudes discricionárias. O contexto organizacional e institucional em que o sistema contábil está inserido influencia fortemente as escolhas contábeis, como discutido anteriormente neste trabalho.

Dentre os diversos fatores institucionais e organizacionais que podem influenciar a manipulação das informações contábeis destacam-se:

a) estrutura societária e mercado de capital;

b) proteção ao investidor (não controlador);

c) nível de evidenciação obrigatória;

d) diferenças nas normas contábeis entre os diversos países e

e) alinhamento do sistema contábil e tributário.

Os usuários interessados nas companhias abertas e fechadas demandam, de forma diferente, as informações contábeis. O mercado de capitais, no qual são negociados os títulos e valores mobiliários das companhias abertas, geram uma demanda maior de informações úteis para a avaliação e monitoramento da firma (BURGSTAHLER et al, 2006, p.987). Por não ter acesso privado às informações, os usuários externos da companhia devem acreditar nas informações reportadas pela administração.

Mas caso os fornecedores de capitais (investidores) considerem que as informações prestadas são de baixa qualidade, podem dificultar ou até mesmo evitar o fornecimento de recursos financeiros necessários para que as empresas executem normalmente suas atividades operacionais, financeiras e de investimentos. Assim, diante da possibilidade de "fuga" de capitais, o administrador tem fortes incentivos para fornecer informações contábeis que conduzam os usuários externos a uma boa avaliação do desempenho econômico e financeiro da empresa.

Burgstahler et al (2006, p.985) apresentam evidências de que os países com mercado acionário mais desenvolvido possuem menor nível de gerenciamento de resultados e as companhias fechadas apresentam maiores níveis de gerenciamento de resultados do que as 
abertas, evidenciando, assim, que os diversos tipos de sociedades respondem diferentemente aos fatores institucionais. Assim concluem que o gerenciamento de resultados prevalece mais nas companhias fechadas do que nas abertas e, portanto, a hipótese de que o mercado acionário prejudica a qualidade da informação contábil não é verificada. Esses autores sugerem que mercados de capitais fortes e de financiamento sem favorecimento ( $\mathrm{arm}^{\mathrm{s}} \mathrm{s}$ leght financing) fornecem números com maior conteúdo informacional.

Portanto, o mercado de capitais demanda maior qualidade das informações contábeis das empresas que operam nesse ambiente. As companhias fechadas, bem com os demais tipos de sociedades, têm, relativamente, menores incentivos para fornecer informações contábeis com melhor qualidade, pois a sua estrutura de capital está concentrada em poucos acionistas e podem eficientemente comunicar-se com os seus acionistas ou principais credores através de canais privados de comunicação, como no caso da Alemanha, França e Itália. A esse respeito, Ball e Shivakumar (2005, p.84) explicam que as companhias fechadas apresentam maior tendência para resolver os seus problemas de assimetria informacional internamente do que as companhias abertas.

A Contabilidade, também, está sujeita à escrutinação pela auditoria externa, conselhos internos, órgãos ou agências reguladoras, fiscalização tributária que buscam garantir a qualidade da informação contábil reportada aos seus usuários. É de se esperar que as empresas que exerçam atividades reguladas e fiscalizadas por órgãos como Banco Central do Brasil (BACEN), Agência Nacional de Energia Elétrica (ANEEL), Agência Nacional de Telecomunicações (ANATEL) e Agência Nacional de Saúde Suplementar (ANS) apresentem maior qualidade das informações divulgadas ao mercado, por serem mais monitoradas através dos seus relatórios contábeis. O monitoramento por essas entidades tem como papel principal a preocupação com a veracidade das informações divulgadas, controle das atividades exercidas pelas empresas do setor e elaboração de políticas econômicas.

Com relação ao sistema legal, pode-se considerar que, sem um adequado cumprimento ou execução (enforcement) legal, as legislações permanecem largamente ineficientes e, conseqüentemente, em países com fraco sistema legal podem sofrer maiores conseqüências da discricionariedade sobre as regras contábeis. McLeay (2005, p.732) expõe que o gerenciamento de resultados é mais acentuado em países em que a proteção legal ao investidor é mais branda. Considera-se, então, que um sistema normativo de Contabilidade mais restritivo reduz os problemas originados pelo comportamento discricionário dos administradores (McLEAY, 2005; EWERT; WAGENHOFER, 2005). 
Dentro do ambiente normativo do sistema contábil, pode-se avaliar o comportamento discricionário diante do desenvolvimento de normas contábeis baseadas em regras ou em princípios. Esse assunto novamente voltou a ser discutido com maior intensidade quando da aprovação da lei Sarbanes-Oxley no Estados Unidos. A seção 108 da lei Sarbanes-Oxley propôs a substituição do sistema contábil baseado em regras para o baseado em princípios.

Existem várias visões sobre o que seja um conjunto de normas contábeis baseadas em princípios ou em regras (NELSON, 2003; SCHIPPER, 2003; VICENT, 2003; ELIFOGLU; FITZSIMONS, 2003). Em síntese, o sistema contábil baseado em princípios é caracterizado pelo fato de que as normas emanadas desse sistema estabelecem somente diretrizes básicas, buscando a melhor expressão da realidade econômica e financeira e a essência da transação ou evento econômico é preferível à forma jurídica. Por outro lado, no sistema baseado em regras, as normas descem aos detalhes da operacionalização dos procedimentos contábeis, observando, pragmaticamente, os termos da norma e a evidenciação básica da realidade da empresa, pautada, principalmente, nas exigências legais, prevalecendo a forma jurídica nas informações contábeis e não a essência econômica.

Diante dessa distinção, espera-se ques no sistema baseado em princípios, o profissional contábil utilize, com maior freqüência, o juízo de valor e tenha maior grau de liberdade para apresentar informações contábeis. Entretanto, no sistema baseado em regras, o profissional cumpre exatamente o que está expresso na norma, de forma que os procedimentos adotados para mensuração e evidenciação contêm vários testes de percentagem que podem ser utilizados, inadequadamente, na elaboração das demonstrações contábeis como meio para cumprir a forma da norma, mas não atendendo à sua essência.

A Securities and Exchange Commission (SEC) emitiu, em 25 de julho de 2003, um relatório sobre o assunto intitulado Study pursuant to section 108(d) of the Sarbanes-Oxley act of 2002 on the adoption by the United States financial reporting system of a principles-based accounting system, que apresenta diversos pontos a serem analisados quando da implementação de um novo sistema contábil (ELIFOGLU; FITZSIMONS, 2003).

Nesse estudo, a SEC descreve as imperfeições existentes quando as normas são baseadas em princípios (exclusivamente) ou em regras, assim não recomenda nenhuma das duas abordagens e, sim, a adoção do sistema contábil baseado em objetivos, segundo o qual os objetivos das normas contábeis devem ser claramente definidos e suficientemente detalhados. Segundo a SEC (2003), a norma baseada em objetivos deve ter uma estrutura consistente para ser, devidamente, operacionalizada e evitar os testes de percentagens, assim as empresas podem alcançar a conformidade técnica. 
Um aspecto extremamente delicado na concepção dada pelo sistema contábil pretendido pelo FASB seria a necessidade por parte dos contadores e auditores de exercer o julgamento profissional adequado na aplicação das normas contábeis e a consistência com a substância econômica da transação e/ou evento. Esse julgamento será necessário devido, inclusive, ao afastamento das regras detalhadas, testes de percentagens, exceções e tratamentos alternativos, buscando ampliar a percepção de consistência e comparabilidade das informações contábeis, mas que pode resultar em "falsa realidade", prejudicando a própria comparabilidade, pois estaria baseado em outra substância.

Outro aspecto comportamental da adoção da abordagem proposta é o tratamento a ser dado às exceções na contabilidade, podendo conduzir de forma intencional para reduzir a volatilidade dos resultados (smoothing income), evitar a apresentação de perdas contábeis, minimizar os erros das previsões dos analistas financeiros, entre outros incentivos.

Observando somente a promulgação da Lei Sarbanes-Oxley, Cohen et al (2005) realizaram um estudo sobre o gerenciamento de resultado e o poder informativo do anúncio de resultados nos períodos antes e após a aprovação da Lei Sarbanes-Oxley, e concluíram que houve um declínio significativo nas práticas de manipulação da informação contábil após a Lei. Entretanto, essa evidência tem que ser observada com cautela, porque a diminuição do comportamento oportunista pode ser uma resposta temporária aos escândalos ou outros eventos concorrentes. Com relação ao poder preditivo dos números contábeis, os autores evidenciaram que não houve mudança significativa.

O auditor tem papéis contraditórios em sua atuação profissional. Primeiro, procura satisfazer o cliente e, segundo precisa evitar riscos de terceiros. A auditoria reduz a assimetria informacional através do exame e da validação das informações contábeis reportadas. Esperase que a eficácia da auditoria e sua capacidade em restringir a manipulação dos números contábeis variem conforme a qualidade da auditoria. Nessa linha de raciocínio, Becker et al (1998) examinaram a qualidade da auditoria e a prática de gerenciamento de resultados e demonstraram que os clientes das grandes empresas de auditoria, denominadas na época de Big Six, apresentavam menor nível de accruals discricionários do que as demais empresas. As mesmas evidências sobre a influência da auditoria sobre o gerenciamento de resultados são relatadas por Piot (2005) no contexto das empresas francesas.

Buscando maior compreensão sobre a influência da auditoria, DeFond e Subramanyam (1998) encontram evidências de que o volume de accruals discricionários decresce no último ano antes da troca de empresa de auditoria. Martinez (2001, p.146), dentro do contexto brasileiro, evidencia que as empresas de auditoria nacionais são mais tolerantes ao gerenciamento de 
resultados do que as empresas denominadas Big 5. Portanto, a prestação de serviços por uma grande empresa de auditoria pode restringir o comportamento oportunista.

Diante das evidências da participação da empresa de auditoria Arthur Andersen no escândalo financeiro da Enron em 2001, os órgãos responsáveis pela regulação contábil de cada país buscaram mais fortemente fortalecer a independência das empresas de auditoria, como, por exemplo, inibir que uma empresa de auditoria preste outros serviços ao mesmo cliente em que ela esteja realizando os serviços de auditoria. Por exemplo, a CVM através da Instrução $\mathrm{n}^{\circ}$ 381/2003 obrigou que as companhias abertas brasileiras divulguem os honorários pagos a seus auditores externos por outros serviços. O objetivo principal de norma é verificar se há independência financeira da empresa de auditoria em relação aos seus clientes.

Ewert e Wagenhofer (2005, p.1101) afirmam que os organismos que emitem normas contábeis, normalmente, consideram o gerenciamento de resultados como indesejável e buscam inibir a prática discricionária dos administradores sobre os números contábeis, através de padrões mais restritivos.

Adicionalmente, deve-se considerar que os investidores e credores comparam as demonstrações contábeis entre as empresas, no mesmo setor ou ramo de negócio, com o objetivo de avaliar ao desempenho e o valor da firma. Bagnoli e Watts (2000, p.377) afirmam que as empresas manipulam as suas informações influenciadas pelos relatórios contábeis dos concorrentes. Além das questões relacionadas à captação de recursos, os administradores, normalmente, estão interessados nos números contábeis dos concorrentes, pois sua remuneração pode estar relacionada a determinadas metas pautadas nessas demonstrações.

Outro ponto a ser considerado nos estudos sobre manipulação das informações contábeis é a questão ética. Hendriksen e Van Breda (1999, p. 149) consideram que, atualmente, "a ética é invariavelmente tratada em termos de como uma pessoa deve comporta-se - e não o faz", enquanto Schroeder et al (2001, p. 527) consideram que ética e moral não são termos semelhantes: "Em geral, ética [...] é o estudo da fontes morais, enquanto que fontes morais [...] são padrões que os indivíduos observam em sua conduta diária." ${ }^{27}$

Em uma abordagem positiva, "a ética pode ser um estudo dos costumes que realmente determinam o comportamento das pessoas". (HENDRIKSEN; VAN BREDA, 1999, p. 149). Essa percepção de costumes torna-se relevante nos estudos sobre a informação contábil e as características institucionais e organizacionais, pois possibilita novas explicações sobre a realidade além daquelas oferecidas pela teoria econômica. Nesse sentido, deve-se considerar

\footnotetext{
${ }^{27}$ Tradução livre de: "In general, ethics [...] is the study of moral issues, whereas morals [...] are standards that individuals observe in their daily conduct."
} 
que as decisões empresarias são afetadas pelos costumes sociais, pois as escolhas individuais são limitadas pelos costumes do ambiente em que o agente está inserido.

“Essas limitações geralmente resultam de decisões baseadas em questões a respeito do que é certo ou justo" (HENDRIKSEN; VAN BREDA, 1999, p. 149), portanto, a abordagem ética pode apresentar um suporte teórico para o comportamento, oportunístico ou não, dos gestores. Porém, uma das dificuldades para analisar o comportamento oportunístico dos gestores é que não existe uma definição aceita do que é a manipulação das informações contábeis (ou gerenciamento de resultados).

\subsection{Desenvolvimento de modelos na pesquisa analítico-empírica em Contabilidade}

A pesquisa em Contabilidade, desde meados da década de 1960, vem evoluindo fortemente através da abordagem positiva. Essa abordagem busca compreender os fenômenos econômicos, em particular, pretende explicar e prever as escolhas contábeis, o comportamento dos vários indivíduos e a alocação eficiente dos recursos disponíveis na economia diante das informações divulgadas pela Contabilidade. Sua relevância está no sentido de que, “o entendimento do que é realizado na prática serve como base fundamental para a previsão de comportamentos futuros." (LOPES, 2001, p.26)

As pesquisas sob o prisma da abordagem positiva podem ser classificadas, resumidamente, segundo a sua natureza, em: pesquisa analítica, pesquisa comportamental e pesquisa empírica (RIAHI-BELKAOUI, 2000, p.361-371).

A pesquisa analítica tem como foco a modelagem (matemática) dos fenômenos contábeis e econômicos com objetivo de gerar proposições testáveis empiricamente. Os principais campos de atuação dessas pesquisas estão ligados a estudos sobre a relação entre a informação contábil e o mercado de capitais, bem como sobre o papel da informação contábil na resolução dos problemas de agência.

A pesquisa comportamental emprega os conhecimentos das Ciências Comportamentais para examinar o julgamento e a tomada de decisões dos contadores, administradores, auditores e demais usuários diante da informação contábil.

A pesquisa empírica na Contabilidade estuda, principalmente, as diversas relações entre as informações contábeis e comportamento dos usuários da Contabilidade em relação aos fatores institucionais e organizacionais, o poder preditivo e influência da informação no ambiente 
econômico. Esses estudos testam hipóteses através de métodos estatísticos e devem estar respaldados por teorias contábeis e econômicas subjacentes e, em particular, nas teorias e modelos desenvolvidos na pesquisa analítica. Entretanto, nada impede que uma pesquisa empírica realinhe (ajuste) o modelo analítico anteriormente utilizado, diante de evidências que comprovem os benefícios do ajustamento sobre a especificação e o poder preditivo.

Um produto da pesquisa analítica seria o modelo desenvolvido através de um processo de modelagem. Modelagem refere-se à representação de um conceito ou processo, que enquanto analítico, se reporta para à dedução lógica (DEMSKI, 2006, p.1).

Mazzon $(1978$, p.7) afirma que as diversas áreas do conhecimento "têm utilizado modelos com o objetivo de analisar e prever o comportamento de um determinado fenômeno, estrutura ou processo de estudo. Um modelo é, portanto uma forma de obtenção de conhecimento." Portanto, pode-se considerar que o objetivo da modelagem é lançar luz sobre a questão de pesquisa.

O relacionamento entre os fatores (variáveis) relevantes fornece uma forma matemática ao conjunto de premissas analíticas respaldadas ou uma teoria subjacente, formando o modelo. Segundo Chiang e Wainwright (2006, p.7), “um modelo econômico é apenas uma estrutura teórica e não há razão inerente por que deva ser matemático. Contudo, se o modelo for matemático, usualmente consistirá em um conjunto de equações elaborado para descrever a estrutura do modelo."

Porém, ante a complexidade das relações entre o objeto de estudo e o ambiente, o modelo é uma representação simplificada da realidade, uma abstração, portanto, uma proxy subjetiva do fenômeno estudado.

Para Wagenhofer (2004, p.6), os modelos analíticos em Contabilidade têm origem na teoria econômica. Pode-se considerar que esses modelos são representações do fenômeno contábil 'real' e, por limitações diversas, não observam o cenário de maneira completa ou ignoram alguns aspectos, confiando em pressupostos nem sempre realísticos e no comportamento racional dos indivíduos.

A conseqüência dessa falha é que, não esporadicamente, os resultados das pesquisas são conduzidos por pressupostos restritivos, tornando-se altamente específicos para um ambiente, não podendo ser generalizado e, portanto, perder sua utilidade.

Observando os trabalhos científicos em Contabilidade e outras áreas do conhecimento científico, a representação das relações dos diversos agentes econômicos tem sido normalmente delineada por ações de interesses próprios, na qual maximiza o valor presente das utilidades econômicas pessoais, ou seja, a sua riqueza. Assume-se que o comportamento 
racional das escolhas contábeis é governado pela função utilidade e a ação com maior utilidade esperada é a preferível do indivíduo (RIAHI-BELKAOUI, 2000, p. 286). Porém, o indivíduo não age sempre com base na racionalidade econômica.

Para Demski (2006, p.6), o modelo está bem desenvolvido para responder à questão, quando permite que as proposições surjam naturalmente no modelo. Entretanto, quando são levantadas hipóteses que se apresentam contrárias às proposições da teoria analisada, origina $(\mathrm{m})$-se teoria $(\mathrm{s})$ concorrente( $\mathrm{s})$ à primeira.

Watts e Zimmerman (1986, p.9) afirmam que:

\begin{abstract}
A teoria consiste de duas partes: as suposições, incluindo as definições das variáveis e a lógica que as relaciona, e o conjunto de hipóteses substantivas. As suposições, definições e lógica são usadas para organizar, analisar e compreender o fenômeno empírico de interesse, enquanto que as hipóteses são as predições geradas a partir das análises. ${ }^{28}$
\end{abstract}

Uma pergunta poderia ser levantada: Por que existem teorias e modelos concorrentes? A explicação é porque as teorias e, conseqüentemente, os modelos delas originados, são incompletos e não conseguem capturar toda a realidade. Assim, podem existir inúmeras teorias alternativas que expliquem o mesmo fenômeno.

Mas, diante de teorias imperfeitas, qual seria aquela de maior sucesso ou sobrevivente? Considerando que a preocupação tem sido a utilidade da informação contábil para o usuário, segundo Watts e Zimmerman (1986, p.11), o valor da teoria dependerá dos custos associados ao erro de predição para o usuário e a utilização do modelo. Logicamente, se existe somente uma teoria disponível, essa será utilizada enquanto seus custos forem menores do que os custos do uso do senso comum ou até que se desenvolva outra teoria que apresente maior beneficio marginal.

Watts e Zimmerman (1986, p.12), ainda, defendem que as teorias alternativas são importantes já que levam aos pesquisadores a testarem certas circunstâncias, em que elas podem diferentemente explicar o fenômeno e, por fim, verificar a melhor especificação em tais situações.

Se o fenômeno contábil pesquisado, bem como suas hipóteses e resultados empíricos, forem de interesse dos agentes econômicos, outros pesquisadores efetuarão novos testes em relação ao problema de pesquisa com o objetivo de aperfeiçoar a metodologia do pesquisador original e, na medida do possível, aplicando-a em outros fenômenos similares, descrevendo e testando hipóteses alternativas para os fenômenos. A teoria, por si própria, mudará e se desenvolverá

\footnotetext{
${ }^{28}$ Tradução livre de: "A theory consists of two parts: the assumptions, including the definitions of variables and logic that relates them, and the set of substantive hypotheses. The assumptions, definitions, and logic are used to organize, analyze, and understand the empirical phenomena of interest, while the hypotheses are the predictions generated from the analysis."
} 
com os resultados desses esforços, podendo inclusive ocorrer que a interpretação corrente dos resultados da pesquisa seja totalmente diferente da interpretação original.

Nesse cenário, o objetivo da utilização do modelo analítico é fornecer uma estrutura metodológica com maior rigor cientifico para as pesquisas contábeis, em relação aos pressupostos assumidos e a construção lógica das idéias e a análise dos resultados obtidos. Observa-se, então, que o desenvolvimento e a posterior aplicação dos modelos é uma necessidade para a evolução da pesquisa cientifica.

Cabe ressaltar que, na pesquisa, o termo 'modelo' pode ter significados e conotações diferentes, podendo ser analisado como modelo conceitual e modelo operacional.

O domínio conceitual da realidade começa através de idealizações, ou seja, pela criação de um objeto-modelo ou modelo conceitual de uma coisa ou de um fato, assim, um modelo conceitual é uma representação de um objeto, ora perceptível, ora imperceptível, sempre esquemática parcial e, sob certos aspectos, convencional. Estabelece, em termos amplos, a definição de um particular problema que será resolvido; especifica o domínio das variáveis que poderão ser usadas e define essencialmente a própria natureza do problema. (MAZZON, 1978, p.11-12).

No modelo conceitual, o pesquisador busca analisar a questão do problema, especificando as relações entre as variáveis que explicam o fenômeno contábil, baseado em uma teoria subjacente. Mas, Mazzon (1978, p.12) afirma que se torna necessário a definição de "um modelo formal ou operacional que procure testar as preposições contidas na teoria." A construção de um modelo operacional é importante para que se possam testar as proposições oriundas do modelo conceitual e da teoria subjacente. Resumidamente, o modelo operacional é uma forma de instrumentalização do modelo conceitual.

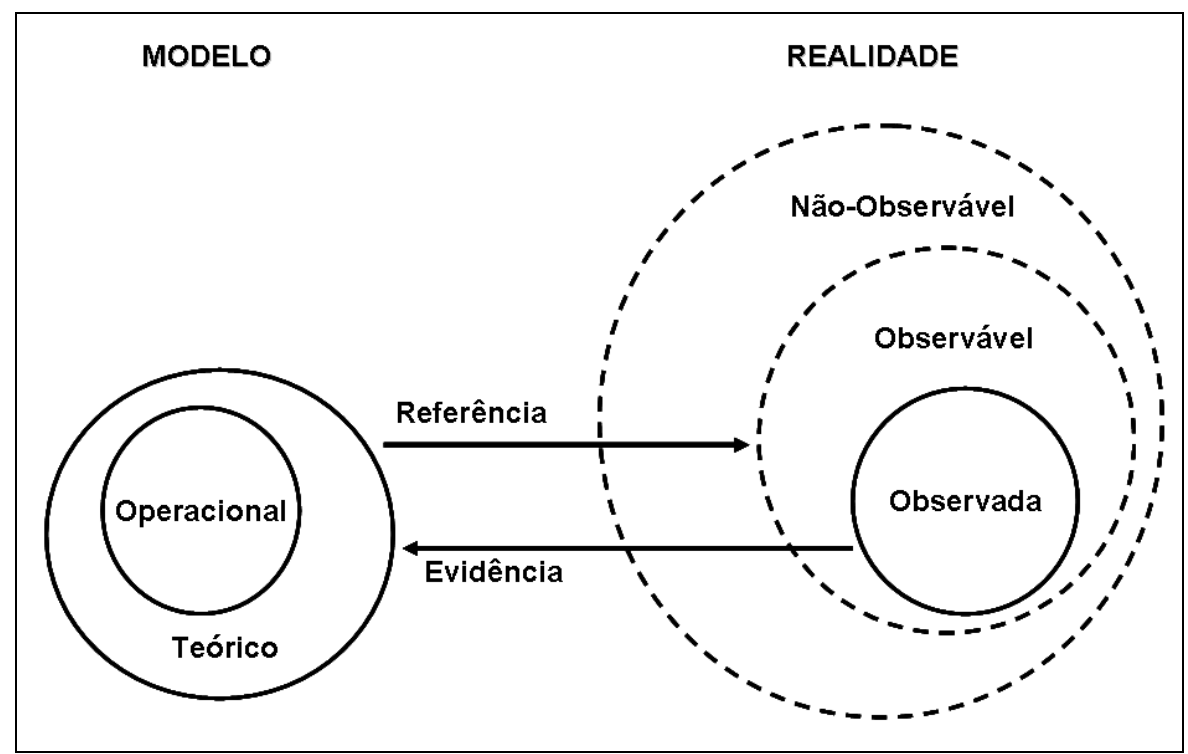

Ilustração 3 - Relação entre modelo e realidade Fonte: Mazzon, 1978, p.17 (adaptado) 
Nota-se que modelos teóricos e operacionais apresentam referências teóricas que devem ser verificáveis na realidade observável. Entretanto, no processo de modelagem deve-se ter a consciência de que os modelos não incorporam a realidade não-observável. A realidade observada nas pesquisas, por meio dos modelos operacionais, apresenta evidências que corroboram ou não a teoria e o modelo conceitual proposto.

No caso de a pesquisa refutar as hipóteses levantadas, a explicação pode estar no fato de que os modelos teóricos e/ou operacionais utilizados não captam fatores relevantes contidos na realidade não-observável. A conseqüência, nem sempre imediata, dessa negativa é uma reflexão sobre a teoria estabelecida para o fenômeno, o aperfeiçoamento dos modelos teóricos e operacionais, ou o desenvolvimento de novos modelos que pretendam representar melhor a realidade, incorporando parte daqueles fatores, até então, não-observáveis (Ilustração 3).

Outro fator que leva, em particular, ao aperfeiçoamento ou à criação de novos modelos teóricos e operacionais é o fraco poder de explicação dos modelos utilizados para retratar o fenômeno estudado.

Mazzon $(1978$, p.18) afirma que o fenômeno "pode ser representado através de modelos não equivalentes, dependente, dentre outros fatores, da disponibilidade de informações, das ferramentas analíticas à disposição do pesquisador e dos objetivos que se pretende atingir."

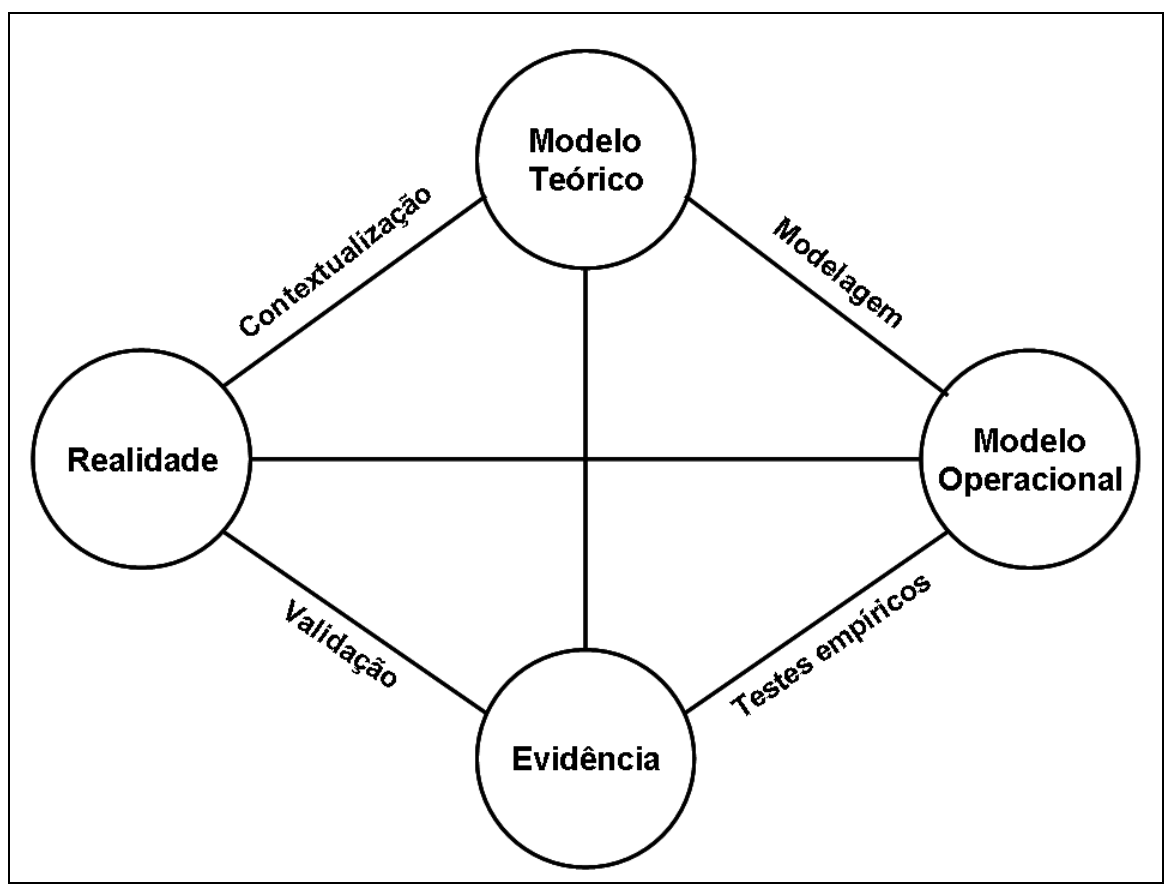

Ilustração 4 - Processo de avaliação de modelos Fonte: Mazzon, 1978, p.22 (adaptado) 
Com base no modelo de avaliação e comparação de modelos propostos por Mazzon (1978), considera-se que, o processo de avaliação de modelos, de modo geral, pode ser analisado em 04 (quatro) etapas: conceitualização, modelagem, teste empírico e evidência, conforme a Ilustração 4.

A realidade na Ilustração 4 representa o objeto da pesquisa, que, em Contabilidade, se refere ao fenômeno contábil de interesse do pesquisador, definindo o que será estudado e, conseqüentemente, qual é o problema de pesquisa e o estabelecimento dos objetivos da investigação científica.

O modelo teórico, como foi apresentado anteriormente, é uma abstração da realidade, enquanto o modelo operacional é uma forma de instrumentalização do modelo teórico, sendo o elemento de ligação entre o modelo teórico e a evidência. Mazzon (1978, p.32) comenta que, "um mesmo tipo de modelo poderá ser aplicável a diferentes situações, problemas ou sistema que são objeto de estudo". Assim, alguns modelos desenvolvidos para auxiliar no estudo de um determinado fenômeno podem ser utilizados em outros propósitos de pesquisa que se revestem de algumas características similares.

Devido à complexidade das relações entre as informações contábeis e os indivíduos, além dos diversos fatores institucionais e organizacionais, procura-se elaborar modelos teóricos e operacionais que contribuam para a compreensão e a predição do comportamento dos agentes econômicos envolvidos com o processo informacional da Contabilidade.

A evidência seria o conjunto de resultados da pesquisa, segundo a metodologia adotada e fruto do emprego do modelo teórico e operacional proposto. A evidência é contraposta à realidade, no qual o pesquisador analisa se as hipóteses levantadas anteriormente são comprovadas ou não e busca explicações para elas.

Com relação às atividades desenvolvidas, a conceitualização refere-se ao processo de fundamentação teórica que fornece suporte para a descrição do modelo teórico e se estabelece na realidade na qual se originou o problema, os objetivos e as hipóteses de pesquisa. Um dos principais elementos do modelo teórico são os seus pressupostos, pois eles definem o espaço em que os resultados do modelo são assegurados. "Usualmente, todos os pressupostos relevantes são explicitamente demonstrados, e eles são o foco das críticas." ${ }^{29}$ (WAGENHOFER, 2004, p. 13).

Os pressupostos objetivam capturar os efeitos principais esperados (efeitos de primeira ordem) das variáveis do modelo, deixando de lado os efeitos menores ou de segunda ordem,

\footnotetext{
${ }^{29}$ Tradução livre de: "Usually, all relevant assumptions are explicitly stated, and they focus of critique."
} 
que se adicionados ao modelo, acrescentam-lhe maior complexidade sem um beneficio superior. Wagenhofer $(2004$, p. 12) considera que existe um trade-off entre o realismo ou generalidade dos pressupostos e a tratabilidade do modelo. As principais críticas sobre os modelos analíticos são ocasionadas pela variedade de ambientes e de pressupostos específicos e que têm efeitos relevantes nos resultados das pesquisas.

O processo de conceitualização, segundo Mazzon (1978, p 41), deve ser avaliado através da "capacidade de formular conceitos, definições, constructos, postulados, problemas, enigmas, paradoxos, etc relevantes para o conhecimento", e, que devido à subjetividade de caracterizar a relevância, torna-se um problema de grau.

No processo de modelagem, o pesquisador irá desenvolver um modelo operacional ou constructo. Constructo compreende a parte de uma construção básica que conecta o desenvolvimento da teoria ao teste (ECHAMBADI, 2006, p.1802). Peter (1981, p. 134) considera que, "um constructo é um termo especificamente definido para um propósito científico especial, geralmente organiza o conhecimento e direciona a pesquisa em um tentativa para descrever e explicar algum aspecto da natureza. ${ }^{30}$.

Em geral, o processo de modelagem especifica através dos modelos operacionais, as relações matemáticas e estatísticas entre a variável dependente (variável de interesse) e a variável independente que são, geralmente, descritas da seguinte forma:

$$
y=f(x)
$$

Normalmente, particiona-se a variável independente em variáveis controláveis $\left(x_{c}\right)$ e variáveis não-controláveis $\left(x_{u}\right)$, tendo-se:

$$
y=f\left(x_{c}, x_{u}\right)
$$

O pesquisador busca desenvolver, à medida do possível, um modelo parcimonioso. Entretanto, uma das principais origens de problemas associados aos modelos empregados é exatamente o processo de simplificação da realidade, na qual se procuram eliminar fatores irrelevantes para o estudo, mas isso possibilita a omissão de fatores relevantes para a devida compreensão do fenômeno.

Os testes empíricos necessitam de teoria e os modelos analíticos fornecem-lhes a teoria. $\mathrm{O}$ modelo operacional (empírico) apresenta aos pesquisadores, quais as variáveis devem ser

\footnotetext{
${ }^{30}$ Tradução livre de: "A construct is a term specifically designed for a special scientific purpose, generally to organize knowledge and direct research in an attempt to describe or explain some aspect of nature".
} 
utilizadas nos estudos e, posteriormente, auxilia na interpretação do resultado (evidências) e sua adequação está relacionada com a capacidade em estabelecer relações significativas dentro de uma representação formal.

Watts e Zimmerman (1986, p.4) alertam que a simples associação entre variáveis, por exemplo, mudanças nos procedimentos contábeis e preços das ações, podem não assegurar causalidade, caso a variação dos preços seja resultado de outros eventos.

Nesse ponto, alerta-se que o pesquisador necessita de uma teoria para explicar as relações entre as variáveis. Ao longo do tempo, a realidade empresarial e as relações entre os agentes econômicos crescem em complexidade, de tal forma que se torna difícil ou até impossível apresentar esse ambiente dentro de uma representação formal.

Segundo Watts e Zimmerman (1986, p. 244), para os testes empíricos de novas teorias, normalmente, deseja-se uma simplicidade no desenvolvimento das suposições. Como apresentado anteriormente, à medida que uma teoria é aceita pelos pesquisadores, observa-se geralmente uma tendência de aprimoramento, o que direciona a pesquisa empírica a evoluir para um detalhamento das premissas inicialmente assumidas e, conseqüentemente, um aperfeiçoamento da teoria e dos modelos.

Muitas evidências apontadas nos estudos podem ser originadas das idiossincrasias de um determinado ambiente, mas servem para prevenir os pesquisadores a não generalizar, rapidamente, hipóteses com argumentos simples, sendo úteis para a compreensão e refinamento da estrutura das pesquisas.

Uma fase crítica da investigação científica é a validação, na qual se questiona se os modelos teóricos e operacionais são adequados ao problema e objetivos da pesquisa. Nesse ponto, deve ser analisado, por exemplo, se as variáveis utilizadas no modelo conseguem captar a realidade. O processo de validação pode conduzir o pesquisador para novas descobertas, através da análise crítica do modelo teórico e operacional proposto.

Evrard et al (1993, p. 284) e Kerling e Lee (2000, p. 666) apontam como os principais tipos de validação: validação de conteúdo, validação preditiva e validação de construto.

A validação de conteúdo fundamenta-se no julgamento do pesquisador e é apoiada pelos seus pares da comunidade científica, tornando-se o objeto de consenso no meio cientifíco. Diante desse fato, Kerlinger e Lee (2000, p. 669) afirmam que a validade de conteúdo é crítica, sendo que cada item deve ser avaliado pela sua relevância assumida para propriedade mensurada (representatividade). O universo do conteúdo deve ser claramente definido e os 'julgadores' (pares no meio científico) devem ser providos das direções específicas do processo de julgamento do pesquisador. 
A validade preditiva refere-se à conexão entre os conceitos (e seus construtos que operacionalizam) e não necessariamente significa previsão, e sim uma predição do comportamento da variável dependente através da(s) variável(is) independente(s), verificando se existe ou não uma relação. A validade empírica exige investigação da relação teórica entre diferentes construtos e a relação empírica entre as medidas dos diferentes construtos.

A validade do construto pretende verificar se os indicadores construídos são uma boa representação do fenômeno estudado. A questão principal da validação é: o construto (instrumento) realmente mensura o que deseja mensurar? Assim, o pesquisador deve estabelecer a extensão na qual as medidas se correlacionam com outras medidas projetadas para mensurar a mesma coisa e se a medida se comporta como esperado (CHURCHILL JR, 1979, p.70).

Validade do construto refere-se à adequação de uma definição operacional de uma variável - a definição de uma variável reflete realmente o verdadeiro significado teórico de uma variável? Muitas variáveis são "construtos" abstratos, [...]. (COZBY, 2003, p.102).

Devido às características subjetivas na mensuração do comportamento discricionário dos resultados contábeis, dificilmente, existirá uma definição operacional perfeita das variáveis utilizadas, assim em algumas pesquisas são empregados vários métodos e abordagens para melhor especificação do modelo.

Segundo Cronbach (1996, p.139), a validade do construto é de difícil descrição porque ela segue em muitas direções, devido à necessidade de várias evidências, enquanto para Cozby (2003, p. 114), a validação de um construto dificilmente será estabelecida em um único estudo, sendo desenvolvida por diversos estudos. Além disso, devido aos resultados das pesquisas realizadas, os pesquisadores observam que medidas utilizadas para as variáveis têm problemas (como, por exemplo, erro de mensuração) e com base nessa constatação desenvolvem-se novas medidas para corrigir tais problemas, levando ao aprimoramento da mensuração das variáveis e do modelo.

Para Evrard et al (1993, p.265), a mensuração estabelece uma correspondência entre o nível teórico e o nível empírico, mas alertam que a medida empírica não é o próprio conceito. Podese considerar que as medidas utilizadas se modificam ao longo do tempo em função do desenvolvimento de melhores medidas, bem como da disponibilização de outras fontes de dados, outras técnicas estatísticas ou mesmo pela revisão da construção do conceito.

Portanto, a medida de uma variável tem vida limitada na pesquisa empírica. Um exemplo desse processo é a proposta de mensuração dos accruals totais pela abordagem na Demonstração do Fluxo de Caixa desenvolvida por Hribar e Collins(2002), e que, segundo os eles, apresentam evidências de melhor especificação para os modelos de identificação de 
accruals anormais, do que a abordagem no Balanço Patrimonial comumente utilizado nas pesquisas correntes. ${ }^{31}$

Além da validação, um instrumento de mensuração (construto) tem ainda que satisfazer aos critérios de confiabilidade e sensibilidade. A medida é confiável quando o fenômeno é avaliado pelo mesmo instrumento por diversas vezes e fornece o mesmo resultado, enquanto a sensibilidade refere-se ao fato de que o instrumento de mensuração deve registrar poucas variações do fenômeno.

A medida empírica utilizada da variável pode ser representada da seguinte forma (CHURCHILL JR., 1979, p.65):

$$
X_{o}=X_{t}+X_{s}+X_{r}
$$

em que:

$X_{o} \quad=$ medida observada (empírica);

$X_{t} \quad=$ verdadeiro valor ou medida ideal, ou seja, aquele que representa realmente o fenômeno;

$X_{s}=$ erro sistemático ou viés, representa o erro originado da falha de mensuração do instrumento utilizado;

$X_{r} \quad=$ erro aleatório, representa $\mathrm{o}$ erro originado da aleatoriedade de certas circunstâncias.

Churchill Jr. (1979, p.65) e Evrard et al (1993, p. 278) consideram que o problema da confiabilidade se refere ao erro aleatório. Uma medida (construto) é confiável se a sua utilização repetidamente gera os mesmos resultados, assim para ser perfeitamente confiável, erro aleatório deve ser igual a zero $\left(X_{r}=0\right)$. Por outro lado, o problema da validade depende simultaneamente dos dois erros, portanto, considera-se que confiabilidade é uma condição necessária mas não suficiente para validade.

Para Evrard et al (1993, p. 284) e Kerlinger e Lee (2000, p. 670), a validade do construto é um dos mais importantes avanços da teoria e prática de mensuração, pois relaciona as noções psicométricas e noções teóricas à prática. Peter (1981, p.133) afirma que as teorias não podem ser desenvolvidas a menos que exista um alto nível de correspondência entre os construtos abstratos e os procedimentos utilizados para sua operacionalização, sendo que a validade do construto permite relacionar o nível de correspondência entre os construtos e suas medidas,

\footnotetext{
${ }^{31}$ A apresentação e discussão dessas duas abordagens de estimação dos accruals totais são realizadas na seção 3.2 deste trabalho.
} 
portanto, a validade do construto é uma condição necessária para o desenvolvimento e testes da teoria.

Segundo Cronbach (1996, p. 170) e Evrard et al (1993, p. 285), a validade do construto consiste em verificar se os indicadores supostamente mensuram a mesma coisa (validade convergente). Convergência significa que evidências de diferentes fontes reunidas de todas as maneiras diferentes indicam o mesmo ou significado similar do construto (KERLINGER; LEE, 2000, p. 671-672).

Para Churchill Jr. (1979, p.70), a evidência da validade convergente da medida é fornecida pela alta correlação com outros métodos desenhados para medir o mesmo construto. Porém, a medida também deve possuir validade discriminante, isto é, a medida é realmente nova e não simplesmente um reflexo de alguma outra variável. 

GERENCIAMENTO DOS RESULTADOS CONTÁBEIS

Os estudos sobre manipulação das informações contábeis focam, principalmente, a investigação dos fatores determinantes nas escolhas contábeis. Essa linha de pesquisa basicamente se iniciou na década de 1960, evoluindo nos anos subseqüentes e, a partir dos meados da década 1980, têm se concentrado, primariamente, na análise dos accruals (BENEISH, 2001, p.3).

Muitos desses estudos sobre gerenciamento dos accruals, basicamente, decompõem as acumulações totais em discricionárias e não-discricionárias. Apesar de nenhum dos dois componentes serem observados diretamente, existem diversas proxies e modelos sugeridos. Para tanto, alguns modelos operacionais foram desenvolvidos para auxiliar as pesquisas empíricas sobre gerenciamento de resultados através dos accruals ou das atividades operacionais.

Os modelos propostos consideram que o accrual discricionário é uma proxy do gerenciamento de resultados contábeis (HEALY, 1985; McNICHOLS; WILSON, 1988; JONES, 1991, DECHOW et al, 1995; KANG; SIVARAMAKRISHNAN, 1995). Como já foi apresentado na seção 2.4 deste trabalho, existem outras abordagens alternativas para os accruals agregados que seriam a análise de accruals específicos e a análise da distribuição de freqüências (análise de histograma).

Este trabalho analisou os modelos baseados em accruals agregados, devido a maiores possibilidades de inferência nos diversos ambientes econômicos e nos fatores institucionais e organizacionais.

Teoh et al (1998) consideram que o nível de gerenciamento de resultados pode ser analisado através dos accruals discricionários mensurados pelos modelos existentes na literatura. Porém, segundo Roychowdhury (2006), os accruals discricionários podem ser afetados pela manipulação das atividades operacionais. Assim, os modelos propostos para detecção de gerenciamento de resultados (baseados exclusivamente em accruals) não segregam, adequadamente, o componente anormal dos resultados contábeis causados pela manipulação dos accruals e pela manipulação das atividades reais.

O foco deste trabalho é analisar a estimação dos accruals discricionários, utilizados como proxy para o gerenciamento de resultados contábeis. Apesar de existir outras formas de 
manipulação das informações contábeis, são analisados aqui somente àquelas que afetam aos resultados contábeis, especificamente, os modelos que decompõem os accruals totais em gerenciados e não-gerenciados.

Um ponto importante a ser destacado nesse momento é que, em grande parte dos trabalhos anteriores, têm sido extraídas inferências sobre hipóteses conjuntas, pois, à medida que se analisam os incentivos para o gerenciamento de resultados, ao mesmo tempo que se verifica a validade empírica dos modelos utilizados para identificar os accruals discricionários e nãodiscricionários.

A preocupação deste trabalho é com a possibilidade de erro de mensuração nos trabalhos empíricos nessa linha de pesquisa, pois além da inserção do ruído estatístico, leva o pesquisador à busca de explicações alternativas sobre as hipóteses levantadas.

Esse capítulo discute, no primeiro momento, a formação dos resultados contábeis e seus componentes (fluxo de caixa e accruals) e, em seguida, são analisados os modelos propostos para estimação dos accruals totais. Isso se faz necessário, para que se possa verificar a origem e natureza dos accruals e, em seguida, avaliar a especificação dos modelos operacionais para a identificação do componente normal e anormal dos accruals. Por último, busca-se um realinhamento do modelo para mensuração dos accruals não-discricionários e discricionários, com base no referencial teórico sobre o tema, observando, em especial, as considerações metodológicas e evidências empíricas apresentadas nos diversos estudos anteriores.

\subsection{Resultados contábeis, fluxo de caixa e accruals}

Segundo Graham et al (2005), os executivos financeiros acreditam que o resultado contábil é a principal métrica utilizada para avaliação do desempenho pelos agentes econômicos externos à empresa. Isso mostra a importância dos números contábeis no meio empresarial, a relevância em se estudarem os componentes que formam o resultado contábil (fluxo de caixa e accruals) e como cada um desses elementos se comporta em face dos diversos fatores institucionais e organizacionais.

O regime de competência (accruals basis) distingue o reconhecimento dos custos e benefícios associados com as atividades econômicas e os pagamentos e recebimentos de caixa, diferentemente, do regime de caixa (cash basis). Com base nesse conceito, os efeitos das transações e eventos econômicos são reconhecidos com base em estimativas futuras de 
recebimentos e pagamentos de caixa, afetando o resultado líquido da empresa (PALEPU et al, 2004, p.1-4).

Devido à demanda dos usuários da Contabilidade por informações periódicas mais próximas do desempenho econômico da empresa, deve ser efetuado o reconhecimento no resultado das receitas e despesas incorridas no período, independentemente, das suas realizações financeiras.

O modelo contábil baseado no regime de competência incorpora a intuição de que o momento dos efeitos econômicos das transações e eventos, freqüentemente, difere do momento da realização dos fluxos de caixa relacionados, no qual o beneficio dos accruals é exatamente efetuar o ajuste entre o fluxo de caixa e o regime de competência.

Demski (2004, p.519) considera que o regime de competência é uma demonstração formal da de estoques e fluxos antecipados. Por exemplo, vários ativos e passivos (não-caixa) evidenciados no Balanço Patrimonial representam estoques de benefícios e pagamentos antecipados, ao passo que os componentes não-caixa do resultado contábil são os fluxos de vários accruals e que representam fluxos de benefícios antecipados e consumo de recursos. Ou seja, o Balanço Patrimonial é uma demonstração que, além de caixa e equivalentes, evidencia os estoques de benefícios e sacrifícios antecipados ou postergados, enquanto a Demonstração de Resultados é uma demonstração dos fluxos de benefícios auferidos e recursos consumidos em um determinado período.

Geralmente, os accruals refletem as expectativas dos administradores sobre os fluxos de caixa futuro e são baseados sobre um sistema de informações, potencialmente, mais abrangentes do que fluxos de caixa passados e correntes. ${ }^{32}$ (BEAVER, 1998, p.6).

Assim, o regime de competência fornece melhores informações do desempenho econômico da empresa do que o fluxo de caixa, pois minimiza os problemas de velocidade e sincronia inerentes à mensuração pelo fluxo de caixa em curtos intervalos de tempo (DECHOW, 1994; SUBRAMANYAM, 1996).

O fluxo de caixa é considerado como montante de entradas e saídas de recursos financeiros que uma empresa tem dentro de um determinado período, o que o diferencia do regime de competência, pois esse último observa prioritariamente o momento dos efeitos econômicos das transações e eventos..

O accrual surge da diferença temporal entre os efeitos econômicos das transações e eventos e os fluxos de caixa correspondentes não realizados ou realizados anteriormente. Se uma receita for reconhecida em um determinado período e o seu recebimento ocorrer ao longo do mesmo

\footnotetext{
${ }^{32}$ Tradução livre de: "Generally, the accruals reflect management's expectations about future cash flows and are based on an information system potentially more comprehensive than past and current cash flows."
} 
período, não existe diferença entre o fluxo de caixa do período e o resultado contábil apurado pelo regime de competência, logo não existe accrual. Entretanto, se a receita fosse recebida somente nos períodos futuros, então essa diferença seria o componente do resultado contábil denominado accrual. $^{33}$

O papel dos accruals é ajustar o resultado da empresa no período, porque a mensuração exclusivamente pelo caixa não reconhece o efeito econômico total da transação ou evento (DECHOW; DICHEV, 2002, p.36).

Diversos trabalhos documentam que o processo de accruals faz com que os resultados contábeis tenham uma melhor medida para o desempenho econômico do que se fossem mensuradas pelos fluxos de caixa (DECHOW, 1994; DECHOW et al, 1998; LIU et al, 2002). Considera-se que o resultado contábil da empresa, em um determinado período $t$, é derivado dos fluxos de caixa no período $t$ e do processo de mensuração dos accruals no período $t$, que pode ser representado da seguinte forma:

$$
E_{t}=C F_{t}+T A_{t} \quad(\text { Equação } 1.01)^{34}
$$

em que:

$E_{t} \quad=$ resultado contábil da empresa no período $t$;

$C F_{t} \quad=$ fluxo líquido de caixa da empresa no período $t$;

$T A_{t} \quad=$ accruals totais da empresa no período $t$.

Os accruals são baseados em pressupostos e estimativas da administração, com relação às expectativas futuras de recebimentos e pagamentos dos fenômenos econômicos (transações e eventos) ocorridos no presente período. Segundo Beaver (1998, p.83-84), os “accruals são freqüentes, estão presentes em quase todas as firmas de certa forma e são uma das características centrais do sistema de relatórios financeiros. ${ }^{, 35}$

Cabe ressaltar que, a representação do resultado contábil, conforme a Equação 1.01, tem como premissa que todas as variações patrimoniais transitam pelo resultado do período. Essa representação matemática, por exemplo, não é válida quando as empresas realizam reavaliações de seus ativos ou possuem subvenções para investimentos, o que é permitido, atualmente, pelas normas contábeis brasileiras.

\footnotetext{
${ }^{33}$ Para melhor entendimento da dinâmica entre o regime de competência e fluxo de caixa, sugere-se ao leitor consultar Eliseu Martins (1999).

${ }^{34}$ A notação matemática dos modelos neste estudo segue, em alguns casos, a forma descrita segundo a língua inglesa, pelo fato de que muitas delas são extensamente utilizadas em pesquisas anteriores, inclusive no Brasil.

${ }^{35}$ Tradução livre de: "Accruals are widespread, are present in almost every firm to some extent, and are a key feature of the financial system."
} 
Sunder (1997, p.67) considera que o lucro total ao longo da vida da empresa é independente das escolhas contábeis utilizadas pela administração para reportar os números contábeis, desde que não alterem o fluxo de caixa da empresa e observado o conceito de clear surplus ${ }^{36}$. Esse conceito é denominado de Lei da Conservação dos Resultados.

Devido à natureza dos accruals, espera-se que elas sejam revertidas nos períodos futuros com sinal contrário. Para melhor compreensão, observe o seguinte exemplo: Um venda de $\$ 1.000$ efetuada no período $t$, e que seu recebimento somente ocorre no período $t+1$ (Tabela 3 ).

Tabela 3 - Diferença temporal entre o resultado contábil e o fluxo de caixa e a Lei da Conservação dos Resultados

\begin{tabular}{|l|c|c|c|}
\hline & Período $\boldsymbol{t}$ & Período $\boldsymbol{t}+\boldsymbol{1}$ & Total \\
\hline Demonstração do Resultado & & & \\
\hline Receitas ${ }^{77}$ & 1.000 & & 1.000 \\
\hline Lucro líquido $\left(\mathrm{E}_{\mathrm{t}}\right)$ & 1.000 & & 1.000 \\
\hline & & & \\
\hline Demonstração do Fluxo de Caixa & & & 1.000 \\
\hline Recebimentos & 0 & 1.000 & \\
\hline Pagamentos & & & 1.000 \\
\hline Fluxo Líquido $\left(\mathrm{FC}_{\mathrm{t}}\right)$ & & 1.000 & $\mathbf{0}$ \\
\hline & & & $\mathbf{( 1 . 0 0 0 )}$ \\
\hline Accruals $\left(\mathrm{TA}_{\mathrm{t}}\right)$ & $\mathbf{1 . 0 0 0}$ & & \\
\hline
\end{tabular}

Como pode ser observado, existe um processo natural de reversão dos accruals, ou seja, quando um montante de accruals é reconhecido, positivamente, em um determinado período, espera-se que nos exercícios posteriores ocorra um mesmo montante, porém negativo.

Para fins de simplificação teórica do modelo de accruals, o trabalho foca nos accruals do capital circulante, pois a priori:

a) os accruals devem ser revertidos no período subseqüente, o que facilita a especificação de modelos mais parcimoniosos para o estudo e estimação dos componentes nãodiscricionários e discricionários, e

b) a prática oportunística está mais voltada aos incentivos de curto prazo (GRAHAM et al, 2005).

Dechow e Dichev (2002) apresentam o fluxo de caixa de uma empresa no período $t$ da seguinte forma:

$$
C F_{t}=C F_{t}^{t-1}+C F_{t}^{t}+C F_{t}^{t+1} \quad(\text { Equação 1.02) })^{38}
$$

\footnotetext{
${ }^{36} \mathrm{O}$ conceito de clear surplus estabelece que todas as mutações ocorridas no patrimônio líquido da firma transitam pelo resultado contábil, exceto as variações originadas de transações com os próprios acionistas.

${ }^{37}$ Para fins de simplificação do exemplo, desconsiderem-se as despesas associadas.
} 
em que:
$C F_{t} \quad=$ fluxo líquido de caixa da empresa no período $t$;
$C F_{t}^{t-1} \quad=$ recebimentos e pagamentos de caixa no período $t$ referentes aos valores reconhecidos (accrued) no resultado contábil do período $t-1$;
$C F_{t}^{t} \quad=$ recebimentos e pagamentos de caixa no período $t$ referentes aos valores reconhecidos (accrued) no resultado contábil do próprio período $t$;
$\mathrm{CF}_{\mathrm{t}}^{\mathrm{t}+1}=$ recebimentos e pagamentos de caixa no período $t$ referentes aos valores que serão reconhecidos (accrued) no resultado contábil do período $t+1$.

O modelo teórico de mensuração dos resultados contábeis no período $t$ através dos fluxos de caixa pode ser representado da seguinte forma ${ }^{39}$ :

$$
E_{t}=C F_{t-1}^{t}+C F_{t}^{t}+C F_{t+1}^{t}+\varepsilon_{t+1}^{t}-\varepsilon_{t}^{t-1} \quad \text { (Equação 1.03) }
$$

em que:

$\begin{array}{ll}E_{t} & =\text { resultado contábil da empresa no período } t ; \\ C F_{t-1}^{t} & =\text { recebimentos e pagamentos de caixa no período } t-1 \text {, mas reconhecidos no }\end{array}$ resultado contábil em $t$ (reversão dos accruals anteriores);

$C F_{t}^{t} \quad=$ recebimentos e pagamentos de caixa no período $t$ referentes às valores reconhecidos (accrued) no resultado do próprio período $t$;

$C F^{t+1} \quad=$ recebimentos e pagamentos de caixa no período $t+1$, mas reconhecidos no resultado contábil em $t$ (novos accruals);

$\varepsilon_{t+1}^{t}=\quad$ erro de estimativa nos accruals no período $t$, referentes aos fluxos de caixa do período $t+1$;

$\varepsilon_{t}^{t-1}=\quad$ erro de estimativa nos accruals no período $\mathrm{t}-1$, referentes aos fluxos de caixa do período $t$.

No caso em que os accruals estimados reconhecidos nos resultados do período $t-1$ não sejam realizados (monetariamente) no momento $t$, eles devem ser corrigidos no período $t$, através do próprio processo de accruals, que ajustaram os resultados contábeis aos efeitos dos accruals

\footnotetext{
${ }^{38}$ As fórmulas nessa seção, em particular, seguem o seguinte critério de notação matemática: o indicador subscrito $\left(x_{t}\right)$ referese ao período no qual ocorre o efeito no caixa (recebimentos e pagamentos), enquanto o indicador sobrescrito $\left(x^{t}\right)$ refere-se ao período no qual ocorre o reconhecimento no resultado contábil.

${ }^{39}$ A derivação completa do modelo está descrita mais detalhadamente em Dechow e Dichev (2002).
} 
não realizados devido ao erro de mensuração das expectativas e estimativas, e conseqüentemente, afetam os lucros naquele período.

Entretanto, os fluxos de caixa já recebidos no período $t-1$ e que serão reconhecidos no resultado contábil no período $t$, tem pouca ou nenhuma probabilidade de ocorrerem em erro de mensuração (pelo menos não intencional), assim esse elemento foi eliminado do modelo proposto (Equação 1.03).

Os erros de estimativas nos accruals ( $\varepsilon$ ) e suas subseqüentes correções são interferências que reduzem os benefícios da utilização dos accruals. Alguns desses erros de estimação são ocasionados pelas características idiossincráticas das firmas e pela complexidade das transações e eventos econômicos. A magnitude dos erros, intencionais ou não, de estimativa prejudicam a qualidade dos accruals dos resultados e, conseqüentemente, a utilidade da informação contábil para os usuários. Assim, para Thomas e Zhang (2000) torna-se relevante analisar e compreender o comportamento dos accruals, em particular, identificando a parcela não realizada devido ao simples erro de estimativa (não intencional) e a parcela originada do comportamento oportunístico.

Rearranjando as Equações 1.01 a 1.03, pode-se observar a parcela dos accruals nos resultados correntes (DECHOW; DICHEV, 2002, p.40):

$$
\begin{gathered}
E_{t}=C F_{t}+T A_{t} \\
T A_{t}=E_{t}-C F_{t} \\
T A_{t}=\left(C F_{t-1}^{t}+C F_{t}^{t}+C F_{t+1}^{t}+\varepsilon_{t+1}^{t}-\varepsilon_{t}^{t-1}\right)-\left(C F_{t}^{t-1}+C F_{t}^{t}+C F_{t}^{t+1}\right) \\
T A_{t}=C F_{t-1}^{t}-\left(C F_{t}^{t-1}+C F_{t}^{t+1}\right)+C F_{t+1}^{t}+\varepsilon_{t+1}^{t}-\varepsilon_{t}^{t-1} \quad \text { (Equação 1.04) }
\end{gathered}
$$

em que:

$T A_{t} \quad=$ accruals totais da empresa no período $t$;

$C F_{t-1}^{t} \quad=$ recebimentos e pagamentos de caixa no período $t-1$, mas reconhecidos no resultado contábil em $t$ (reversão dos accruals anteriores);

$C F_{t}^{t-1} \quad=$ recebimentos e pagamentos de caixa no período $t$ referentes aos valores reconhecidos (accrued) no resultado do período $t-1$;

$C F_{t}^{t+1} \quad=$ recebimentos e pagamentos de caixa diferidos para o período $t$ referentes aos valores reconhecidos (accrued) no resultado do período $t+1$;

$C F_{t+1}^{t} \quad=$ recebimentos e pagamentos de caixa no período $t+1$, mas reconhecidos no resultado contábil em $t$; 
$\varepsilon_{t+1}^{t}=\quad$ erro de estimativa nos accruals no período $t$, referentes aos fluxos de caixa do período $t+1$;

$\varepsilon_{t}^{t-1}=\quad$ erro de estimativa nos accruals no período $\mathrm{t}-1$, referentes aos fluxos de caixa do período $t$.

Com base nas transformações algébricas da Equação 1.01 à Equação 1.04, observa-se que somente as transações e eventos que tenham recebimentos e/ou pagamentos de caixa no período $t$ e reconhecidas no próprio período $t$, não têm efeitos nos accruals do período $t$. Enquanto os itens dos fluxos de caixa não reconhecidos no resultado do próprio período $t$, já foram reconhecidos em períodos anteriores ou serão nos resultados futuros.

Assim, através do modelo analítico descrito por Dechow e Dichev (2002), demonstra-se a tese defendida por Eliseu Martins (1999, p.1) de que "o Balanço e Demonstração do Resultado, se elaborados a luz do custo histórico puro e na ausência de inflação, é a distribuição lógica e racional ao longo do tempo do Fluxo de Caixa da empresa." O mesmo autor ainda completa afirmando que "o lucro obrigatoriamente transita pelo caixa da empresa.” (ibid, p.1).

Conforme Equação 1.04, as variações dos accruals em um determinado período podem ser consideradas como parcelas dos fluxos de caixa passado, presente e futuro, assim, pode-se descrever o modelo operacional para mensuração da qualidade dos accruals do capital de giro da seguinte forma:

$$
\Delta W T A_{t}=\alpha_{0}+\beta_{1}\left(C F_{t-1}\right)+\beta_{2}\left(C F_{t}\right)+\beta_{3}\left(C F_{t+1}\right)+\varepsilon_{t} \quad \text { (Equação 1.05) }
$$

em que:

$\Delta W T A_{i t}=$ variação dos accruals do capital de giro da empresa $i$ do período $t-1$ para o período $t$, ponderada pelos ativos totais no final do período $t-1$;

$C F_{t-1} \quad=$ fluxos de caixa no período $t-1$, ponderados pelos ativos totais no final do período $t-2$;

$C F_{t} \quad=$ fluxos de caixa no período $t$, ponderados pelos ativos totais no final do período $t-1$;

$C F_{t+1} \quad=$ fluxos de caixa no período $t+1$, ponderados pelos ativos totais no final do período $t$;

$\varepsilon_{t}=\quad$ erro de estimativa nos accruals no período $t$;

$\alpha, \beta_{1}, \beta_{2} e \beta_{3}=$ coeficientes estimados da regressão pela Equação 1.05. 
Segundo Dechow e Dichev (2002), os resíduos da regressão são os accruals que não estão vinculados com a realização do fluxo de caixa e o desvio-padrão desses resíduos é uma medida de qualidade dos accruals. Considera-se que, quanto maior o desvio-padrão, menor a qualidade dos accruals.

Com base no modelo apresentado acima, Dechow e Dichev (2002, p.39-40) afirmam que:

a) Os accruals são ajustes temporários que diferem ou antecipam o reconhecimento de fluxos de caixa realizado mais um termo do erro de estimativa;

b) Os accruals são negativamente relacionados aos fluxos de caixa corrente e positivamente relacionados aos fluxos de caixa passados e futuros;

c) O termo de erro da estimativa captura a extensão em que os accruals se ajustam dentro dos fluxos de caixa realizados.

Complementarmente, podem ser esperadas as seguintes relações estatísticas entre resultados, fluxos de caixa e accruals (ibid, p.39-40):

a) Correlação positiva entre o resultado corrente e o fluxo de caixa corrente: $\operatorname{Corr}\left(E_{t}, C F_{t}\right)=+$

b) Correlação positiva entre o resultado corrente e os accruals correntes: $\operatorname{Corr}\left(E_{t}, A c_{t}\right)=+$

c) Correlação negativa entre o fluxo de caixa corrente e os accruals correntes: $\operatorname{Corr}\left(F C_{t}, T A_{t}\right)=-$

d) Correlação positiva entre o resultado corrente e os fluxos de caixa futuros: $\operatorname{Corr}\left(E_{t}, C F_{t+1}\right)=+$

e) Correlação positiva entre os accruals correntes e os fluxos de caixa futuros: $\operatorname{Corr}\left(T A_{t}, C F_{t+1}\right)=+$

f) Correlação positiva entre o resultado corrente e os fluxos de caixa passados: $\operatorname{Corr}\left(E_{t}, C F_{t-1}\right)=+$

g) Correlação positiva entre os accruals correntes e os fluxos de caixa passados: $\operatorname{Corr}\left(T A_{t}, C F_{t-1}\right)=+$

As relações descritas nos itens $a$ a $c$ foram estatisticamente confirmadas por Dechow (1994), Dechow et al (1998) e Dechow e Dichev (2002). As relações descritas nos itens $d$ e $e$ sugerem que os resultados e os accruals têm a capacidade preditiva de antecipar o fluxo de caixa futuro, sendo confirmadas por Finger (1994), Subramanyam (1996), Barth et al (2001) e Dechow e Dichev (2002). As relações entre resultado e accruals correntes com os fluxos de caixa passados foram testadas e comprovadas por Dechow e Dichev (2002). 
Dechow (1994) e Subramanyam (1996) evidenciam que as variações nos accruals em determinado período representam acumulações não-discricionários que são efetuadas com o intuito de eliminar problemas de temporalidade no fluxo de caixa operacional, causando uma correlação negativa entre a variação do fluxo de caixa e os accruals. Então, um modelo bem especificado de accruals não-discricionários deve controlar esse efeito, que é originado pelo regime de competência. Entretanto, Dechow et al (1995, p.209-210) demonstram que os modelos existentes não controlam completamente essa correlação negativa.

McNichols (2002, p.63) alerta que o modelo apresentado por Dechow e Dichev (2002), assume o pressuposto de que os accruals são de curto prazo, o que limita a aplicabilidade desse modelo em estudos que analisam aspectos de longo prazo.

Cabe ressaltar, ainda, que Beaver (1998, p.2-3) considera o processo de accruals ambíguo e não bem definido, pois para muitos eventos que afetam os números contábeis pode existir uma variedade de métodos alternativos de reconhecimento de receitas e despesas.

\subsection{Processo de estimação dos accruals totais}

Os accruals operacionais totais (a partir desse ponto do trabalho representado por $T A$ ) podem ser apurados através das contas do Balanço Patrimonial ou diretamente da Demonstração do Resultado e do Fluxo de Caixa.

A abordagem de estimação mais utilizada na literatura é a baseada nas contas do Balanço Patrimonial (HEALY, 1985; DeANGELO, 1986; JONES, 1991; DECHOW et al, 1995; KANG; SIVARAMAKRISHNAN, 1995; BURGSTAHLER; DICHEV, 1997; TEOH et al, 1998; HEALY; WAHLEN, 1999; MARTINEZ, 2001; ZENDERSKY, 2005; PAE, 2005; ALMEIDA, 2006).

A estimação dos accruals, através do Balanço Patrimonial, está fundamentada no pressuposto de que as mudanças nas contas do capital circulante estão articuladas com os componentes dos accruals de receitas e despesas na Demonstração de Resultado. Essa abordagem é a mais utilizada nos estudos pelo fato de que os dados necessários para o seu desenvolvimento encontram-se disponíveis a mais tempo do que os exigidos para utilizar a abordagem da Demonstração do Fluxo de Caixa. 
Pela abordagem do Balanço Patrimonial, os accruals totais são calculados da seguinte forma:

$$
T A_{t}=\frac{\left(\Delta A C_{t}-\Delta D i s p_{t}\right)-\left(\Delta P C_{t}-\Delta D i v_{t}\right)-D e p r_{t}}{A_{t-1}} \quad \text { (Equação 2.01) }
$$

em que:

$T A_{t} \quad=$ accruals (operacionais) totais da empresa no período $t$;

$\Delta A C_{t} \quad=$ variação do ativo corrente (circulante) da empresa no final do período $t$ - 1 para o final do período $t$;

$\Delta$ Disp $_{t} \quad=$ variação das disponibilidades da empresa no final do período $t-1$ para o final do período $t$

$\Delta P C_{t}=$ variação do passivo corrente (circulante) da empresa no final do período $t-1$ para o final do período $t$;

$\Delta D i v_{t} \quad=$ variação dos financiamentos e empréstimos de curto prazo da empresa no final do período $t-1$ para o final do período $t$;

Depr $_{t}=$ montante das despesas com depreciação e amortização da empresa durante o período $t$

$A_{t-1} \quad=$ ativos totais da empresa no final do período $t-1$.

Por essa medida, os accruals são calculados pela variação da diferença entre ativo corrente operacional e o passivo corrente operacional, deduzidas as despesas de depreciação e amortização no período, estando baseada na suposta articulação dos componentes dos accruals (receitas e despesas) na Demonstração de Resultado com as contas do capital circulante líquido no Balanço Patrimonial.

Entretanto, esse pressuposto assumido fica fragilizado quando ocorrem eventos e transações não operacionais como reclassificações, aquisição e venda de negócios, mudanças de critérios contábeis, entre outros (HIBRAR; COLLINS, 2002, p.106). Portanto, os accruals sob a abordagem do Balanço Patrimonial utilizados em diversos estudos podem contaminar as evidências empíricas devido ao erro de mensuração das estimativas das acumulações.

Hribar e Collins (2002) evidenciam que erro induzido pela estimação baseada na abordagem do Balanço Patrimonial contamina a mensuração dos accruals discricionários e, conseqüentemente, pode conduzir o pesquisador a inferências equivocas em seus estudos. Uma outra abordagem para o cálculo dos accruals totais seria através da coleta direta das variáveis necessárias nas Demonstrações Contábeis, especificamente, Demonstração de Resultados e Demonstração dos Fluxos de Caixa. Hribar e Collins (2002) apresentam duas 
alternativas de mensuração dos accruals totais nessa abordagem. A primeira alternativa é descrita da seguinte forma (HRIBAR; COLLINS, 2002, p.109):

$$
T A_{t}^{c f}=\frac{E B X I_{t}-C F O_{t}}{A_{t-1}} \quad(\text { Equação 2.02) }
$$

em que:

$T A_{t}^{c f} \quad=$ accruals (operacionais) totais mensurados diretamente através dos itens da Demonstração de Resultados e Demonstração dos Fluxos de Caixa da empresa no período $t$;

$E B X I_{t} \quad=$ resultados antes itens extraordinários e operações descontinuadas da empresa no período $t$;

$\mathrm{CFO}_{t} \quad=$ fluxo de caixa operacional evidenciado diretamente na Demonstração de Fluxo de Caixa da empresa no período t;:

$A_{t-1} \quad=$ ativos totais da empresa no final do período $t-1$.

A segunda alternativa é a mensuração através dos itens que compõem o ativo e passivo corrente operacional, sendo que, para Hribar e Collins (2002, p.109), é a medida mais diretamente comparável aos valores apurados na abordagem em Balanço Patrimonial. Essa medida é calculada diretamente pelos itens constantes na Demonstração dos Fluxos de Caixa no método indireto, conforme a Equação abaixo:

$$
T A_{t}^{c f}=\frac{\Delta C R_{t}^{c f}+\Delta I N V_{t}^{c f}-\Delta C P_{t}^{c f}-\Delta T X_{t}^{c f}-D E P_{t}^{c f}+\Delta O A P_{t}^{c f}}{A_{t-1}}
$$

em que:

$T A_{t}^{c f} \quad=$ accruals totais mensurados através da Demonstração de Fluxo de Caixa (método indireto) no período $t$;

$\Delta C R_{t}^{c f} \quad=$ variação das contas a receber de clientes no final do período $t-1$ para o final do período $t$;

$\Delta I N V_{t}^{c f} \quad=$ variação das contas de estoques no final do período $t-1$ para o final do período $t$;

$\Delta C P_{t}^{c f}=$ variação das contas a pagar a fornecedores no final do período $t-1$ para o final do período $t$;

$\Delta T X_{t}^{c f}=$ variação das impostos e contribuições tributárias no final do período $t-1$ para o final do período $t$;

$D E P_{t}^{c f}=$ despesa com depreciação no período $t$; 
$\triangle O A P_{t}^{c f}=$ variação líquida das outras contas do ativo e passivo corrente da empresa no final do período $t-1$ para o final do período $t$;

$A_{t-1} \quad=$ ativos totais no final do período $t-1$.

Observa-se que todas as variáveis explicativas na segunda alternativa são extraídas da Demonstração de Fluxo de Caixa divulgada pela empresa e não são afetadas pelas operações não-operacionais. Com relação à variável $D E P^{c f}$, o trabalho de Hribar e Collins (2002) somente refere-se à despesa com depreciação, não tecendo nenhum comentário sobre as despesas com amortização, o que em algumas pesquisas podem afetar significativamente as evidências apresentadas.

A questão é que os accruals, bem como muitas outras variáveis utilizadas nas pesquisas empíricas, não podem ser coletados de forma a representar verdadeiramente o seu comportamento econômico, portanto procura-se uma variável proxy que, de certa forma, esteja associada à variável não-observada. Porém esse tratamento pode levar o pesquisador à utilização de uma mensuração imprecisa, fazendo com que o modelo empregado contenha um erro de medida.

Wooldridge (2002, p.292) explica que "o pressuposto comum é que o erro de medida em yé estatisticamente independente de cada variável explicativa. Se isso for verdadeiro, então os estimadores MQO são não-enviesados e consistentes." ${ }^{40}$ Portanto, o erro de medida na variável dependente não correlacionado com as variáveis preditoras não afeta a qualidade dos estimadores do método dos Mínimos Quadrados Ordinários (MQO).

Hribar e Collins (2002, p.133) evidenciam que o modelo Jones baseado nos accruals calculados diretamente pela Demonstração de Fluxo de Caixa possui menor magnitude de erro de mensuração dos accruals discricionários do que pela abordagem no Balanço Patrimonial. Tal evidência sugere que as pesquisas empíricas pautadas na mensuração através do Balanço Patrimonial podem apresentar inferências errôneas sobre as hipóteses de gerenciamento de resultados das empresas.

\footnotetext{
${ }^{40}$ Tradução livre de: The usual assumption is that the measurement error in y is statistically independent of each explanatory variable. If this is true, then the OLS estimators from are unbiased and consistent.
} 


\subsection{Modelo para deteç̧ão de gerenciamento de resultados através dos accruals}

A detecção do gerencimento de resultados, através dos accruals, é realizada em dois passos: (1) estimar os accruals discricionários, proxy para gerenciamento de resultados e (2) verificar se existe uma relação causal significativamente relevante (normalmente por meio de regressão) entre os accruals discricionários estimados e os incentivos (ou fatores institucionais) que supostamente afetam o comportamento dos números contábeis.

Portanto, o processo inicia-se pela mensuração das acumulações totais (total accruals), sendo que, em seguida, são utilizados nos modelos operacionais que os decompõem em discricionários (gerenciados) e não-discricionários (não-gerenciados).

Segundo Kang e Sivaramakrishnan (1995, p.353):

Nos estudos empíricos sobre gerenciamento de resultados (EM), a origem principal é a estimação do componente gerenciado (accruals discricionários), enquanto os agentes externos observam somente a soma dos números contábeis gerenciados ou não-gerenciados (accruals nãodiscricionários). ${ }^{41}$

Nas pesquisas sobre gerenciamento de resultados, os modelos necessitam identificar adequadamente os accruals discricionários (discretionary accruals), que supostamente seriam artificiais e teriam como único objetivo somente manipular o resultado contábil ${ }^{42}$, enquanto as acumulações não-discricionárias (nondiscretionary accruals) são inerentes às atividades da empresa. Exatamente, nessa decomposição dos accruals reside a principal dificuldade dos métodos para detecção de gerenciamento de resultados através dos accruals, pois, devido à complexidade das relações entre os accruals, resultados contábeis e fluxos de caixa e os fatores condicionantes do comportamento oportunístico dos administradores e as características institucionais e organizacionais do ambiente analisado.

McNichols e Wilson (1988) descrevem uma estrutura comum que serve de base para detecção de gerenciamento de resultados através dos accruals. As acumulações totais TA* (total accruals) são decompostas em acumulações discricionárias $D A^{*}$ (discretionary accruals) e acumulações não-discricionárias $N D A^{*}$ (nondiscretionary accruals), tal como:

$$
T A_{t}^{*}=N D A_{t}^{*}+D A_{t}^{*} \quad(\text { Equação } 3.01)
$$

em que:

$T A_{t}{ }^{*} \quad=$ accruals totais reais da empresa no período $t$

\footnotetext{
${ }^{41}$ Tradução livre de: "In empirical studies of earnings management (EM), a central issue is the estimation of the managed component (discretionary accruals) when outsiders observe only the sum of the managed and unmanaged (nondiscritionary) accounting numbers. "

${ }^{42}$ Considerando a visão oportunística.
} 
$N D A_{t}{ }^{*} \quad=$ accruals não-discricionários reais da empresa no período $t ;$

$D A_{t}{ }^{*} \quad=$ accruals discricionários reais da empresa no período $t$;

O modelo teórico proposto por McNichols e Wilson (1988, p.5) para detectar o gerenciamento dos accruals é apresentado pela seguinte expressão:

$$
D A_{t}^{*}=\phi+\gamma\left(P A R T_{i t}\right)+\varepsilon_{i t} \quad \text { (Equação 3.02) }
$$

em que:

$D A_{t}{ }^{*} \quad=$ accruals discricionários reais da empresa no período $t$;

$P A R T_{i t}=$ conjunto de variáveis particionadas que capturam os fatores que presumidamente motivam o gerenciamento dos accruals na empresa $i$ no período $t$

$\varepsilon_{i, t}=$ fatores aleatórios não relacionados à hipótese específica de gerenciamento de resultados da empresa $i$ no período $t$;

Como a variável DA* não é observável, utilizam-se os modelos empíricos que calculam uma estimativa para accruals discricionários ( $D A$ - discretionary accruals), que é uma medida das acumulações discricionários reais $D A^{*}$ com erro de mensuração $(\eta)$ :

$$
D A_{t}=D A_{t}^{*}+\eta_{t} \quad \text { (Equação 3.03) }
$$

em que:

$D A_{t} \quad=$ accruals discricionários estimados da empresa no período $t$;

$D A_{t}{ }^{*} \quad=$ accruals discricionários reais da empresa no período $t$

$\eta_{t}=$ erro de mensuração dos accruals discricionários da empresa no período $t$.

Enquanto que, os accruals não-discricionários estimados (NDA) são expressos da seguinte forma:

$$
N D A_{t}=N D A_{t}^{*}+\tau_{t} \quad(\text { Equação } 3.04)
$$

em que:

$N D A_{t} \quad=$ accruals não-discricionários estimados da empresa no período $t ;$

$N D A_{t}{ }^{*} \quad=$ accruals não-discricionários reais da empresa no período $t$;

$\tau_{t} \quad=$ erro de mensuração dos accruals não-discricionários da empresa no período $t$. 
Como a variável $D A$ é utilizada no lugar da $D A^{*}$, a equação 3.02 é reescrita da seguinte forma:

$$
D A_{t}=\alpha+\beta(P A R T)_{t}+v_{t} \quad(\text { Equação 3.05) }
$$

Sendo, $\beta$ é igual a:

$$
\beta=\gamma+\rho_{P A R T, \eta} * \sigma_{\eta} / \sigma_{P A R T} \quad \text { (Equação 3.06) }
$$

A expressão $\rho_{P A R T, \pi} * \sigma_{\eta} / \sigma_{P A R T}$ representa o viés em $\beta$ :

$$
\beta=\gamma+\text { viés } \beta \quad \text { (Equação 3.07) }
$$

Quanto menor o viés em $\beta$, mais o estimador $\beta$ representa o valor verdadeiro de $\gamma$. Esse viés de mensuração é acrescido quando:

a) aumenta a correlação entre o erro de mensuração dos accruals discricionários ( $\eta$ ) e o conjunto de variáveis que representam os fatores que supostamente afetam o gerenciamento de resultados através dos accruals (PART);

b) aumenta a variância do erro de mensuração dos accruals discricionários ( $\eta)$;

c) diminui a variância de $P A R T$.

Assim, um viés significativo na estimação dos accruals discricionários, pode conduzir a conclusões sobre resultados gerenciados quando, na realmente, os resultados não são gerenciados.

O coeficiente $\beta$ é utilizado para extrair evidências sobre o gerenciamento de resultados através dos accruals diante da hipótese testada. O termo PART representa a variável dummy que separa as observações em dois grupos: um grupo com os indivíduos (ou observações) que supostamente têm incentivos para gerenciar os resultados contábeis e outro grupo com os indivíduos que supostamente não têm incentivos para gerenciar os resultados contábeis. Após a estimação dos parâmetros, verifica-se se o $\beta$ estimado é significativamente diferente de zero, ou seja, dependendo da hipótese levantada se $\beta>0$ ou $\beta<0$.

Por exemplo: um pesquisador deseja testar se um conjunto de empresas gerencia resultados contábeis para evitar a divulgação de resultados negativos. Separam-se as observações em dois grupos: um grupo com empresas que têm supostamente incentivos para evitar a divulgação de resultados negativos, atribuindo o valor 1 para a variável dummy e, outro grupo com empresas sem tais incentivos, atribui-se o valor 0 . 
Após a estimação dos parâmetros da Equação 3.05 com base na amostra selecionada, tem-se que os accruals discricionários $(D A)$ das empresas com incentivos de gerenciar resultados $(P A R T=1)$ será a soma dos parâmetros estimados $\alpha$ e $\beta$, enquanto os accruals discricionários $(\mathrm{DA})$ das empresas sem incentivos de gerenciar resultados $(P A R T=0)$ será o valor estimado para o parâmetro $\alpha$. No caso de o $\beta$ estimado ser significativamente maior que zero $(\beta>0)$, pode-se considerar que existem evidências de que as empresas gerenciam os resultados contábeis através dos accruals para evitar a divulgação de resultados negativos.

No modelo geral apresentado por McNichols e Wilson (1988), devem ser controlados outros fatores relevantes que afetam o comportamento dos accruals discricionários. A omissão dessas variáveis podem afetar o parâmetro $\beta$, prejudicando as evidências apresentadas. Por exemplo, no caso de empresas em período de crescimento, espera-se que ocorra um aumento natural em alguns accruals, que não se relacionam com incentivos para gerenciamento de resultados.

Assim, pode-se descrever um modelo geral para detecção de gerenciamento de resultados através dos accruals, da seguinte forma (Equação 3.08):

$$
D A_{t}=\alpha+\beta(P A R T)_{t}+\sum_{k=1}^{k} \gamma_{k} X_{k t}+\varepsilon_{t} \quad \text { (Equação 3.08) }
$$

em que:

$D A_{t} \quad=$ accruals discricionários estimados da empresa no período $t ;$

$P A R T_{i t}=$ conjunto de variáveis particionadas que capturam os fatores que presumidamente motivam o gerenciamento dos accruals na empresa $i$ no período $t$

$X_{i t} \quad=$ outros fatores que influenciam o comportamento dos accruals discricionários da empresa $i$ no período $t$;

$\varepsilon_{i, t}=$ fatores aleatórios não relacionados à hipótese específica de gerenciamento de resultados da empresa $i$ no período $t$;

Para Dechow et al (1995, p.196), o modelo geral quando é mal especificado pela omissão de variável, o termo de erro aleatório $\varepsilon$ captura a soma dos efeitos das variáveis relevantes omitidas pelo modelo e o erro na proxy do pesquisador para accruals discricionários $\left(\eta_{t}\right)$, assim como modelos estimados, usando MQO, conduzem a três problemas de inferências estatísticas em testes para gerenciamento de resultados (DECHOW et al, 1995, p.196-197): 
a) Problema 1: gerenciamento de resultados incorretamente atribuído à variável PART Se o gerenciamento de resultados que foi suposto por $P A R T$ não acontecer (verdadeiro $\beta$ é igual a 0) e erro aleatório $\varepsilon$ está correlacionado com $P A R T$, então o coeficiente estimado de $P A R T$ será enviesado longe de zero, aumentando a probabilidade do Erro Tipo I ${ }^{43}$.

b) Problema 2: gerenciamento de resultados causado não intencionalmente por PART Se gerenciamento de resultados que foi suposto por $P A R T$ acontecer (verdadeiro $\beta$ é diferente de 0) e a correlação entre $\varepsilon$ e $P A R T$ é contrária ao sinal para o verdadeiro coeficiente em $P A R T$, então, o coeficiente estimado de $P A R T$ será enviesado em direção a zero, aumentando a probabilidade do Erro Tipo II.

Esse problema surge quando o modelo usado para gerar a proxy dos accruals discricionários $\left(D A_{t}\right)$ não intencionalmente remove alguns ou todos os accruals discricionários. Mediante tais condições, o erro de mensuração na proxy para accruals discricionários $\left(\eta_{t}\right)$ será negativamente correlacionado com a proxy para acumulações discricionárias $\left(D A_{t}\right)$, fazendo com que o coeficiente em PART seja enviesado em direção a zero.

c) Problema 3: teste com baixo poder estatístico

Se $\varepsilon$ não é correlacionado com $P A R T$, então, o $\beta$ não será enviesado. Porém, a exclusão de variáveis relevantes $(X)$ e não correlacionadas conduz para um erro-padrão inflacionado para o coeficiente estimado em PART, aumentando a probabilidade de um Erro Tipo II

Healy (1996, p.108-109) destaca que as motivações para o gerenciamento de resultados por parte dos gestores podem ser ambíguas, o que dificulta o estabelecimento de metodologias mais adequadas para análise do comportamento oportunístico. Em uma amostra de empresas, pode existir uma empresa que age, oportunisticamente, reduzindo os resultados tributáveis para minimizar a carga tributária, enquanto em outra empresa, o administrador eleva os lucros através da mensuração dos accruals para maximizar seus bônus. Ou mesmo, analisando um única empresa dentro de uma série de tempo, a administração pode gerenciar seus resultados, ora para cima com o objetivo de apresentar melhores resultados aos seus investidores, ora para baixo com o intuito de minimizar os custos políticos. Essas situações dificultam a interpretação dos resultados evidenciados nessa linha de pesquisas.

\footnotetext{
${ }^{43}$ O Erro do Tipo I ocorre quando a hipótese nula é rejeitada, quando é verdadeira e o Erro do Tipo II surge quando a hipótese nula não é rejeitada, quando ela é falsa. (NEWBOLD et al, 2002, p.309; ANDERSON et al, 2002, p.327-328).
} 
Arya et al $(1998$, p.8) sugerem que alguns motivos para os resultados fracos e inconsistentes dos modelos são devidos a:

a) Uso de proxies empíricas não confiáveis para a segregação dos resultados gerenciados e não-gerenciados;

b) $\mathrm{O}$ foco de muitos estudos empíricos sobre um único instrumento de gerenciamento de resultados;

c) Interpretação limitada sobre o gerenciamento de resultados;

d) Os incentivos dos gestores cobrem seus vestígios;

e) Os acionistas podem ter incentivos para facilitar que os administradores escondam informações;

f) Duas ou mais situações independentes que induzam o gerenciamento de resultados podem existir simultaneamente, causando ruídos nos resultados das pesquisas.

Portanto, principalmente, os dois primeiros itens referem-se a problemas de especificação do modelo para a detecção de gerenciamento de resultados, sendo que o primeiro está relacionado ao processo de estimação dos accruals discricionários (variável dependente), enquanto o segundo item relaciona-se ao modelo (geral) de detecção de gerenciamento de resultados.

\subsection{Modelos operacionais para estimação dos accruals não-discricionários e discrionários}

Como descrito na seção anterior, o modelo geral para a detecção de gerenciamento de resultados (Equação 3.08) necessita da estimação dos accruals discricionários, pois ela é uma variável não-observável. Mas, conforme os diversos estudos anteriores (DECHOW et al, 1995; ARYA et al, 1998), existem problemas de especificação dos modelos operacionais para a segregação do componente gerenciado e não-gerenciado dos accruals.

Resumidamente, os problemas da escolha das variáveis relevantes estão relacionados à omissão de variáveis relevantes e correlação significativa entre as variáveis independentes e o erro aleatório, que podem gerar estimadores enviesados e ineficientes.

Uma etapa importante para a estimação dos accruals utilizados no modelo para detecção de gerenciamento de resultados, é a escolha das variáveis e suas proxies, que terão como objetivo 
identificar o componente não-gerenciado (accruals não-discricionários) dos resultados e que minimize os problemas de estimação.

Os modelos propostos para a estimação dos accruals para a detecção de gerenciamento de resultados são calculados, geralmente, nos três passos descritos a seguir:

Passo 1 - Estimação dos parâmetros da regressão;

$$
T A_{t}=\alpha+\sum_{k=1}^{k} \beta_{k t} \chi_{t}+\varepsilon_{t} \quad(\text { Equação 3.09) }
$$

em que:

$T A_{t} \quad=$ accruals totais da empresa no período $t$

$\chi_{t} \quad=$ variáveis que representam os fatores relevantes que afetam o comportamento dos accruals totais da empresa no período $t$;

Passo 2 - Calcular os accruals não-discricionários com base nos coeficientes encontrados no primeiro passo (Equação 3.09) e nos valores reais das variáveis explicativas $(\chi)$ de cada observação.

$$
N D A_{t}=\alpha+\sum_{k=1}^{k} \beta_{k t} \chi_{k t} \quad \text { (Equação 3.10) }
$$

em que:

$N D A_{t} \quad=$ accruals não-discricionários da empresa no período $t$;

$\chi_{k t} \quad=$ variáveis que representam os $k$ fatores relevantes que afetam o comportamento dos accruals totais da empresa no período $t$;

Passo 3 - Estimar os accruals discricionários $(D A)$ pela diferença entre os accruals totais e os accruals não-discricionários (Equação 3.10), conforme descrito abaixo (DECHOW et al, 1995, p.203; PAE, 2005, p.9):

$$
D A_{t}=T A_{t}-N D A_{t} \quad \text { (Equação 3.11) }
$$

em que:

$D A_{t} \quad=$ accruals discricionários da empresa no período $t ;$

$T A_{t} \quad=$ accruals totais da empresa no período $t ;$

$N D A_{t}=$ accruals não-discricionários da empresa no período $t ;$ 
A questão, nesse ponto, seria: como mensurar os accruals totais e os accruals nãodiscricionários?

A primeira parte da pergunta foi discutida anteriormente na seção 3.2, no qual foram apresentadas e discutidas as proxies para accruals totais através da abordagem pelo Balanço Patrimonial e pela Demonstração do Fluxo de Caixa. Os trabalhos empíricos que versam sobre o comportamento oportunístico dos gestores sobre os números contábeis, em sua grande maioria, têm utilizado a primeira abordagem (Equação 2.01).

Porém, uma parte relevante da questão permanece: como mensurar os accruals nãodiscricionários?

Os modelos operacionais propostos buscam identificar os componentes não-discricionários através de fatores (variáveis) que expliquem o comportamento dos accruals totais. Cabe salientar que a identificação dessas variáveis deve ser impreterivelmente suportada pela teoria econômica e contábil.

Os principais modelos operacionais para estimação dos accruals discricionários constantes na literatura corrente sobre gerenciamento de resultados são (MARTINEZ, 2001; TUKAMOTO, 2004):

a) Modelo Healy (1985);

b) Modelo DeAngelo (1986);

c) Modelo Jones (1991);

d) Modelo Jones modificado (DECHOW et al, 1995) e

e) Modelo KS (KANG; SIVARAMAKRISHNAN, 1995).

$\mathrm{Na}$ maioria dos trabalhos empíricos, são empregados os modelos de Jones Modificado (DECHOW et al, 1995) e KS (KANG; SIVARAMAKRISHNAN, 1995) para estimar os accruals discricionários, sendo que o primeiro tem maior freqüência na literatura internacional (DECHOW et al, 1995; BURGSTAHLER; DICHEV, 1997; TEOH et al, 1998; HEALY; WAHLEN, 1999; BARTOV et al, 2002; ROOSENBOOM et al, 2003; BARTOV; MOHANRAM, 2004), enquanto segundo tem apresentado melhores resultados no contexto brasileiro (MARTINEZ, 2001).

A abordagem de estimação dos modelos pode ser em séries de tempo e/ou cross-sectional, A estimação dos accruals discricionários através de séries de tempo gera a necessidade de um amplo período de tempo dos dados das empresas para estimar adequadamente os coeficientes específicos. Os pesquisadores (JONES, 1991; DECHOW et al, 1995) têm preferido a abordagem cross-sectional, devido à menor necessidade de um elevado número de dados em 
relação a séries de tempo, entretanto assumem que as empresas dentro de um mesmo setor têm comportamentos semelhantes de accruals esperados ao longo de tempo (PAE, 2005, p.9). Segundo Kang e Sivaramakrishnan (1995, p.354-355), a variável NDA e seu erro de mensuração $\eta$ são obtidos pela regressão dos accruals observados sob um vetor de variáveis $\chi$ que hipoteticamente influenciam NDA. Assim, os autores afirmam que podem existir problemas de mensuração das variáveis $\chi$ utilizadas na Equação 3.09, pois algumas delas não podem ser observadas pelo pesquisador, além do fato de que algumas de suas proxies são provavelmente afetadas pelo gerenciamento de resultados. Adicionalmente, alertam sobre o problema de simultaneidade, porque os regressores $(\chi)$ e regressando $(N D A)$ são conjuntamente determinados pela limitação imposta pelas práticas contábeis.

O erro de mensuração causa problemas de especificação dos modelos, pois o erro de mensuração $\eta$ está correlacionado com os regressores, levando à estimação de parâmetros inconsistentes e enviesam a proxy dos accruals gerenciados. Isso afeta, diretamente, um dos pressupostos do modelo clássico de regressão múltipla, a exogeneidade das variáveis independentes na qual se estabelece que não pode existir correlação entre o erro aleatório e as variáveis independentes $\left(E\left[\varepsilon_{i} \mid x_{i j}\right]=0\right)$. Assim, os coeficientes enviesados podem afetar as inferências estatísticas.

Conseqüentemente, segundo o Teorema de Gauss-Markov, caso ocorra esse problema, as estimativas dos parâmetros da regressão pelo método dos Mínimos Quadrados Ordinários (MQO) não serão os melhores estimadores lineares não-viesados (GREENE, 2003, p.48; WOOLDRIDGE, 2002, p.101).

O problema da simultaneidade ocorre porque parte do resultado contábil está diretamente relacionado ao processo de estimação dos accruals. Essa relação é limitada pela identidade (Equação 1.01), os estimados do MQO aplicados produziram coeficientes inconsistentes estimados com erros padrões incorretos. (KANG; SIVARAMAKRISHNAN, 1995, p.355).

Fields et al (2001. p.292) ponderam os problemas de especificação dos accruals argumentando que mesmo os trabalhos que consideram múltiplas motivações, geralmente, os tratam de forma independente, porém, na prática, os administradores encaram uma variedade de conflitos, o que não sugere ações, freqüentemente, consistentes. Portanto, a dificuldade na especificação de uma metodologia adequada para pesquisas sobre escolhas contábeis está na complexidade das atividades empresarias, isto é, o impacto simultâneo das múltiplas escolhas, múltiplos objetivos, complicações de identificação das relações entre elas e na mensuração das proxies escolhidas. 
Apesar de certas tentativas de generalizações metodológicas, acredita-se que cada empresa tenha um padrão próprio de comportamento dos accruals esperados, conseqüentemente, os modelos propostos que buscam mensurar da melhor maneira os accruals anormais, estão sujeitos a idiossincrasias das empresas.

A seguir são discutidos os modelos existentes para estimação dos accruals na literatura corrente. Os problemas de especificação serão apresentados a cada modelo e, logicamente, espera-se que as propostas mais recentes resolvam ou minimizem os problemas dos modelos anteriores. Entretanto, ocorre que isso faz com que esses modelos recentes sejam discutidos de forma mais detalhada, logo o número de observações a cada modelo tendem a aumentar, pois se torna um processo de aperfeiçoamento.

\subsubsection{Modelo de Healy (1985)}

\section{$\underline{\text { A. Modelo }}$}

Em seu trabalho, Healy (1985) considera os accruals totais médios ponderados pelos ativos totais como medida dos accruals não-discricionários, conforme a Equação abaixo:

$$
N D A_{i t}=\frac{\left(\sum_{t=1}^{T} T A_{i t}\right) / T}{A_{i t-1}} \text { (Equação 3.12) }
$$

em que:

$N D A_{i t} \quad=$ accruals não-discricionários da empresa $i$ no período $t$;

$T A_{i t} \quad=$ accruals totais da empresa $i$ no período $t$;

$\mathrm{T}=$ número de períodos utilizados para estimar os accruals não-discricionários da empresa $i$;

$A_{t-1} \quad=$ ativos totais da empresa no final do período $t-1$.

Os accruals totais são calculados segundo a Equação 2.01 descrita anteriormente. Conforme a Equação 3.11, o montante de accruals discricionários $(D A)$ é encontrado pela diferença entre os accruals totais e os accruals não-discricionários (NDA) segundo o modelo proposto (nesse caso, Equação 3.12).

\section{B. Considerações}

Os principais problemas metodológicos que são observados no modelo Healy (1985) para detecção dos accruals discricionários são: 
a) Não controla adequadamente as mudanças dos accruals discricionários oriundas das condições econômicas;

b) Baseada em médias de accruals discricionários, o modelo não considera mudanças normais nas atividades operacionais decorrentes da sua atuação empresarial, como crescimento das vendas;

c) A variação dos preços em seus produtos e insumos ao longo do tempo pode prejudicar as inferências. Em períodos de inflação relevantes, o modelo gera accruals anormais, independentemente, das escolhas contábeis;

d) Assume que os accruals não-discricionários são constantes no tempo, tendo média zero no período estimado;

e) Não controla o tamanho da empresa.

Existem outros problemas de especificação do modelo Healy (1985), mas devido ao tratamento simplista adotado para a estimação dos accruals não-discricionários e discricionários, foram somente comentados alguns dos mais revelantes. ${ }^{44}$

\subsubsection{Modelo de DeAngelo (1986)}

\section{$\underline{\text { A. Modelo }}$}

O modelo de DeAngelo (1986) mensura os accruals não-discricionários através das primeiras diferenças nos accruals totais, e assumindo que elas têm um valor esperado de zero sob a hipótese nula de não ocorrência de gerenciamento de resultados. Assim, os accruals nãodiscricionários no período $t$ são mensurados pelos accruals totais do período $t$ - 1 divididos pelos ativos totais do período $t$-1 (Equação 3.13):

$$
N D A_{i t}=\frac{T A_{i t-1}}{A_{i t-1}} \quad(\text { Equação 3.13) }
$$

em que:

$N D A_{i t} \quad=$ accruals não-discricionários da empresa $i$ no período $t$;

$T A_{i t} \quad=$ accruals totais da empresa $i$ no período $t$;

$A_{i t-1} \quad=$ ativos totais da empresa no final do período $t-1$.

\footnotetext{
${ }^{44}$ No final da seção 3.4 é apresentado um quadro sintético com os problemas de especificação observados em todos os modelos analisados neste estudo.
} 
Os procedimentos para estimar o montante de accruals discricionários $(D A)$ seguem igualmente aqueles descritos pelo modelo Healy (1985) na seção 3.3.1.

\section{B. Considerações}

Para esse modelo, têm-se como principais problemas de especificação:

a) Não controla adequadamente as mudanças dos accruals discricionários oriundas das condições econômicas;

b) Baseado somente em accruals defasados, o modelo não considera mudanças normais nas atividades operacionais decorrentes da sua atuação empresarial, como crescimento das vendas;

c) A variação dos preços em seus produtos e insumos ao longo do tempo pode prejudicar as inferências;

d) Assume que os accruals não-discricionários são constantes ao longo do tempo, tendo média zero no período estimado;

e) Não controla o tamanho da empresa.

Tanto o modelo DeAngelo, quanto o modelo Healy, têm grande relevância acadêmica pelo pioneirismo, mas partem de pressupostos fracos, como o de que os accruals nãodiscricionários permanecem constantes ao longo do tempo e qualquer variação nos accruals totais pode ser considerada como uma proxy de discricionariedade dos números contábeis.

\subsubsection{Modelo Setorial (1991)}

\section{$\underline{\text { A. Modelo }}$}

Dechow e Sloan (1991) apresentam um modelo para identificar o componente discricionário dos accruals, no qual se relaxa o pressuposto de que eles são constantes ao longo do tempo. $\mathrm{O}$ modelo calcula os accruals não-discricionários assumindo que os fatores determinantes de seu comportamento são semelhantes para as empresas dentro do mesmo setor. O modelo proposto é descrito da seguinte forma (Equação 3.14):

$$
N D A_{i t}=\gamma_{0}+\gamma_{1} \text { mediana }_{t}\left(T A_{t}\right) \quad \text { (Equação 3.14) }
$$

em que:

$N D A_{i t} \quad=$ accruals não-discricionários da empresa $i$ no período $t$; 
$T A_{i t}=$ accruals totais da empresa $i$ no período $t$, ponderados pelos ativos totais no final do período $t-1$;

Os procedimentos para estimar o montante de accruals discricionários $(D A)$ seguem aqueles descritos pelas Equações 3.09 à 3.11 .

\section{B. Considerações}

Têm-se como principais problemas de especificação nesse modelo:

a) Não controla as mudanças dos accruals discricionários oriundas das condições econômicas;

b) Baseado nas medianas dos accruals não-discricionários de cada setor, o modelo não considera as diferenças de estratégias e a estrutura das operações entre as empresas;

c) A variação dos preços em seus produtos e insumos ao longo do tempo pode prejudicar as inferências;

d) A reversão natural dos accruals dos períodos anteriores não é controlada pelo modelo o que pode originar erro de especificação ao modelo, pois os resíduos podem ser serialmente correlacionados.

Na seção 3.1, foi verificado que existe um processo de reversão natural dos accruals, o qual não é observado pelo modelo Setorial, além de outros problemas apresentados no quadro sintético no final da seção 3.4. Apesar de uma tentativa de regredir os accruals nãodiscricionários e certo grau de aperfeiçoamento em relação às propostas anteriores, o modelo não controla uma série de fatores que são relevantes no processo de estimação dos accruals discricionários.

\subsubsection{Modelo de Jones (1991)}

\section{A. Modelo}

Como os modelos Healy (1985) e DeAngelo (1986) consideram que accruals nãodiscricionários são constantes ao longo do período, Jones (1991) propõe um modelo que relaxa esse pressuposto, buscando controlar os efeitos das mudanças no ambiente econômico da firma sobre os accruals não-discricionários através da variação das receitas e do montante 
do imobilizado e diferido. Os accruals não-discricionários pelo modelo de Jones são calculados da seguinte forma (JONES, 1991, p.211):

$$
N D A_{i t}=\alpha\left(\frac{1}{A_{t-1}}\right)+\beta_{1}\left(\Delta R_{i t}\right)+\beta_{2}\left(P P E_{i t}\right) \quad(\text { Equação 3.15) }
$$

em que:

$N D A_{i t} \quad=$ accruals não-discricionários da empresa $i$ no período $t$;

$\Delta R_{i t}=$ variação das receitas líquidas da empresa $i$ do período $t-1$ para o período $t$, ponderada pelos ativos totais no final do período $t-1$;

$P P E_{i t} \quad=$ saldos das contas do Ativo Imobilizado e Ativo Diferido (bruto) empresa $i$ no final do período $t$, ponderados pelos ativos totais no final do período $t-1$;

$A_{i t-1} \quad=$ ativos totais da empresa no final do período $t-1$;

$\alpha, \beta_{1}$ e $\beta_{2}=$ coeficientes estimados da regressão pela Equação 3.16.

As estimativas dos parâmetros dos modelos $\alpha, \beta_{1}$ e $\beta_{2}$ são geradas pelo seguinte modelo:

$$
T A_{i t}=\alpha\left(\frac{1}{A_{t-1}}\right)+\beta_{1}\left(\Delta R_{i t}\right)+\beta_{2}\left(P P E_{i t}\right)+v_{i t} \quad(\text { Equação 3.16) }
$$

em que:

$T A_{i t} \quad=$ accruals totais da empresa $i$ no período $t$, ponderados pelos ativos totais no final do período $t-1$;

$\Delta R_{i t}=$ variação das receitas líquidas da empresa $i$ do período $t-1$ para o período $t$, ponderada pelos ativos totais no final do período $t-1$;

$P P E_{i t} \quad=$ saldos das contas Ativo Imobilizado e Ativo Diferido (bruto) da empresa $i$ no final do período $t$, ponderados pelos ativos totais no final do período $t$ - 1 ;

$A_{i t-1} \quad=$ ativos totais da empresa no final do período $t-1$.

$v_{i t} \quad=$ erro da regressão (resíduos).

Os procedimentos para estimar o montante de accruals discricionários $(D A)$ seguem, igualmente, os descritos pelo modelo Setorial (1991). Porém, os accruals discricionários (anormais) nesse modelo são identificados, também, como sendo o próprio resíduo $\left(v_{i t}\right)$ da regressão descrita na Equação 3.16.

O pressuposto assumido é que as variáveis $P P E$ e $\Delta R$ controlam os accruals não-gerenciados associados, respectivamente, às despesas com depreciação e amortização e mudanças das atividades econômicas da empresa (PEASNELL et al, 2000, p. 314). Jones (1991) considera que todos os accruals, excetuando aqueles relacionados à provisão de despesas com provisão 
de imposto de renda, devem ser considerados nos modelos de detecção de gerenciamento de resultados e, que ao incluir os ativos imobilizados como variáveis exploratórias, ele controla o tamanho da firma.

Espera-se que o coeficiente da variável $P P E$ seja negativo, pois o nível do ativo imobilizado e diferido está relacionado ao decréscimo dos resultados através da apropriação (accruals) das despesas com depreciação e amortização. Por outro lado, o sinal esperado do coeficiente $\Delta R$ é mais ambíguo, pois uma variação das receitas pode causar aumentos em algumas contas do capital circulante e decréscimos em outras contas.

\section{B. Considerações}

O modelo Jones (1991) é um dos modelos mais utilizados nas pesquisas que estimam os accruals anormais, tanto na perspectiva oportunística, quanto na de eficiência, porém diversos estudos questionam a capacidade do modelo Jones na separação adequada da parcela gerenciada e não-gerenciada dos accruals (SUBRAMANYAM, 1996, p.278). Verifica-se que os principais problemas de especificação relacionados a esse modelo são:

a) Continua existindo problemas de simultaneidade entre as variáveis, pois mesmo com a utilização das variáveis $P P E$ e $\triangle R$, o modelo não controla as mudanças causadas pelas condições econômicas;

b) As variáveis utilizadas para controlar o ambiente econômico podem estar contaminadas pelo gerenciamento de resultados;

c) O modelo assume que as receitas não são manipuladas;

d) A variação dos preços em seus produtos e insumos ao longo do tempo pode prejudicar as inferências;

e) O modelo não controla os accruals discricionários relacionados aos custos e despesas ${ }^{45}$, pois essas não são perfeitamente correlacionadas com as receitas, originando problema de variáveis omitidas (KANG; SIVARAMAKRISHNAN, 1995, p. 356);

f) A variável PPE não controla, adequadamente, o tamanho da empresa, podendo tornar os coeficientes enviesados;

g) Empresas com expectativas de crescimento de longo prazo têm, provavelmente, estratégias diferentes sobre investimentos de capital circulante;

\footnotetext{
${ }^{45}$ Exceto as despesas com depreciação e amortização através da variável $P P E$.
} 
h) A reversão natural dos accruals dos períodos anteriores não é controlada pelo modelo o que pode originar erro de especificação ao modelo, pois os resíduos podem ser serialmente correlacionados;

i) A proposta de Jones (1991) não controla desempenhos extremos de fluxo de caixa e de resultados;

j) $\mathrm{O}$ modelo não tem intercepto, assim os coeficientes $\beta$ estimados são estimadores enviesados de $\beta$ real, e o coeficiente de determinação $R^{2}$ não será calculado adequadamente.

Para verificar de forma simplificada, os problemas indicados nos itens $a$ e $c$, tem-se o seguinte exemplo. Considere uma empresa que não tenha crescimento de vendas ao longo de todo o período analisado e que todas as vendas (despesas) realizadas são recebidas (pagas) no período seguinte. As Demonstrações Contábeis estão na Tabela 4, a seguir. Com o objetivo de isolar a variável analisada $\Delta R$, foi considerado que a empresa não possui Ativo Imobilizado no período. Além disso, a partir do ano 2, são inseridos artificialmente accruals de vendas (não ocorridas).

Tabela 4 - $\quad$ Exemplo do Modelo Jones - Demonstrações Contábeis

\begin{tabular}{|c|c|c|c|c|c|c|c|c|c|}
\hline & Ano 0 & Ano 1 & Ano 2 & Ano 3 & Ano 4 & Ano 5 & Ano 6 & Ano 7 & Ano 8 \\
\hline Política de vendas & & $\begin{array}{c}\mathbf{a} \\
\text { prazo }\end{array}$ & $\begin{array}{c}\text { a } \\
\text { prazo }\end{array}$ & $\begin{array}{c}\text { a } \\
\text { prazo }\end{array}$ & $\begin{array}{c}\text { a } \\
\text { prazo }\end{array}$ & $\begin{array}{c}\text { a } \\
\text { prazo }\end{array}$ & $\begin{array}{c}\text { a } \\
\text { prazo }\end{array}$ & $\begin{array}{c}\text { a } \\
\text { prazo }\end{array}$ & $\begin{array}{c}\text { a } \\
\text { prazo }\end{array}$ \\
\hline $\begin{array}{l}\text { DRE } \\
\text { Vendas reais } \\
\text { Vendas manipuladas } \\
\text { Reversão das vendas } \\
\text { manipuladas } \\
\text { CMV } \\
\text { Lucro Líquido (LL) }\end{array}$ & & $\begin{array}{r}(2.400) \\
1.600\end{array}$ & $\begin{array}{r}4.000 \\
50 \\
\\
(2.400) \\
1.650\end{array}$ & $\begin{array}{r}4.000 \\
200 \\
(50) \\
(2.400) \\
1.750\end{array}$ & $\begin{array}{r}4.000 \\
400 \\
\\
(200) \\
(2.400) \\
1.800\end{array}$ & $\begin{array}{r}4.000 \\
800 \\
(400) \\
(2.400) \\
2.000\end{array}$ & $\begin{array}{r}4.000 \\
1.600 \\
(800) \\
(2.400) \\
2.400\end{array}$ & $\begin{array}{r}4.000 \\
3.200 \\
(1.600) \\
(2.400) \\
3.200\end{array}$ & $\begin{array}{r}4.000 \\
6.400 \\
(3.200) \\
(2.400) \\
4.800\end{array}$ \\
\hline $\begin{array}{l}\text { DFC } \\
\text { Recebimentos } \\
\text { Pagamentos } \\
\text { Fluxo de Caixa no } \\
\text { período (FC) }\end{array}$ & & $\begin{array}{l}0 \\
0\end{array}$ & $\begin{array}{l}4.000 \\
2.400 \\
1.600\end{array}$ & $\begin{array}{l}4.000 \\
2.400 \\
1.600\end{array}$ & $\begin{array}{l}4.000 \\
2.400 \\
\\
1.600\end{array}$ & $\begin{array}{l}4.000 \\
2.400 \\
1.600\end{array}$ & $\begin{array}{l}4.000 \\
2.400 \\
\\
1.600\end{array}$ & $\begin{array}{l}4.000 \\
2.400 \\
1.600\end{array}$ & $\begin{array}{l}4.000 \\
2.400 \\
1.600\end{array}$ \\
\hline $\begin{array}{l}\text { Balanço Patrimonial } \\
\text { Caixa } \\
\text { Clientes } \\
\underline{\text { Ativo }}\end{array}$ & $\underline{2.000}$ & $\begin{array}{l}2.000 \\
4.000 \\
6.000 \\
\end{array}$ & $\begin{array}{l}3.600 \\
4.050 \\
7.650 \\
\end{array}$ & $\begin{array}{l}5.200 \\
4.200 \\
9.400 \\
\end{array}$ & $\begin{array}{r}6.800 \\
4.400 \\
11.200 \\
\end{array}$ & $\begin{array}{r}8.400 \\
4.800 \\
13.200 \\
\end{array}$ & $\begin{array}{r}10.000 \\
5.600 \\
15.600 \\
\end{array}$ & $\begin{array}{r}11.600 \\
7.200 \\
18.800 \\
\end{array}$ & $\begin{array}{l}13.200 \\
10.400 \\
23.600 \\
\end{array}$ \\
\hline $\begin{array}{l}\text { Fornecedor } \\
\text { Capital } \\
\text { Lucros Acumulados } \\
\text { Passivo }+P L \\
\end{array}$ & 2.000 & $\begin{array}{l}2.400 \\
2.000 \\
1.600 \\
6.000 \\
\end{array}$ & $\begin{array}{l}2.400 \\
2.000 \\
3.250 \\
7.650 \\
\end{array}$ & $\begin{array}{l}2.400 \\
2.000 \\
5.000 \\
9.400 \\
\end{array}$ & $\begin{array}{r}2.400 \\
2.000 \\
6.800 \\
11.200 \\
\end{array}$ & $\begin{array}{r}2.400 \\
2.000 \\
8.800 \\
13.200 \\
\end{array}$ & $\begin{array}{r}2.400 \\
2.000 \\
11.200 \\
15.600 \\
\end{array}$ & $\begin{array}{r}2.400 \\
2.000 \\
14.400 \\
18.800 \\
\end{array}$ & $\begin{array}{r}2.400 \\
2.000 \\
19.200 \\
23.600 \\
\end{array}$ \\
\hline
\end{tabular}


Conforme indicado na Demonstração de Resultado constante da Tabela 4, que existe a manipulação das vendas a partir do ano 2 , de forma que os resultados contábeis possuam um crescimento a cada ano. Na linha seguinte, considera-se que essas vendas manipuladas foram revertidas contra resultados no exercício seguinte.

Os dados necessários para o modelo Jones (1991) estão na Tabela 5. Calculando a regressão com base nesses dados, tem-se o coeficiente $\Delta R$ igual a 1 (não existe imobilizado).

Tabela 5 - Exemplo do Modelo Jones - Dados para regressão

\begin{tabular}{c|r|c}
\hline & $\begin{array}{c}\text { Accruals Totais } \\
\text { (LL }- \text { FC) }\end{array}$ & $\begin{array}{c}\Delta \boldsymbol{R} \\
\text { (vendas realizadas mais } \\
\text { vendas manipuladas menos a } \\
\text { reversão no período) }\end{array}$ \\
\hline Ano 2 & 50 & 50 \\
Ano 3 & 150 & 150 \\
Ano 4 & 200 & 200 \\
Ano 5 & 400 & 400 \\
Ano 6 & 800 & 800 \\
Ano 7 & 1.600 & 1.600 \\
Ano 8 & 3.200 & 3.200 \\
\hline
\end{tabular}

Conforme a Tabela 6, o valor dos accruals discricionários é igual a zero (exatamente o valor do resíduo). Isso é explicado pelo fato de o modelo Jones ortogonalizar os accruals totais com respeito às variações das receitas e, portanto, extrai esses componentes dos accruals, gerando uma estimativa enviesada de gerenciamento de resultados tendendo a zero (DECHOW et al, 1995, p.199). Mesmo simulando outros exemplos com crescimentos diferentes das vendas, os coeficientes se tornam enviesados, tendendo a zero.

Tabela 6 - $\quad$ Exemplo do Modelo Jones - Estimação dos accruals discricionários

\begin{tabular}{l|r|r|r|r|r|r|r}
\hline & Ano 2 & Ano 3 & Ano 4 & Ano 5 & Ano 6 & Ano 7 & Ano 8 \\
\hline Variação das vendas & 50 & 150 & 200 & 400 & 800 & 1.600 & 3.200 \\
Accruals totais & 50 & 150 & 200 & 400 & 800 & 1.600 & 3.200 \\
Accruals não-discricionários NDA (a) & 50 & 150 & 200 & 400 & 800 & 1.600 & 3.200 \\
Accruals discricionários DA (b) & 0 & 0 & 0 & 0 & 0 & 0 & 0 \\
\hline
\end{tabular}

(a) Equação 3.15: $N D A_{i t}=\alpha\left(1 / A_{t-1}\right)+\beta_{1}\left(\Delta R_{i t}\right)+\beta_{2}\left(P P E_{i t}\right)$

(b) Equação 3.11: $D A_{i t}=T A_{i t}-N D A_{i t}$

Assim, o modelo assume que as receitas não são manipuladas e, se os resultados contábeis são manipulados através das receitas, então, o modelo Jones removerá parte dos resultados gerenciados da proxy dos accruals discricionários.

Adicionalmente, como demonstrado na seção 3.1, os accruals no período $t$ refletem fluxos de caixa passados e futuros da empresa. Na tabela 3, verifica-se que os accruals do período 
corrente são revertidos naturalmente no(s) período(s) subseqüente(s), logo, espera-se que tanto seus componentes gerenciados ou não também sejam revertidos. Tal fato causa um problema de especificação no Modelo Jones pela omissão das variáveis defasadas dos próprios accruals.

Observa-se, também, que o processo de geração dos accruals discricionários altera-se conforme a variação do desempenho do resultado e/ou do fluxo de caixa. Espera-se que as empresas com alto desempenho de caixa gerem um grande volume de accruals negativos, enquanto quelas com grandes lucros tenham maiores accruals positivos, devido às relações assumidas entre resultados, fluxos de caixa e accruals descritas por Dechow e Dichev (2002, p. 39-41).

Além disso, como a constante $\alpha$ do modelo é dividida pelos ativos totais da empresa, essa passa a ser uma variável explicativa do modelo, 'função inversa dos ativos totais', logo o seu coeficiente é estimado normalmente pela regressão igualmente às demais variáveis. Portanto, o modelo não tem intercepto, o que força a regressão passar através da origem, fazendo com

que os coeficientes $\hat{\beta}$ 's ( $\beta$ 's estimados) sejam estimadores enviesados de $\beta$ (real), além de que o cálculo do Coeficiente de Determinação $\left(R^{2}\right)$ necessita da especificação do termo constante, caso contrário não fica garantida a consistência do valor estimado para $R^{2}$, que inclusive pode assumir um valor que não esteja entre 0 e 1. (WOOLDRIDGE, 2002, p. 58-59; GREENE, 2003, p.36-37).

A suposição de que os accruals totais tendem a zero (regressão passando pela origem) é muito restritiva e sem fundamentação teórica adequada, pois conforme já discutido anteriormente, considera-se que, devido ao regime de competência adotado pela Contabilidade, o montante do fluxo de caixa dificilmente será igual ao resultado contábil, esperando que haja algum accrual no período.

Kothari et al (2005,p. 173) sugerem que o termo constante seja incluído no modelo Jones, pois auxilia no controle da heteroscedasticidade que não for suavizada pelo deflator $A_{t-1}$ utilizado nas variáveis $P P E$ e $\triangle R$.

\subsubsection{Modelo Jones Modificado (1995)}

\section{A. Modelo}

Observando que o pressuposto de que as receitas não são gerenciadas, nem sempre é verdadeira, Dechow et al (1995, p.199) alteram o modelo Jones (original). O modelo Jones 
modificado busca reduzir o incremento nas contas a receber pelas variações da vendas, assim levando em consideração a possibilidade de manipulação das vendas a prazo.

Inicialmente, as estimativas dos coeficientes $\alpha, \beta_{1}$ e $\beta_{2}$ são obtidas através do modelo original de Jones (1991), conforme Equação 3.16. No segundo momento, os coeficientes estimados são combinados com os parâmetros do modelo Jones Modificado, descrito na Equação 3.17, para estimar os accruals não-discricionários. Por fim, esse resultado é extraído dos accruals totais e a diferença são os accruals discricionários pelo modelo Jones modificado.

$$
N D A_{i t}=\alpha\left(1 / A_{t-1}\right)+\beta_{1}\left(\Delta R_{i t}-\Delta C R_{i t}\right)+\beta_{2}\left(P P E_{i t}\right) \quad \text { (Equação 3.17) }
$$

em que:

$N D A_{i t} \quad=$ accruals não-discricionários da empresa $i$ no período $t$;

$\Delta R_{i t}=$ variação das receitas líquidas da empresa $i$ do período $t-1$ para o período $t$, ponderada pelos ativos totais no final do período $t-1$;

$\Delta C R_{i t}=$ variação das contas a receber (clientes) da empresa $i$ do período $t-1$ para $o$ período $t$, ponderada pelos ativos totais no final do período $t-1$;

$P P E_{i t} \quad=$ saldos das contas do Ativo Imobilizado e Ativo Diferido (bruto) empresa $i$ no final do período t, ponderados pelos ativos totais no final do período $t-1$;

$A_{i t-1} \quad=$ ativos totais da empresa no final do período $t-1$;

$\alpha, \beta_{1}$ e $\beta_{2}=$ coeficientes estimados da regressão pela Equação 3.13.

Como no segundo estágio do modelo, é incluída uma nova variável $\Delta C R_{i t}$ (Equação 3.17), então, os accruals discricionários não são mais encontrados diretamente pelos resíduos da equação.

\section{B. Considerações}

O modelo modificado de Jones assume a maioria dos problemas do modelo original:

a) $\mathrm{O}$ modelo não controla adequadamente as mudanças causadas pelas condições econômicas, tendo problemas de simultaneidade;

b) As variáveis utilizadas para controlar o ambiente econômico podem estar contaminadas pelo gerenciamento de resultados;

c) $\mathrm{O}$ modelo assume que todas as variações nas vendas a prazo são práticas de gerenciamento de resultados;

d) Empresas com expectativas de crescimento de longo prazo têm, provavelmente, estratégias diferentes sobre investimentos de capital circulante; 
e) A variação dos preços em seus produtos e insumos ao longo do tempo pode prejudicar as inferências;

f) O modelo não controla os accruals discricionários relacionados aos custos e despesas, pois essas não são perfeitamente correlacionadas com as receitas;

g) Os resíduos podem ser serialmente correlacionados, devido à auto-reversão dos accruals;

h) Igualmente ao modelo Jones (1991), o modelo modificado não controla desempenhos extremos de fluxo de caixa e de resultados;

i) $\mathrm{O}$ modelo não tem intercepto, assim os coeficientes $\beta$ estimados são estimadores enviesados de $\beta$ real, e o coeficiente de determinação $R^{2}$ não será calculado adequadamente.

Xiong (2006, p.217) afirma que o modelo Jones Modificado controla as mudanças no ambiente econômico das transações e a política de crédito para vendas. Mas, assim como o modelo Jones (1991), não se pode garantir que todas as condições econômicas são capturadas pelas variáveis explicativas $\triangle R$ e $P P E$. Observa-se que o modelo modificado resolve, parcialmente, o problema da ortogonalidade entre os accruals totais e as variações das receitas, porém, com a utilização da variável $\Delta C R_{i t}$ no segundo estágio do modelo, pressupõem-se que todas as mudanças nas vendas a prazo em um determinado momento é decorrente de gerenciamento de resultados.

Para exemplificar, retorna-se aos dados do exemplo descrito na discussão do modelo Jones (1991). Os coeficientes dos parâmetros da regressão são iguais, o coeficiente $\Delta R$ igual a 1 e $\alpha$ igual a 'zero', pois a diferença está somente o segundo momento do processo de estimação.

Tabela 7 - $\quad$ Exemplo 1 do Modelo Jones modificado - Estimação dos accruals discricionários

\begin{tabular}{l|r|r|r|r|r|r|r}
\hline & Ano 2 & Ano 3 & Ano 4 & Ano 5 & Ano 6 & Ano 7 & Ano 8 \\
\hline Variação das vendas & 50 & 150 & 200 & 400 & 800 & 1.600 & 3.200 \\
Variação de clientes & 50 & 150 & 200 & 400 & 800 & 1.600 & 3.200 \\
Accruals Totais & 50 & 150 & 200 & 400 & 800 & 1.600 & 3.200 \\
Accruals não-discricionários NDA (a) & 0 & 0 & 0 & 0 & 0 & 0 & 0 \\
Accruals discricionários DA (b) & 50 & 150 & 200 & 400 & 800 & 1.600 & 3.200 \\
\hline
\end{tabular}

(a) Equação 3.17: $N D A_{i t}=\alpha\left(1 / A_{t-1}\right)+\beta_{1}\left(\Delta R_{i t}-\Delta C R_{i t}\right)+\beta_{2}\left(P P E_{i t}\right)$

(b) Equação 3.11: $D A_{i t}=T A_{i t}-N D A_{i t}$

A Tabela 7 demonstra que o modelo modificado estima adequadamente, nesse primeiro exemplo, os accruals das vendas manipuladas (accruals discricionários). Porém, observe outro exemplo. Considere uma empresa com crescimento anual de $10 \%$ das vendas sobre o 
período anterior, mantendo-se a mesma margem bruta, sem manipulação de accruals, que $50 \%$ das vendas são recebidas no período seguinte e todos os gastos são pagos no próprio período. As Demonstrações Contábeis estão na Tabela 8 seguir.

Tabela 8 - Exemplo 2 do Modelo Jones Modificado - Demonstrações Contábeis

\begin{tabular}{|c|c|c|c|c|c|c|c|c|c|}
\hline & Ano 0 & Ano 1 & Ano 2 & Ano 3 & Ano 4 & Ano 5 & Ano 6 & Ano 7 & Ano 8 \\
\hline Política de vendas & & $\begin{array}{l}50 \% \text { a } \\
\text { prazo }\end{array}$ & $\begin{array}{l}50 \% \text { a } \\
\text { prazo }\end{array}$ & $\begin{array}{l}50 \% \text { a } \\
\text { prazo }\end{array}$ & $\begin{array}{l}50 \% \text { a } \\
\text { prazo }\end{array}$ & $\begin{array}{l}50 \% \text { a } \\
\text { prazo }\end{array}$ & $\begin{array}{l}50 \% \text { a } \\
\text { prazo }\end{array}$ & $\begin{array}{l}50 \% \text { a } \\
\text { prazo }\end{array}$ & $\begin{array}{l}50 \% \text { a } \\
\text { prazo }\end{array}$ \\
\hline DRE & & & & & & & & & \\
\hline Vendas reais & & 4.000 & 4.400 & 4.840 & 5.324 & 5.856 & 6.442 & 7.086 & 7.795 \\
\hline Vendas manipuladas & & & 0 & 0 & 0 & 0 & 0 & 0 & 0 \\
\hline CMV & & $(2.400)$ & $(2.640)$ & $(2.904)$ & (3.194) & $(3.514)$ & $(3.865)$ & $(4.252)$ & $(4.677)$ \\
\hline Lucro Líquido & & 1.600 & 1.760 & 1.936 & 2.130 & 2.343 & 2.577 & 2.834 & 3.118 \\
\hline DFC & & & & & & & & & \\
\hline Recebimentos & & 2.000 & 4.200 & 4.620 & 5.082 & 5.590 & 6.149 & 6.764 & 7.441 \\
\hline Pagamentos & & 2.400 & 2.640 & 2.904 & 3.194 & 3.514 & 3.865 & 4.252 & 4.677 \\
\hline $\begin{array}{l}\text { Fluxo de Caixa no } \\
\text { período (FC) }\end{array}$ & & $(400)$ & 1.560 & 1.716 & 1.888 & 2.076 & 2.284 & 2.512 & 2.764 \\
\hline Balanço Patrimonial & & & & & & & & & \\
\hline Caixa & 2.000 & 1.600 & 3.160 & 4.876 & 6.764 & 8.840 & 11.124 & 13.636 & 16.400 \\
\hline Clientes & & 2.000 & 2.200 & 2.420 & 2.662 & 2.928 & 3.221 & 3.543 & 3.897 \\
\hline Ativo & $\underline{2.000}$ & $\underline{3.600}$ & $\underline{5.360}$ & $\underline{7.296}$ & $\underline{9.426}$ & $\underline{11.768}$ & $\underline{14.345}$ & $\underline{17.179}$ & $\underline{20.297}$ \\
\hline Fornecedor & & 0 & 0 & 0 & 0 & 0 & 0 & 0 & 0 \\
\hline Capital & 2.000 & 2.000 & 2.000 & 2.000 & 2.000 & 2.000 & 2.000 & 2.000 & 2.000 \\
\hline Lucros Acumulados & & 1.600 & 3.360 & 5.296 & 7.426 & 9.768 & 12.345 & 15.179 & 18.297 \\
\hline Passivo $+P L$ & $\underline{2.000}$ & $\underline{3.600}$ & $\underline{5.360}$ & 7.296 & 9.426 & $\underline{11.768}$ & $\underline{14.345}$ & $\underline{17.179}$ & $\underline{20.297}$ \\
\hline
\end{tabular}

Conforme indicado na Demonstração de Resultado constante na Tabela 8, não existe nenhum tipo de manipulação das vendas (por accruals) e somente o crescimento das contas de resultados originado das atividades normais de expansão da empresa.

Os dados necessários para o modelo Jones Modificado (1995) estão na Tabela 9. Calculando a regressão com base nesses dados têm-se o coeficiente $\Delta R$ igual a 0,5 (não existe imobilizado).

Tabela 9 - $\quad$ Exemplo 2 do Modelo Jones Modificado - Dados para regressão

\begin{tabular}{c|c|c}
\hline & & $\Delta R$ \\
& Accruals Totais & $\begin{array}{c}\Delta R \\
\text { (vendas realizadas } \\
\text { mais vendas } \\
\text { manipuladas) }\end{array}$ \\
\hline Ano 2 & 200 & 400 \\
Ano 3 & 220 & 440 \\
Ano 4 & 242 & 484 \\
Ano 5 & 266 & 532 \\
Ano 6 & 293 & 586 \\
Ano 7 & 322 & 644 \\
Ano 8 & 354 & 709 \\
\hline
\end{tabular}


Tabela 10 -

Exemplo 2 do Modelo Jones Modificado - Estimação dos accruals discricionários

\begin{tabular}{l|r|r|r|r|r|r|r}
\hline & Ano 2 & Ano 3 & Ano 4 & Ano 5 & Ano 6 & Ano 7 & Ano 8 \\
\hline Variação das vendas & 400 & 440 & 484 & 532 & 586 & 644 & 709 \\
Variação de clientes & 200 & 220 & 242 & 266 & 293 & 322 & 354 \\
Accruals Totais & 200 & 220 & 242 & 266 & 293 & 322 & 354 \\
Accruals não-discricionários NDA (a) & 100 & 110 & 121 & 135 & 146 & 161 & 177 \\
Accruals discricionários DA (b) & 100 & 110 & 121 & 135 & 146 & 161 & 177 \\
\hline
\end{tabular}

(a) Equação 3.17: $N D A_{i t}=\alpha\left(1 / A_{t-1}\right)+\beta_{1}\left(\Delta R_{i t}-\Delta C R_{i t}\right)+\beta_{2}\left(P P E_{i t}\right)$

(b) Equação 3.11: $D A_{i t}=T A_{i t}-N D A_{i t}$

A Tabela 10 apresenta as variáveis empregadas e montante dos accruals não-discricionários e discricionários, enquanto a Tabela 11 demonstra a comparação dos accruals reais (discricionários e não-discricionários) com os valores estimados pelo modelo Jones Modificado.

Tabela 11 - $\quad$ Exemplo 2 do Modelo Jones Modificado - Comparação entre os accruals reais e estimados

\begin{tabular}{|c|c|c|c|c|c|c|c|}
\hline & Ano 2 & Ano 3 & Ano 4 & Ano 5 & Ano 6 & Ano 7 & Ano 8 \\
\hline Dados reais & & & & & & & \\
\hline NDA - Vendas/Clientes & 200 & 220 & 242 & 266 & 293 & 322 & 354 \\
\hline NDA - Custos/Fornecedores & 0 & 0 & 0 & 0 & 0 & 0 & 0 \\
\hline NDA - Total & 200 & 220 & 242 & 266 & 293 & 322 & 354 \\
\hline DA & $\underline{0}$ & $\underline{0}$ & $\underline{0}$ & $\underline{0}$ & $\underline{0}$ & 0 & $\underline{0}$ \\
\hline Accruals Totais & 200 & 220 & 242 & 266 & 293 & 322 & 354 \\
\hline Valores estimados & & & & & & & \\
\hline Accruals não-discricionários NDA & 100 & 110 & 121 & 135 & 146 & 161 & 177 \\
\hline Accruals discricionários DA & 100 & 110 & 121 & 135 & 146 & 161 & 177 \\
\hline $\begin{array}{l}\text { Diferença entre accruals reais e } \\
\text { estimados }\end{array}$ & & & & & & & \\
\hline Accruals não-discricionários NDA & 100 & 110 & 121 & 135 & 146 & 161 & 177 \\
\hline Accruals discricionários DA (b) & $(100)$ & (110) & $(121)$ & $(135)$ & $(146)$ & $(161)$ & $(177)$ \\
\hline
\end{tabular}

A diferença entre os accruals reais e estimados é exatamente a variação da conta 'Clientes' multiplicada pelo coeficiente $\beta_{1}$ da regressão $(0,50)$ em cada período. Isso evidencia que toda a variação dessa conta é considerada como gerenciamento de resultados. Considera-se, então, que a utilização da variável $\left(\Delta R_{t}-\Delta C R_{t}\right)$ no segundo momento do modelo Jones Modificado não possui fundamentação econômica muito clara para sua utilização.

Com relação à pesquisa desenvolvida, Dechow et al (1995, p.194-195) afirmam que as pesquisas empíricas têm apresentado como principais percepções:

a) Todos os modelos mostram-se bem especificados quando aplicados em amostras aleatórias de empresas-ano; 
b) Todos os modelos geram testes de baixo poder para gerenciamento de resultados de magnitudes economicamente plausíveis;

c) Todos os modelos rejeitam a hipótese nula de não gerenciamento de resultados a taxas que excedam os níveis de testes específicos quando aplicados à amostra de empresas com extremo desempenho financeiro.

d) O modelo Jones modificado gera menor Erro do Tipo II. ${ }^{46}$

No que se refere ao item a, os autores $(1995$, p.195) apontam que a principal causa do excesso de rejeição da hipótese nula é que "[...] os accruals não-discricionários (que não são extraidos pelos modelos) podem ser correlacionados com o desempenho da firma." ${ }^{47}$. Os resultados da pesquisa apontam que (DECHOW et al, 1995, p.223-224):

a) $\mathrm{O}$ poder dos testes, em relação aos modelos analisados ${ }^{48}$, é relativamente baixo para gerenciamento de resultados com magnitudes economicamente plausíveis, o que implica na necessidade de uma amostra grande de dados;

b) Os incentivos do gerenciamento de resultados estão correlacionados ao desempenho da empresa;

c) É importante observer o contexto no qual o gerenciamento de resultados é hipotetizado e qual o modelo utilizado.

Interessante nessas afirmações é que, aparentemente, os autores sugerem que a utilização de um determinado modelo está condicionada diretamente à hipótese levantada pelo pesquisador, incentivando o emprego de modelos alternativos nos estudos empíricos para que se possam atribuir inferências mais consistentes às hipóteses da pesquisa.

Guay et al (1996, p. 84) e Peasnell et al (2000, p.315) evidenciam que os modelos Jones e Jones Modificado, através de procedimentos de series temporais, não geram uma mensuração confiável dos accruals gerenciados, pois induzem a um erro de mensuração substancial, sendo que, para Gu et al (2005, p.314), essa falha é parcialmente atribuída ao fato de os accruals serem heteroscedásticos.

\footnotetext{
${ }^{46}$ Erro do Tipo I ocorre quando o modelo de mensuração dos accruals discricionários falsamente rejeita a hipótese de gerenciamento de resultados, enquanto que Erro do Tipo II refere-se capacidade de detectar o gerenciamento de resultados realmente acontecido, ou seja, a hipótese nula não é rejeitada, quando ela é falsa.

${ }_{47}$ Tradução livre de: "[...] nondiscretionary accruals (that are not extracted by the models) may be correlated with firm performance."

${ }^{48}$ Os modelos analisados por Dechow et al (1995) foram: Healy (1985), DeAngelo (1986), Jones (1991), Setorial (1991) e Jones Modificado (1995).
} 
Para Peasnell et al (2000, p.315), a versão cross-sectional dos modelos Jones e Jones Modificado, prevalecente na literatura corrente, em substituição à série temporal, apresentam novos problemas, como, por exemplo, menor probabilidade de capturar os efeitos das reversões nos accruals.

\subsubsection{Modelo KS (1995)}

\section{A. Modelo}

Kang e Sivaramakrishnan (1995, p. 353) apontam que uma das maiores preocupações quanto aos procedimentos metodológicos nos estudos empíricos sobre a discricionariedade nos accruals é que as variáveis mais úteis na predição dos componentes não-gerenciados são os próprios números contábeis na qual são, provavelmente, afetados pelo gerenciamento dos resultados.

Os referidos autores sugerem que os modelos anteriores que tentam capturar os accruals discricionários através da modelagem das acumulações totais estão sujeitos aos problemas de simultaneidade, erros de mensuração nas variáveis e omissão de variáveis, reduzindo o poder estatístico e conduzindo a inferências errôneas em relação ao gerenciamento de resultados. (op. cit., p.354).

Para minimizar os erros nas variáveis, Kang e Sivaramakrishnan (1995, p. 355) sugerem que sejam incluídas variáveis explicativas que reflitam a realidade econômica corrente e, assim, apresentam um modelo que utiliza contas contábeis que representam custos e despesas, contas do Balanço Patrimonial para contrapor as mudanças dessas na estrutura patrimonial e, portanto, segundo os mesmos, não utilizando variáveis contaminadas devido à utilização de variáveis instrumentais.

Por esse modelo, os accruals não-discricionários são estimados através da seguinte regressão (Equação 3.18):

$$
T A_{i t}=\phi_{0}+\phi_{1}\left(\delta_{1} R_{i t}\right)+\phi_{2}\left(\delta_{2} D_{i t}\right)+\phi_{3}\left(\delta_{3} P P E_{i t}\right)+\varepsilon_{i t} \quad \text { (Equação 3.18) }
$$

em que:

$T A_{i t} \quad=$ accruals totais da empresa $i$ no período $t$, ponderados pelos ativos totais no final do período $t-1$;

$R_{i t} \quad=$ receitas líquidas da empresa $i$ no período $t$, ponderadas pelos ativos totais no final do período $t-1$; 
$D_{i t} \quad=$ montante dos custos e despesas operacionais da empresa $i$ no período $t$, excluídas as despesas com depreciação e amortização, ponderadas pelos ativos totais no final do período $t-1$;

$P P E_{i t} \quad=$ saldo das contas do Ativo Imobilizado e Ativo Diferido (bruto) empresa $i$ no final do período $t$, ponderadas pelos ativos totais no final do período $t$ - 1 ;

$\delta_{1} \quad=C R_{i, t-1} / R_{i, t-1}$

$\delta_{2} \quad=\left(I N V_{i, t-1}+\right.$ DespAntec $\left._{i, t-1}+C P_{i, t-1}\right) / D_{i, t-1}$

$\delta_{3} \quad=\operatorname{Depr}_{i, t-1} / P P E_{i, t-1}$;

$C R_{i-1 t} \quad=$ saldo da conta duplicatas a receber (clientes) da empresa $i$ no período $t-1$;

$R_{i, t-1} \quad=$ receitas líquidas da empresa $i$ no período $t-1$;

$I N V_{i, t-1}=$ saldo da conta estoques da empresa $i$ no período $t-1$;

DespAntec $_{i, t-1}=$ saldo da conta despesas antecipadas da empresa $i$ no período $t-1$;

$C P_{i, t-1}=$ saldo das contas a pagar no curto prazo da empresa $i$ no período $t-1$;

Depr $_{i, t-1}=$ montante de despesas com depreciação e amortização da empresa $i$ no período $t-1$;

$P P E_{i, t-1}=$ saldo das contas do Ativo Imobilizado e Ativo Diferido (bruto) empresa $i$ no final do período $t-1$;

$\Phi_{0}, \Phi_{1}, \Phi_{2}$ e $\Phi_{3} \quad$ = coeficientes estimados da regressão pela Equação 3.18;

$\varepsilon_{i t} \quad=$ erro da regressão(resíduos).

O valor estimado dos accruals discricionários pode ser calculado através da Equação 3.11 ou diretamente pelo erro da regressão (equação 3.18).

Segundo Kang e Sivaramakrishnan (1995), o modelo utiliza as principais contas de resultados como regressores na sua formulação, buscando minimizar problemas de variáveis omitidas, além de trabalhar com as variações das contas do Balanço Patrimonial para estimar os accruals discricionários, pois as suas mudanças são decorrentes da própria dinâmica do regime de competência (accruals basis).

\section{B. Considerações}

Têm-se as seguintes observações a respeito da especificação do modelo KS:

a) As variáveis utilizadas, inclusive as instrumentais, para controlar o ambiente econômico podem estar contaminadas pelo gerenciamento de resultados;

b) A variação dos preços em seus produtos e insumos ao longo do tempo pode prejudicar as inferências; 
c) Os resíduos podem ser serialmente correlacionados, devido à auto-reversão dos accruals;

d) Igualmente ao modelo Jones (1991) e Jones Modificado (1995), o modelo KS não controla desempenhos extremos de fluxo de caixa e de resultados;

e) O uso de variáveis instrumentais podem não apresentar melhor especificação do modelo para identificar os accruals não-discricionários.

Assim como os demais modelos, o modelo KS também tem problemas com a utilização de variáveis que podem estar contaminadas pelo gerenciamento de resultados, resíduos serialmente correlacionados e falta de controle do desempenho econômico. Entretanto, uma questão nova surge com relação à utilização de variáveis instrumentais (VI) para minimizar os problemas de simultaneidade e erro de mensuração nas variáveis.

Um dos principais problemas de especificação dos modelos operacionais é causado pela correlação entre o termo erro aleatório da equação e as variáveis explicativas. Para que um modelo esteja bem especificado, os valores esperados do erro aleatório não devem ser função do conjunto de variáveis independentes da equação $\left(E\left[\varepsilon \mid x_{j 1}, x_{j 2}, \ldots, x_{j k}\right]=0\right)$, ou seja, nenhuma informação sobre o erro deve estar contida nas variáveis explicativas do modelo (MADDALA, 1992, p.65; WOOLDRIDGE, 2002, p.83; GREENE, 2003, p.10).

Uma forma de corrigir o viés, causado pela não observância da hipótese da exogeneidade das variáveis independentes, é a utilização das variáveis instrumentais (GREENE, 2003, p.74-75). O método das Variáveis Instrumentais, em substituição do método MQO, é desenvolvido através da utilização de uma variável instrumental $\left(z_{i}\right)$ que seja altamente correlacionada com a variável explicativa $\left(x_{i}\right)$ e ao mesmo tempo não correlacionada com o termo de erro $\varepsilon$ da regressão.

É também importante lembrar que todos os instrumentos não são criados igualmente. Instrumentos fracos, ou seja, instrumentos que não predizem muito da variação na variável dependente relevante pode conduzir a inferências não confiáveis no segundo estágio. (ECHAMBADI et al, 2006, p.1804). ${ }^{49}$

Maddala (1992, p.23) indica que existem três propriedades desejáveis para os estimadores: (1) não-enviesados, (2) eficientes e (3) consistentes.

Um estimador é não-enviesado quando a média da distribuição amostral do $\hat{\beta}$ ( $\beta$ estimado) for igual ao verdadeiro $\beta$, ou seja, se calcular o $\hat{\beta}$ para diversas amostras e repetidas vezes, a

\footnotetext{
${ }^{49}$ Tradução livre de: It is also important to remember that all instruments are not created equally. Weak instruments, i.e. instruments that do not predict much variation in the relevant dependent variable may lead to unreliable inferences in the second stage.
} 
média de todos os estimadores será igual a $\beta$. A eficiência refere-se à variância dos estimadores. Quando $\hat{\beta}$ é um estimador não-enviesado e tem uma variância mínima, diz-se que esse é estimador eficiente.

Um estimador é consistente quando a estimativa tende para uma medida que seja calculada quando o tamanho da amostra tende a infinito. Assim, se o tamanho da amostra é suficientemente grande, pode-se confiar que a estimativa converta ao verdadeiro valor. Davidson e MacKinnon (2003, p.92) afirmam que "felizmente, o estimador dos mínimos quadrados $\hat{\beta}$ será, freqüentemente, consistentes mesmo quando ele é enviesado." ${ }_{50}$

No modelo KS não se pode garantir que os instrumentos utilizados sejam sempre correlacionados com as variáveis explicativas e não correlacionados com o erro aleatório e, portanto, nem sempre se terão estimadores consistentes e não-enviesados. Além disso, Pindyck e Rubinfeld (2004, p.211) alertam que "a estimação por variáveis instrumentais garante estimação consistente, mas não garante estimação não-tendenciosa."

Mesmo que as variáveis instrumentais e o erro aleatório não sejam correlacionados e que as variáveis explicativas e instrumentais tenham correlação, positiva ou negativa, os estimadores pelo método de variáveis instrumentais podem conter um erro-padrão grande e, conseqüentemente, serão enviesados quando a correlação entre explicativas e instrumentais for fraca. Nesse caso, a utilização do método MQO é preferível, pois apresenta melhores estimadores ao método VI.

Cabe salientar que $R^{2}$ por VI não possui interpretação natural e pode assumir valor negativo, pois o objetivo do método é produzir melhores estimativas das variáveis independentes sobre a variável dependente, não estando preocupado com o grau de ajuste da regressão (WOOLDRIDGE, 2002, 472-473).

Kang e Sivaramakrishnan $(1995$, p.365) sugerem que não existem razões para limitar as variáveis instrumentais àquelas utilizadas no referido trabalho e indicam que:

Valores defasados dos componentes de resultados, resíduos defasados e certas variáveis contemporâneas (por exemplo, despesas de capitais ou mudanças na dívida de longo prazo) são todas potenciais candidatas. ${ }^{51}$

Assim, os valores defasados podem ser utilizados para reduzir os problemas de especificação do modelo, em particular, resolvendo o problema dos resíduos serem serialmente correlacionados, devido à reversão dos accruals nos períodos seguintes.

\footnotetext{
${ }^{50}$ Tradução livre de: "Happily, the least squares estimator $\hat{\beta}$ will often be consistent even when it is biased."

${ }^{51}$ Tradução livre de: "Lagged values of decomposed income components, lagged residuals, and certain contemporaneous variables (e.g. capital expenditure or changes in long-term debt) are all potential candidates."
} 
Os resultados da pesquisa de Kang e Sivaramakrishnan (1995, p.361) apontam que o modelo proposto por eles é superior e apresenta maior robustez em relação ao Erro do Tipo I em relação ao modelo Jones (1991), pois esse último tem uma forte tendência de rejeitar a hipótese quando as firmas estão tendo variações (positivas ou negativas) no desempenho econômico. Outro resultado importante é que as diferenças no poder estatístico pelo modelo proposto diminuem à medida que o nível de gerenciamento de resultados aumenta. (op.cit., p.354), o que indica que os accruals discricionários são influenciados pelos resultados contábeis e fluxos de caixa das empresas.

\subsubsection{Modelo Marginal (2000)}

\section{A. Modelo}

Peasnell et al (2000, p.315) apresentam um modelo cross-sectional usando dois estágios de procedimentos, em que no primeiro estágio tem-se uma regressão dos accruals contábeis sobre um vetor de variáveis explanatórias com o intuito de capturar o componente gerenciado. A derivação do modelo começa pela apresentação dos accruals do capital de giro (working capital accruals) baseado na variação das contas de estoques, clientes e fornecedores:

$$
W C A_{i t}=\Delta I N V_{i t}+\Delta C R_{i t}-\Delta C P_{i t} \quad \text { (Equação 3.19) }
$$

em que:

$W C A_{i t} \quad=$ accruals do capital de giro da empresa $i$ no período $t$;

$\Delta I N V_{i t}=$ variação da conta Estoques da empresa $i$ do período $t$ - 1 para o período $t$;

$\Delta C R_{i t}=$ variação das contas a receber (clientes) da empresa $i$ do período $t-1$ para $o$ período $t$;

$\Delta C P_{i t} \quad=$ variação das contas a pagar (fornecedores) da empresa $i$ do período $t-1$ para o período $t$.

Sendo que:

$$
\begin{gathered}
\Delta I N V_{i t}=C I_{i t}-C V_{i t} \quad(\text { Equação 3.20) } \\
\Delta C R_{i t}=V P_{i t}-R V P_{i t}-B V P_{i t} \quad(\text { Equação 3.21) } \\
\Delta C P_{i t}=C I_{i t}-P C I_{i t} \quad \text { (Equação 3.22) }
\end{gathered}
$$

em que:

$\Delta I N V_{i t}=$ variação da conta Estoques da empresa $i$ do período $t-1$ para o período $t$,; 
$\Delta C R_{i t} \quad=$ variação das contas a receber (clientes) da empresa $i$ do período $t-1$ para $\mathrm{o}$ período $t$;

$\Delta C P_{i t} \quad=$ variação das contas a pagar (fornecedores) da empresa $i$ do período $t-1$ para $o$ período $t$;

$C I_{i t} \quad=$ montante de compras de insumos da empresa $i$ no período $t$;

$C V_{i t} \quad=$ montante de custos das vendas da empresa $i$ no período $t$;

$V P_{i t} \quad=$ montante das vendas a prazo da empresa $i$ no período $t$;

$R V P_{i t} \quad=$ montante dos recebimentos das vendas a prazo da empresa $i$ no período $t$,;

$B V P_{i t} \quad=$ montante das baixas de vendas a prazo (não recebidas) da empresa $i$ no período $t$

$P C I_{i t}=$ montante dos pagamentos efetuados das compras de insumos da empresa $i$ no período $t$.

Xiong (2006, p.217) reescreve a variação dos accruals do capital de giro (Equação 3.19) da seguinte forma:

$$
\begin{gathered}
W C A_{i t}=\Delta I N V_{i t}+\Delta C R_{i t}-\Delta C P_{i t} \quad(\text { Equação 3.19) } \\
W C A_{i t}=\left(C I_{i t}-C V_{i t}\right)+\left(V P_{i t}-R V P_{i t}-B V P_{i t}\right)-\left(C I_{i t}-P C I_{i t}\right) \\
W C A_{i t}=C I_{i t}-C V_{i t}+V P_{i t}-R V P_{i t}-B V P_{i t}-C I_{i t}+P C I_{i t} \\
W C A_{i t}=-C V_{i t}+V P_{i t}-R V P_{i t}-B V P_{i t}+P C I_{i t} \\
W C A_{i t}=\left(V P_{i t}-C V_{i t}+B V P_{i t}\right)+\left(P C I_{i t}-R V P_{i t}\right) \\
W C A_{i t}=m b V P_{i t}-c b c R V P_{i t} \quad(\text { Equação 3.23) }
\end{gathered}
$$

em que:

$W C A_{\text {it }} \quad=$ accruals do capital de giro da empresa $i$ no período $t$;

$m b V P_{i t} \quad=$ margem bruta sobre as vendas da empresa $i$ no período $t$;

$c b c R V P_{i t}=$ contribuição bruta de caixa dos recebimentos das vendas da empresa $i$ no período $t$.

Peasnell et al (2000, p. 316) consideram que os outros componentes do capital de giro nãocaixa são ortogonais as variáveis a $V P$ e $R V P$ e, portanto, não teriam significância no modelo. O modelo operacional para accruals não-discricionários é apresentado assim (Equação 3.24):

$$
W C A_{i t}=\lambda_{0}+\lambda_{1} R_{i t}+\lambda_{2}\left(R_{i t}-\Delta C R_{i t}\right)+\varepsilon_{i t} \quad \text { (Equação 3.24) }
$$


em que:

$W C A_{i t} \quad=$ accruals do capital de giro da empresa $i$ no período $t$ ponderados pelos ativos totais no final do período $t-1$;

$R_{i t} \quad=$ receitas líquidas da empresa $i$ no período $t$, ponderadas pelos ativos totais no final do período $t-1$;

$\Delta C R_{i t} \quad=$ variação das contas a receber (clientes) da empresa $i$ do período $t-1$ para $o$ período $t$, ponderada pelos ativos totais no final do período $t-1$;

$\varepsilon_{i t} \quad=$ erro da regressão;

$\lambda_{0}, \lambda_{1}$ e $\lambda_{2}=$ coeficientes estimados pela regressão cross-sectional .

Peasnell et al (2000, p.315) consideram que a variável ' $R-\Delta C R$ ' representa uma proxy para $R V P$. O montante de accruals discricionários do capital de giro também pode ser encontrado pelo erro da regressão da Equação 3.24.

\section{B. Considerações}

O modelo Marginal proposto por Peasnell et al (2000) possui os seguintes problemas de especificação:

a) O modelo não controla as mudanças causadas pelas condições econômicas;

b) As variáveis utilizadas para controlar o ambiente econômico podem estar contaminadas pelo gerenciamento de resultados;

c) A variação dos preços em seus produtos e insumos ao longo do tempo pode prejudicar as inferências;

d) O modelo não controla os accruals discricionários relacionados aos custos e despesas, pois essas não são perfeitamente correlacionadas com as receitas;

e) A suposição de que as demais contas do capital circulante operacional são ortogonais as vendas e contas a receber é muito restritiva;

f) Os resíduos podem ser serialmente correlacionados, devido à auto-reversão dos accruals;

g) O modelo não controla os desempenhos extremos de fluxo de caixa e de resultados.

Observa-se que o modelo apresenta, basicamente, os mesmos problemas de especificação dos modelos anteriormente discutidos. Em particular, o Modelo Marginal não utiliza nenhuma variável para identificar os accruals nos resultados da empresa geradas pelas despesas com depreciação e amortização, pois, para Peasnell et al (2000, p.315), esse item tem baixa 
probabilidade de ser manipulado sistematicamente. Mas, esse pressuposto não pode ser generalizado, devendo possuir uma fundamentação mais consistente, pois as despesas de depreciação e amortização podem ser gerenciadas para que a administração atinja os resultados esperados.

Além disso, o modelo baseado somente nas variações das contas de estoques, clientes e fornecedores, ignora itens como salários e arrendamentos no processo de estimação dos accruals. O modelo assume que os outros componentes do capital de giro não-caixa são ortogonais as variáveis a $V P$ e $R V P$. Esse pressuposto não pode ser sempre verdadeiro, pois nem todos os demais componentes do capital circulante operacional terão o mesmo comportamento das receitas e/ou das contas a receber na mudança do nível das vendas.

Com relação ao estudo de Peasnell et al (2000), o objetivo do trabalho foi o de comparar o desempenho do modelo proposto em relação aos modelos Jones e Jones Modificado, quanto à especificação e poder, respectivamente, probabilidade de Erro Tipo I e Erro Tipo II, utilizando os mesmos procedimentos de simulação desenvolvidos por Dechow et al (1995).

Com base em uma amostra de companhias do Reino Unido, os resultados da pesquisa sugerem que os modelos Jones, Jones Modificado e Marginal são bem especificados quando aplicados a uma amostra aleatória de empresas-ano. Entretanto, o modelo Marginal apresentase mais bem especificado quando aplicado a empresas com extremo desempenho de caixa e para detectar manipulação das despesas não relacionadas às dividas incobráveis, enquanto os modelos Jones e Jones Modificado apresentam melhores resultados na detecção de gerenciamento através da manipulação das receitas e das dividas incobráveis. (PEASNELL et al, 2000, p.315).

Deve-se considerar que as comparações diretas dos resultados apresentados nos trabalhos de Dechow et al (1995) e Kang e Shivaramakrishnan (1995) com os descritos por Peasnell et al (2000) são limitadas, pois desenvolvem procedimentos metodológicos diferentes, principalmente, no que se refere ao cálculo dos accruals totais.

Por fim, Peasnell et al (2000, p.326) sugerem que a escolha do modelo para identificar o gerenciamento das acumulações dependerá da forma que se deu a manipulação (através de receitas ou das despesas, por exemplo) e que o uso combinado dos principais modelos pode permitir melhores evidências na detecção do gerenciamento dos accruals. 


\subsubsection{Modelo Jones Forward Looking (2003)}

\section{A. Modelo}

Dechow et $a^{52}$ (2003), baseados em algumas evidências de trabalhos anteriores, realinham o modelo Jones, tentando resolver alguns problemas de especificação. Considerando que o modelo Jones Modificado (1995) assume que todas as variações nas vendas a prazo são estimadas como accruals discricionários, criaram um fator de correção através da regressão, para estabelecer o quanto da mudança da vendas afeta os accruals não gerenciados. Essa correção é dada pela equação abaixo, sendo calculada por setor de atividade econômica:

$$
\Delta C R_{i t}=\alpha+k \Delta R_{i t} \quad \text { (Equação 3.25) }
$$

em que:

$\Delta C R_{i t} \quad=$ variação das contas a receber (clientes) da empresa $i$ do período $t-1$ para $\mathrm{o}$ período $t$, ponderada pelos ativos totais no final do período $t-1$;

$\Delta R_{i t}=$ variação das receitas líquidas da empresa $i$ do período $t-1$ para o período $t$, ponderada pelos ativos totais no final do período $t-1$.

O coeficiente de regressão $k$ captura as variações esperadas nas contas a receber devido à mudança nas vendas. No modelo de estimação dos accruals, também, é incluída uma variável de controle que representa o crescimento das vendas, pois se espera que a empresa que está em crescimento e planeja aumentar as vendas nos períodos futuros, racionalmente, aumenta alguns de seus ativos, como, por exemplo, os estoques (DECHOW et al, 2003, p.359).

Outro ajuste é em relação aos valores defasados dos accruals totais devido ao processo de reversão natural. Em trabalho anterior, Chambers $(1999$, p.10) acolhe as sugestões de Guay et al (1996) e Beneish (1997) para incluir uma variável de controle para reversão temporal dos accruals. Então, Dechow et al (2003) empregam a mesma variável defasada dos accruals utilizada por Chambers (1999).

Além do mais, os autores diferentemente dos modelos Jones (1991) e Jones Modificado (1995), apresentam o termo constante na especificação do modelo. Por fim, com esses ajustes o modelo Jones, denominado pelos próprios autores (DECHOW et al, 2003) como Modelo Jones Forward Looking, é descrito pela seguinte equação:

\footnotetext{
${ }^{52}$ Cabe esclarecer que em Dechow et al (1995), os autores são Patrícia M.Dechow, Richard G. Sloan e Amy P. Sweeney, enquanto em Dechow et al (2003) são Patricia M. Dechow, Scott A. Richardson e Irem Tuna.
} 
$T A_{i t}=\alpha+\beta_{1}\left[(1+k) \Delta R_{i t}-\Delta C R_{i t}\right]+\beta_{2}\left(P P E_{i t}\right)+\beta_{3} \operatorname{Lag}\left(T A_{i t}\right)+\beta_{4}\left(C r R_{i t+1}\right)+\varepsilon_{i t}$ (Equação 3.26) em que:

$T A_{i t} \quad=$ accruals totais da empresa $i$ no período $t$, ponderados pelos ativos totais no final do período $t-1$;

$\Delta R_{i t}=$ variação das receitas líquidas da empresa $i$ do período $t-1$ para o período $t$, ponderada pelos ativos totais no final do período $t-1$;

$\Delta C R_{i t}=$ variação das contas a receber (clientes) da empresa $i$ do período $t-1$ para $o$ período $t$, ponderada pelos ativos totais no final do período $t-1$;

$P P E_{i t} \quad=$ saldos das contas do Ativo Imobilizado e Ativo Diferido (bruto) empresa $i$ no final do período $t$, ponderados pelos ativos totais no final do período $t-1$;

$\operatorname{Lag}\left(T A_{i t}\right)=$ accruals totais da empresa $i$ no período $t$ - 1 , ponderados pelos ativos totais no final do período $t$-2 (accruals totais defasados);

$\mathrm{CrR}_{i t+1}=$ crescimento das vendas no próximo período, calculada através da variação das receitas líquidas da empresa $i$ do período $t$ para o período $t+1$, ponderado pelas receitas líquidas da empresa $i$ do período $t$;

$k=$ fator de correção, que captura as variações esperadas nas contas a receber, devido à variação das receitas líquidas da empresa $i$ do período $t-1$ para o período $t$ ponderada pelos ativos totais no final do período $t-1$;

$\varepsilon_{i t} \quad=$ erro da regressão;

$\alpha, \beta_{1}, \beta_{2}, \beta_{3}$ e $\beta_{4} \quad=$ coeficientes estimados da regressão pela Equação 3.26.

Observa-se que os três primeiros termos da regressão são semelhantes ao modelo Jones Modificado, exceto pelo fator de correção $(1+\mathrm{k})$ e pelo termo constante $\alpha$ não ser dividido pelo ativo total do período anterior. Outro ponto é que os coeficientes são estimados pelo próprio modelo (Equação 3.26), e não pelo modelo Jones (1991).

\section{B. Considerações}

O modelo Jones Forward Looking assume parte dos problemas do modelo original:

a) As variáveis utilizadas para controlar o ambiente econômico podem estar contaminadas pelo gerenciamento de resultados;

b) As empresas com expectativas de crescimento de longo prazo têm, provavelmente, estratégias diferentes sobre investimentos de capital circulante; 
c) A variação dos preços em seus produtos e insumos ao longo do tempo pode prejudicar as inferências;

d) O modelo não controla os accruals discricionários relacionados aos custos e despesas, pois essas não são perfeitamente correlacionadas com as receitas;

e) O modelo não controla diretamente os desempenhos extremos de resultados e de fluxos de caixa;

f) Os accruals discricionários e não-discricionários, provavelmente, têm comportamentos diferentes no processo de reversão.

\subsubsection{Modelo Pae (2005)}

\section{$\underline{\text { A. Modelo }}$}

Baseado nos trabalhos de Dechow (1994), Barth et al (2001) e Dechow e Dichev (2002) que consideram que os accruals contábeis estão sistematicamente relacionados com o fluxo de caixa operacional da empresa, e nos trabalhos de Healy (1996) e Beneish (1997) que tratam da propriedade das reversões dos accruals ao longo do tempo, Pae (2005) amplia o modelo Jones (1991) para estimação dos accruals discricionários para detecção do gerenciamento de resultados.

Como accruals correntes são associados com o fluxo de caixa operacional e accruals dos períodos anteriores, seus componentes podem ser decompostos em acumulações esperadas e não-esperadas.

O objetivo de Pae (2005, p.6) é aumentar o poder preditivo dos modelos Jones e Jones Modificado através da inclusão de variáveis que representem o fluxo de caixa operacional e a reversão natural dos accruals anteriores.

O modelo geral proposto por Pae (2005), denominado neste trabalho de modelo Pae, pode ser descrito da seguinte forma (Equação 3.27):

$$
T A_{i t}=\alpha\left(\frac{1}{A_{t-1}}\right)+\beta_{1}\left(\Delta R_{i t}\right)+\beta_{2}\left(P P E_{i t}\right)+\lambda_{1}\left(F C O_{i t}\right)+\lambda_{2}\left(F C O_{i t-1}\right)+\lambda_{3}\left(T A_{i t-1}\right)+\varepsilon_{i t} \text { (Equação 3.27) }
$$

em que:

$T A_{i t} \quad=$ accruals totais da empresa $i$ no período $t$, ponderados pelos ativos totais no final do período $t-1$;

$A_{i t-1} \quad=$ ativos totais da empresa no final do período $t-1$; 
$\Delta R_{i t} \quad=$ variação das receitas líquidas da empresa $i$ do período $t-1$ para o período $t$, ponderada pelos ativos totais no final do período $t-1$;

$P P E_{i t} \quad=$ saldos das contas Ativo Imobilizado e Ativo Diferido (bruto) da empresa $i$ no final do período $t$, ponderados pelos ativos totais no final do período $t-1$;

$F C O_{i t}=$ fluxo de caixa operacional da empresa $i$ no período $t$, ponderado pelos ativos totais no final do período $t-1$;

$F C O_{i t-1}=$ fluxo de caixa operacional da empresa $i$ no período $t$-1, ponderado pelos ativos totais no final do período $t-2$;

$T A_{i t-1}=$ accruals totais da empresa $i$ no período $t$ - 1 , ponderados pelos ativos totais no final do período $t-2$;

$\varepsilon_{i t} \quad=$ erro da regressão;

$\alpha, \beta_{1}, \beta_{2}, \lambda_{1}, \lambda_{2}$ e $\lambda_{3}=$ coeficientes estimados da regressão pela Equação 3.27.

Os coeficientes $\alpha, \beta_{1}, \beta_{2}, \lambda_{1}, \lambda_{2}$ e $\lambda_{3}$ do modelo são estimados pela regressão cross-sectional. Os procedimentos para estimar os accruals discricionários são os mesmos do Modelo Jones (1991). Pae (2005, p.21) considera ainda que uma forma alternativa para incorporar os accruals defasados seria a utilização das variáveis $\Delta R E V_{i t-1}$ (variação das receitas líquidas da empresa $i$ do período $t-2$ para o período $t-1$ ) e $P P E_{i t-1}$ (saldos das contas Ativo Imobilizado e Ativo Diferido (bruto) da empresa $i$ no final do período $t-1$ ).

\section{$\underline{\text { B. Considerações }}$}

O modelo Pae (2005) incorpora parte das críticas do modelo original de Jones (1991):

a) As variáveis utilizadas para controlar o ambiente econômico podem estar contaminadas pelo gerenciamento de resultados;

b) A variação dos preços em seus produtos e insumos ao longo do tempo pode prejudicar as inferências;

c) Assim como o modelo Jones, considera que as receitas não são gerenciadas;

d) O modelo não controla os accruals discricionários relacionados aos custos e despesas, podendo originar problema de variáveis omitidas;

e) O modelo não tem intercepto, assim os coeficientes $\beta$ 's e $\lambda$ 's estimados são estimadores enviesados de $\beta$ 's e $\lambda$ 's reais, e o Coeficiente de Determinação $R^{2}$ não será calculado adequadamente;

f) A inclusão conjunta das variáveis fluxos de caixa corrente e defasado podem apresentar problemas de especificação. 
Nesse modelo, as mudanças causadas pelas condições econômicas, aparentemente, podem ser controladas pela inclusão das variáveis $C F_{i t}$ e $C F_{i t-1}$, porém outros fatores podem afetar os accruals, como, por exemplo, a magnitude do resultado corrente. Além disso, o pesquisador deve verificar se não existem problemas de multicolinearidade com o emprego dessas variáveis.

Um problema relevante, principalmente quando do estudo comparativo sobre o poder preditivo de modelos concorrentes, é a falta de intercepto no modelo Pae, pois o termo constante $\alpha$ é dividido pelos ativos totais da empresa, fazendo com que a regressão passe pela origem. Como exposto anteriormente nos modelos Jones e Jones Modificado, nesse caso, os coeficientes $\hat{\beta}$ 's ( $\beta$ estimados) e $\lambda$ 's ( $\lambda$ 's estimados) são enviesados e o valor calculado para $R^{2}$ pode ser inconsistente.

Além disso, os fluxos de caixa corrente e defasado têm correlação com os accruals defasados, então, o modelo pode ter problemas de multicolineariedade entre essas variáveis.

No estudo, Pae (2005, p.14-17) avalia o poder preditivo das várias alternativas de ampliação do modelo Jones (1991) e Jones Modificado (1995), com a inclusão somente dos accruals totais defasados $\left(T A_{i t-1}\right)$, com a inclusão dos fluxos corrente e anterior do caixa operacional $\left(C F_{i t}\right.$ e $\left.C F_{i t-1}\right)$ e, por fim, com a inclusão conjunta de todas as três variáveis.

A capacidade preditiva dos modelos propostos foi avaliada por Pae $(2005$, p.11) através de pseudo $R^{2}$, definido como:

$$
R^{2}=1-\frac{\sum(F E)^{2}}{\sum\left(T A-\text { média }^{2}(T A)\right)^{2}} \quad \text { (Equação 3.28) }
$$

em que:

FE = erro de previsão, medida pela diferença entre accruals totais reais e as estimadas;

$T A=$ accruals totais reais.

Com a inclusão dos fluxos de caixa operacional corrente e anterior, o modelo proposto apresentou melhor poder de explicação do que modelos Jones (1991) e Jones Modificado (1995), enquanto accruals defasados não foram significantes na especificação do modelo (PAE, 2005, p.13), o que pode ser explicado pela correlação com o fluxo de caixa corrente ou defasado, conforme discutido anteriormente. Os modelos Jones (1991) e Jones Modificado apresentaram resultados muito similares. 
Adicionalmente ao trabalho, também, foi examinado como o mercado precifica os accruals não-esperados. Assim como Subramanyam (1996) e Guay et al (1996), Pae (2005) evidencia que existe uma associação positiva entre o retorno das ações e os accruals não-esperados depois de controlar o fluxo de caixa operacional e os accruals esperados, assim as acumulações não-esperadas têm, em média, conteúdo informativo sobre retorno das ações.

\subsubsection{Outras considerações sobre os modelos propostos para estimação dos accruals}

$\mathrm{Na}$ literatura acadêmica nos últimos tempos, segregar, adequadamente, os accruals em discricionários e não-discricionários, tem sido uma das tarefas mais difíceis para os pesquisadores. Refinamentos aos modelos propostos estão sendo apresentados em diversas publicações especializadas.

Thomas e Zhang (2000) analisaram os modelos operacionais propostos para identificar os accruals discricionários e, baseados em $R^{2}$ ajustado, evidenciaram que somente o modelo KS tem um desempenho moderadamente bom, sendo que os demais modelos desenvolvidos (até então) têm baixo poder preditivo.

Teoh et al (1998) propõem a separação dos accruals em curto e longo prazo, baseado no pressuposto de que eles têm comportamentos diferentes. $O$ fato é que, os modelos operacionais atualmente existentes se concentram basicamente nos accruals que têm efeito de curto prazo. McNichols (2000, p.315) considera relevante controlar o crescimento de resultados esperados nos modelos de accruals agregados.

Segundo Kang e Sivaramakrishnan (1995, p.359) os accruals não-discricionários podem ser estimados com base no lucro antes (abordagem que ignora accruals gerenciados na despesa tributária reportada) ou depois da tributação (abordagem que induz para uma interferência adicional para os créditos tributários e os efeitos dos accruals gerenciados sobre as despesas tributárias).

Sobre a análise das propriedades da variabilidade dos accruals, Gu et al (2005) indicam que essas estão relacionados com fatores econômicos referentes às características da firma e ao ambiente de disclosure. Os autores (op. cit., p.318) relacionam os seguintes fatores econômicos que afetam a variabilidade dos accruals: tamanho da firma, alavancagem, variabilidade do fluxo de caixa, ciclo operacional, crescimento, resultados negativos, idade da 
firma, negociação no mercado de capitais, tendência temporal, regulação, setor, qualidade da auditoria e opinião do auditor qualificado.

Um outro questionamento sobre os modelos de accruals agregados é sobre o pressuposto de que os accruals discricionários são ortogonais aos não-discricionários, pois, em certos cenários pode existir correlação entre eles, o que torna essa suposição restritiva em alguns estudos (GUAY et al, 1996, p.91; HEALY, 1996, p.112; McNICHOLS, 2000, p.323). Guay et al (1996) e McCulloch e Black (2000) verificaram que existe uma correlação negativa entre os accruals discricionários e os não-discricionários.

Healy (1996, p.113) aponta que o conservadorismo contábil afeta o processo de mensuração dos accruals, enquanto Dechow et al (2003) evidenciam que os accruals discricionários são menos persistentes do que os não-discricionários. Lara et al (2005) evidenciaram que as mensurações do nível de conservadorismo pelo modelo proposto por Basu (1997) são afetadas pelo comportamento discricionário dos números contábeis. O modelo de Basu (1997) pode ser descrito da seguinte forma:

$$
\frac{X_{i t}}{P_{i t}}=\alpha_{0}+\alpha_{1} D R_{i t}+\beta_{0} R_{i t}+\beta_{1} R_{i t}^{*} D R_{i t}+\varepsilon_{i t} \quad \text { (Equação 3.29) }
$$

em que:

$X_{i t} \quad=$ lucro líquido contábil por ação da empresa $i$ no ano $t$;

$P_{i t} \quad=$ preço por ação da empresa $i$ no início do ano $t$;

$R_{i t} \quad=$ retorno econômico por ação da empresa $i$ no ano $t$;

$D R_{i t} \quad=$ variável dummy para indicar se o retorno é negativo; assumindo valor 1 se $R_{i t}$ $<0$, e 0 nos demais casos;

$\varepsilon_{i t} \quad=$ erro da regressão.

Nesse modelo, o coeficiente $\beta_{1}$ deve capturar a diferença do reconhecimento entre as boas e más notícias, porém esse coeficiente pode ser enviesado na presença de gerenciamento de resultados, o que pode conduzir a considerações equivocadas sobre o comportamento conservador nos estudos nessa linha de pesquisa.

Então, a presença do conservadorismo nos números contábeis compromete o comportamento linear assumido nos modelos propostos para identificação dos accruals discricionários.

Por outro lado, observando os accruals discricionários pela abordagem de eficiência, diversos trabalhos (DECHOW, 1994; SUBRAMANYAM, 1996; GUAY et al, 1996; PAE, 2005) identificam que eles são precificados pelo mercado, e servem para reduzir a variabilidade dos resultados, sendo interpretados pelos investidores como um processo de sinalização. 
Subramanyam (1996) evidencia que o componente discricionário dos accruals é positivamente relacionado com os fluxos de caixa futuros, consistente com a correlação estabelecida por Dechow e Dichev (2002).

Outro ponto que deve ser observado é que os accruals são afetados, também, pelo gerenciamento de resultados através das atividades operacionais, fato esse que deve ser controlado no processo de estimação dos accruals discricionários e não-discricionários.

Diante da exposição dos diversos fatores que afetam o processo de mensuração dos accruals e que, conseqüentemente, afetam a segregação do componente gerenciado e não-gerenciado, apresenta-se um quadro comparativo entre os modelos propostos para estimação dos accruals analisados neste trabalho, no qual se sintetizam os principais problemas de cada modelo (Quadro 01).

Quadro 01 - Síntese dos problemas de especificação do modelo de estimação dos accruals

\begin{tabular}{|c|c|c|c|c|c|c|c|c|c|c|}
\hline $\mathrm{N}$ & PROBLEMAS DE ESPECIFICAÇÃO DO MODELO & $\mathrm{A}$ & $\mathrm{B}$ & $\mathrm{C}$ & $\mathrm{D}$ & $\mathrm{E}$ & $\mathrm{F}$ & $\mathrm{G}$ & $\mathrm{H}$ & I \\
\hline 1 & $\begin{array}{l}\text { Controla adequadamente as mudanças dos accruals discricionários oriundas } \\
\text { das condições econômicas }\end{array}$ & $\mathrm{N}$ & $\mathrm{N}$ & $\mathrm{N}$ & $\mathrm{N}$ & $\mathrm{N}$ & $\mathrm{P}$ & $\mathrm{N}$ & $\mathrm{P}$ & $\mathrm{P}$ \\
\hline 2 & $\begin{array}{l}\text { Considera mudanças normais nas atividades operacionais decorrentes da sua } \\
\text { atuação empresarial }\end{array}$ & $\mathrm{N}$ & $\mathrm{N}$ & $\mathrm{N}$ & $\mathrm{P}$ & $\mathrm{P}$ & $\mathrm{S}$ & $\mathrm{N}$ & $\mathrm{P}$ & $\mathrm{P}$ \\
\hline 3 & Controla a variação dos preços ao longo do tempo & $\mathrm{N}$ & $\mathrm{N}$ & $\mathrm{N}$ & $\mathrm{N}$ & $\mathrm{N}$ & $\mathrm{N}$ & $\mathrm{N}$ & $\mathrm{N}$ & $\mathrm{N}$ \\
\hline 4 & $\begin{array}{l}\text { Assume que os accruals não-discricionários não são constantes ao longo do } \\
\text { tempo }\end{array}$ & $\mathrm{N}$ & $\mathrm{N}$ & $\mathrm{S}$ & $\mathrm{S}$ & $\mathrm{S}$ & $\mathrm{S}$ & $\mathrm{S}$ & S & $\mathrm{S}$ \\
\hline 5 & $\begin{array}{l}\text { Considera as diferenças de estratégias e a estrutura das operações entre as } \\
\text { empresas }\end{array}$ & $\mathrm{N}$ & $\mathrm{N}$ & $\mathrm{N}$ & $\mathrm{P}$ & $\mathrm{P}$ & $\mathrm{S}$ & $\mathrm{N}$ & $P$ & $\mathrm{~S}$ \\
\hline 6 & A reversão natural dos accruals dos períodos anteriores é controlada & $\mathrm{N}$ & $\mathrm{N}$ & $\mathrm{N}$ & $\mathrm{N}$ & $\mathrm{N}$ & $\mathrm{N}$ & $\mathrm{N}$ & $\mathrm{S}$ & $\mathrm{S}$ \\
\hline 7 & Controla desempenhos extremos de fluxo de caixa & $\mathrm{N}$ & $\mathrm{N}$ & $\mathrm{N}$ & $\mathrm{N}$ & $\mathrm{N}$ & $\mathrm{N}$ & $\mathrm{N}$ & $\mathrm{N}$ & $\mathrm{S}$ \\
\hline 8 & Controla desempenhos extremos dos resultados & $\mathrm{N}$ & $\mathrm{N}$ & $\mathrm{N}$ & $\mathrm{N}$ & $\mathrm{N}$ & $\mathrm{N}$ & $\mathrm{N}$ & $\mathrm{N}$ & $\mathrm{N}$ \\
\hline 9 & $\begin{array}{l}\text { As variáveis utilizadas para controlar os fatores econômicos relevantes são } \\
\text { imunes a contaminação do próprio gerenciamento de resultados }\end{array}$ & $\mathrm{N}$ & $\mathrm{N}$ & $\mathrm{N}$ & $\mathrm{N}$ & $\mathrm{N}$ & $\mathrm{N}$ & $\mathrm{N}$ & $\mathrm{N}$ & $\mathrm{N}$ \\
\hline 10 & Controla os accruals discricionários relacionados aos custos e despesas & $\mathrm{N}$ & $\mathrm{N}$ & $\mathrm{N}$ & $\mathrm{N}$ & $\mathrm{N}$ & $\mathrm{S}$ & $\mathrm{N}$ & $\mathrm{N}$ & $\mathrm{N}$ \\
\hline 11 & Controla diretamente o tamanho da empresa & $\mathrm{N}$ & $\mathrm{N}$ & $\mathrm{N}$ & $\mathrm{S}$ & $\mathrm{S}$ & $\mathrm{S}$ & $\mathrm{P}$ & $\mathrm{S}$ & $\mathrm{S}$ \\
\hline 12 & O modelo tem intercepto & $*$ & $*$ & $\mathrm{~S}$ & $\mathrm{~N}$ & $\mathrm{~N}$ & $\mathrm{~S}$ & $\mathrm{~S}$ & $\mathrm{~S}$ & $\mathrm{~N}$ \\
\hline 13 & $\begin{array}{l}\text { Considera que as receitas podem ser gerenciadas no momento do } \\
\text { reconhecimento }\end{array}$ & $*$ & $*$ & $*$ & $\mathrm{~N}$ & $\mathrm{~S}$ & $\mathrm{~S}$ & $\mathrm{~S}$ & $\mathrm{~S}$ & $\mathrm{~N}$ \\
\hline 14 & $\begin{array}{l}\text { Não assume que todas as variações nas vendas a prazo são práticas de } \\
\text { gerenciamento de resultados }\end{array}$ & $*$ & $*$ & $*$ & $*$ & $\mathrm{~N}$ & $*$ & $\mathrm{~S}$ & $\mathrm{~S}$ & $\mathrm{~S}$ \\
\hline 15 & Considera os accruals que têm efeitos de longo prazo. & $\mathrm{N}$ & $\mathrm{N}$ & $\mathrm{N}$ & $\mathrm{N}$ & $\mathrm{N}$ & $\mathrm{N}$ & $\mathrm{N}$ & $\mathrm{N}$ & $\mathrm{N}$ \\
\hline 16 & Controla resultados negativos & $\mathrm{N}$ & $\mathrm{N}$ & $\mathrm{N}$ & $\mathrm{N}$ & $\mathrm{N}$ & $\mathrm{N}$ & $\mathrm{N}$ & $\mathrm{N}$ & $\mathrm{N}$ \\
\hline 17 & $\begin{array}{l}\text { Assume o pressuposto de que os accruals discricionários não são ortogonais } \\
\text { aos não-discricionários }\end{array}$ & $\mathrm{N}$ & $\mathrm{N}$ & $\mathrm{N}$ & $\mathrm{N}$ & $\mathrm{N}$ & $\mathrm{N}$ & $\mathrm{N}$ & $\mathrm{N}$ & $\mathrm{N}$ \\
\hline 18 & Controla o conservadorismo contábil no processo de mensuração dos accruals & $\mathrm{N}$ & $\mathrm{N}$ & $\mathrm{N}$ & $\mathrm{N}$ & $\mathrm{N}$ & $\mathrm{N}$ & $\mathrm{N}$ & $\mathrm{N}$ & $\mathrm{N}$ \\
\hline $\begin{array}{c}1-1 \\
\mathrm{~A}-1 \\
\mathrm{C}- \\
\mathrm{E}- \\
\mathrm{G}- \\
\mathrm{I}- \\
2- \\
\mathrm{S}-\end{array}$ & $\begin{array}{lr}\text { da: } & \\
\text { Modelos analisados neste estudo: } & \\
\text { Modelo Healy (1985) } & \text { B - Mode } \\
\text { Modelo Setorial (1991) } & \text { D - Mode } \\
\text { Modelo Jones Modificado (1995) } & \text { F - Mode } \\
\text { Modelo Marginal (2000) } & \text { H - Mode } \\
\text { Modelo Pae (2005) } & \\
\text { Problema de especificação do modelo: } & \\
\text { Sim N N - Não } & \text { P - Parcialmente }\end{array}$ & & & & & & & & & \\
\hline
\end{tabular}




\subsection{Modelos para detecção de gerenciamento de resultados através das atividades operacionais}

\section{$\underline{\text { A. Modelos }}$}

A manipulação dos resultados através das atividades reais é avaliada pela mensuração de contas contábeis do Balanço Patrimonial e da Demonstração de Resultados do Exercício que possam representar certos níveis das atividades operacionais da empresa. Os modelos buscam mensurar os níveis normais das atividades operacionais através dos números contábeis e o erro da estimativa representa um nível anormal das atividades reais da empresa, sendo, assim, uma proxy para essa forma de gerenciamento. Gunny (2005), Zang (2005) e Roychowdhury (2006) investigam essa forma de manipulação através dos padrões de algumas proxies para as atividades operacionais das firmas.

Neste trabalho, apesar da apresentação e da incorporação no modelo proposto de algumas proxies para detecção de gerenciamento das atividades reais, não se discute, detalhadamente, a fundamentação teórica do processo de modelagem desses modelos, pois 'foge' ao escopo da pesquisa que está focada, principalmente, em relação aos accruals discricionários.

\section{a) Custos da Produção (GUNNY, 2005; ZANG, 2005; ROYCHOWDHURY, 2006)}

Os custos de produção são calculados pela soma dos custos das vendas mais a variação dos estoques. Os custos das vendas são influenciados pelas escolhas contábeis, como, por exemplo, critério de avaliação dos estoques (primeiro que entra, primeiro que sai - PEPS, último que entra, primeiro que sai - UEPS ou custo médio ponderado móvel), portanto não seriam uma boa proxy para detectar manipulação das atividades operacionais. Portanto, são utilizados os custos de produção, pois não são afetados pelas escolhas contábeis e representam as transações reais com terceiros.

Os custos das vendas são estimados por:

$$
C V_{i t}=\alpha_{0}+\alpha_{1}\left(\frac{1}{A_{t-1}}\right)+\beta_{1}\left(R_{i t}\right)+\varepsilon_{i t} \quad \text { (Equação 3.30) }
$$

em que:

$C V_{i t} \quad=$ custos das vendas da empresa $i$ no período $t$, ponderados pelos ativos totais no final do período $t-1$;

$R_{i t} \quad=$ receitas líquidas da empresa $i$ no período $t$, ponderadas pelos ativos totais no final do período $t-1$; 
$\alpha_{0}, \alpha_{1}$ e $\beta_{1}=$ coeficientes estimados da regressão pela Equação 3.30 .

Enquanto os estoques são calculados pela equação abaixo:

$$
\Delta I N V_{i t}=\alpha_{0}+\alpha_{1}\left(\frac{1}{A_{t-1}}\right)+\beta_{1}\left(\Delta R_{i t}\right)+\beta_{2}\left(\Delta R_{i t-1}\right)+\varepsilon_{i t} \quad \text { (Equação 3.31) }
$$

em que:

$\Delta I N V_{i t}=$ variação dos estoques da empresa $i$ do período $t$ - 1 para o período $t$, ponderada pelos ativos totais no final do período $t-1$;

$\Delta R_{i t}=$ variação das receitas líquidas da empresa $i$ do período $t-1$ para o período $t$, ponderada pelos ativos totais no final do período $t-1$;

$\Delta R_{i t-1}=$ variação das receitas líquidas da empresa $i$ do período $t-2$ para o período $t-1$, ponderada pelos ativos totais no final do período $t-1$;

$\alpha_{0}, \alpha_{1}, \beta_{1}$ e $\beta_{2}=$ coeficientes estimados da regressão pela Equação 3.29.

Então, os custos de produção são mensurados pela Equação 3.32, que é uma combinação das duas equações anteriores:

$$
\operatorname{Pr}_{i t}=\alpha_{0}+\alpha_{1}\left(\frac{1}{A_{t-1}}\right)+\beta_{1}\left(R_{i t}\right)+\beta_{2}\left(\Delta R_{i t}\right)+\beta_{3}\left(\Delta R_{i t-1}\right)+\varepsilon_{i t} \quad \text { (Equação 3.32) }
$$

em que:

$\operatorname{Prod}_{i t}=$ custos de produção da empresa $i$ no período $t$, ponderados pelos ativos totais no final do período $t-1$;

$R_{i t} \quad=$ receitas líquidas da empresa $i$ no período $t$, ponderadas pelos ativos totais no final do período $t-1$;

$\Delta R_{i t}=$ variação das receitas líquidas da empresa $i$ do período $t-1$ para o período $t$, ponderada pelos ativos totais no final do período $t-1$;

$\Delta R_{i t-1}=$ variação das receitas líquidas da empresa $i$ do período $t-2$ para o período $t-1$, ponderada pelos ativos totais no final do período $t-1$;

$\alpha_{0}, \alpha_{1}, \beta_{1}$ e $\beta_{2}=$ coeficientes estimados da regressão pela Equação 3.32.

Para identificar se as empresas praticaram manipulação das atividades operacionais, Roychowdhury (2006) controla a variação sistemática do fluxo de caixa, custo de produção e despesas discricionárias, através de variáveis que representam o tamanho da empresa (logaritmo do valor de mercado do patrimônio líquido (equity) no inicio do período. 
b) Gastos com pesquisa e desenvolvimento (GUNNY, 2005; ZANG, 2005)

A regressão para estimar os gastos com pesquisa e desenvolvimento é definida da seguinte forma:

$$
P \& D_{i t}=\alpha_{0}+\beta_{1}\left(P \& D_{i t-1}\right)+\beta_{2}\left(\text { Fundos }_{i t}\right)+\beta_{3}\left(\text { QTobin }_{i t}\right)+\beta_{3}\left(\text { GInvest }_{i t}\right)+\varepsilon_{i t} \quad \text { (Equação 3.33) }
$$

em que:

$P \& D_{i t} \quad=$ gastos com pesquisas e desenvolvimento da empresa $i$ no período $t$, ponderados pelos ativos totais no final do período $t-1$;

$P \& D_{i t-1}=$ gastos com pesquisas e desenvolvimento da empresa $i$ no período $t-1$, ponderados pelos ativos totais no final do período $t-1$;

Fundos $_{i t}=$ fundos de recursos internos da empresa $i$ no período $t$, ponderados pelos ativos totais no final do período $t-1$;

QTobin $_{i t}=$ índice $\mathrm{Q}$ de Tobin da empresa $i$ no período $t$;

GInvest $_{i t}=$ montante dos gastos para inversões fixas (imobilizados) da empresa $i$ no período $t$, ponderado pelos ativos totais no final do período $t-1$;

$\alpha_{0}, \beta_{1}, \beta_{2}$ e $\beta_{3}=$ coeficientes estimados da regressão pela Equação 3.33 .

Darrough e Rangan (2005) evidenciaram que a venda de ações dos insiders na oferta pública inicial (Initial Public Offering - IPO) influencia o montante de recursos alocados para as despesas de pesquisa e desenvolvimento (P\&D) pelas empresas e, assim, espera-se que os administradores reduzam, operacionalmente, P\&D para afetar os resultados reportados.

c) Despesas operacionais (GUNNY, 2005; ZANG, 2005)

Como foi descrito anteriormente, a administração pode afetar os resultados contábeis pela redução de algumas despesas com o intuito de melhorar os seus resultados contábeis, afetando o padrão dessas despesas. Na apuração dessas despesas, não são considerados os gastos com pesquisas e desenvolvimento, sendo estimados da seguinte forma:

$$
\begin{gathered}
\log \left(\frac{D O_{i t}}{D O_{i t-1}}\right)=\alpha_{0}+\beta_{1} \log \left(R_{i t}\right)+\beta_{2} \log \left(R_{i t}\right) x D R_{i t}+\beta_{3} \log \left(R_{i t-1}\right)+ \\
\beta_{4} \log \left(R_{i t-1}\right) x D R_{i t-1}+\varepsilon_{i t} \quad(\text { Equação 3.34) }
\end{gathered}
$$

em que:

$D O_{i t} \quad=$ despesas operacionais da empresa $i$ no período $t$;

$D O_{i t-1}=$ despesas operacionais da empresa $i$ no período $t-1$; 
$R_{i t} \quad=$ receitas líquidas da empresa $i$ no período $t$, ponderadas pelas receitas líquidas no período $t-1$;

$D R_{i t} \quad=$ variável dummy que indica o decréscimo das receitas líquidas da empresa $i$ no período $t$, se $R_{i t}<R_{i t-1}$, então, assume o valor ' 1 ', nos demais casos, assume valor ' 0 ';

$R_{i t-1} \quad=$ receitas líquidas da empresa $i$ no período $t-1$, ponderadas pelas receitas líquidas no período $t-2$;

$D R_{i t-1} \quad=$ variável dummy que indica o decréscimo das receitas líquidas da empresa $i$ no período $t-1$, se $R_{i t-1}<R_{i t-2}$, então, assume o valor ' 1 ', nos demais casos, assume valor ' 0 ';

$\alpha_{0}, \beta_{1}, \beta_{2}, \beta_{3}$ e $\beta_{4} \quad=$ coeficientes estimados da regressão pela Equação 3.34 .

d) Resultados com as vendas dos ativos permanentes (GUNNY, 2005; ZANG, 2005)

Gunny (2005) e Zang (2005) consideram, ainda, que podem ocorrer vendas de investimentos em empresas e de imobilizados estruturadas de forma a manipular os resultados contábeis. Assim, estabelecem uma regressão para capturar o padrão normal dessas operações:

$$
R V A P_{i t}=\alpha_{0}+\beta_{1}\left(V_{-} P P E_{i t}\right)+\beta_{2}\left(V_{-} A I_{i t}\right)+\beta_{3}\left(\Delta R_{i t}\right)+\varepsilon_{i t} \quad \text { (Equação 3.35) }
$$

em que:

$R V A P_{i t} \quad=$ resultados das vendas dos ativos permanentes da empresa $i$ no período $t$, ponderados pelos ativos totais no final do período $t-1$;

$V_{-} P P E_{, t} \quad=$ receitas com vendas do Ativo Imobilizado da empresa $i$ no final do período $t$, ponderadas pelos ativos totais no final do período $t-1$;

$V_{-} A I_{i t} \quad=$ receitas com vendas do Ativo Investimentos da empresa $i$ no final do período $t$, ponderadas pelos ativos totais no final do período $t-1$;

$\Delta R_{i t} \quad=$ variação das receitas líquidas da empresa $i$ do período $t-1$ para o período $t$, ponderada pelos ativos totais no final do período $t-1$;

$\alpha_{0}, \beta_{1}, \beta_{2}$ e $\beta_{3}=$ coeficientes estimados da regressão pela Equação 3.35.

e) Fluxo de caixa operacional (ROYCHOWDHURY, 2006)

O fluxo de caixa operacional está reportado na Demonstração do Fluxo de Caixa, sendo que seu comportamento normal é obtido pelo resíduo da seguinte equação: 


$$
C F O_{i t}=\alpha_{0}+\alpha_{1}\left(\frac{1}{A_{t-1}}\right)+\beta_{1}\left(R_{i t}\right)+\beta_{2}\left(\Delta R_{i t}\right)+\varepsilon_{i t} \quad \text { (Equação 3.36) }
$$

em que:

$C F O_{i t}=$ fluxo de caixa operacional da empresa $i$ no período $t$, ponderado pelos ativos totais no final do período $t-1$;

$R_{i t} \quad=$ receitas líquidas da empresa $i$ no período $t$, ponderadas pelos ativos totais no final do período $t-1$;

$\Delta R_{i t} \quad=$ variação das receitas líquidas da empresa $i$ do período $t-1$ para o período $t$, ponderada pelos ativos totais no final do período $t-1$;

$\alpha_{0}, \alpha_{1}, \beta_{1}$ e $\beta_{2}=$ coeficientes estimados da regressão pela Equação 3.36.

Essa proxy está pautada na relação de que as atividades de gerenciamento das atividades operacionais (como, por exemplo, descontos anormais para incentivar as vendas no final do período) afetam o padrão do fluxo de caixa operacional corrente (no caso, redução do nível de fluxo de caixa operacional). Dechow et al (2003, p.356) consideram que o aumento do fluxo de caixa pode ser uma conseqüência da manipulação das atividades reais para melhorar a desempenho da empresa.

f) Despesas discricionárias (ROYCHOWDHURY, 2006)

Roychowdhury (2006) estabelece uma regressão de busca capturar o padrão das despesas da empresas, que seria semelhante à agregação dos itens $b$ e $c$ (GUNNY, 2005; ZANG, 2005). Essas, denominadas pelo autor de 'despesas discricionárias', sendo apuradas pela a soma das despesas com publicidade, despesas com pesquisas e desenvolvimento e despesas gerais, administrativas e de vendas, e são estimadas da seguinte forma:

$$
\operatorname{DespDisc}_{i t}=\alpha_{0}+\alpha_{1}\left(\frac{1}{A_{t-1}}\right)+\beta_{1}\left(R_{i t}\right)+\varepsilon_{i t} \quad(\text { Equação 3.37) }
$$

em que:

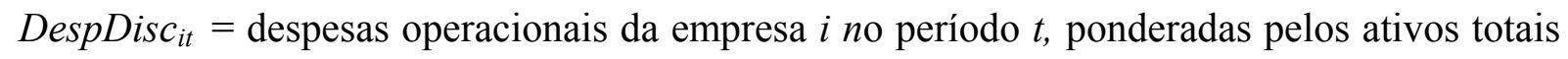
no final do período $t-1$;

$R_{i t} \quad=$ receitas líquidas da empresa $i$ no período $t$, ponderadas pelos ativos totais no final do período $t-1$;

$\alpha_{0}, \alpha_{1}$ e $\beta_{1}=$ coeficientes estimados da regressão pela Equação 3.37. 


\section{B. Considerações}

Assim como na estimação dos accruals discricionários, os modelos para capturar o gerenciamento através das atividades operacionais reais das empresas sofrem algumas críticas:

a) Os custos de produção sofrem efeitos de algumas escolhas contábeis, como, por exemplo, método de cálculo das despesas de depreciação e amortização;

b) O modelo pode falhar na identificação de gerenciamento quando as empresas mantêm altos níveis de estoques;

c) As variáveis utilizadas para controlar o ambiente econômico podem estar contaminadas pelo gerenciamento de resultados;

d) A variação dos preços em seus produtos e insumos, ao longo do tempo, pode prejudicar as inferências;

e) No contexto brasileiro, os gastos com pesquisa e desenvolvimento são reconhecidos, inicialmente, como ativos.

Em alguns aspectos, o conjunto de modelos de gerenciamento de atividades operacionais é semelhante ao modelo Jones (1991), discutido anteriormente, para detecção de accruals discricionários. Alguns modelos mantêm a variável $\left(1 / \mathrm{A}_{\mathrm{it}-1}\right)$ para evitar correlação espúria entre as variáveis explicativas e a variável dependente, porém existe o termo constante $\alpha$ da equação, o que resolve o viés da $R^{2}$ apresentado nos modelos Jones e Jones Modificado.

A suposição de que as escolhas contábeis não afetam os custos de produção é fraca, pois alguns gastos são estimativas e podendo ser influenciadas pela decisão dos administradores.

Segundo o trabalho de Roychowdhury (2006), existem evidências de que as empresas manipulam as atividades operacionais reais para evitar divulgação de perdas e erros negativos na previsão dos analistas. Cardoso e Martinez (2006), com base em uma amostra composta por companhias abertas brasileiras no período de 1998 a 2004, encontraram evidências que essas empresas efetuaram gerenciamento de resultados através das decisões operacionais.

Ewert e Wagenhofer (2005) e Cardoso e Martinez (2006) consideram que, quanto mais restritivas forem as normas contábeis, mais aumenta a possibilidade de substituição dos accruals discricionários pelo gerenciamento das atividades reais. 
3.6 Proposta do modelo de estimação dos accruals discricionários para detecção de gerenciamento de resultados

Muitos estudos apresentam abordagens alternativas para solucionar o problema de má especificação dos modelos que buscam decompor os accruals em esperados (accruals normais) e não-esperados (accruals anormais), pautados em pressupostos e em evidências de pesquisas anteriores, sendo que o mesmo processo ocorre neste trabalho.

Para tanto, na primeira parte dessa seção (3.6.1), aponta algumas premissas relevantes para a construção de modelos operacionais que têm como objetivo detectar o gerenciamento de resultados através de accruals e/ou atividades operacionais (suposições 1 a 4) e de segregar accruals discricionários dos não-discricionários (suposições 1 a 12). Na subseção seguinte (3.6.2) é especificado o modelo proposto com base nas premissas assumidas para estimar os accruals discricionários para detecção de gerenciamento de resultados através das escolhas contábeis (objeto deste trabalho).

3.6.1 Suposições utilizadas para especificação do modelo proposto para detecção de gerenciamento de resultados e para estimação dos accruals discricionários

Suposição 1: O gerenciamento de resultados pode ser efetuado através dos accruals e/ou das atividades operacionais

Como foi discutido anteriormente, existem diversas formas de manipulação das informações contábeis, de maneira que o administrador reporte o desempenho da forma desejada. Especificamente, os resultados contábeis podem ser manipulados pelos accruals e pelas atividades operacionais, portanto, pode-se descrever o resultado contábil reportado da seguinte forma:

$$
E=E^{*}+A M+R M \quad(\text { Equação 4.01) }
$$

em que:

$E \quad=$ resultado contábil reportado pela empresa no período;

$E^{*} \quad=$ resultado contábil natural da empresa no período (sem os efeitos de qualquer tipo de gerenciamento de resultados); 
$A M \quad=$ parcela do resultado contábil reportado pela empresa no período, que foi gerenciada através dos accruals (accruals management);

$R M \quad=$ parcela do resultado contábil reportado pela empresa no período, que foi gerenciada através das atividades operacionais reais (real activities manipulation).

Uma proxy para a parcela gerenciada dos resultados através das escolhas contábeis seria os accruals discricionários estimados por alguns dos modelos operacionais propostos para essa determinada finalidade.

Ewert e Wagenhofer (2005, p.1113-1115) consideram que existe a possibilidade de modelar uma interação direta entre o gerenciamento dos accruals e das atividades reais. Além disso, alertam que, no caso de ignorar os efeitos de gerenciamento das atividades reais na estimação de accruals discricionários, pode-se ter um efeito significativo na estimação dos parâmetros dos modelos.

Essa observação é consistente com a afirmação de que os resultados podem ser gerenciados pelas escolhas contábeis e/ou atividades operacionais (HEALY; WAHLEN, 1999; GIROUX, 2004) e na crítica sobre os modelos operacionais que estimam os accruals discricionários sem controlar o gerenciamento proporcionado nas atividades reais (ROYCHOWDHURY, 2006).

\section{Suposição 2: As empresas podem gerenciar os resultados contábeis com base em vários incentivos simultâneos}

Como descrito anteriormente, pode existir mais de um incentivo para que os gestores se comportem oportunisticamente, interferindo assim no processo de mensuração e evidenciação dos números contábeis.

Então, o modelo teórico proposto por McNichols e Wilson (1988) para testar as hipóteses de gerenciamento dos accruals deve conter um conjunto de variáveis particionadas (Equação 3.08), que, supostamente, capturam os fatores motivadores de manipulação, podendo ser descrita da seguinte forma:

$$
A M_{t}=\theta_{0}+\sum_{j} \theta_{1, j}\left(A M I n c_{i t, j}\right)+\sum_{k=1}^{k} \gamma_{k} X_{k t}+\varepsilon_{i t} \quad(\text { Equação 4.02) }
$$

em que:

$A M_{t}=$ manipulação dos resultados contábeis através dos accruals por parte da empresa no período $t$; 
AMInc $_{\text {it }}=$ conjunto de variáveis particionadas que capturam os incentivos $j$ supostos para o gerenciamento dos accruals pela empresa $i$ no período $t$;

$X_{i t} \quad=$ outros fatores que influenciam o comportamento dos accruals discricionários da empresa $i$ no período $t$;

$\varepsilon_{i, t}=$ fatores aleatórios não relacionados à hipótese específica de gerenciamento de resultados da empresa $i$ no período $t$;

A empresa pode ter mais de um incentivo em um mesmo período de tempo (incentivos simultâneos), então a variável $A M I n c$ representa o conjunto de supostos incentivos que afetam o comportamento oportunístico da empresa. Os coeficientes $\theta_{1, j}$ são utilizados para extrair inferências sobre os incentivos para o gerenciamento de resultados diante da hipótese testada. Espera-se que, no caso de manipulação dos accruals ligados ao incentivo testado, o coeficiente $\theta j$ correspondente seja, significativamente, diferente de zero.

Consistentemente com o exposto por McNichols e Wilson (1988), o modelo proposto deve controlar outros fatores institucionais e organizacionais que afetem significativamente o comportamento dos accruals discricionários.

Além disso, os accruals totais podem ser correlacionados a fatores do ambiente econômico, como o crescimento natural de uma empresa ou da economia, bem como às mudanças das políticas econômicas, principalmente, a monetária e a cambial. ${ }^{53}$

Conseqüentemente, a falta de controle desses fatores pode trazer problemas nas pesquisas empíricas, como a má especificação do modelo e erros na mensuração das variáveis (GREENE, 2003; DAVIDSON; MACKINNON, 2003), além da busca do pesquisador por explicações alternativas que suportem as evidências contrárias àquelas esperadas.

Burgstahler et al (2006, p.998) sugerem alguns fatores potenciais que poderiam auxiliar na estimação dos accruals como: o crescimento da firma, a lucratividade, a extensão do ciclo operacional, a qualidade da auditoria, o tempo de vida da empresa e a concentração da propriedade da empresa.

A escolha de alguma variável de controle na estimação dos accruals depende fortemente da hipótese testada pelo pesquisador.

\footnotetext{
${ }^{53}$ Santos e Paulo (2006) apresentam evidências de gerenciamento de resultados através do diferimento das perdas cambiais nos anos de 1999 e 2001.
} 
Igualmente, podem existir incentivos múltiplos associados ao gerenciamento de resultados através das atividades operacionais, que são especificados da seguinte forma:

$$
R M_{t}=\theta_{0}+\sum_{j} \theta_{1, j}\left(R M I n c_{i t, j}\right)+\sum_{k=1}^{k} \gamma_{k} X_{k t}+\varepsilon_{i t} \quad \text { (Equação 4.03) }
$$

em que:

$R M_{t} \quad=$ manipulação dos resultados contábeis através das atividades operacionais por parte da empresa no período $t$;

$R M I n c_{i t}=$ conjunto de variáveis particionadas que capturam os incentivos $j$ supostos para o gerenciamento das atividades operacionais pela empresa $i$ no período $t$;

$X_{i t} \quad=$ outros fatores que influenciam o comportamento dos accruals discricionários da empresa $i$ no período $t$;

$\varepsilon_{i, t}=$ fatores aleatórios não relacionados à hipótese específica de gerenciamento de resultados da empresa $i$ no período $t$.

\section{Suposição 3: Existem custos associados ao gerenciamento dos resultados contábeis}

Outro aspecto relevante a ser observado é de que os administradores se utilizam das práticas de gerenciamento de resultados se houver incentivos e oportunidades. Os incentivos estão fortemente influenciados pelos beneficios do uso das práticas discricionárias, como, por exemplo, se os benefícios marginais são reduzidos, os administradores racionais não efetuarão o gerenciamento dos números contábeis. As oportunidades são influenciadas pelos aspectos institucionais, como, por exemplo, limites regulatórios, nível de monitoramento pelos diversos agentes econômicos (governamentais ou não) ou a existência de maiores ou menores chances dos usuários da informação contábil detectar as práticas de gerenciamento de resultados. Porém, os incentivos e oportunidades de manipulação das informações contábeis são limitados pelos custos associados à prática de gerenciamento.

Os modelos para detecção de gerenciamento de resultado, no seu desenvolvimento analítico, não apresentam considerações sobre os custos de manipulação das informações contábeis ${ }^{54}$. A observação desse aspecto pode ampliar e melhorar as hipóteses levantadas sobre gerenciamento de resultados e auxiliar na compreensão do trade-off existente entre custos e benefícios associados às manipulações contábeis.

\footnotetext{
${ }^{54}$ Exceto os trabalhos de Ewert e Wagenhofer (2005) e Zang (2005).
} 
Por exemplo, no contexto brasileiro podem-se incluir os custos tributários associados ao gerenciamento dos resultados contábeis, tanto pelos accruals, quanto pelas atividades empresariais, devido à forte relação da carga tributária ao faturamento total da empresa.

Para testar as hipóteses de gerenciamento dos accruals, os modelos descritos pelas Equações 4.02 e 4.03 devem ser ampliados, pois o conjunto de variáveis particionadas que, supostamente, capturam os fatores motivadores de manipulação, não é ortogonal com os custos associados a tal prática oportunística.

Portanto, o modelo para a detecção de gerenciamento de resultados através dos accruals é descrito da seguinte forma:

$$
A M_{t}=\theta_{0}+\sum_{j} \theta_{1, j}\left(\text { AMInc }_{i t, j}\right)+\sum_{k} \theta_{2, k}\left(\text { AMCustos }_{i t, k}\right)+\sum_{k=1}^{k} \gamma_{k} X_{k t}+\varepsilon_{i t} \quad \text { (Equação 4.04) }
$$

em que:

$A M_{t} \quad=$ manipulação dos resultados contábeis através dos accruals por parte da empresa no período $t$;

$A_{\text {MInc }}$ it = conjunto de variáveis particionadas que capturam os incentivos $j$ supostos para o gerenciamento dos accruals pela empresa $i$ no período $t$;

AMCustos $_{i t}=$ conjunto dos custos $k$ associados à prática de gerenciamento dos accruals pela empresa $i$ no período $t$;

$X_{i t} \quad=$ outros fatores que influenciam o comportamento dos accruals discricionários da empresa $i$ no período $t$;

$\varepsilon_{i, t}=$ fatores aleatórios não relacionados à hipótese específica de gerenciamento de resultados da empresa $i$ no período $t$;

Já o modelo para a detecção de gerenciamento de resultados através das atividades operacionais é descrito da seguinte forma:.

$$
R M_{t}=\theta_{0}+\sum_{j} \theta_{1, j}\left(R M I n c_{i t, j}\right)+\sum_{k} \theta_{2, k}\left(R M \text { Custos }_{i t, k}\right)+\sum_{k=1}^{k} \gamma_{k} X_{k t}+\varepsilon_{i t} \quad \text { (Equação 4.05) }
$$

em que:

$R M_{t}=$ manipulação dos resultados contábeis através das atividades operacionais por parte da empresa no período $t$;

$R_{\text {MInc }}$ it = conjunto de variáveis particionadas que capturam os incentivos $j$ supostos para o gerenciamento das atividades operacionais pela empresa $i$ no período $t$;

RMCustos $_{i t}=$ conjunto dos custos $k$ associados a prática de gerenciamento dos atividades operacionais pela empresa $i$ no período $t$; 
$X_{i t} \quad=$ outros fatores que influenciam o comportamento dos accruals discricionários da empresa $i$ no período $t$;

$\varepsilon_{i, t} \quad=$ fatores aleatórios não relacionados à hipótese específica de gerenciamento de resultados da empresa $i$ no período $t$.

Os coeficientes $\theta_{2, k}$ (nas Equações 4.04 e 4.05) são utilizados para extrair inferências sobre os custos associados ao gerenciamento de resultados e se o custo testado for, estatisticamente relevante na escolha pela manipulação ou não dos números contábeis, o seu coeficiente seja diferente de zero $\left(\theta_{2, k} \neq 0\right)$.

Zang (2005) sugere como proxies de custos (restrições) associados ao gerenciamento dos resultados através dos accruals ou das atividades operacionais das empresas, algumas variáveis como reputação da auditoria, nível de escrutínio pelos diversos agentes econômicos, reversão dos accruals nos períodos seguintes, custo da superprodução, market share, nível de competição, entre outros indicadores.

\section{Suposição 4: O comportamento anormal dos accruals é considerado como uma proxy agregada do gerenciamento de resultados através das escolhas contábeis}

Para o desenvolvimento de um modelo adequado para detecção de gerenciamento de resultados, deve-se ter em mente que nem todos os accruals são efetivamente tentativas de manipulação das informações contábeis. ${ }^{55}$ Como descrito na seção 3.2, os accruals totais são decompostos em não-gerenciados (não-discricionários) e gerenciados (discricionários), e considerando que o accrual discricionário é proxy para o gerenciamento de resultados através das escolhas contábeis, então, têm-se:

$$
D A_{t t}=A M_{t} \quad(\text { Equação 4.06) }
$$

Em que:

$D A_{t} \quad=$ accruals discricionários da empresa no período $t$;

\footnotetext{
${ }^{55}$ Nem mesmo, os accruals discricionários mensurados pelos modelos econométricos podem ser considerados, efetivamente, como práticas de manipulação, porque existe a possibilidade da perspectiva de eficiência informacional, onde os accruals anormais carregam informações relevantes sobre o desempenho econômico da firma. Entretanto, os modelos propostos de estimação dos accruals para detecção de gerenciamento de resultados podem ser utilizados para analisar as hipóteses levantadas sobre a perspectiva da eficiência, pois, praticamente, os pressupostos assumidos sobre os comportamento dos accruals serão semelhantes.
} 
$A M_{t} \quad=$ manipulação dos resultados contábeis através dos accruals por parte da empresa no período $t$;

Substituindo a variável $A M_{t}$ pela sua proxy $D A_{t}$, o modelo para a detecção de gerenciamento de resultados através dos accruals, é descrito pela Equação 4.07:

$$
D A_{t}=\theta_{0}+\sum_{j} \theta_{1, j}\left(\text { AMInc }_{i t, j}\right)+\sum_{k} \theta_{2, k}\left(\text { AMCustos }_{i t, k}\right)+\sum_{k=1}^{k} \gamma_{k} X_{k t}+\varepsilon_{i t} \quad \text { (Equação 4.07) }
$$

$D A_{t} \quad=$ accruals discricionários da empresa no período $t ;$

$A M I n c_{i t}=$ conjunto de variáveis particionadas que capturam os incentivos $j$ supostos para 0 gerenciamento dos accruals pela empresa $i$ no período $t$;

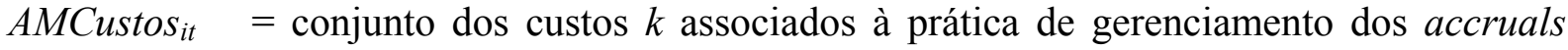
pela empresa $i$ no período $t$;

$X_{i t} \quad=$ outros fatores que influenciam o comportamento dos accruals discricionários da empresa $i$ no período $t$;

$\varepsilon_{i, t}=$ fatores aleatórios não relacionados à hipótese específica de gerenciamento de resultados da empresa $i$ no período $t$;

Os accruals discrionários podem ser estimados por alguns dos modelos operacionais para a estimação dos accruals não-discricionários e discrionários apresentados na seção 3.4 ou pelo modelo proposto neste trabalho (seção 3.6.2).

\section{Suposição 5: O modelo captura somente os accruals discricionários relacionados aos componentes de curto prazo}

Apesar de McNichols (2002) alertar sobre as limitações dos modelos operacionais que avaliam somente as transações e eventos que afetam os elementos patrimonias de curto prazo, o modelo proposto, neste trabalho, assim como todos os demais modelos nessa linha de pesquisa, mensura somente os accruals não-discricionários e discricionários de curto prazo. Essa suposição, como exposto anteriormente, é baseada no fato de que os accruals devem ser revertidos no período subseqüente, o que facilita a especificação de modelos mais parcimoniosos para o estudo e segregação dos componentes dos accruals, além de que Graham et al (2005) entrevistaram mais de 400 executivos de empresas norte-americanas e identificaram que a prática oportunística está mais voltada aos incentivos de curto prazo (78\% dos entrevistados). 
Portanto, a partir dessa suposição, este trabalho preocupa-se com a mensuração dos accruals do capital circulante. Os accruals totais do capital circulante podem ser estimados pela abordagem do Balanço Patrimonial ou da Demonstração do Fluxo de Caixa, conforme descrito na seção 3.2. A escolha por uma das duas abordagens depende, principalmente, da disponibilidade dos dados e do erro de mensuração das variáveis.

\section{Suposição 6: O lucro obrigatoriamente transita pelo caixa da empresa}

Conforme demonstrado na seção 4.1, os resultados contábeis representam fluxos de caixa nos períodos passado, presente ou futuro, podendo ser representados por (DECHOW; DICHEV, 2002):

$$
E_{t}=C F_{t-1}^{t}+C F_{t}^{t}+C F_{t+1}^{t}+\varepsilon_{t+1}^{t}-\varepsilon_{t}^{t-1} \quad(\text { Equação 1.03) }
$$

em que:

$E_{t} \quad=$ resultado contábil da empresa no período $t$;

$C F_{t-1}^{t} \quad=$ recebimentos e pagamentos de caixa no período $t-1$, mas reconhecidos no resultado contábil em $t$ (reversão dos accruals anteriores);

$C F_{t}^{t} \quad=$ recebimentos e pagamentos de caixa no período $t$ referentes aos valores reconhecidos (accrued) no resultado do próprio período $t$;

$C F_{t+1}^{t} \quad=$ recebimentos e pagamentos de caixa no período $t+1$, mas reconhecidos no resultado contábil em $t$ (novos accruals);

$\varepsilon_{t+1}^{t}=\quad$ erro de estimativa nos accruals no período $t$, referentes aos fluxos de caixa do período $t+1$;

$\varepsilon_{t}^{t-1}=\quad$ erro de estimativa nos accruals no período $t-1$, referentes aos fluxos de caixa do período $t$.

A suposição, aqui descrita, evidencia que qualquer accrual que não for realizado, monetariamente, pode ser considerado como erro de mensuração não intencional ou componente manipulado dos resultados contábeis. Cabe ressaltar que, essa suposição é limitada quando ocorrer mutações patrimoniais (exceto as provenientes dos acionistas) que não transitam pelo resultado do período, por exemplo, a reavaliação de ativos. Portanto, o modelo é baseado no conceito de Clean Surplus Relation . 


\section{Suposição 7: O processo de mensuração dos accruals é influenciado pelas atividades operacionais normais da empresa}

Os accruals têm sua origem no descolamento da realização econômica das transações e suas correspondentes realizações financeiras. Atividades operacionais como compras de insumos, vendas de produtos, contratação e utilização de pessoal, propaganda e publicidade, gestão administrativa, captação de capital de giro, etc., são algumas das maiores fontes de geração de accruals de curto prazo.

Então, esses itens, normalmente, são escolhidos como variáveis explicativas dos accruals totais. Entretanto, a falta de controle de alguns desses fatores, que seja relevante, pode trazer problemas nas pesquisas empíricas, como má especificação do modelo e erros na mensuração das variáveis (GREENE, 2003; DAVIDSON; MACKINNON, 2003).

Neste trabalho, para fins de descrição do modelo operacional proposto, são escolhidas as seguintes variáveis explicativas:

a) receitas das vendas líquidas no período $t\left(R_{t}\right)$;

b) custos e despesas operacionais no período $t\left(C D_{t}\right)$, excetuando-se as despesas financeiras e despesas com depreciação, exaustão e amortização;

c) ativo imobilizado no final do período $t\left(A I_{t}\right)$

d) ativo diferido no final do período $t\left(A D_{t}\right)$

Espera-se que as duas primeiras variáveis sejam relevantes, pois grande parcela dos accruals no capital circulante é originada desses itens e são utilizados em modelos anteriores. Entretanto, deve-se verificar se essas variáveis, realmente, não possuem forte correlação entre elas, o que acarretaria problema de multicolineariedade. A inclusão separada de uma variável para o ativo imobilizado e outra para o ativo diferido deve-se ao fato de que, normalmente, esses itens teoricamente não têm comportamentos similares. Então, tem-se:

$$
T A_{t}=f\left(R_{t} ; C D_{t} ; A I_{t} ; A D_{t} ; O_{t}\right) \quad(\text { Equação } 4.08)
$$

em que:

$T A_{t} \quad=$ accruals totais da empresa no período $t$

$R_{t} \quad=$ receitas das vendas líquidas da empresa no período $t$;

$C D_{t} \quad=$ custos e despesas operacionais da empresa no período $t$, excetuando-se as despesas financeiras e despesas com depreciação, exaustão e amortização;

$A I_{t} \quad=$ ativo imobilizado da empresa no final do período $t$

$A D_{t} \quad=$ ativo diferido no final da empresa no final do período $t$; 
$O_{t} \quad=$ outros fatores relevantes que explicam o comportamento dos accruals totais..$^{56}$

Pode-se esperar que, em alguns setores das atividades econômicas, a variável $A D_{t}$ tenha maior significância do que em outros ramos.

\section{Suposição 8: Existe uma correlação negativa entre o fluxo de caixa operacional e os accruals}

Conforme discutido anteriormente, o resultado é conseqüência dos fluxos de caixa e accruals, existindo uma correlação negativa significativa entre esses dois elementos. Então uma especificação do modelo para estimação de accruals totais deve controlar o montante do fluxo de caixa no período, para minimizar a probabilidade da regressão calcular coeficientes enviesados e/ou inconsistentes e aumentar o poder preditivo do modelo. Então, tem se:

$$
T A_{t}=f\left(F C O_{t} ; O_{t}\right) \quad(\text { Equação 4.09) }
$$

em que:

$T A_{t} \quad=$ accruals totais da empresa no período $t$

$\mathrm{FCO}_{t} \quad=$ fluxo de caixa operacional da empresa no período $t$;

$O_{t} \quad=$ outros fatores relevantes que explicam o comportamento dos accruals totais.

Considerando que os modelos anteriores têm problemas de especificação na ocorrência de desempenho extremo do fluxo de caixa (DECHOW et at, 1995; PEASNELL et al, 2000; PAE, 2005), espera-se que a inclusão da variável minimize esse problema e, conseqüentemente, melhore o poder preditivo do modelo.

\section{Suposição 9: $O$ desempenho dos resultados afeta o comportamento dos accruals}

Conforme observado anteriormente, em vários estudos empíricos (DECHOW et at, 1995; PEASNELL et al, 2000; PAE, 2005) verifica-se que os incentivos para gerenciamento de resultados e o comportamento dos accruals estão relacionados ao desempenho do resultado. Dechow et al (1995, p.209) afirmam que, usando os modelos avaliados no seu estudo, o pesquisador detectará baixos accruals discricionários quando os resultados forem baixos, e altos accruals discricionários quando forem resultados forem altos, se têm altas acumulações

\footnotetext{
${ }^{56}$ Os outros fatores relavantes são apresentados nas demais suposições.
} 
discricionárias, mesmo se a causa do gerenciamento de resultados não for o incentivo investigado pelo pesquisador. A alta rejeição da hipótese nula (não gerenciamento) é causada pelo fato de que as empresas-ano com baixo resultado tendem a ter baixo montante de accruals totais, e todos os modelos atribuem esse comportamento aos accruals discricionários. Por fim, os autores (1995, p.209) sugerem que, ao avaliar os incentivos para o gerenciamento de resultados, "o pesquisador deve garantir que os resultados não são induzidos pela existência de variáveis omitidas correlacionadas a desempenho da empresa." ${ }^{.7}$ Pode-se considerar, então, que, se não for controlada essa relação, os resíduos da regressão terão comportamento heteroscedástico, $E\left(u_{i}^{2} \mid x_{i}\right) \neq \sigma^{2}$, fazendo que os estimadores lineares do MQO não sejam eficientes.

Portanto, para uma melhor especificação do modelo de estimação dos accruals deve-se utilizar o resultado do período como uma variável explicativa:

$$
T A_{t}=f\left(E_{t} ; O_{t}\right) \quad(\text { Equação 4.10) }
$$

em que:

$T A_{t} \quad=$ accruals totais da empresa no período $t ;$

$E_{t} \quad=$ resultado contábil da empresa no período $t$;

$O_{t} \quad=$ outros fatores relevantes que explicam o comportamento dos accruals totais.

Entretanto, espera-se que o comportamento dos accruals totais seja não-linear em relação aos resultados contábeis, pois em períodos em que a empresa tenha um grande lucro contábil, ela prefira suavizar tais resultados, necessitando de um volume de accruals discricionários negativos também elevados, mas não proporcional, pois existem limites impostos para o gerenciamento de resultados pelas normas e práticas contábeis.

Por outro lado, em períodos em que o resultado real da empresa esteja um pouco aquém das metas desejadas, diante de certos incentivos, espera-se que o administrador manipule um volume necessário de accruals (discricionários) positivos de forma que consiga reportar os resultados almejados para a firma. Porém, em outros casos, empresa com um grande prejuízo, o administrador prefira não melhorar os resultados com accruals positivos, ou até mesmo, queira piorar, com accruals negativos, o resultado real naquele período, objetivando apresentar melhores desempenhos nos períodos subseqüentes (Taking a bath).

\footnotetext{
57 “...] the researcher should ensure that the results are not induced by omitted variables correlated with earnings performance."
} 
Outro ponto interessante, mesmo no caso de empresas com resultados reais próximos ao ponto de referência podem ter comportamentos díspares. Devido à presença do conservadorismo nos números contábeis, há uma tendência de maior persistência dos ganhos do que das perdas. Portanto, os accruals têm comportamento assimétrico, pois as perdas são totalmente reconhecidas, ao passo que o mesmo não ocorre com os ganhos. Dessa forma, o período de competência tende a apresentar menor lucro ou que os accruals positivos cumulativos sejam menores do que a realidade econômica.

Para ajustar a especificação anterior, são acrescentadas outras variáveis ao modelo: (1) a variável $E_{t}^{2}$ para capturar o comportamento não-linear para o resultado contábil; (2) as variáveis $\Delta E_{t-1}, D \Delta E_{t-1}$ e uma variável de interação entre elas para capturar o comportamento assimétrico derivado do conservadorismo. Assim, com base na relação descrita na Equação 4.10 e as observações sobre a relação não-linear entre os resultados e os accruals, e o nível de conservadorismo, tem-se que:

$$
T A_{t}=f\left[E_{t} ; E_{t}^{2} ; \Delta E_{t-1} ; D \Delta E_{t-1} ; \Delta E_{t-1} * D \Delta E_{t-1} ; O_{t}\right] \quad(\text { Equação 4.11) }
$$

em que:

$T A_{t} \quad=$ accruals totais da empresa no período $t$

$E_{t} \quad=$ resultado contábil da empresa no período $t ;$

$\Delta E_{t-1} \quad=$ variação no lucro líquido contábil da empresa do ano $t-2$ para o ano $t-1$;

$D \Delta E_{i t-1} \quad=$ variável dummy para indicar se existe variação negativa no lucro líquido contábil da empresa do ano $t-2$ para o ano $t$ - 1 , assumindo valor 1 se $\Delta N I_{i t-1}<0$, e 0 nos demais casos;

$O_{t} \quad=$ outros fatores relevantes que explicam o comportamento dos accruals totais.

A inclusão das variáveis $\Delta E_{t-1}, D \Delta E_{t-1}$ e uma variável de interação para avaliar a influência do conservadorismo sobre o comportamento dos accruals é consistente com a metodologia utilizada por Ball e Shivakumar (2005).

\section{Suposição 10: Os accruals são componentes transitórios do resultado contábil}

Os accruals são, freqüentemente, baseados em pressupostos e estimativas que, se incorretos, devem ser corrigidos nos futuros accruals, conseqüentemente, afetam lucros (Dechow; Dichev, 2002, p.36). Devido ao reconhecimento oportuno, os accruals passam a ser um componente transitório do resultado e tendem a ser revertidos nos períodos subseqüentes. 
A reversão natural dos accruals discricionários reduz a capacidade dos administradores em utilizar práticas e/ou operações oportunísticas semelhantes nos períodos subseqüentes, e que Zang (2005, p.18-19) emprega como uma proxy de custos (restrição) para o gerenciamento de accruals. Dechow (1994) observa que parte da variação nos resultados do período analisado é esperado pela reversão natural dos accruals de períodos anteriores.

Então, tem se:

$$
T A_{t}=f\left(T A_{t-1} ; O_{t}\right) \quad(\text { Equação 4.12) }
$$

em que:

$T A_{t} \quad=$ accruals totais da empresa no período $t$;

$T A_{t-1}=$ accruals totais da empresa no período $t-1$;

$O_{t} \quad=$ outros fatores relevantes que explicam o comportamento dos accruals totais.

A utilização dos accruals totais defasados em somente um período $(t-l)$ deve-se à necessidade de se manter a consistência lógica com as suposições 5 e 6 assumidas anteriormente.

\section{Suposição 11: A manipulação das atividades operacionais pode afetar os accruals no processo de mensuração contábil}

Apesar de Ewert e Wagenhofer (2005) e Roychowdhury (2006) estabelecerem que a manipulação das atividades reais afeta, parcialmente, os accruals, as pesquisas correntes não corrigem a relação existente entre elas na estimação dos accruals não-discricionários. Se a manipulação dos accruals tiver multicolinearidade perfeita com os efeitos econômicos das mudanças anormais das atividades operacionais, o gerenciamento de resultados de ambas as formas poderia ser capturado pelas variáveis dos modelos propostos anteriormente. Porém, não existe uma fundamentação teórica que sustente o pressuposto de que os accruals se alterem proporcionalmente à mudança das atividades operacionais. Então, assume-se neste trabalho que, os accruals são afetados pela manipulação das atividades operacionais e que não existe uma correlação perfeita entre elas.

Assim, para corrigir a influência do gerenciamento das atividades reais sobre o comportamento dos accruals assume-se que:

a) existe um trade-off entre a manipulação dos accruals (AM) e a manipulação das atividades operacionais (RM); 
b) a decisão de manipulação das atividades operacionais (RM) precede a manipulação dos accruals (AM).

Diante do pressuposto de manipulação seqüencial dos resultados pode-se, primeiramente, calcular os comportamentos anormais das atividades operacionais da empresa, e acrescentálas como variáveis de controle para a estimação dos accruals. Neste trabalho, foram escolhidas como proxies para o gerenciamento das atividades operacionais da empresa: custos de produção, despesas operacionais e fluxo de caixa operacional.

O padrão dos custos de produção tem como propósito capturar o comportamento anormal dos estoques, devido ao aumento do volume de produção para redução dos custos unitários através da economia de escala; enquanto as despesas operacionais anormais podem indicar presença de decisões discricionárias nas atividades operacionais normais, como corte de alguns gastos operacionais para que se possam atingir certos resultados. Cardoso e Martinez (2006) evidenciaram que esses dois indicadores de gerenciamento mediante decisões operacionais foram correlacionados significativamente com os accruals anormais e comprova a existência de trade-off entre a manipulação dos accruals e das atividades operacionais, como indicado no item ' $a$ ' anterior.

O comportamento anormal do fluxo de caixa operacional busca captar manipulação das vendas realizadas, pois essa decisão de gerenciamento afeta diretamente o fluxo de caixa da empresa. Além disso, deve-se considerar que o comportamento anormal do fluxo de caixa tem correlação negativa com os accruals discricionários.

Então, têm-se:

$$
T A_{t}=f\left(a b_{-} \operatorname{Pr} O d_{t} ; a b_{-} D O_{t} ; a b_{-} C F O_{t} ; O_{t}\right) \quad(\text { Equação 4.13) }
$$

em que:

$T A_{t}=$ accruals totais da empresa no período $t$;

$A b_{-} \operatorname{Prod}_{i t}=$ comportamento anormal dos custos de produção da empresa no período $t$;

$A b_{-} D O_{i t} \quad=$ comportamento anormal das despesas operacionais da empresa no período $t$;

$A b_{-} C F O_{i t}=$ comportamento anormal do fluxo de caixa operacionais da empresa no período $t$

$O_{t} \quad=$ outros fatores relevantes que explicam o comportamento dos accruals totais. 
O comportamento anormal dos custos de produção, das despesas operacionais e do fluxo de caixa operacional, é calculado conforme as Equações 3.32, 3.34 e 3.36 apresentadas na seção 3.5 .

\section{Suposição 12: A estimação deve ser efetuada separadamente por setor econômico}

Consistente com trabalhos anteriores (PEASNELL et al, 2000; ZANG, 2005), o modelo proposto busca controlar características peculiares de cada setor econômico com o intuito de estimar accruals discricionários mais consistentes. O objetivo é reduzir a probabilidade das estimativas de os accruals anormais serem contaminados pelos efeitos setoriais, minimizando a influência de fatos particulares de gerenciamento de resultados não observáveis sobre as estimativas dos parâmetros dos accruals normais.

Neste trabalho, a classificação setorial utilizada foi a descrita no banco de dados Economática $^{58}$.

\section{Síntese das suposições}

As suposições assumidas para especificação do modelo, bem como a justificativa para sua incorporação e as limitações da aplicação, são apresentadas resumidamente no Quadro 02 a seguir:

Quadro 02 - Suposições assumidas no modelo proposto

\begin{tabular}{|c|c|}
\hline $\mathbf{N}^{\mathbf{0}}$ & Suposição \\
\hline $\mathbf{0 1}$ & $\begin{array}{c}\text { Descrição: O gerenciamento de resultados pode ser efetuado através dos accruals e/ou das atividades } \\
\text { operacionais. } \\
\text { Justificativa: Como apresentado anterioremente, alguns trabalhos (GUNNY, 2005 ROYCHOEDHURY, } \\
\text { 2006) evidenciam que as escolhas contábeis (accruals) e as atividades operacionais são utilizadas } \\
\text { para alterar, oportunisticamente, os resultados contábeis. } \\
\text { Limitações: O modelo não incorpora outras formas de manipulação das informações contábeis, como a } \\
\text { manipulação classificatória dos elementos das demonstrações contábeis. }\end{array}$ \\
\hline $\begin{array}{l}\text { Descrição: As empresas podem gerenciar os resultados contábeis com base em vários incentivos } \\
\text { simultâneos. }\end{array}$ \\
$\begin{array}{c}\text { Limificativa: Existem diversos incentivos para o gerenciamento de resultados que concorrem ao mesmo } \\
\text { momento, e que se não forem observados nas pesquisas podem conduzir a inferências inadequadas } \\
\text { sempre é evidente e de fácil percepção.pelo pesquisador. }\end{array}$ \\
\hline
\end{tabular}

\footnotetext{
${ }^{58}$ O programa Economática é utilizado para fazer análises econômico-financeiras de empresas. Para maiores informações sobre o produto visite a home page http://www.economatica.com.br
} 
Quadro 02 - Suposições assumidas no modelo proposto (continuação)

\begin{tabular}{|c|c|}
\hline $\mathbf{N}^{\mathbf{0}}$ & Suposição \\
\hline 03 & $\begin{array}{l}\text { Descrição: Existem custos associados ao gerenciamento dos resultados contábeis. } \\
\text { Justificativa: Os incentivos e oportunidades para o comportamento discricionário está relacionado } \\
\text { diretamente à relação custo-benefício, sendo que os custos restringem a manipulação das informações } \\
\text { contábeis. } \\
\text { Limitações: Identificação de proxies para captar os custos associados à prática oportunística, e que } \\
\text { estejam respaldadas em fundamentos teóricos adequados. }\end{array}$ \\
\hline 04 & $\begin{array}{l}\text { Descrição: O comportamento anormal dos accruals é considerado como uma proxy agregada do } \\
\text { gerenciamento de resultados através das escolhas contábeis. } \\
\text { Justificativa: Os accruals não-esperados (accruals discricionários) são uma aproximação de uma medida } \\
\text { da anormalidade dos resultados contábeis que, supostamente, se originam dos incentivos para } \\
\text { manipulação dos resultados contábeis. } \\
\text { Limitações: A variável que mensura o gerenciamento de resultados (accruals discricionários) não é uma } \\
\text { variável observável. }\end{array}$ \\
\hline 05 & $\begin{array}{l}\text { Descrição: O modelo captura somente os accruals discricionários que estão relacionados aos componentes } \\
\text { de curto prazo. } \\
\text { Justificativa: Facilidade de especificação do modelo e evidências de que o gerenciamento de resultados } \\
\text { está relacionado aos incentivos de curto prazo. } \\
\text { Limitações: Os resultados contábeis podem ser afetados oportunisticamente por accruals de longo prazo. }\end{array}$ \\
\hline 06 & $\begin{array}{l}\text { Descrição: O lucro obrigatoriamente transita pelo caixa da empresa. } \\
\text { Justificativa: Utiliza o conceito de Clear Surplus Relation. } \\
\text { Limitações: O modelo pode não apresentar evidências adequadas sobre as hipóteses apresentadas quando } \\
\text { o conceito Clear Surplus Relation não for observado. }\end{array}$ \\
\hline 07 & $\begin{array}{l}\text { Descrição: O processo de mensuração dos accruals é influenciado pelas atividades operacionais normais } \\
\text { da empresa. } \\
\text { Justificativa: Os accruals têm como uma das principais origens a realidade econômica das atividades } \\
\text { operacionais da empresa. } \\
\text { Limitações: As variáveis utilizadas para capturar a influência das atividades operacionais podem estar } \\
\text { contaminadas pelo gerenciamento de resultados. }\end{array}$ \\
\hline 08 & $\begin{array}{l}\text { Descrição: Existe uma correlação negativa entre o fluxo de caixa operacional e os accruals. } \\
\text { Justificativa: Devido às evidências da má especificação dos modelos quando ocorre desempenho extremo } \\
\text { de fluxos de caixa e pela existência de correlação negativa entre ela e os accruals do período. } \\
\text { Limitações: Mensuração inadequada da variável 'fluxo de caixa operacional', pois nem sempre é uma } \\
\text { variável observável. }\end{array}$ \\
\hline 09 & $\begin{array}{l}\text { Descrição: O desempenho dos resultados afeta o comportamento dos accruals. } \\
\text { Justificativa: Devido às evidências da má especificação dos modelos quando ocorre desempenho extremo } \\
\text { de resultados. } \\
\text { Limitações: A variável 'resultado contábil' pode estar contaminada pelo gerenciamento de resultados. }\end{array}$ \\
\hline 10 & $\begin{array}{l}\text { Descrição: Os accruals são componentes transitórios do resultado contábil. } \\
\text { Justificativa: Devido ao processo de reversão natural dos accruals totais. } \\
\text { Limitações: A reversão dos accruals não necessariamente deve ocorrer no período subseqüente. }\end{array}$ \\
\hline 11 & $\begin{array}{l}\text { Descrição: A manipulação das atividades operacionais pode afetar os accruals no processo de mensuração } \\
\text { contábil. } \\
\text { Justificativa: Qualquer modificação anormal nas atividades operacionais da empresa podem conduzir a } \\
\text { uma interferência na estimação do componente gerenciado (anormal) dos accruals. } \\
\text { Limitações: Dificuldade em capturar o gerenciamento de resultados através das atividades operacionais. }\end{array}$ \\
\hline 12 & $\begin{array}{l}\text { Descrição: A estimação deve ser efetuada separadamente por setor econômico. } \\
\text { Justificativa: Considera-se que os fatores econômicos que afetam diferentemente o comportamento dos } \\
\text { accruals nas empresas possam ser semelhantes dentro um mesmo setor econômico. } \\
\text { Limitações: Não considera estratégias diferentes entre as empresas do mesmo setor econômico. }\end{array}$ \\
\hline
\end{tabular}




\subsubsection{Modelo operacional proposto para mensuração dos accruals discricionários}

Com base nas suposições anteriores de que o montante dos accruals discricionários é proxy para gerenciamento dos resultados contábeis (suposição 4) e no controle dos efeitos do gerenciamento das atividades operacionais sobre a estimação dos accruals (suposição 11), tem-se o seguinte modelo de mensuração dos accruals:

$$
\begin{gathered}
T A_{t}=f\left(R_{t} ; C D_{t} ; A I_{1} ; A D_{t} ; F C O_{t} ; E_{t} ; E_{t}^{2} ; \Delta E_{t-1} ; D \Delta E_{t-1} ; \Delta E_{t-1} * D \Delta E_{t-1} ;\right. \\
\left.T A_{t-1} ; a b_{-} \operatorname{Pr} o d_{t} ; a b_{-} D O_{t} ; a b_{-} C F O_{t} ; O_{t}\right)
\end{gathered}
$$

Então, o modelo para pesquisa empírica é descrito como:

$$
\begin{aligned}
T A_{i t}=\alpha+ & \beta_{1} R_{i t}+\beta_{2} C D_{i t}+\beta_{3} A I_{i t}+\beta_{4} A D_{i t}+\lambda_{1} F C O_{i t}+ \\
& \lambda_{2} E_{i t}+\lambda_{3} E_{i t}^{2} ;+\lambda_{4} \Delta E_{i t-1}+\lambda_{5} D \Delta E_{i t-1}+\lambda_{.6} \Delta E_{i t-1} * D \Delta E_{i t-1}+ \\
& \lambda_{7} T A_{i t-1}+\gamma_{1} a b_{-} \operatorname{Pr} o d_{i t}+\gamma_{2} a b_{-} D O_{i t}+\gamma_{3} a b_{-} C F O_{i t}+\varepsilon_{i t}
\end{aligned}
$$

em que:

$T A_{i t} \quad=$ accruals totais da empresa $i$ no período $t$

$R_{i t} \quad=$ receitas das vendas líquidas da empresa $i$ no período $t$, ponderadas pelos ativos totais no final do período $t-1$;

$C D_{i t} \quad=$ custos e despesas operacionais da empresa $i$ no período $t$, excetuando-se as despesas financeiras e despesas com depreciação, exaustão e amortização, ponderadas pelos ativos totais no final do período $t-1$;

$A I_{i t} \quad=$ ativo imobilizado da empresa $i$ no final do período $t$, ponderado pelos ativos totais no final do período $t-1$;

$A D_{i t} \quad=$ ativo diferido no final da empresa $i$ no final do período $t$, ponderado pelos ativos totais no final do período $t-1$;

$F C O_{i t}=$ fluxo de caixa operacional da empresa $i$ no período $t$, ponderado pelos ativos totais no final do período $t-1$;

$E_{i t} \quad=$ resultado contábil da empresa $i$ no período $t$, ponderado pelos ativos totais no final do período $t-1$;

$\Delta E_{i t-1}=$ variação no lucro líquido contábil da empresa $i$ do ano $t$-2 para o ano $t-1$ ponderada pelo valor do ativo total no início do ano $t-2$;

$D \Delta E_{i t-1} \quad=$ variável dummy para indicar se existe variação negativa no lucro líquido contábil da empresa $i$ do ano $t-2$ para o ano $t-1$, assumindo valor 1 se $\Delta N I_{i t}<0$, e 0 nos demais casos; 
$T A_{t-1}=$ accruals totais da empresa $i$ no período $t-1$, ponderados pelos ativos totais no final do período $t-2$;

$A b \_\operatorname{Prod}_{i t}=$ comportamento anormal dos custos de produção da empresa $i$ no período $t$;

$A b \_D O_{i t}=$ comportamento anormal das despesas operacionais da empresa $i$ no período $t$;

$A b_{-} C F O_{i t}=$ comportamento anormal dos fluxos de caixas operacionais da empresa $i$ no período $t$;

$\varepsilon_{i t} \quad=$ erro da regressão;

$\alpha, \beta$ 's, $\lambda$ 's e $\gamma^{\prime} s \quad=$ coeficientes estimados da regressão.

Como era esperado, o modelo operacional acima (Equação 4.15) apresenta-se complexo e não parcimonioso, devido ao amplo conjunto de fatores que influenciam em maior ou menor grau a formação dos accruals em um determinado período. Contudo, pode-se efetuar uma calibragem do modelo através dos testes de significância das variáveis explicativas e do erro aleatório, bem como utilização técnicas de análise multivariada, como Análise Fatorial, Análise de Clusters, entre outras.

Para fins de comparação do modelo proposto neste estudo com os demais modelos apresentados anteriormente, o Quadro 03 apresenta uma (nova) síntese dos problemas de especificação dos modelos existentes e do modelo proposto.

Como pode ser observado, existem limitações do modelo proposto devido à persistência de alguns problemas de especificação do modelo para a estimação dos accruals discricionários.

a) Controla adequadamente as mudanças dos accruals discricionários oriundas das condições econômicas:

Esse problema é de difícil (ou mesmo impossível) resolução total, pois provavelmente nenhum modelo operacional conseguirá controlar todos os fatores econômicos observáveis e não-observáveis que influenciam o comportamento dos accruals. Portanto, pode-se considerar que esse problema é uma questão de grau. Por outro lado, pode-se considerar que alguns fatores econômicos têm influência na disponibilidade de recursos financeiros da empresa e no seu desempenho econômico. Conseqüentemente, os efeitos de certas condições econômicas sobre o comportamento dos accruals poderiam ser capturados, parcialmente, pelas variáveis 'fluxo de caixa operacional' $\left(F C O_{i t}\right)$ e 'resultado do exercício' $\left(E_{i t}\right)$. 
Quadro 03 - Comparação dos problemas de especificação entre os modelos existentes e o modelo proposto para estimação dos accruals discricionários

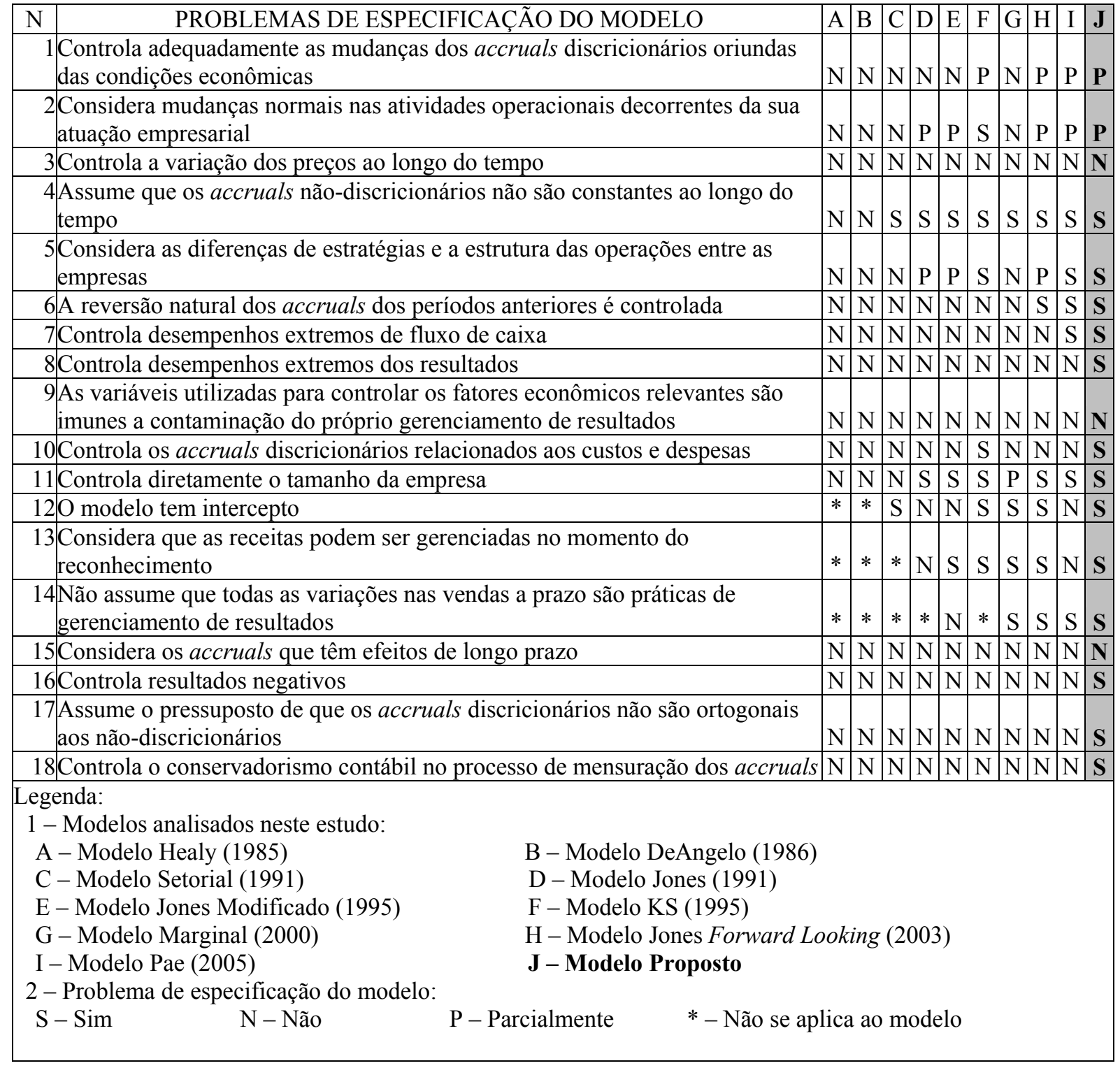

\section{b) Controla a variação dos preços ao longo do tempo}

Esse item está relacionado às limitações impostas pelas práticas contábeis vigentes, principalmente, a utilização do custo histórico na mensuração contábil. Uma forma de solucionar esse problema seria a utilização pelo pesquisador dos números contábeis mensurados pela Correção Integral adotada no Brasil nas décadas de 1980 e 1990 (FIPECAFI, 2007, p.554-572).

c) Variáveis utilizadas para controlar os fatores econômicos relevantes são imunes a contaminação do próprio gerenciamento de resultados 
As variáveis utilizadas nos modelos e mensuradas pelo próprio processo contábil são passíveis de contaminação pelo gerenciamento dos accruals, pois esse fato é originado pela dinâmica do processo de mensuração contábil. Pode-se considerar que, a única forma de solucionar esse problemas, seria através da identificação e emprego de variáveis exógenas à mensuração contábil, mas desde que guarde uma relação teórica e empírica relevante no comportamento dos accruals.

d) Considera os accruals que têm efeitos de longo prazo

Como exposto na suposição 04, o modelo proposto somente analisa os accruals de curto prazo, porque esses accruals devem ser revertidos no período subseqüente, facilitando a especificação do modelo, além da existência de evidências de que a prática oportunística dos gestores está mais voltada aos incentivos de curto prazo.

e) Assume o pressuposto de que os accruals discricionários não são ortogonais aos nãodiscricionários

Essa é uma limitação que pode ser avaliada, posteriormente, quando da estimação dos componentes gerenciados e não-gerenciados dos accruals. Caso se verifique que, os accruals discricionários são ortogonais aos não-discricionários, pode-se considerar que não existe esse problema de especificação no modelo proposto.

Por fim, torna-se oportuno avaliar o sinal esperado das estimativas das variáveis explicativas do modelo:

Quadro 04 - Explicação dos sinais esperados das variáveis explicativas do modelo proposto para estimação dos accruals discricionários

\begin{tabular}{|l|l|c|l|}
\hline \multicolumn{1}{|c|}{ Variável } & \multicolumn{1}{|c|}{ Descrição } & $\begin{array}{c}\text { Sinal } \\
\text { Esperado }\end{array}$ & \multicolumn{1}{c|}{ Justificativa } \\
\hline$\alpha$ & termo constante & $?$ & $\begin{array}{l}\text { Torna-se importante para o cálculo de } \\
\text { estimativas consistentes e não-enviesadas. }\end{array}$ \\
\hline $\mathrm{R}_{\mathrm{it}}$ & receitas das vendas líquidas & + & $\begin{array}{l}\text { Quanto maior o montante das receitas, } \\
\text { maior o volume de accruals positivos. }\end{array}$ \\
\hline $\mathrm{CD}_{\mathrm{it}}$ & custos e despesas operacionais & - & $\begin{array}{l}\text { Quanto maior o montante dos custos e } \\
\text { despesas, menor o valor total dos accruals. }\end{array}$ \\
\hline $\mathrm{AI}_{\mathrm{it}}$ & ativo imobilizado & - & $\begin{array}{l}\text { Quanto maior o valor do ativo imobilizado, } \\
\text { maior o volume de accruals originados da } \\
\text { depreciação, causando efeito negativo no } \\
\text { valor total dos accruals }\end{array}$ \\
\hline $\mathrm{AD}_{\mathrm{it}}$ & ativo diferido & - & $\begin{array}{l}\text { Quanto maior o valor do ativo diferido, } \\
\text { maior o volume de accruals originados da } \\
\text { amortização, causando efeito negativo no no } \\
\text { valor total dos accruals }\end{array}$ \\
\hline
\end{tabular}


Quadro 04 - Explicação dos sinais esperados das variáveis explicativas do modelo proposto para estimação dos accruals discricionários (continuação)

\begin{tabular}{|c|c|c|c|}
\hline Variável & Descrição & $\begin{array}{c}\text { Sinal } \\
\text { Esperado }\end{array}$ & Justificativa \\
\hline $\mathrm{FCO}_{\text {it }}$ & fluxo de caixa operacional & - & $\begin{array}{l}\text { Como exposto anteriormente, espera-se uma } \\
\text { relação inversa entre os accruals totais e o } \\
\text { fluxo de caixa operacional corrente. }\end{array}$ \\
\hline $\mathrm{E}_{\mathrm{it}}$ & resultado contábil & + & $\begin{array}{l}\text { Como exposto anteriormente, espera-se uma } \\
\text { relação direta entre os accruals totais e o } \\
\text { resultado contábil corrente. }\end{array}$ \\
\hline $\mathrm{E}_{\text {it }}^{2}$ & resultado contábil ao quadrado & $?$ & $\begin{array}{l}\text { Essa variável pretende capturar alguma } \\
\text { relação não-linear entre entre os accruals } \\
\text { totais e o resultado contábil corrente, sendo, } \\
\text { portanto, de dificil predição. }\end{array}$ \\
\hline$\Delta \mathrm{E}_{\mathrm{t}-1}$ & $\begin{array}{l}\text { variação no lucro líquido } \\
\text { contábil }\end{array}$ & $?$ & $\begin{array}{l}\text { Não se pode afirmar o comportamento } \\
\text { esperado do efeito de } 2^{\mathrm{a}} \text { ordem da 'variação } \\
\text { do resultado líquido' no modelo, por conta } \\
\text { da complexidade das relações entre } \\
\text { resultados, accruals e fluxo de caixa. Essa } \\
\text { variável, auxilia na avaliação do } \\
\text { comportamento conservador sobre os } \\
\text { accruals. }\end{array}$ \\
\hline $\mathrm{D} \Delta \mathrm{E}_{\mathrm{it}-1}$ & $\begin{array}{l}\text { variável dummy para indicar se } \\
\text { existe variação negativa no lucro } \\
\text { líquido contábil }\end{array}$ & $?$ & $\begin{array}{l}\text { No caso de reconhecimento oportuno, os } \\
\text { ganhos passam a ser um componente } \\
\text { transitório do resultado e tendem a ser } \\
\text { revertidos nos períodos subseqüentes. } \\
\text { Portanto, o coeficiente será menor (e } \\
\text { negativo) para empresas mais } \\
\text { conservadoras. }\end{array}$ \\
\hline$\Delta \mathrm{E}_{\mathrm{it}-1}^{*} \mathrm{D} \Delta \mathrm{E}_{\mathrm{it}-1}$ & $\begin{array}{l}\text { termo de interação entre } \Delta \mathrm{E}_{\mathrm{it}-1} \mathrm{e} \\
\mathrm{D} \Delta \mathrm{E}_{\mathrm{it}-1}\end{array}$ & - & $\begin{array}{l}\text { O reconhecimento mais oportuno das perdas } \\
\text { do que dos ganhos, implica que o } \\
\text { coeficiente seja menor que zero. }\end{array}$ \\
\hline $\mathrm{TA}_{\mathrm{it}-1}$ & accruals totais defasados & - & $\begin{array}{l}\text { Espera-se que os accruals do período } \\
\text { anterior seja revertido no período corrente }\end{array}$ \\
\hline Ab_Prod ${ }_{i t}$ & $\begin{array}{l}\text { comportamento anormal dos } \\
\text { custos de produção }\end{array}$ & + & $\begin{array}{l}\text { Um aumento anormal nos custos de } \\
\text { produção leva-se a um aumento anormal } \\
\text { dos accruals totais. Se o coeficiente for } \\
\text { significativamente diferente de zero } \\
\text { comprova a suposição de que parte dos } \\
\text { accruals são decorrentes do gerenciamento } \\
\text { das atividades operacionais, aumentando os } \\
\text { accruals discricionários totais. }\end{array}$ \\
\hline $\mathrm{Ab} \_\mathrm{DO}_{\text {it }}$ & $\begin{array}{l}\text { comportamento anormal das } \\
\text { despesas operacionais }\end{array}$ & + & $\begin{array}{l}\text { Um aumento anormal nas despesas } \\
\text { operacionais leva-se a um aumento anormal } \\
\text { dos accruals totais. Se o coeficiente for } \\
\text { significativamente diferente de zero } \\
\text { comprova a suposição de que parte dos } \\
\text { accruals são decorrentes do gerenciamento } \\
\text { das atividades operacionais, aumentando os } \\
\text { accruals discricionários totais. }\end{array}$ \\
\hline $\mathrm{Ab}_{-} \mathrm{CFO}_{\mathrm{it}}$ & $\begin{array}{l}\text { comportamento anormal do } \\
\text { fluxo de caixa operacional }\end{array}$ & $?$ & $\begin{array}{l}\text { Um comportamento anormal nos fluxos de } \\
\text { caixa operacional afeta os accruals totais, } \\
\text { porém não se pode estabelecer em qual } \\
\text { sentido por conta das diversas naturezas das } \\
\text { atividades operacionais que afetam o fluxo } \\
\text { de caixa. }\end{array}$ \\
\hline
\end{tabular}




\section{PROCEDIMENTOS METODOLÓGICOS}

\subsection{Tipo de Pesquisa}

Este trabalho se enquadra como uma pesquisa empírico-analítica, pois aborda técnicas matemáticas e estatísticas para análise quantitativa dos fenômenos, tendo forte preocupação com as relações causais entre as variáveis (MARTINS, Gilberto, 2002, p.33-34).

Caracteriza-se, também, como pesquisa bibliográfica pois busca explicar a natureza do gerenciamento de resultados contábeis a partir de referenciais teóricos extraídos das produções científicas publicadas em teses, dissertações ou artigos, com o intuito de analisar a construção dos modelos teóricos e analíticos para a mensuração do componente gerenciado dos resultados. A pesquisa bibliográfica, segundo Cervo e Bervian (2002, p.65-66), é utilizada nas pesquisas descritivas e experimentais com o objetivo de obter informações ou conhecimentos prévios referentes ao problema de pesquisa ou de uma determinada hipótese. A pesquisa descritiva, por sua vez, refere-se ao fato de o estudo "[...] observar, registrar, analisar e correlacionar fatos e fenômenos (variáveis) sem manipulá-los." (CERVO; BERVIAN, 2002, p.66).

\subsection{Hipóteses do trabalho}

Segundo Gilberto Martins (2002, p.41), a "hipótese é um enunciado conjetural das relações entre duas ou mais variáveis. Trata-se de suposições idealizadas na tentativa de antecipar respostas do problema de pesquisa."

As hipóteses de pesquisa auxiliam o pesquisador no desenvolvimento do seu trabalho, identificando fatos relevantes e não relevantes; para tanto, devem ser adequadas aos propósitos da pesquisa.

Para atender aos objetivos desta pesquisa, são levantadas algumas hipóteses acerca da eficiência dos modelos operacionais para estimar os accruals discricionários utilizados na detecção do gerenciamento de resultados contábeis. Com o intuito de verificar a especificação e o poder estatístico dos modelos estudados (modelos existentes na literatura e o modelo proposto), tem-se a primeira hipótese: 
Hipótese 1: Os modelos operacionais analisados apresentam evidências significativas para explicar o comportamento dos accruals e identificar os componentes discricionários presentes nos resultados contábeis das companhias abertas brasileiras, norte-americanas e dos demais países da América Latina.

A segunda hipótese refere-se à avaliação do desempenho dos modelos para a estimação de accruals discricionários para a detecção do gerenciamento de resultados através das escolhas contábeis, quando aplicados em ambientes econômicos distintos. Para tanto, é efetuada uma análise do poder explicativo dos modelos no contexto brasileiro, norte-americano e demais países da América Latina, podendo ser descrita da seguinte forma:

Hipótese 2: Os modelos operacionais para a estimação de accruals discricionários utilizados na detecção do gerenciamento de resultados apresentam diferenças significativas no poder preditivo quando aplicados em diversos ambientes econômicos.

Por fim, a terceira e última hipótese refere-se à comparação entre o modelo proposto neste trabalho e os modelos concorrentes para a estimação de accruals discricionários para a detecção do gerenciamento de resultados através das escolhas contábeis. Para tanto é efetuada uma análise comparativa desses modelos concorrentes em cada ambiente econômico, sendo descrita da seguinte forma:

Hipótese 3: O modelo operacional proposto neste trabalho para a estimação de accruals discricionários utilizados na detecção do gerenciamento de resultados apresenta maior poder explicativo do que os demais modelos concorrentes.

\subsection{Plano Amostral}

A população, neste estudo, é formada pelo conjunto de companhias abertas do mercado de capitais brasileiro, norte-americano e dos demais mercados latino-americanos: Argentina, Chile, Colômbia, México, Peru e Venezuela. 
As informações necessárias à pesquisa foram obtidas nos bancos de dados da Comissão de Valores Mobiliários (CVM), da Economática $^{59}$ e das demonstrações contábeis publicadas pelas companhias abertas, compreendendo o período de 1996 a 2005.

A fim de se evitar viés na amostra e problemas de especificação na estimação dos modelos, foram excluídas deste trabalho:

a) As companhias com dados ausentes necessários a este estudo e

b) As companhias que atuam na atividade financeira, tais como: bancos, seguradoras, previdência privada ou particular, administração de empresas e empreendimentos ou que tenham receitas operacionais exclusivamente oriundas de participações societárias.

Devido às características dos modelos utilizados, as instituições financeiras foram excluídas porque seus processos de mensuração de accruals se diferenciam substancialmente das demais companhias e, provavelmente, não são capturados adequadamente pelos modelos analisados. (PEASNELL et al, 2000, p.318).

Inicialmente, as empresas-ano que apresentaram dados numéricos com 04 desvios-padrão acima e abaixo da média (outlier) ${ }^{60}$ foram excluídas das amostras, sendo que esse procedimento é consistente com os de pesquisas empíricas anteriores (SUBRAMANYAM, 1996). Todavia, quando da análise sem o procedimento de exclusão dos outliers, os resultados não se apresentaram significativamente diferentes.

Diante dessa evidência, este trabalho segue a orientação exposta por Hair Jr. et al (2005, p.73) na qual sugerem que as variáveis atípicas (outliers) devem ser mantidas até que se encontrem provas consistentes de que a presença delas afeta significativamente os resultados.

\subsection{Definição do modelo empregado e variáveis operacionais}

Com base nos objetivos desta pesquisa, são utilizados os modelos operacionais presentes na literatura corrente sobre gerenciamento de resultados, tanto para a análise da sua construção no processo de modelagem, quanto para a sua análise empírica. Os modelos operacionais são

\footnotetext{
${ }^{59}$ O programa Economática é utilizado para fazer análises econômico-financeiras de empresas. Para maiores informações sobre o produto visite a home page http://www.economatica.com.br

${ }^{60}$ Seguindo sugestão efetuada por Hair Jr. et al (2005, p.720), na detecção univariada de observações atípicas para amostra acima de 80 observações.
} 
descritos e analisados no Capítulo 3, no qual é realizada uma análise teórica crítica sobre as suas construções.

As variáveis operacionais são descritas, juntamente, com os modelos no Capítulo 3. Quando da incorporação das variáveis ao modelo proposto de estimação de accruals discricionários para a detecção de gerenciamento de resultados, essas são conceituais conforme a teoria subjacente (seção 3.6).

\subsection{Análise da especificação e do poder preditivo de modelos concorrentes}

Inicialmente, todas regressões foram estimadas através da abordagem pooling of independent cross sections

É importante não confundir um pooling of independent cross sections com uma estrutura diferente de dados, dados em painel [...]. Resumidamente, em um conjunto de dados em painel, nós acompanhamos o mesmo grupo de indivíduos, firmas, cidades, etc. ao longo do tempo. Em um pooling of independent cross sections ao longo do tempo, não existe replicação de tempo. (Ou, se unidades aparecem em mais de um período de tempo, sua repetição é tratada como coincidente e ignorada $)^{61}$. (WOOLDRIGDE, 2001, p.129).

Para tanto, utilizou-se uma variável dummy ${ }^{62}$ para cada ano da amostra, exceto para os dados referentes ao ano de 1996, pois, conforme Wooldridge (2002, p.213) e Greene (2003,p. 118), o número de variáveis dummies a serem incluídas na regressão deve ser o número de categorias (grupos) menos um, porque, caso fosse a mesma quantidade (10 dummies para representar os 10 anos), se introduziria a colinearidade perfeita, visto que reproduziria o termo constante. Portanto, foram incluídas 9 variáveis dummies, referentes aos anos de 1997 a 2005. Segundo Wooldridge (2001, p.129-132; 2002, p.409-419), esse procedimento permite capturar os efeitos parciais das mudanças ao longo do tempo, sendo, portanto, útil à análise de políticas econômicas e sociais. A utilização de pooling of independent cross sections, também, aumenta o tamanho da amostra, o que possibilita a obtenção de estimadores mais precisos e estatísticas mais robustas.

Adicionalmente, o mesmo autor (2001, p.129) afirma que todos os métodos utilizados na cross section podem ser aplicados ao pooling of independent cross sections, incluindo as

\footnotetext{
${ }^{61}$ Tradução livre de: "It is important not to confuse a pooling of independent cross sections with a different data structure, panel data, which we treat starting in Chapter 7. Briefly, in a panel data set we follow the same group of individuals, firms, cities, and so on over time. In a pooling of cross sections over time, there is no replicability over time. (Or, if units appear in more than one time period, their recurrence is treated as coincidental and ignored.)",

${ }_{62}$ Conforme Greene (2003, p.116), a variável dummy é usualmente empregada com o objetivo de capturar algum efeito da característica qualitativa na regressão que também possua outras variáveis quantitativas.
} 
correções de heteroscedasticidade, testes de especificação, variáveis instrumentais, entre outros.

Observando a suposição 12 descrita na seção 3.6 deste trabalho, também, foram criadas variáveis dummies para cada setor da atividade econômica da empresa, exceto para a categoria 'Outros', conforme classificação estabelecida pelo banco de dados Economática. Com esse procedimento buscou-se, também, minimizar os problemas de heteroscedasticidade. Adicionalmente, somente para o contexto brasileiro, foram efetuadas as estimações de regressões em cross section e com dados em painel (panel data). O objetivo do emprego dessas abordagens é o de verificar as diferenças significativas entre as especificações dos modelos quando aplicados em técnicas diferentes de estimação.

A estimação com dados em painel utiliza as observações de séries temporais e cross section (seção cruzada), que, segundo Greene (2003, p.283), é comumente empregada em economia. Para Baltagi (2005, p.4-6), destacam-se, entre as vantagens da utilização de dados em painel, o controle da heterogeneidade individual, a maior capacidade para estudar a dinâmica dos ajustamentos e a possibilidade de modelar e analisar modelos comportamentais mais complexos.

$\mathrm{Na}$ abordagem de dados em painel, existem diferentes modelos para combinar os dados de séries temporais e cross-sectional, como os modelos de intercepto comum, efeitos fixos e efeitos aleatórios. Para verificar quais desses modelos é o mais adequado na estimação com dados em painel, Silva e Cruz Júnior (2004) sugerem os seguintes testes:

a) Modelo de intercepto comum versus modelo de efeitos fixos: Teste Chow: se a hipótese nula não for rejeitada, o modelo com intercepto comum tem a melhor especificação.

b) Modelo de intercepto comum versus modelo de efeitos aleatórios: Teste Chow $^{63}$ : se a hipótese nula não for rejeitada, o modelo com intercepto comum tem a melhor especificação.

c) Modelo de efeitos fixos versus modelo de efeitos aleatórios: Teste Hausman: se a hipótese nula não for rejeitada, o modelo de efeitos fixos tem a melhor especificação.

\footnotetext{
${ }^{63}$ Para identificar qual a melhor especificação entre o modelo com intercepto comum e efeitos aleatórios, Silva e Cruz Jr (2004, 585) sugerem, também, o teste baseado no Multiplicador de Langrange (LM), desenvolvido por Breusch e Pagan, considerando-o mais robusto que o teste Chow.
} 


\subsubsection{Análise dos pressupostos da regressão múltipla}

Madalla (1992), Wooldridge (2002) e Greene (2003) descrevem como principais pressupostos do modelo de regressão linear: (1) lineariedade; (2) exogeneidade das variáveis independentes; (3) distribuição normal dos resíduos; (4) homoscedasticidade; (5) ausência de autocorrelação e (6) multicolineariedade.

\section{Pressuposto 1 - Lineariedade}

O modelo de regressão linear descreve uma relação linear entre a variável dependente e as variáveis independentes. Greene $(2003$, p.11) afirma que esse pressuposto se refere à maneira pela qual os parâmetros e o erro aleatório são inseridos na especificação do modelo e, não necessariamente, na relação entre as variáveis. Portanto, a regressão deve ser linear nos parâmetros.

Dentro desse contexto, todos os modelos discutidos, neste trabalho, são lineares, pois seus parâmetros $(\beta s)$ são elevados à primeira potência.

\section{Pressuposto 2 - Exogeneidade}

Relata que o valor esperado do erro aleatório $\varepsilon_{i}$ na observação $i$ não é uma função da variável independente $X_{i}$ observada (GREENE, 2003, p.11), ou seja, nenhuma variável independente carrega informação sobre o valor esperado do erro aleatório, portanto, o valor esperado do erro aleatório dado $X_{i}$ é zero $\left(E\left[\varepsilon_{i} \mid X_{i}\right]=0\right)$.

Para esse pressuposto, foram efetuadas correlações entre as variáveis independentes e o erro aleatório para cada modelo e que são apresentadas nos apêndices deste trabalho.

\section{Pressuposto 3 - Distribuição normal dos resíduos}

Para Greene (2003, p.17), é conveniente assumir que os erros aleatórios sejam normalmente distribuídos, com média zero e variância constante. Contudo, o mesmo autor afirma que a normalidade não é necessária para obter muitos dos resultados da regressão múltipla, podendo esse pressuposto ser relaxado. Com base no teorema do limite central, Wooldridge (2002, p.167) afirma que os estimadores do método dos Mínimos Quadrados Ordinários (MQO) satisfazem a normalidade assintótica, ou seja, eles aproximadamente têm distribuição normal em amostras de tamanhos suficientemente grandes. Portanto, os coeficientes da regressão estimados pelo MQO são consistentes e não-viesados assintoticamente. 
Para analisar esse pressuposto, foi efetuado o teste de Jarque-Bera (GREENE, 2003, p.225), que é um teste estatístico para examinar se os dados são normalmente distribuídos, através das diferenças da assimetria (skewness) e da curtose (kurtosis) de uma série de dados com uma distribuição normal. A hipótese nula é que a distribuição é normal.

Com base no teste de Jarque-Bera, todos os modelos operacionais rejeitaram a hipótese nula de normalidade nos ambientes econômicos estudados neste trabalho. Todavia, apesar de apresentar o teste específico em cada estimação, o pressuposto da normalidade é relaxado nas inferências sobre os parâmetros dos modelos, pois seus coeficientes são consistentes e nãoviesados assintoticamente, como exposto anteriormente.

\section{Pressuposto 4 - Homoscedasticidade}

Significa que a variância do erro aleatório condicional nas variáveis explicativas é constante $\left(E\left[\varepsilon_{i} \mid X_{i}\right]=\sigma^{2}\right)$. Os resíduos da regressão são homoscedásticos quando a sua variância é constante, caso contrário, são considerados heteroscedásticos.

Wooldridge (2002, p. 248) afirma que a heteroscedasticidade não prova viés ou inconsistência nos estimados do MQO e não afeta as estimativas do $R^{2}$ e $R^{2}$ ajustado, mas os estimadores do MQO não serão assintoticamente os mais eficientes, assim, podem-se encontrar outros estimadores mais eficientes. Soares e Castelar (2003, p.198) sugerem que, quando não se conhece a função das variáveis explicativas que determina a heteroscedasticidade, pode-se estimar o modelo com erros-padrão corrigidos pela matriz de variância e covariância de White.

Como foi observado no Capítulo 3, os modelos operacionais têm apresentado dados heteroscedásticos nas pesquisas anteriores sobre o tema deste trabalho. Com o objetivo de melhorar as estimações dos parâmetros e, conseqüentemente, extrair inferências mais adequadas sobre os modelos analisados, foi utilizado o estimador de White para obter o erropadrão robusto em relação à heteroscedasticidade. Segundo Wooldridge (2002, p.252), os erros-padrão robustos são válidos com maior freqüência do que os erros-padrão usuais estimados pelo MQO, e, quando as hipóteses de normalidade e homoscedasticidade são observadas, as estatísticas $t$ usuais têm distribuição exata, independentemente do tamanho das amostras.

Mesmo com a utilização da correção de White, foram realizados testes para verificar se os resíduos são ou não homoscedásticos após o procedimento anteriormente indicado. $\mathrm{O}$ teste utilizado foi o Teste geral de heteroscedasticidade de White, pois esse método não é sensível ao pressuposto de normalidade e não necessita de ordenamento crescente dos dados como no 
teste de Goldfeld-Quandt (GREENE, 2003, p.222-223). Também, é realizado o teste de Koenker-Basset (teste KB), que, segundo Gujarati (2006, p.335), pode ser aplicado mesmo quando o termo de erro do modelo original não for normalmente distribuído e independente do número de regressores contidos no modelo.

\section{Pressuposto 5 - Ausência de autocorrelação}

O modelo clássico de regressão linear descreve que não pode existir correlação serial entre os resíduos. Da mesma forma que na presença de heteroscedasticidade, os estimadores do MQO permanecem não-enviesados e consistentes na presença de autocorrelação, mas também deixam de ser os mais eficientes, ou seja, não são os estimadores de menor variância.

Para analisar se existe autocorrelação nas estimações, este trabalho utilizou o teste de DurbinWatson e o teste LM de correlação serial de Breusch-Godfrey. (MADALLA, 1992, p. 230; GREENE, 2003, p.269).

\section{Pressuposto 6 - Multicolineariedade}

Quando duas ou mais variáveis explicativas apresentam alta correlação (não perfeita) é chamada de multicolineariedade. Soares e Castelar (2003, p.165) indicam que o problema da multicolineariedade surge quando a inclusão de uma nova variável independente afeta significativamente a estimação de outra variável à qual está correlacionada, diminuindo a significância da variável ou alterando o sinal da sua estimativa. Cabe lembrar que é rara a ausência total de multicolineariedade (regressores ortogonais), pois se espera que exista alguma correlação entre os regressores, portanto, o problema de multicolineariedade é, na realidade, um problema de grau.

Para verificar o grau de multicolinearidade entre as variáveis independentes, foi utilizado o teste Variance Inflation Factor - VIF (Fator de Inflação da Variância - FIV).(MADALLA, 1992, p. 2740; GREENE, 2003, p.57).

\section{Observações gerais sobre os pressupostos da regressão múltipla}

Com o intuito de analisar adequadamente as especificações dos modelos operacionais de estimação dos accruals (discricionários e não-discricionários), neste trabalho foram realizadas algumas transformações (padronizadas, logaritmo, inversa e raiz quadrada) nas variáveis originais dos modelos para solucionar eventuais problemas econométricos.

As estimações dos parâmetros e testes, com as variáveis transformadas para todos os modelos operacionais analisados, se encontram nos apêndices desta pesquisa. Porém, nenhuma das 
estimações com variáveis transformadas melhorou a especificação dos modelos com as variáveis originais e/ou resolveu os problemas relacionados aos pressupostos da regressão. Portanto, as inferências, contidas neste trabalho, referem-se exclusivamente às estimativas com as variáveis originais.

Quando da presença de multicolineariedade, efetuou-se a análise fatorial exploratória. Essa técnica tem como objetivo, descrever um conjunto de variáveis originais através da identificação de um menor número de dimensões ou fatores. Portanto, pode ser utilizado para reduzir o número de variáveis estabelecidas originalmente no modelo e/ou eliminar a correlação existentes entre duas ou mais variáveis da regressão (TABACHNICK; FIDELL, 2001; HAIR JR et al, 2005; PESTANA; GAGEIRO, 2005).

Adicionalmente, foi empregada a técnica multivariada de clusters analysis (procedimentos hierárquicos e não hierárquicos), que agrega objetos (neste estudo, empresas) com base nas similaridades ou dissimilaridades entre eles. Essa técnica teve como objetivo, minimizar a variabilidade das variáveis utilizadas por meio da agregação de empresas contidas na amostra. Porém, essa técnica não obteve o sucesso esperado, sendo que os relatórios das várias tentativas não são apresentados nesta pesquisa por seu extenso tamanho, diante do grande número de amostras (objetos) e variáveis utilizadas.

As estimações e testes estatísticos foram realizados nos pacotes estatísticos Eviews ${ }^{\circledR}$ versão 4.0 e $\operatorname{SPSS}^{\circledR}$ versão 15.

\subsubsection{Análise da especificação do modelo e escolha do melhor modelo}

A análise da especificação de modelos operacionais ainda está associada à omissão de variáveis relevantes, à inclusão de variáveis irrelevantes (inclusive causando problemas de multicolineariedade) e ao uso de proxies inadequadas de mensuração. ${ }^{64}$ A discussão sobre as proxies utilizadas neste trabalho está descrita no Capítulo 3.

Adicionalmente, ao discutido no Capítulo 3, a omissão de variáveis relevantes conduz a estimativas tendenciosas e inconsistentes, conseqüentemente, leva a inferências equivocadas sobre a hipótese testada. Por outro lado, a inclusão de variáveis irrelevantes leva a estimativas não tendenciosas e consistentes, mas ineficientes, o que torna as inferências sobre os parâmetros inexatas.

\footnotetext{
${ }^{64}$ Maiores discussões técnicas sobre análise de especificação de modelos foge do escopo deste trabalho. Para tanto, recomenda-se a leitura sobre o tema em Madalla (1992), Wooldridge (2002) e Greene (2003).
} 
Os testes para verificar a omissão (inclusão) de variáveis relevantes (irrelevantes) no modelo proposto foram realizados por meio do teste da razão de verossimilhança (RV) em cada ambiente econômico analisado neste trabalho. (SOARES; CASTELAR, 2003, p.106-125).

Para identificar qual dos modelos concorrentes tem a melhor especificação, usualmente, são empregados testes com base nos parâmetros estimados pelos modelos. Muitos testes estatísticos desenvolvidos para indicar a melhor especificação podem, somente, ser utilizados para testar nested models (modelos aninhados), ou seja, quando um modelo (modelo restrito) é um caso especial do outro modelo (modelo irrestrito ou amplo).

Segundo Wooldridge (2002, p.194), uma possibilidade seria a combinação dos modelos, realizando a estimação com todas as variáveis explicativas dos modelos originais e em seguida testar cada modelo contra o modelo geral pelo teste $F$ (teste $F$ abrangente).

Outra possibilidade é o teste $J$ (DAVIDSON; MACKINNON, 2003, p.657-659) que calcula os valores estimados de $y$ com base em um determinado modelo A $\left(y_{A}\right)$ e, em seguida, a variável $y_{A}$ é inserida em outro modelo (modelo B). Por fim, com auxilio do teste $t$, verifica-se se o coeficiente da variável $y_{A}$ é igual a zero no modelo B ampliado. No caso de não rejeitar a hipótese anterior, conclui-se que as variáveis contidas no modelo A (e que não estão originalmente em B) não acrescentam informação relevante para a estimação da variável dependente. Em seguida, efetuam-se, também, esses procedimentos, invertendo os modelos testados.

Porém, esses procedimentos (teste $F$ abrangente e teste $J$ ) podem rejeitar ou não ambos os modelos analisados, além da dificuldade adicional de relacionar mais de dois modelos nãoaninhados (non-nested).

Para a seleção de modelos non-nested, pode ser utilizado o Coeficiente de Determinação ajustado ( $R^{2}$ ajustado), que penaliza a perda de graus de liberdade quando o modelo é expandido, diferentemente do $R^{2}$. Contudo, cabe alertar que o uso do $R^{2}$ ajustado para escolher entre modelos non-nested tem uma limitação quando aplicados em escolhas entre formas funcionais diferentes da variável dependente, pois essas teriam diferentes montantes de variação a serem explicados. A utilização do grau de ajustamento ou Coeficiente de Determinação ajustado ( $R^{2}$ ajustado) para escolher o melhor modelo é consistente como outros trabalhos nessa linha de pesquisa contábil (SUBRAMANYAM, 1996; DECHOW et al, 2003).

Observe-se que, para alguns modelos, o pacote estatístico não estimou a estatística $F$, pelo fato de suas especificações não incluir o termo constante. É importante lembrar que a ausência 
do termo constante na especificação do modelo prejudica a estimação do $R^{2}$ ajustado como discutido anteriormente.

Além disso, como a penalidade imposta pelo $R^{2}$ ajustado não é suficientemente grande para assegurar que o pesquisador escolha o modelo adequado para amostras grandes, Greene (2003, p. 159) relata que existem outras formas alternativas para a escolha do melhor modelo, como, por exemplo, o Critério de Informação de Akaike (Akaike information criterion) e Critério de Informação de Schwartz ou bayesiano (Schwartz or Bayesian information criterion). Esses critérios também punem o acréscimo de regressores, porém de forma mais rigorosa do que o $R^{2}$ ajustado (principalmente o $S$ chwartz) e têm relação com a otimização de uma função de verossimilhança (WOOLDRIDGE, 2002; GREENE, 2003; DAVIDSON; MACKINNON, 2003).

Quando do emprego do Critério de Informação de Akaike e de Schwartz, considera-se que quanto menor o valor de suas estimativas, melhor a qualidade do ajustamento do modelo. Mas, Pindyck e Rubinfeld (2004, p.275) consideram que o $R^{2}$ ajustado, o Critério de Informação de Akaike e o Critério de Informação de Schwartz não "oferecem um teste estatístico claro para a comparação de especificações de modelos alternativos".

Diante das observações restritivas sobre a utilização do $R^{2}$ ajustado, Critérios de Akaike e Schwartz, utilizou-se, também, o teste proposto por Vuong (1989) para modelos non-nested (não-aninhados). O teste Vuong (como chamado neste trabalho) é baseado nas propriedades assintóticas da razão de verossimilhança. O teste permite indicar qual de dois modelos concorrentes analisados tem o maior poder explicativo, pois ele não obtém resultado ambíguo, como a aceitação ou rejeição de todos os modelos, como pode ocorrer nos testes $F$ e $J$. A análise do melhor modelo para estimação de accruals através do teste Vuong foi anteriormente utilizado por Dechow (1994).

Para a seleção do modelo, observa-se o seguinte processo (VUONG, 1989; DECHOW, 1994):

(a) estima-se a estatística $z$-vuong para os modelos A e B;

(b) considerando um nível de significância de 95\%, tem-se:

I - se $z$-vuong for menor que $-1,96(z$-vuong $<-1,96)$ - implica que o melhor é o modelo A;

II - se $z$-vuong for maior que $+1,96(z$-vuong $>+1,96)$ - implica que o melhor é o modelo B;

II - se $z$-vuong estiver entre $-1,96$ e $+1,96(-1,96>z$-vuong $>+1,96)-$ implica que não existe diferença significativa entre os modelos testados.

Adicionalmente, somente para o contexto brasileiro, os modelos operacionais concorrentes, estudados nesta pesquisa, são avaliados pela comparação da especificação e do poder 
estatístico através de simulação. A especificação de um modelo operacional é avaliada pelo exame da freqüência que geram Erro do Tipo I, enquanto o poder estatístico é examinado pela freqüência do Erro do Tipo II.

O Erro do Tipo I ocorre quando a hipótese nula é rejeitada, quando é verdadeira e o Erro do Tipo II surge quando a hipótese nula não é rejeitada, quando ela é falsa. (NEWBOLD et al, 2002, p.309; ANDERSON et al, 2002, p.327-328; GUJARATI, 2006, p.98).

Para tanto, é utilizado o método de simulação de Monte Carlo que auxilia nos estudos sobre as propriedades estatísticas dos vários métodos de estimação dos parâmetros da população (SOARES; CASTELAR, 2003, p. 77). Os procedimentos de simulação, adotados nesta pesquisa, são consistentes com os empregados em outros trabalhos que avaliam os modelos operacionais para detecção de gerenciamento de resultados (DECHOW et al, 1995; KANG, SIVARAMAKRISHNAN, 1995; PEASNELL et al, 2000).

Para Echambadi et al (2006, p. 1802), torna-se oportuno que as pesquisas corrijam as estimativas das relações entre as variáveis e minimizem os Erros do Tipo I e II na construção de modelos operacionais.

O teste da especificação dos modelos operacionais é efetuado através da freqüência em que ocorre o Erro do Tipo I. Neste trabalho, esse Erro surge quando o modelo de detecção falsamente rejeita a hipótese nula de gerenciamento de resultados.

A análise da especificação do modelo é feita através do nível que cada modelo rejeita incorretamente a hipótese nula de não gerenciamento dos resultados (Erro do Tipo I). Essa análise é efetuada por meio dos seguintes procedimentos:

a) Estimam-se os coeficientes das variáveis explicativas da regressão no primeiro estágio para cada um dos modelos analisados;

b) Calculam-se os accruals não-discricionários com base nos coeficientes estimados no item anterior;

c) Calculam-se os accruals discricionários conforme o Equação 3.11;

d) Selecionam-se $10 \%$ das empresas-ano aleatoriamente e constrói-se uma variável indicadora (PART), definida como ' 1 ' se a firma tem sido selecionada e, ' 0 ' caso contrário;

e) Estima-se a regressão simples abaixo para cada mensuração de accruals discricionários, e testa-se se o coeficiente estimado da variável PART é significativamente diferente de zero $(\beta \neq 0)$ 


$$
D A_{i}=\alpha+\beta P A R T_{i}+\varepsilon_{i}{ }^{65}
$$

f) Repetem-se os passos (a) a (e) 1000 vezes para cada modelo.

Por causa de as observações, no passo $d$, serem escolhidas aleatoriamente, elas não são caracterizadas por nenhuma prática sistemática de gerenciamento de resultados. Portanto, para um modelo de estimação de accruals bem especificado, não se espera rejeitar a hipótese nula $\left(\mathrm{H}_{0}: \beta=0\right)$ no nível de significância escolhido (níveis de 5\%). ${ }^{66}$ Conseqüentemente, considerase a rejeição das freqüências próximas do nível especificado, como evidência de que o modelo analisado está bem especificado. Caso contrário, se a rejeição das freqüências for significativamente diferente do nível especificado, então o modelo é pobremente especificado. $\mathrm{O}$ teste de poder estatístico refere-se à capacidade de detectar o gerenciamento de resultados realmente acontecido, ou seja, analisa se hipótese nula não é rejeitada, quando ela é falsa (Erro do Tipo II).

A análise do poder estatístico do modelo é baseada na capacidade de detectar uma prática discricionária (já conhecida), sendo que um nível prédeterminado de gerenciamento de resultados é artificialmente inserido. Para um conjunto selecionado aleatoriamente de empresas, é adicionado um montante positivo ou negativo de accruals discricionários e, em seguida, é examinada a capacidade de os modelos detectarem o gerenciamento artificial dos resultados.

A análise do poder estatístico dos modelos é desenvolvida através dos seguintes procedimentos:

a) Selecionam-se $10 \%$ das empresas-ano aleatoriamente e constrói-se uma variável indicadora (PART), definida como ' 1 ' se a firma tem sido selecionada e ' 0 ' caso contrário. Para as empresas com a variável PART igual a ' 1 ', será artificialmente induzida o gerenciamento de resultados através de: (i) aumento randômico (de $0,1 \%$ a $5 \%$ ) de accruals positivos das receitas líquidas e (ii) diminuição randômica (de $0,1 \%$ a $5 \%)$ das despesas operacionais.

b) Com base no item anterior, estimam-se os coeficientes das variáveis explicativas da regressão no primeiro estágio para cada um dos modelos analisados;

\footnotetext{
${ }^{65}$ Modelo teórico/operacional para detecção de gerenciamento de resultados (Equação 3.05) proposto por McNichols e Wilson (1988) e discutido no capítulo 3 deste trabalho.

${ }^{66}$ Para Dechow et al (1995, p.200), este procedimento é simplesmente um teste para verificar se pressupostos de Gaussian sobre regressão são satisfeitos.
} 
c) Calculam-se os accruals não-discricionários com base nos coeficientes estimados no item anterior;

d) Calculam-se os accruals discricionários conforme o Equação 3.11;

e) Estima-se a regressão simples abaixo para cada mensuração de accruals discricionários e testa-se se o coeficiente estimado da variável PART é significativamente diferente de zero $(\beta \neq 0)$

$$
D A_{i}=\alpha+\beta P A R T_{i}+\varepsilon_{i}
$$

f) Repetem-se os passos (a) a (e) 1000 vezes para cada modelo.

Diante do fato de que para as empresas com a variável PART igual a 1 foram adicionados accruals gerenciados artificialmente, espera-se que a hipótese nula de coeficiente estimado da variável PART igual a zero seja rejeitada e o coeficiente seja significativamente maior que zero $(\beta>0)$.

A manipulação das receitas é considerada como seu reconhecimento antecipado, tendo em conta que todos os custos são fixos, aumentando o montante prédeterminado da manipulação das receitas nos accruals totais, receitas totais e clientes.

A manipulação das despesas é considerada como seu reconhecimento atrasado, através da diminuição de um montante de despesas, das contas a pagar e dos accruals negativos.

Dechow et al (1995) e Kang e Shivaramakrishnan (1995) fazem os ajustes correspondentes dos accruals discricionários artificiais através da reversão nos períodos posteriores, enquanto Peasnell et al (2000, p.318) não realiza nenhum ajuste. Por causa da natureza contábil dos accruals, neste trabalho optou-se por realizar os ajustes dos accruals artificiais nos períodos posteriores. 


\subsection{Análise descritiva das variáveis}

Inicialmente, realizou-se uma análise descritiva do conjunto de observações. Conforme descrito no Capítulo 4 (Procedimentos metodológicos), a população, neste estudo, foi o conjunto de companhias abertas presentes nos mercados de capitais da América Latina e dos Estados Unidos da América. As informações necessárias para a pesquisa foram coletadas nos bancos de dados da Comissão de Valores Mobiliários (CVM), Economática e das demonstrações contábeis publicadas pelas empresas, compreendendo o período de 1996 a 2005. A formação do universo amostral de cada país está descrita na tabela abaixo.

Tabela 12 - Formação da amostra da pesquisa

\begin{tabular}{|c|c|c|c|c|c|c|c|c|}
\hline & 武 & 咅 & 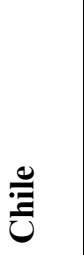 & ن & 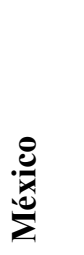 & ᄅ: & 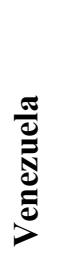 & 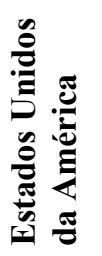 \\
\hline $\begin{array}{l}\text { Total de empresas presentes } \\
\text { nos bancos de dados }\end{array}$ & 578 & 100 & 284 & 69 & 183 & 171 & 49 & 1.470 \\
\hline $\begin{array}{l}\text { Empresas que atuam na } \\
\text { atividade financeira e de } \\
\text { participações societárias }\end{array}$ & $(49)$ & (8) & $(66)$ & $(30)$ & $(27)$ & (19) & $(18)$ & $(402)$ \\
\hline Falta de informações & $(69)$ & (17) & (26) & (8) & $(10)$ & (36) & (6) & $(152)$ \\
\hline Amostra & 460 & 75 & 192 & 31 & 146 & 116 & 25 & 916 \\
\hline
\end{tabular}

As companhias abertas que exercem atividades financeiras e aquelas que têm como objeto principal a participação em outras empresas foram excluídas, conforme plano amostral descrito na seção 4.3. Também, foram excluídas as empresas que não tinham as informações necessárias à estimação dos accruals discricionários.

Conforme a Tabela 12, Argentina, Colômbia e Venezuela possuem menos de 100 empresas para o desenvolvimento desta pesquisa, então, para esses países não foram estimados os parâmetros dos modelos operacionais, pois a verificação dos pressupostos da regressão múltipla (exogeneidade, normalidade, homoscedasticidade, ausência de autocorrelação e multicolineariedade), a análise da especificação e escolha de modelos pode não ser adequadamente realizadas para pequenas amostras. 
A composição das empresas por ramo de atividade econômica é apresentada na Tabela 13 para Brasil, Chile, México, Peru e Estados Unidos da América (EUA).

Tabela 13 - Composição da amostra de cada país

\begin{tabular}{|c|c|c|c|c|c|}
\hline Setor & Brasil & Chile & México & Peru & EUA \\
\hline Agropecuária e Pesca & 3 & 23 & 4 & 10 & 1 \\
\hline Alimentos e Bebidas & 36 & 16 & 22 & 16 & 25 \\
\hline Comércio & 21 & 20 & 30 & 2 & 57 \\
\hline Construção & 18 & 2 & 12 & 3 & 16 \\
\hline Eletroeletrônicos & 17 & 1 & 2 & 3 & 123 \\
\hline Energia Elétrica & 45 & 23 & 0 & 9 & 40 \\
\hline Máquinas Industriais & 9 & 0 & 4 & 5 & 37 \\
\hline Mineração & 4 & 7 & 3 & 19 & 30 \\
\hline Minerais não Metais & 7 & 6 & 8 & 5 & 5 \\
\hline Papel e Celulose & 9 & 2 & 3 & 0 & 16 \\
\hline Petróleo e Gás & 9 & 2 & 0 & 1 & 79 \\
\hline Química & 36 & 9 & 6 & 7 & 95 \\
\hline Siderurgia e Metalurgia & 45 & 7 & 9 & 5 & 22 \\
\hline Software e Dados & 1 & 0 & 0 & 0 & 70 \\
\hline Telecomunicações & 61 & 9 & 7 & 3 & 32 \\
\hline Têxtil & 33 & 5 & 5 & 9 & 8 \\
\hline Transporte Serviços & 15 & 8 & 4 & 0 & 29 \\
\hline Veículos e Peças & 26 & 0 & 2 & 1 & 23 \\
\hline Outros & 65 & 52 & 25 & 18 & 208 \\
\hline Total da amostra & 460 & 192 & 146 & 116 & 916 \\
\hline
\end{tabular}

Os dados da estatística descritiva e do teste de normalidade das variáveis 'accruals totais', 'fluxo de caixa operacional' e 'resultado líquido' utilizados encontram-se na Tabela 14. Com o intuito de se verificar a normalidade, foi utilizado o Teste Jarque-Bera. Para o período analisado, pode-se verificar que existem evidências estatísticas para rejeitar a normalidade das variáveis, ou seja, as variáveis accruals totais (TA), fluxo de caixa operacional (FCO) e resultado líquido (E) não seguem uma distribuição normal, considerando-se um nível de significância de 0,05 (NEWBOLD et al; 2002; WOOLDRIDGE, 2002; GREENE, 2003). 
Tabela 14 - Estatística descritiva das variáveis

\begin{tabular}{l|r|r|r|r|r|r|r|r}
\hline & Média & Mediana & $\begin{array}{c}\text { Desvio- } \\
\text { padrão }\end{array}$ & \multicolumn{1}{c|}{$\begin{array}{c}\text { Assime- } \\
\text { tria }\end{array}$} & Curtose & \multicolumn{2}{|c|}{ Jarque Bera Test } & n \\
coeficiente & p-value & \\
\hline Painel A - Brasil & & & & & & & & \\
Accruals Totais & $-0,045$ & $-0,038$ & 0,198 & $-0,030$ & 52,365 & 306445 & 0,000 & 3014 \\
Fluxo de Caixa Operacional & 0,095 & 0,098 & 0,412 & $-22,902$ & 1041,137 & 153605228 & 0,000 & 3014 \\
Resultado Líquido & $-0,052$ & 0,014 & 0,631 & $-17,791$ & 519,429 & 36242205 & 0,000 & 3014 \\
Painel B - Chile & & & & & & & & \\
Accruals Totais & $-0,022$ & $-0,030$ & 0,197 & 8,444 & 145,745 & 1310265 & 0,000 & 1522 \\
Fluxo de Caixa Operacional & 0,076 & 0,079 & 0,209 & 11,003 & 346,607 & 7518060 & 0,000 & 1522 \\
Resultado Líquido & 0,028 & 0,042 & 0,177 & $-5,290$ & 53,317 & 167655 & 0,000 & 1522 \\
Painel C - México & & & & & & & & \\
Accruals Totais & $-0,023$ & $-0,030$ & 0,162 & 1,459 & 39,019 & 67633 & 0,000 & 1243 \\
Fluxo de Caixa Operacional & 0,121 & 0,116 & 0,154 & 2,122 & 40,051 & 72029 & 0,000 & 1243 \\
Resultado Líquido & 0,033 & 0,046 & 0,194 & 0,768 & 143,367 & 1020565 & 0,000 & 1243 \\
Painel D - Peru & & & & & & & & \\
Accruals Totais & $-0,026$ & $-0,032$ & 0,290 & 0,999 & 164,782 & 1069996 & 0,000 & 981 \\
Fluxo de Caixa Operacional & 0,035 & 0,062 & 0,647 & $-18,241$ & 383,379 & 5968526 & 0,000 & 981 \\
Resultado Líquido & 0,032 & 0,028 & 0,161 & 4,994 & 131,128 & 675110 & 0,000 & 981 \\
Painel E - EUA & & & & & & & & \\
Accruals Totais & $-0,042$ & $-0,040$ & 0,128 & $-6,714$ & 206,377 & 12973387 & 0,000 & 7495 \\
Fluxo de Caixa Operacional & 0,113 & 0,104 & 0,133 & $-2,516$ & 44,556 & 547195 & 0,000 & 7495 \\
Resultado Líquido & 0,039 & 0,046 & 0,202 & $-16,237$ & 636,002 & $1,25 \mathrm{E}+08$ & 0,000 & 7495 \\
\hline
\end{tabular}

Accruals Totais (TA) $=\left[\left(\Delta \mathrm{AC}_{\mathrm{t}}-\Delta \mathrm{Disp}_{\mathrm{t}}\right)-\left(\Delta \mathrm{PC}_{\mathrm{t}}-\Delta \mathrm{Div}_{\mathrm{t}}\right)-\mathrm{Depr}_{\mathrm{t}}\right] / \mathrm{A}_{\mathrm{t}-1}$

$\mathrm{Ac}_{\mathrm{t}}=$ accruals (operacionais) totais da empresa no período $t ; \Delta \mathrm{AC}_{\mathrm{t}}=$ variação do ativo corrente (circulante) da empresa no final do período $t-1$ para o final do período $t ; \Delta \mathrm{PC}_{\mathrm{t}}=$ variação do passivo corrente (circulante) da empresa no final do período $t-1$ para o final do período $t ; \Delta$ Disp $_{t}=$ variação das disponibilidades da empresa no final do período $t-1$ para o final do período $t ; \Delta \operatorname{Div}_{\mathrm{t}}=$ variação dos financiamentos e empréstimos de curto prazo da empresa no final do período $t-1$ para o final do período $t ;$ Depr $_{\mathrm{t}}=$ montante das despesas com depreciação e amortização da empresa durante o período $t ; \mathrm{A}_{\mathrm{t}-1}=$ ativos totais da empresa no final do período $t-1$.

Fluxo de Caixa Operacional (FCO): Para as companhias do Brasil, Peru e México, o FCO foi obtido pela reconstituição da Demonstração do Fluxo de Caixa através do método indireto, enquanto para Chile e EUA foi coletado diretamente da Demonstração de Fluxo de Caixa.

Resultado Líquido (E): obtido diretamente da Demonstração de Resultados do Exercício.

Todas as variáveis ponderadas pelo ativo total no final do ano $t-1$

Os coeficientes de correlação de Pearson (teste paramétrico) e a de Spearman (nãoparamétrico) entre as variáveis de cada país estão, respectivamente, descritos nas Tabelas 15 e 16. Devido à rejeição da normalidade das variáveis, o teste mais indicado é o teste nãoparamétrico de Spearman. (LEVIN; FOX, 2004, p.293-294).

Em ambos os testes, constata-se que existe uma correlação negativa significativa entre os accruals totais correntes $\left(T A_{t}\right)$ e o fluxo de caixa corrente $\left(F C O_{t}\right)$, com exceção da correlação de Pearson para a amostra dos EUA e de Spearman para a amostra do México. Como esperado, os testes demonstram a existência de correlação significativamente positiva entre os accruals totais correntes $\left(T A_{t}\right)$ e o resultado líquido corrente $\left(E_{t}\right)$, excetuando-se para as amostras do Chile e dos Estados Unidos da América referentes à correlação de Pearson. Essas evidências confirmam as relações preditas por Dechow e Dichev (2002) e corroboram a 
relevância da inclusão das variáveis $F C O_{t}$ e $E_{t}$ no modelo proposto, conforme as suposições 8 e 9 assumidas anteriormente.

Tabela 15 - Análise de correlação de Pearson

\begin{tabular}{|c|c|c|c|c|c|}
\hline & $T A_{t}$ & $\mathrm{FCO}_{\mathrm{t}}$ & $\mathbf{E}_{\mathrm{t}}$ & $T A_{t-1}$ & $\mathrm{FCO}_{\mathrm{t}-1}$ \\
\hline \multicolumn{6}{|c|}{ Panel A - Brasil } \\
\hline$T A_{t}$ & 1,000 & $-0,273^{* *}$ & $0,062^{* *}$ & $0,190^{* *}$ & $-0,078^{* *}$ \\
\hline $\mathrm{FCO}_{t}$ & $-0,273^{* *}$ & 1,000 & $0,418^{* *}$ & $0,039^{*}$ & $0,542^{* *}$ \\
\hline$E_{t}$ & $0,062^{* *}$ & $0,418^{* *}$ & 1,000 & $0,169^{* *}$ & $0,435^{* *}$ \\
\hline$T A_{t-1}$ & $0,190^{* *}$ & $0,039^{*}$ & $0,169^{* *}$ & 1,000 & $-0,267^{* *}$ \\
\hline$F C O_{t-1}$ & $-0,078^{* *}$ & $0,542^{* *}$ & $0,435^{* *}$ & $-0,267^{* *}$ & 1,000 \\
\hline \multicolumn{6}{|c|}{ Panel B - Chile } \\
\hline$T A_{t}$ & 1,000 & $-0,130^{* *}$ & 0,050 & $-0,018$ & $-0,072^{* *}$ \\
\hline $\mathrm{FCO}_{t}$ & $-0,130^{* *}$ & 1,000 & $0,812^{* *}$ & $-0,135^{* *}$ & $0,516^{* *}$ \\
\hline$E_{t}$ & 0,050 & $0,812^{* *}$ & 1,000 & $-0,074^{* *}$ & $0,509^{* *}$ \\
\hline$T A_{t-1}$ & $-0,018$ & $-0,135^{* *}$ & $-0,074^{* *}$ & 1,000 & $-0,201^{* *}$ \\
\hline$F C O_{t-1}$ & $-0,072^{* *}$ & $0,516^{* *}$ & $0,509^{* *}$ & $-0,201^{* *}$ & 1,000 \\
\hline \multicolumn{6}{|c|}{ Panel C - México } \\
\hline$T A_{t}$ & 1,000 & $-0,133^{* *}$ & $0,406^{* *}$ & $0,111^{* *}$ & 0,046 \\
\hline$F C O_{t}$ & $-0,133^{* *}$ & 1,000 & $0,305^{* *}$ & 0,027 & $0,294^{* *}$ \\
\hline$E_{t}$ & $0,406^{* *}$ & $0,305^{* *}$ & 1,000 & $0,115^{* *}$ & $0,166^{* *}$ \\
\hline$T A_{t-1}$ & $0,111^{* *}$ & 0,027 & $0,115^{* *}$ & 1,000 & $-0,137^{* *}$ \\
\hline$F C O_{t-1}$ & 0,046 & $0,294^{* *}$ & $0,166^{* *}$ & $-0,137^{* *}$ & 1,000 \\
\hline \multicolumn{6}{|c|}{ Panel D - Peru } \\
\hline$T A_{t}$ & 1,000 & $-0,218^{* *}$ & $0,178^{* *}$ & 0,034 & $-0,097^{* *}$ \\
\hline$F C O_{t}$ & $-0,218^{* *}$ & 1,000 & $-0,548^{* *}$ & 0,038 & $0,647^{* *}$ \\
\hline$E_{t}$ & $0,178^{* *}$ & $-0,548^{* *}$ & 1,000 & $-0,036$ & $-0,381^{* *}$ \\
\hline$T A_{t-1}$ & 0,034 & 0,038 & $-0,036$ & 1,000 & $-0,197^{* *}$ \\
\hline$F C O_{t-1}$ & $-0,097^{* *}$ & $0,647^{* *}$ & $-0,381^{* *}$ & $-0,197^{* *}$ & 1,000 \\
\hline \multicolumn{6}{|c|}{ Panel E - EUA } \\
\hline$T A_{t}$ & 1,000 & $-0,019$ & 0,010 & $-0,019$ & $-0,023$ \\
\hline $\mathrm{FCO}_{t}$ & $-0,019$ & 1,000 & $0,497^{* *}$ & $-0,026^{*}$ & $0,655^{* *}$ \\
\hline$E_{t}$ & 0,010 & $0,497^{* *}$ & 1,000 & $0,109^{* *}$ & $0,386^{* *}$ \\
\hline$T A_{t-1}$ & $-0,019$ & $-0,026^{*}$ & $0,109^{* *}$ & 1,000 & $-0,105^{* *}$ \\
\hline$F C O_{t-1}$ & $-0,023$ & $0,655^{* *}$ & $0,386^{* *}$ & $-0,105^{* *}$ & 1,000 \\
\hline
\end{tabular}

** Correlação é significativa a nível de 0,01 (bi-caudal).

Analisando-se somente as estatísticas descritas pela correlação não-paramétrica de Spearman (Tabela 16), observa-se que, no contexto peruano, a variável 'accruals totais defasados' ( $T A_{t-}$ 1) não tem correlação significativa com os accruals totais correntes $\left(T A_{t}\right)$, enquanto nos demais ambientes, o sinal de correlação é diferente do esperado.

Assim, as relações esperadas entre essas variáveis, conforme descritas por Dechow e Dichev (2002), a relevância das variáveis $F C O_{t}$ e $T A_{t-1}$ no modelo proposto é avaliada na seção seguinte, quando da a estimação dos accruals discricionários pelos modelos. 
Tabela 16 - Análise de correlação de Spearman

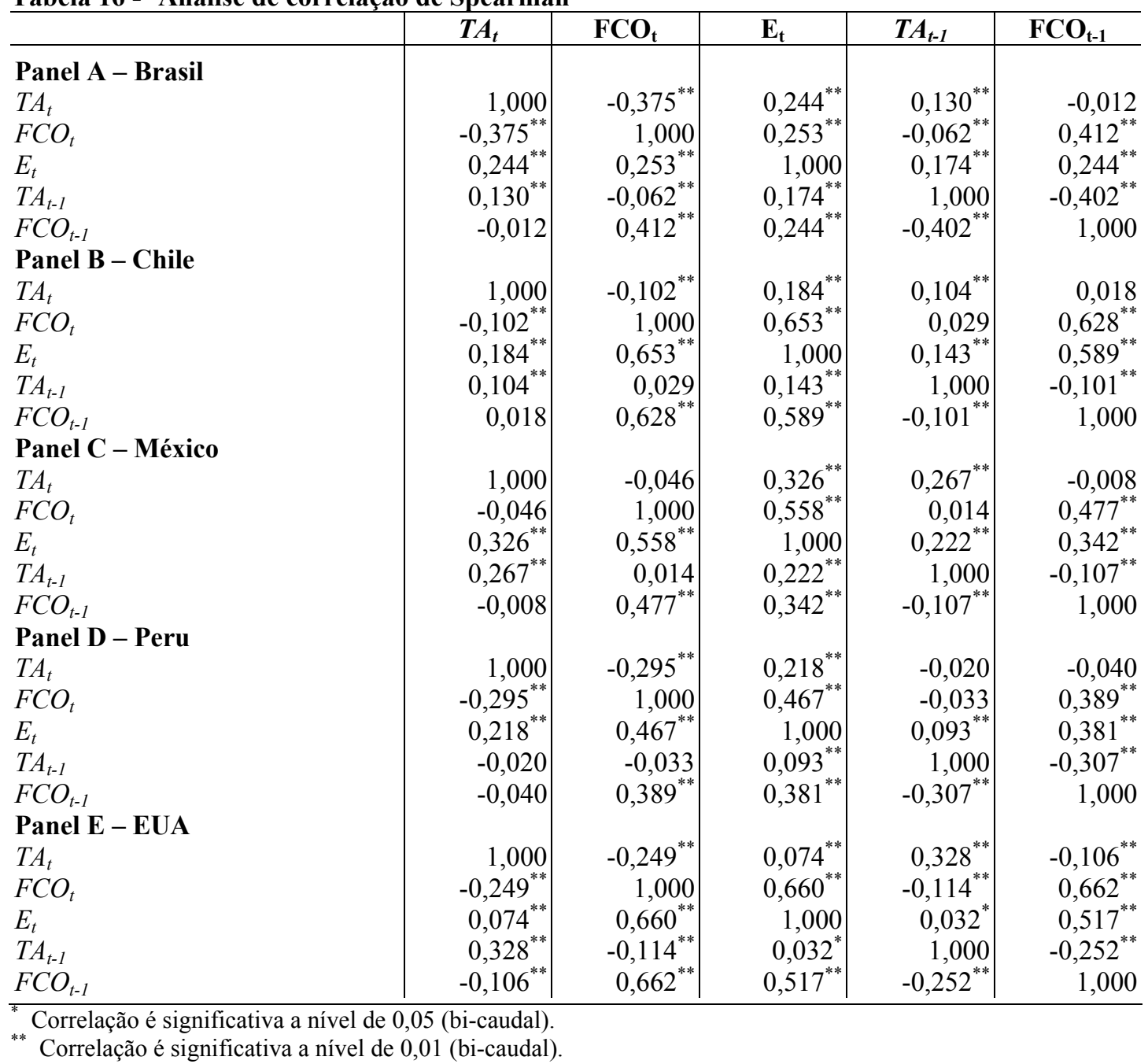

\subsection{Análise da especificação dos modelos operacionais para a estimação dos accruals discricionários}

Inicialmente, são apresentadas e discutidas as estimações dos parâmetros e testes sobre a especificação dos modelos analisados. Nesse primeiro momento procuram-se apurar evidências que corroborem ou não a Hipótese 1 descrita na seção 4.2, que busca verificar se os modelos propostos explicam o comportamento dos accruals.

Com base na Hipótese 2, foi efetuada uma análise comparativa sobre o poder preditivo dos modelos, por meio das estimativas $\mathrm{R}^{2}$ ajustado, Critério de Informação de Akaike, Critério de Informação de Schwarz e teste de Vuong. Adicionalmente, foi realizada uma análise da especificação do modelo por meio da simulação de Monte Carlo para o ambiente brasileiro. 
As regressões foram estimadas através da abordagem pooling of indepedent cross section. Como descrito na seção 4.5, nas estimações dos parâmetros controlou-se as características do setor da atividade econômica da empresa ${ }^{67}$ e utilizou-se o estimador de White para obter o erro-padrão robusto em relação à heteroscedasticidade.

Posteriormente, foram efetuadas as estimações dos modelos por dados em painel e por cross section para cada ano, para verificar se existem diferenças significativas entre as especificações dos modelos quando aplicados em técnicas diferentes de estimação.

\subsubsection{Brasil}

Nas Tabelas 17, 18 e 19, são apresentadas as estimações para os parâmetros e testes estatísticos de cada modelo através de pooling of indepedent cross section nas companhias brasileiras. Com base no teste de Jarque-Bera, todos os modelos operacionais rejeitam a hipótese nula de normalidade, mas, observando as propriedades assintóticas, os estimadores do método dos Mínimos Quadrados Ordinários (MQO) satisfazem a normalidade assintótica, conseqüentemente, os coeficientes são consistentes e não-viesados assintoticamente (WOOLDRIDGE, 2002, p.167).

Observando os Apêndices 1 e 2 deste trabalho verificou-se que todos os modelos no contexto brasileiro atendem ao pressuposto da exogeneidade, pois não existe forte correlação entre os resíduos e as variáveis explicativas.

O modelo Setorial, aplicado no contexto brasileiro, apresenta homoscedasticidade nos resíduos, entretanto, existe evidência de autocorrelação dos resíduos. Adicionalmente, observa-se um baixo poder de explicação $\left(R^{2}=0,030\right)$, mesmo considerando que a estatística $F$ indique que a mediana dos accruals totais explica o comportamento dos accruals totais e que o coeficiente da única variável utilizada é positiva e significativamente diferente de zero, como predito para o modelo. Nesse modelo, não existe problema de multicolineariedade porque utiliza somente uma variável explicativa.

O modelo Jones (1991) tem um $R^{2}$ ajustado baixo $(0,070)$ e os testes detectaram heteroscedasticidade e presença de correlação serial. $\mathrm{O}$ coeficiente da variável $P P E_{i t}$ está consistente com o comportamento esperado, ou seja, significativamente menor que zero e o

\footnotetext{
${ }^{67}$ Quando os coeficientes das variáveis dummies para controlar o setor da atividade econômica da empresa forem estatisticamente significativos, eles são descritos e analisados no corpo do texto.
} 
coeficiente da variável $\Delta R_{i t}$ também é diferente de zero, mas não se pode predizer o sinal esperado devido à ambigüidade da variável.

A estimação do modelo Jones evidencia que os coeficientes das variáveis dummies para os setores de energia elétrica $(0,028)$, construção $(0,038)$, telecomunicação $(-0,075)$ e veículos e peças $(-0,060)$ são significativamente diferentes de zero, considerando um nível de significância de 5\%.

Tabela 17 - Estimação dos modelos operacionais no contexto brasileiro - Parte A

\begin{tabular}{|c|c|c|c|c|c|c|}
\hline & \multicolumn{2}{|c|}{ Setorial } & \multicolumn{2}{|c|}{ Jones } & \multicolumn{2}{|c|}{$\mathbf{K S}^{68}$} \\
\hline & coeficiente & p-value & coeficiente & p-value & coeficiente & p-value \\
\hline Constante & 0,002 & 0,829 & & & $-0,037$ & 0,013 \\
\hline Mediana TA & 1,176 & 0,000 & & & & \\
\hline $1 / \mathrm{A}_{\mathrm{it}-1}$ & & & 1,488 & 0,326 & & \\
\hline$\Delta \mathrm{R}_{\mathrm{it}}$ & & & 0,104 & 0,004 & & \\
\hline $\mathrm{PPE}_{\text {it }}$ & & & $-0,065$ & 0,000 & $-0,195$ & 0,000 \\
\hline $\mathrm{R}_{\mathrm{it}}$ & & & & & 0,095 & 0,007 \\
\hline $\mathrm{D}_{\mathrm{it}}$ & & & & & $-0,050$ & 0,064 \\
\hline$R^{2}$ & 0,030 & & 0,070 & & 0,067 & \\
\hline$R^{2}$ ajustado & 0,027 & & 0,061 & & 0,057 & \\
\hline Akaike criterion & $-0,424$ & & $-0,452$ & & $-0,553$ & \\
\hline Schwarz criterion & $-0,402$ & & $-0,394$ & & $-0,489$ & \\
\hline Estatística $F$ & 9,511 & 0,000 & & & 6,884 & 0,000 \\
\hline White Heteroskedastici & & & & & & \\
\hline Test & 17,425 & 0,625 & 598,416 & 0,000 & 614,506 & 0,000 \\
\hline KB Tes & $-0,722$ & 0,508 & 2,899 & 0,000 & 0,247 & 0,086 \\
\hline Durbin-Watson & 1,609 & & 1,632 & & 1,682 & \\
\hline Breusch-Godfrey Serial & & & & & & \\
\hline on LM Test & 80,116 & 0,000 & 75,211 & 0,000 & 60,580 & 0,000 \\
\hline Jarque-Bera Test & 336415 & 0,000 & 277985 & 0,000 & 460104 & 0,000 \\
\hline Observaçõesr & 3018 & & 3009 & & 2801 & \\
\hline
\end{tabular}

O modelo KS, estimado através do método de variáveis instrumentais (IV), também apresenta heteroscedasticidade (somente pelo teste de White), autocorrelação e baixo grau de ajustamento. As estimativas das variáveis apresentam o sinal esperado, mas a variável $D_{t}$ não é significativa para a predição dos accruals. Analisando-se a correlação de Pearson (Apêndice 1) e a de Spearman (Apêndice 2) entre as variáveis explicativas e as respectivas variáveis instrumentais, observa-se que, apesar de significativas, as correlações entre elas não são fortes, o que indica que as variáveis instrumentais preditas por Kang e Sivaramakrishnan (1995) não são medidas adequadas para auxiliar na estimação do modelo, apesar de apresentarem baixas correlações com o erro aleatório. No modelo KS, as variáveis dummies

\footnotetext{
${ }^{68}$ A abreviatura KS representa o Modelo KS estimado pelo método das variáveis instrumentais, enquanto a abreviatura KS MQO representa o Modelo KS sem a utilização das variáveis instrumentais, ou seja, os parâmetros são estimados pelo método dos mínimos quadrados ordinários (MQO ou OLS).
} 
para os setores de construção $(0,034)$, siderurgia e metalurgia $(0,035)$, telecomunicação ($0,063)$ e veículos e peças $(-0,037)$ têm coeficientes significativamente diferentes de zero.

Tabela 18 - Estimação dos modelos operacionais no contexto brasileiro - Parte B

\begin{tabular}{|c|c|c|c|c|c|c|}
\hline & \multicolumn{2}{|c|}{ KS MQO } & \multicolumn{2}{|c|}{ Marginal } & \multicolumn{2}{|c|}{ Jones FL ${ }^{69}$} \\
\hline & coeficiente & $p$-value & coeficiente & p-value & Coeficiente & p-value \\
\hline Constante & $-0,036$ & 0,046 & $-0,041$ & 0,002 & $-0,003$ & 0,874 \\
\hline $\mathrm{R}_{\mathrm{it}}$ & $-0,004$ & 0,931 & 0,570 & 0,000 & & \\
\hline $\mathrm{D}_{\mathrm{it}}$ & 0,027 & 0,556 & & & & \\
\hline $\begin{array}{l}P E_{i t} \\
R_{i t}-\Delta \mathrm{CR}_{i t}\end{array}$ & $-0,031$ & 0,091 & -0.577 & 0,000 & $-0,034$ & 0,061 \\
\hline$(1+\mathrm{k}) \Delta \mathrm{R}_{\mathrm{it}}-\Delta \mathrm{CR}_{\mathrm{it}}$ & & & & & 0,063 & 0,215 \\
\hline $\mathrm{TA}_{\mathrm{it}-1}$ & & & & & 0,108 & 0,250 \\
\hline $\mathrm{CrR}_{\mathrm{it}+1}$ & & & & & 0,008 & \\
\hline$R^{2}$ & 0,045 & & 0,134 & & 0,061 & \\
\hline$R^{2}$ ajustado & 0,038 & & 0,126 & & 0,048 & \\
\hline Akaike criterion & $-0,427$ & & $-0,523$ & & $-0,536$ & \\
\hline Schwarz criterion & $-0,367$ & & $-0,465$ & & $-0,458$ & \\
\hline Estatística $F$ & 5,057 & 0,000 & 16,486 & 0,000 & 4,892 & 0,000 \\
\hline White Heteros & & & & & & \\
\hline Test & 515,949 & 0,000 & 263,927 & 0,102 & 1311,446 & 0,000 \\
\hline KB Test & 2,573 & 0,000 & 0,223 & 0,030 & 13,094 & 0,000 \\
\hline Durbin-Watson & 1,613 & & 1,545 & & 1,966 & \\
\hline Breusch-Godfrey Serial & & & & & & \\
\hline Correlation LM Test & 84,504 & 0,000 & 107,369 & 0,000 & 17,470 & 0,000 \\
\hline Jarque-Bera Test & 297400 & 0,000 & 392850 & 0,000 & 268313 & 0,000 \\
\hline Observações & 3014 & & 3013 & & 2210 & \\
\hline
\end{tabular}

Para verificar se a utilização do método VI auxilia na especificação dos modelos, foram estimados os mesmos parâmetros do modelo KS pelo método dos Mínimos Quadrados Ordinários (KS MQO). Conforme consta da Tabela 18, o modelo KS MQO, no contexto brasileiro, apresenta $\beta$ 's a zero $(\beta=0)$, problemas de correlação serial dos resíduos e heteroscedasticidade, além do $R^{2}$ ajustado decrescer, o que evidencia que o modelo $\mathrm{KS}$ estimado pela abordagem VI é mais adequado do que pelo método MQO. Assim como no modelo KS estimado por meio VI, as variáveis dummies para os setores de construção $(0,051)$, telecomunicação $(-0,074)$ e veículos e peças $(-0,066)$ têm coeficientes significativamente diferentes de zero, além da energia elétrica $(0,032)$.

No modelo Marginal, os parâmetros das variáveis são significativos na análise dos accruals totais, o que eleva o grau de ajustamento $\left(R^{2}=0,134\right)$, porém continua apresentando correlação serial, mas pelo teste de White, os resíduos são homoscedásticos. Para o modelo Marginal, as variáveis dummies dos setores econômicos que têm coeficientes significativos são a da construção $(0,052)$, telecomunicação $(-0,101)$ e veículos e peças $(-0,056)$.

\footnotetext{
${ }^{69}$ A abreviatura 'Jones FL' significa 'Jones Forward Looking'.
} 
O modelo Jones Forward Looking (Jones FL) apresenta os mesmos problemas do modelo Jones original, heteroscedasticidade e autocorrelação, mas todos os seus $\beta$ 's são estatisticamente iguais a zero, o que reduz o seu poder preditivo $\left(R^{2}\right.$ ajustado $\left.=0,048\right)$, evidenciando que esse modelo não tem melhor grau de ajustamento do que seu antecessor $\left(R^{2}\right.$ ajustado $\left.=0,061\right)$.

Considerando os resultados observados pelos modelos anteriores, o modelo Pae (2005) apresenta um melhor grau de ajustamento $\left(R^{2}=0,214\right)$, porém com problema de heteroscedasticidade, mas os seus resíduos não são autocorrelacionados. A estimativa da variável 'fluxo de caixa operacional defasado' $\left(F C O_{i t-1}\right)$ não é significativamente diferente de zero ( $p$-value $=0,084)$, devido à forte correlação existente com o fluxo de caixa operacional corrente $\left(F C O_{i t}\right)$, também incluída nesse modelo. Como esperado, a inclusão da variável 'accruals totais defasados' $\left(T A_{i t-1}\right)$, que representa a reversão natural dos accruals, reduziu o problema de correlação serial existente nos modelos anteriores, conforme observado pelos testes Durbin-Watson e Breusch-Godfrey Serial Correlation LM.

Tanto para o modelo Jones Forward Looking, quanto para o modelo Pae, o único coeficiente significativo de setor é o de telecomunicações, com estimativas de $-0,077$ e $-0,040$, respectivamente.

Como em todos os modelos, exceto pelo modelo proposto neste trabalho, o coeficiente para o setor de telecomunicações foi significativamente negativo, assim, pode-se considerar que as empresas desse setor econômico, no contexto brasileiro, têm, em média, um menor volume de accruals líquidos.

Para explorar algumas alternativas de especificação de modelos, foram estimados os parâmetros e os testes para o modelo proposto com ou sem variáveis explicativas, com o objetivo de verificar se efetivamente o gerenciamento de resultados por meio das atividades operacionais afeta o comportamento dos accruals totais. Em ambos os casos, os testes específicos sobre o modelo proposto evidenciam a presença de heteroscedasticidade e autocorrelação.

$\mathrm{Na}$ especificação com as proxies de gerenciamento das atividades operacionais, os coeficientes das variáveis 'ativo imobilizado' $\left(A I_{t}\right)$, 'ativo diferido' $\left(A D_{i t}\right)$, fluxo de caixa operacional corrente $\left(F C O_{i t}\right)$ e 'accruals totais defasados' $\left(T A_{i t-1}\right)$ não são significativamente diferentes de zero, considerando-se um nível de significância de 5\%. Além dessas variáveis, as proxies utilizadas para captar a influência do nível de conservadorismo e do gerenciamento das atividades operacionais, excetuando-se as variáveis $\triangle E_{t-1}$ e $A b_{-} C F O_{i t}$, também não apresentaram coeficientes estatisticamente diferentes de zero. 
Tabela 19 - Estimação dos modelos operacionais no contexto brasileiro - Parte C

\begin{tabular}{|c|c|c|c|c|c|c|}
\hline & \multicolumn{2}{|c|}{ Pae } & \multicolumn{2}{|c|}{ Proposto } & \multicolumn{2}{|c|}{ Proposto (sem RM) ${ }^{70}$} \\
\hline & coeficiente & p-value & coeficiente & p-value & coeficiente & p-value \\
\hline Constante & & & 0,050 & 0,012 & 0,017 & 0,339 \\
\hline $1 / \mathrm{A}_{\mathrm{it}-1}$ & $-5,543$ & 0,048 & & & & \\
\hline$\Delta \mathrm{R}_{\mathrm{it}}$ & 0,099 & 0,004 & & & & \\
\hline $\mathrm{PPE}_{\mathrm{it}}$ & $-0,034$ & 0,043 & & & & \\
\hline $\mathrm{FCO}_{\text {it }}$ & $-0,274$ & 0,003 & $-3,909$ & 0,196 & $-0,348$ & 0,000 \\
\hline $\mathrm{FCO}_{\text {it-1 }}$ & 0,103 & 0,084 & & & & \\
\hline $\mathrm{TA}_{\mathrm{it}-1}$ & 0,221 & 0,006 & 0,080 & 0,128 & 0,122 & 0,094 \\
\hline $\mathrm{R}_{\text {it }}$ & & & 0,470 & 0,001 & 0,520 & 0,000 \\
\hline $\mathrm{CD}_{\text {it }}$ & & & $-0,419$ & 0,004 & $-0,521$ & 0,001 \\
\hline $\mathrm{AI}_{\mathrm{it}}$ & & & $-0,010$ & 0,532 & $-0,022$ & 0,201 \\
\hline $\mathrm{AD}_{\text {it }}$ & & & $-0,006$ & 0,895 & $-0,026$ & 0,510 \\
\hline $\mathrm{E}_{\mathrm{it}}$ & & & 0,294 & 0,000 & 0,107 & 0,075 \\
\hline$E_{i t}^{2}$ & & & 0,031 & 0,001 & 0,016 & 0,000 \\
\hline$\Delta \mathrm{E}_{\mathrm{t}-1}$ & & & $-0,063$ & 0,000 & $-0,023$ & 0,006 \\
\hline $\mathrm{D} \Delta \mathrm{E}_{\mathrm{it}-1}$ & & & $-0,014$ & 0,271 & $-0,003$ & 0,704 \\
\hline$\Delta \mathrm{E}_{\mathrm{it}-1}{ }^{*} \mathrm{D} \Delta \mathrm{E}_{\mathrm{it}-1}$ & & & $-0,237$ & 0,213 & $-0,028$ & 0,385 \\
\hline Ab_Prod ${ }_{i t}$ & & & 4,557 & 0,137 & & \\
\hline $\mathrm{Ab} \_\mathrm{DO}_{\mathrm{it}}$ & & & $-0,028$ & 0,060 & & \\
\hline $\mathrm{Ab}_{-} \mathrm{CFO}_{\text {it }}$ & & & $-1,143$ & 0,001 & & \\
\hline$R^{2}$ & 0,214 & & 0,400 & & 0,316 & \\
\hline$R^{2}$ ajustado & 0,205 & & 0,390 & & 0,306 & \\
\hline Akaike criterion & $-0,602$ & & $-0,886$ & & $-0,736$ & \\
\hline Schwarz criterion & $-0,531$ & & $-0,789$ & & $-0,653$ & \\
\hline Estatística $F$ & & & 40,449 & 0,000 & 32,928 & 0,000 \\
\hline White Heteroskedasticity & & & & & & \\
\hline Test & 2113,037 & 0,000 & 1280,950 & 0,000 & 2522,814 & 0,000 \\
\hline KB Test & 1,088 & 0,000 & 0,757 & 0,000 & 0,739 & 0,000 \\
\hline Durbin-Watson & 1,930 & & 1,745 & & 1,774 & \\
\hline Breusch-Godfrey Serial & & & & & & \\
\hline Correlation LM Test & 1,858 & 0,395 & 50,765 & 0,000 & 28,549 & 0,000 \\
\hline Jarque-Bera Test & 227309 & 0,000 & 391920 & 0,000 & 305480 & 0,000 \\
\hline Observações & 2673 & & 2464 & & 2674 & \\
\hline
\end{tabular}

As variáveis $T A_{i t-1}$ e $A b_{-} D O_{i t}$ tiveram sinais diferentes do esperados, mas não significativamente diferente de zero. No modelo proposto, os coeficientes das dummies para os setores econômico não foram significativos.

Apesar dessas observações, esse modelo tem um acréscimo significativo no grau de ajustamento $\left(R^{2}=0,400\right)$ em relação aos modelos concorrentes, mostrando ser o modelo de maior predição do comportamento dos accruals totais.

Em seguida, foi estimado o modelo proposto sem a inclusão das variáveis para controlar a manipulação das atividades reais. Observou-se que o grau de ajustamento do modelo teve uma redução considerável, pois o $R^{2}$ ajustado passou de 0,390 para 0,306 e a estimação de $\beta$

\footnotetext{
${ }^{70}$ A abreviatura 'sem RM' significa 'sem as proxies de manipulação das atividades operacionais'.
} 
da variável $E_{t}$ torna-se igual a zero, enquanto a variável $F C O_{i t}$ passou a ser significativamente diferente de zero.

Adicionalmente, na Tabela 20, são apresentadas as estimações dos parâmetros e dos testes estatísticos para as proxies de gerenciamento das atividades operacionais utilizadas no modelo proposto (descritos na seção 3.5). Observe-se que todas as regressões têm presença de heteroscedasticidade e de autocorrelação (exceto o modelo das despesas operacionais). O poder preditivo da estimação da produção $\left(R^{2}=0,953\right)$ e o do fluxo de caixa operacional $\left(R^{2}=\right.$ $0,639)$ podem ser considerados satisfatórios.

Tabela 20 - Gerenciamento de atividades operacionais no contexto brasileiro

\begin{tabular}{|c|c|c|c|c|c|c|}
\hline & \multicolumn{2}{|c|}{ Produção } & \multicolumn{2}{|c|}{ Despesa Operacional } & \multicolumn{2}{|c|}{$\begin{array}{l}\text { Fluxo de Caixa } \\
\text { Operacional }\end{array}$} \\
\hline & coeficiente & p-value & coeficiente & p-value & coeficiente & p-value \\
\hline Constante & 0,122 & 0,000 & 0,078 & 0,001 & & \\
\hline $1 / A_{\text {it- } 1}$ & 0,286 & 0,000 & & & $-31,373$ & 0,000 \\
\hline $\mathrm{R}_{\mathrm{it}}$ & 0,847 & 0,000 & 0,158 & 0,000 & 0,020 & 0,027 \\
\hline$\Delta \mathrm{R}_{\mathrm{it}}$ & $-0,083$ & 0,000 & & & $-0,017$ & 0,644 \\
\hline$\Delta \mathrm{R}_{\mathrm{it}-1}$ & $-0,003$ & 0,869 & & & & \\
\hline $\mathrm{R}_{\mathrm{it} *} \mathrm{D}_{\mathrm{it}}$ & & & 0,624 & 0,020 & & \\
\hline $\mathrm{R}_{\mathrm{it}-1}$ & & & $-0,126$ & 0,000 & & \\
\hline $\mathrm{R}_{\mathrm{it}-1} * \mathrm{D}_{\mathrm{it}-1}$ & & & 0,010 & 0,710 & & \\
\hline$R^{2}$ & 0,953 & & 0,118 & & 0,639 & \\
\hline$R^{2}$ ajustado & 0,952 & & 0,112 & & 0,637 & \\
\hline Akaike criterion & $-1,038$ & & 0,775 & & 0,105 & \\
\hline Schwarz criterion & $-0,993$ & & 0,822 & & 0,143 & \\
\hline Estatística $F$ & 2826,998 & 0,000 & 17,300 & 0,000 & & \\
\hline $\begin{array}{l}\text { Durbin-Watson } \\
\text { White Heteroskedasticity }\end{array}$ & 0,446 & & 1,881 & & 1,680 & \\
\hline $\begin{array}{l}\text { Test } \\
\text { Breusch-Godfrey Serial }\end{array}$ & 1299,611 & 0,000 & 387,622 & 0,000 & 571,701 & 0,000 \\
\hline Correlation LM Test & 1577,786 & 0,000 & 3,612 & 0,164 & 81,644 & 0,000 \\
\hline Jarque-Bera Test & 5393,418 & 0,000 & 45904,540 & 0,000 & 5941484 & 0,000 \\
\hline Observações & 2942 & & 2718 & & 3240 & \\
\hline
\end{tabular}

O teste Variance Inflation Factor para todos os modelos de estimação dos accruals, analisados neste trabalho, é apresentado na Tabela $21^{71}$. Constata-se que os modelos, excetuando-se o Marginal e o Proposto, não possuem problemas de multicolineariedade na especificação, pois para essa estatística os valores estimados estão próximos de 1 .

Com relação ao modelo Marginal, a multicolinearidade é devida à forte correlação (maior que $0,90)$ entre as duas variáveis explicativas. O modelo proposto apresenta multicolinearidade nas variáveis $R_{i t}, F C O_{i t}, C D_{i t}$ e $A b_{-} C F O_{i t}$. As variáveis $R_{i t}$ e $C D_{i t}$ possuem uma correlação acima de 0,900, enquanto a variável $F C O_{i t}$ tem alta correlação com $A b_{-} C F O_{i t}$, além de

\footnotetext{
${ }^{71}$ Esse teste não foi efetuado para o modelo Setorial, pois ele utiliza somente uma variável explicativa, portanto, não tem problema com multicolineariedade.
} 
correlação significativa com as variáveis $E_{i t}$ e $A b_{-} \operatorname{Prod}_{i t}$ (conforme apresentado nos Apêndices 1 e 2).

Tabela 21 - Teste de multicolineariedade Variance Inflation Factor no contexto brasileiro

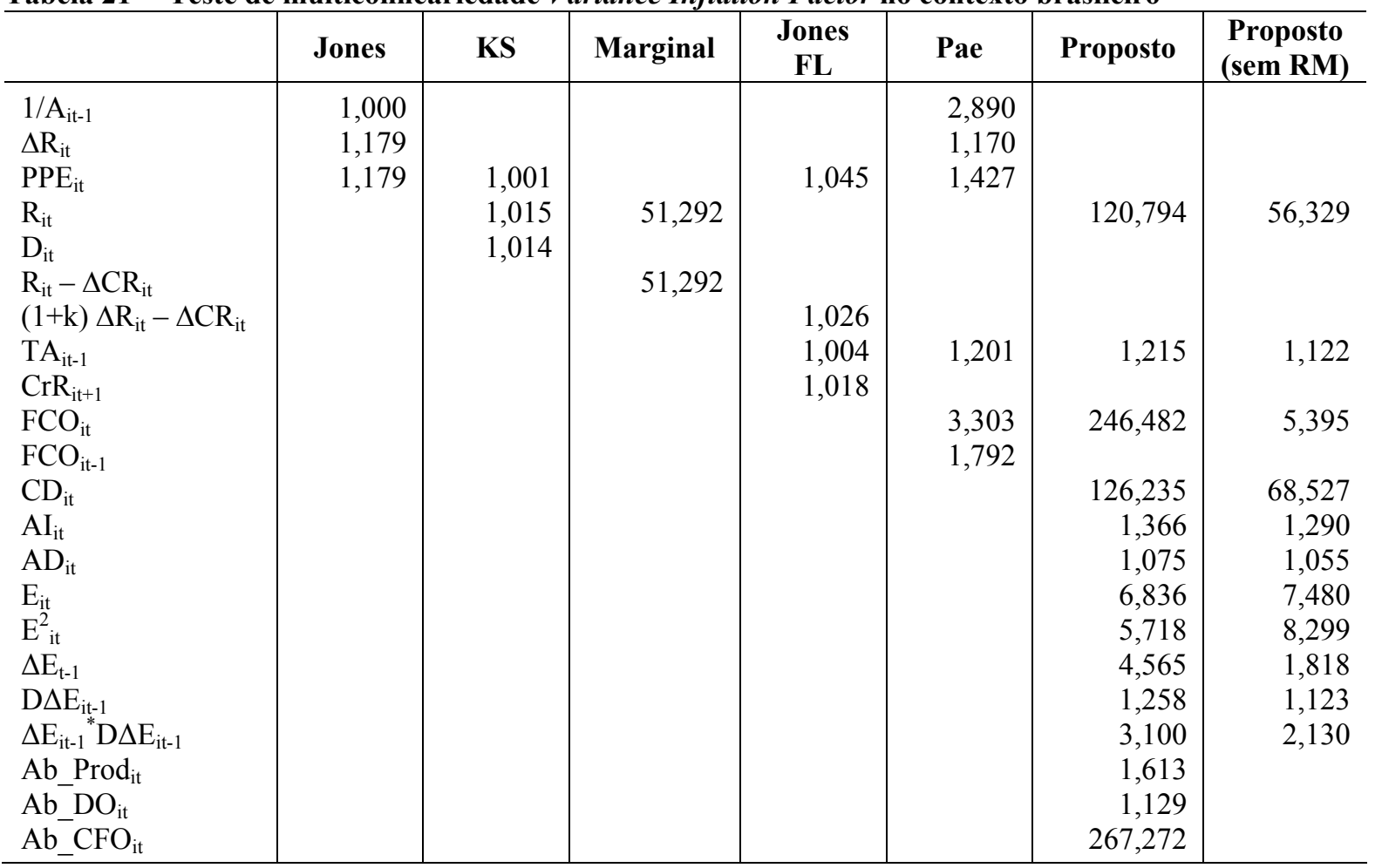

Buscando reduzir o número de variáveis para descrever o comportamento dos accruals no contexto brasileiro, efetuou-se a análise fatorial exploratória com o intuito de identificar fatores e solucionar problemas de multicolineariedade. Porém, conforme apresentado na Tabela 22, a utilização dessa técnica não é satisfatória, pois o teste de Kaiser-Meyer-Olkin - KMO (Measure of Sampling Adequacy - MSA) indica um grau de explicação de 0,484 sendo menor que 0,500 , portanto, os fatores encontrados pela análise fatorial não descrevem adequadamente as variações das variáveis originais, ou seja, a aplicação da análise fatorial não é recomendada nesse caso (TABACHNICK; FIDELL, 2001, p.589; HAIR JR et al, 2005, p.98; PESTANA; GAGEIRO, 2005, p.491).

Analisando-se a Correlação da Matriz Anti-Imagem (Apêndice 28), verifica-se que a maioria das variáveis têm MSA inferiores a 0,50. Essas estimativas do MSA são consideradas baixas e, portanto, essas variáveis devem ser retiradas da Análise Fatorial, o que impossibilita a utilização dessa técnica. Portanto, a Análise Fatorial, no contexto brasileiro, não é adequada para criar fatores que expliquem o comportamento dos accruals. 
Tabela 22 - KMO and Bartlett's Test - Brasil

\begin{tabular}{|c|c|c|}
\hline & este & coeficiente \\
\hline \multicolumn{2}{|c|}{ Kaiser-Meyer-Olkin Measure of Sampling Adequacy. } & 0,484 \\
\hline \multirow[t]{3}{*}{ Bartlett's Test of Sphericity } & Approx. Chi-Square & 31692,989 \\
\hline & df & 91 \\
\hline & Sig. & 0,000 \\
\hline
\end{tabular}

Como observado no Capítulo 4 (Procedimentos Metodológicos), avaliar o grau de ajuste dos modelos pelo $R^{2}$ ajustado é inadequado, pois essa estatística pode ser enviesada quando a especificação do modelo não contém o termo constante, o que ocorre no modelo Jones e suas variantes. Outros testes estatísticos, para avaliar a especificação, podem ser utilizados, como, por exemplo, Critério de Informação de Akaike (AIC) e Critério de Schwarz. Entretanto, a comparação do grau de ajustamento entre os modelos com base nessas estatísticas deve ser feita com cautela, como observado por Pindyck e Rubinfeld (2004, p.275).

Como pode ser verificado, o modelo proposto apresenta o melhor grau de ajustamento da curva, seguido do modelo proposto sem as proxies do gerenciamento de atividades operacionais. Excetuando-se o modelo Pae, as demais propostas têm poder explicativo baixo dentro do contexto das companhias abertas brasileiras.

Tabela 23 - Comparação do ajuste dos modelos operacionais no contexto brasileiro

\begin{tabular}{l|r|r|r}
\hline \multicolumn{1}{c|}{ Modelos } & $\mathbf{R}^{2}$ ajustado & Akaike & Schwarz \\
\hline Setorial & 0,027 & $-0,424$ & $-0,402$ \\
Jones & 0,061 & $-0,452$ & $-0,394$ \\
KS & 0,057 & $-0,553$ & $-0,553$ \\
KS MQO & 0,038 & $-0,427$ & $-0,367$ \\
Marginal & 0,124 & $-0,523$ & $-0,465$ \\
Jones FL & 0,048 & $-0,536$ & $-0,458$ \\
Pae & 0,205 & $-0,602$ & $-0,531$ \\
Proposto & 0,390 & $-0,886$ & $-0,789$ \\
Proposto (sem RM) & 0,306 & $-0,736$ & $-0,653$ \\
\hline
\end{tabular}

Adicionalmente, observe-se que o modelo Jones Forward Looking tem menor $R^{2}$ e $R^{2}$ ajustado (respectivamente, 0,061 e 0,048$)$ do que o seu antecessor, o modelo Jones $\left(R^{2}=0,070\right.$ e $R^{2}$ ajustado=0,061). Essa evidência comprova que os modelos que não apresentam o termo constante na especificação podem ser enviesados, porque a adição de qualquer variável explicativa (mesmo quando irrelevante) não diminui o $R^{2}$ em relação ao modelo anterior (considerado modelo restrito). Mas, com base no teste Vuong para modelos non-nested (Tabela 24), o modelo Jones Forward Looking teve maior poder preditivo do que o modelo Jones, corroborando a teoria subjacente. 
Tanto pelo $R^{2}$ ajustado, Critério de Akaike e Critério de Schwarz, quanto pelo teste Vuong, o modelo KS apresentou maior poder preditivo quando estimado pelo método IV do que pelo MQO, apesar da baixa correlação entre as variáveis explicativas e suas respectivas variáveis instrumentais.

Tabela 24 - Comparação dos modelos operacionais no contexto brasileiro - Teste Vuong

\begin{tabular}{|c|c|c|c|c|c|c|c|c|}
\hline Modelo & Setorial & Jones & KS & $\begin{array}{c}\text { KS } \\
\text { MQO }\end{array}$ & $\begin{array}{c}\text { Margi- } \\
\text { nal }\end{array}$ & $\begin{array}{c}\text { Jones } \\
\text { FL }\end{array}$ & Pae & $\begin{array}{c}\text { Propos- } \\
\text { to }\end{array}$ \\
\hline Jones & $\begin{array}{c}\text { 6,954 } \\
\text { Jones }\end{array}$ & & & & & & & \\
\hline $\mathrm{KS}$ & $\begin{array}{l}17,942 \\
\mathrm{KS}\end{array}$ & $\begin{array}{l}12,266 \\
\mathrm{KS}\end{array}$ & & & & & & \\
\hline KS MQO & $\begin{array}{c}-7,930 \\
\text { Setorial } \\
\end{array}$ & $\begin{array}{l}-18,465 \\
\text { Jones }\end{array}$ & $\begin{array}{c}-24,091 \\
\mathrm{KS}\end{array}$ & & & & & \\
\hline Marginal & $\begin{array}{r}2,569 \\
\text { Marginal } \\
\end{array}$ & $\begin{array}{l}-2,631 \\
\text { Jones }\end{array}$ & $\begin{array}{c}-10,570 \\
\mathrm{KS}\end{array}$ & $\begin{array}{r}6,655 \\
\text { Marginal } \\
\end{array}$ & & & & \\
\hline JonesFl & $\begin{array}{r}20,445 \\
\text { JonesFl }\end{array}$ & $\begin{array}{r}19,307 \\
\text { JonesFl }\end{array}$ & $\begin{array}{r}17,812 \\
\text { JonesFl }\end{array}$ & $\begin{array}{r}24,661 \\
\text { JonesFl }\end{array}$ & $\begin{array}{r}17,286 \\
\text { JonesF1 }\end{array}$ & & & \\
\hline $\mathrm{Pae}$ & $\begin{array}{l}16,025 \\
\text { Pae }\end{array}$ & $\begin{array}{l}13,453 \\
\text { Pae }\end{array}$ & $\begin{array}{l}6,031 \\
\mathrm{Pae}\end{array}$ & $\begin{array}{l}19,078 \\
\mathrm{Pae}\end{array}$ & $\begin{array}{l}14,905 \\
\mathrm{Pae}\end{array}$ & $\begin{array}{c}-5,004 \\
\text { JonesFl }\end{array}$ & & \\
\hline Proposto & $\begin{array}{r}13,990 \\
\text { Proposto } \\
\end{array}$ & $\begin{array}{r}12,412 \\
\text { Proposto } \\
\end{array}$ & $\begin{array}{r}9,127 \\
\text { Proposto } \\
\end{array}$ & $\begin{array}{r}15,130 \\
\text { Proposto } \\
\end{array}$ & $\begin{array}{r}13,849 \\
\text { Proposto } \\
\end{array}$ & $\begin{array}{r}2,975 \\
\text { Proposto } \\
\end{array}$ & $\begin{array}{r}7,743 \\
\text { Proposto } \\
\end{array}$ & \\
\hline $\begin{array}{l}\text { Proposto } \\
\text { sem RM }\end{array}$ & $\begin{array}{r}15,463 \\
\text { Proposto } \\
\text { sem RM }\end{array}$ & $\begin{array}{r}13,203 \\
\text { Proposto } \\
\text { sem RM }\end{array}$ & $\begin{array}{r}10,180 \\
\text { Proposto } \\
\text { sem RM }\end{array}$ & $\begin{array}{r}18,071 \\
\text { Proposto } \\
\text { sem RM }\end{array}$ & $\begin{array}{r}14,758 \\
\text { Proposto } \\
\text { sem RM }\end{array}$ & $\begin{array}{c}1,364 \\
\text { Indife- } \\
\text { rente }\end{array}$ & $\begin{array}{r}3,999 \\
\text { Proposto } \\
\text { sem RM } \\
\end{array}$ & $\begin{array}{r}-6,459 \\
\text { Proposto }\end{array}$ \\
\hline
\end{tabular}

Por fim, com base nas estatísticas apresentadas na Tabela 23 e, especialmente, pelo teste Vuong (Tabela 24), o modelo proposto tem a melhor especificação para a predição do comportamento dos accruals no contexto das companhias abertas brasileiras. Observe-se, também, que o modelo especificado com as proxies de gerenciamento de resultados através das atividades operacionais tem maior poder preditivo do que o modelo sem a presença dessas variáveis.

Contudo, uma questão ainda fica em aberto: as variáveis que apresentam problemas de multicolineariedade são relevantes para o modelo proposto?

Para verificar a efetiva contribuição das proxies de gerenciamento das atividades operacionais ao modelo proposto, foram efetuados testes (isolados e conjuntos) de variáveis redundantes (log likelihood ratio), apresentados na Tabela 25. Verificou-se que a variável $A b_{-} C F O_{i t}$ é irrelevante no contexto brasileiro, podendo ser extraída do modelo originalmente descrito, nesse caso o $R^{2}$ ajustado não seria reduzido $(0,390)$, porém a estimação continua com presença de heteroscedasticidade e correlação serial. Por outro lado, a retirada da variável $A b_{-} C F O_{i t}$ elimina o problema de multicolineariedade da variável $C F O_{i t}$, sendo que ela passa a 
ter coeficiente significativo. As demais variáveis do modelos não sofrem alterações significativas nos estimadores dos $\beta$ 's.

Para uma melhor especificação do modelo deve-se analisar essa variável em outras amostras e, então, verificar se ela é ou não uma variável relevante.

Tabela 25 - Testes de variáveis redundantes para as proxies de gerenciamento de atividades operacionais - Brasil

\begin{tabular}{|c|c|c|}
\hline & \multicolumn{2}{|c|}{ log likelihood ratio } \\
\hline & Coeficiente & p-value \\
\hline Ab_Prod ${ }_{i t}$ & 9,849 & 0,002 \\
\hline $\mathrm{Ab}_{-} \mathrm{DO}_{\text {it }}$ & 7,820 & 0,005 \\
\hline $\mathrm{Ab}_{-} \mathrm{CFO}_{\text {it }}$ & 1,445 & 0,229 \\
\hline $\mathrm{Ab}{ }_{-} \operatorname{Prod}_{\mathrm{it}} \mathrm{Ab} \mathrm{DO}_{\mathrm{it}}$ & 14,947 & 0,001 \\
\hline $\mathrm{Ab}{ }_{-}^{-} \operatorname{Prod}_{\mathrm{it}} \mathrm{Ab}{ }_{-}^{-} \mathrm{CFO}_{\mathrm{it}}$ & 14,663 & 0,001 \\
\hline $\mathrm{Ab}_{-} \mathrm{DO}_{\mathrm{it}} \mathrm{Ab} \mathrm{C}_{-} \mathrm{C} F \mathrm{O}_{\mathrm{it}}$ & 9,435 & 0,009 \\
\hline $\mathrm{Ab}_{-} \operatorname{Prod}_{i t} \quad \mathrm{~A} \bar{b} \_\mathrm{DO}_{\text {it }} \quad \mathrm{Ab}_{-} \mathrm{CFO}_{\text {it }}$ & 17,501 & 0,001 \\
\hline
\end{tabular}

Da mesma forma, com o intuito de analisar a contribuição da proxy do nível de conservadorismo, foram efetuados os testes (isolados e conjuntos) de variáveis redundantes para as variáveis $\Delta E_{t-1}, D \Delta E_{i t-1}$ e $\Delta E_{i t-1}{ }^{*} D \Delta E_{i t-1}$, apresentados na Tabela 26. Observe-se que existem evidências de que elas são variáveis relevantes. Portanto, verifica-se que o conjunto dessas variáveis, que formam o modelo de conservadorismo proposto por Ball e Shivakumar (2005), é considerado relevante para o modelo proposto na predição do comportamento dos accruals no contexto brasileiro.

Essa evidência sugere que o nível de conservadorismo influencia a estimação dos accruals não-discricionários e discricionários, conforme descrito na suposição 9.

Tabela 26 - Testes de variáveis redundantes para as proxies de conservadorismo - Brasil

\begin{tabular}{|c|c|c|}
\hline & \multicolumn{2}{|c|}{ log likelihood ratio } \\
\hline & Coeficiente & p-value \\
\hline$\Delta \mathrm{E}_{\mathrm{t}-1}$ & 215,978 & 0,000 \\
\hline $\mathrm{D} \Delta \mathrm{E}_{\mathrm{it}-1}$ & 4,220 & 0,040 \\
\hline$\Delta \mathrm{E}_{\mathrm{it}-1}{ }^{*} \mathrm{D} \Delta \mathrm{E}_{\mathrm{it}-1}$ & 60,639 & 0,000 \\
\hline $\mathrm{D} \Delta \mathrm{E}_{\mathrm{it}-1}$ & 224,783 & 0,000 \\
\hline$\Delta \mathrm{E}_{\mathrm{it}-1}^{*} \mathrm{D} \Delta \mathrm{E}_{\mathrm{it}-1}$ & 313,616 & 0,000 \\
\hline $\mathrm{D} \Delta \mathrm{E}_{\mathrm{it}-1} \Delta \mathrm{E}_{\mathrm{it}-1}{ }^{*} \mathrm{D} \Delta \mathrm{E}_{\mathrm{it}-1}$ & 60,684 & 0,000 \\
\hline$\Delta \mathrm{E}_{\mathrm{t}-1} \quad \mathrm{D} \Delta \mathrm{E}_{\mathrm{it}-1} \quad \Delta \mathrm{E}_{\mathrm{it}-1}{ }^{*} \mathrm{D} \Delta \mathrm{E}_{\mathrm{it}-1}$ & 314,104 & 0,000 \\
\hline
\end{tabular}

Além dessas, foram testadas as outras variáveis que apresentam problemas de multicolinearidade. Com base nos testes de variáveis redundantes (log likelihood ratio), verificou-se que as variáveis $R_{i t}$ e $C D_{i t}$ são relevantes, pois suas estimativas foram de 139,038 $(p$-value $=0,000)$ e 103,679 $(p$-value $=0,000)$, respectivamente. O modelo sem a 
especificação da variável $R_{i t}$ continua apresentando problemas de multicolineariedade nas demais variáveis $\left(F C O_{i t}, C D_{i t}\right.$ e $\left.A b_{-} C F O_{i t}\right)$ e teria um $R^{2}$ ajustado igual a 0,355 . No caso de se extrair a variável $C D_{i t}$, os problemas de especificação continuariam os mesmos encontrados na especificação original, porém haveria uma grande redução do $\operatorname{VIF}(12,956)$ para a variável $R_{i t}$, mas fora do nível adequado. Segundo Gujarati (2006, p.292), para ser um nível aceitável de multicolineariedade, o VIF deve ser menor que 10,00.

Por outro lado, a variável $F C O_{i t}$ é relevante para o modelo, pois, no teste de variáveis redundantes, a estimativa é de 21,649 ( $p$-value $=0,000)$. Existe uma forte correlação entre ela e a proxy para comportamento anormal dos fluxos de caixa operacionais $\left(A b_{-} C F O_{i t}\right)$ que detecta o gerenciamento das atividades operacionais. Como apresentado na Tabela 25, a variável $A b_{-} C F O_{i t}$ é irrelevante no contexto brasileiro, assim pode-se considerar que a variável $A b_{-} C F O_{i t}$ pode ser extraída do modelo original.

Então, no caso de as variáveis $A b_{-} C F O_{i t}$ e $C D_{i t}$ serem extraídas da especificação, o modelo não apresentará problemas de multicolinearidade em nenhuma das variáveis explicativas (inclusive para $R_{i t}$ ) ) o $R^{2}$ ajustado passará a ser de 0,364 (contra um $R^{2}$ ajustado de 0,390 do modelo originalmente proposto).

Adicionalmente, foi testada a relevância das variáveis $A I_{i t}\left(\mathrm{p}\right.$-value=0,414) e $A D_{i t}$ ( $p$-value $=0,888)$ e se constatou que não são significantes para o modelo proposto.

Porém todas as observações sobre a relevância ou não das variáveis originais no modelo proposto devem ser verificadas novamente nas amostras dos demais países analisados.

O grau de ajustamento do modelo proposto, também é superior aos modelos concorrentes, quando estimados por meio de dados em painel, conforme demostrado na Tabela 27. Essa evidência é corroborada pela estimação por cross section para cada ano da amostra (Apêndices 29 a 36). Portanto, independentemente do método de estimação dos modelos operacionais, no contexto brasileiro, o modelo proposto apresentou melhor poder preditivo para a análise do comportamento dos accruals.

Adicionalmente, no contexto brasileiro, observa-se que a estimação dos modelos com dados em painel não apresenta um aumento significativo do poder preditivo dos modelos, particularmente, do modelo proposto neste trabalho. Mas, comparações entre os métodos de estimações devem ser feitos com cautela, pois as variâncias das variáveis se alteram conforme o modelo de estimação empregado, portanto, as estimativas dos parâmetros e os testes de significância medem coisas diferentes. 
Tabela 27 - Grau de ajustamento ( $R^{2}$ ajustado) dos modelos com dados em painel no contexto brasileiro

\begin{tabular}{l|c|c|c|c}
\hline \multicolumn{1}{c|}{ Modelo } & $\begin{array}{c}\text { Intercepto } \\
\text { comum }\end{array}$ & $\begin{array}{c}\text { Efeitos } \\
\text { fixos }\end{array}$ & $\begin{array}{c}\text { Efeitos } \\
\text { aleatórios }\end{array}$ & Modelo preferível $^{\mathbf{7 2}}$ \\
\hline Setorial & 0,027 & 0,069 & 0,136 & Efeitos fixos \\
Jones & 0,050 & 0,111 & 0,173 & Efeitos fixos \\
KS & 0,028 & 0,076 & 0,120 & Efeitos fixos \\
Marginal & 0,118 & 0,198 & 0,254 & Efeitos aleatórios \\
Jones FL & 0,025 & 0,081 & 0,120 & Efeitos aleatórios \\
Pae & 0,167 & 0,230 & 0,279 & Efeitos aleatórios \\
Proposto & 0,359 & 0,399 & 0,442 & Efeitos aleatórios \\
Proposto (sem RM) & 0,281 & 0,355 & 0,405 & Efeitos aleatórios \\
\hline
\end{tabular}

A simulação de Monte Carlo foi outro método empregado com o objetivo de verificar a especificação e o poder estatístico dos modelos analisados neste trabalho, por meio da análise da freqüência em que ocorre o Erro do Tipo I e Erro do Tipo II. Com base no Apêndice 45, excetuando-se os modelos Healy e Marginal, observa-se que os demais modelos de estimação de accruals contribuem adequadamente para detectar o gerenciamento de resultados, pois o percentual de erros está próximo do nível de significância utilizado. Portanto, pode-se considerar que os modelos de estimação de accruals contribuem adequadamente para detecção do gerenciamento de resultados no contexto brasileiro.

\subsubsection{Chile}

Os testes para detectar a presença de heteroscedasticidade, correlação serial, normalidade e multicolineariedade foram os mesmos na amostra composta pelas companhias abertas brasileiras. Igualmente, foi constatado através do teste de Jarque-Bera que todos os modelos apresentam evidências de que os resíduos não são normalmente distribuídos.

De igual modo, verificou-se que todos os modelos, nesse ambiente econômico, atendem ao pressuposto da exogeneidade, pois não existe forte correlação entre os resíduos e as variáveis explicativas (Apêndices 1 e 2).

Conforme a Tabela 28, o modelo Setorial mostra problema de heteroscedasticidade (segundo o teste de White), mas sem a apresentar correlação serial nos resíduos. A estatística $F$ indica que a mediana setorial dos accruals totais não explica o comportamento dos accruals totais, conseqüentemente, o Coeficiente de Determinação $\left(R^{2}\right)$ é insignificante.

Com relação ao modelo Jones, observaram-se problemas de heteroscedasticidade e correlação serial (o teste Durbin-Watson indica que não existe autocorrelação), mas o $R^{2}$ é de 0,107

\footnotetext{
${ }^{72} \mathrm{O}$ procedimento de seleção do modelo com dados em painel é descrito na seção 4.5.
} 
(maior do que na amostra com as companhias brasileiras) e, conjuntamente com o teste $F$ Anova, indica que algumas das variáveis descrevem o comportamento dos accruals totais. Todavia, a única variável explicativa significativa para a variação dos accruals totais é a variável $P P E_{i t}$ (ativo imobilizado e diferido) e sinal como esperado. Não existe problema de multicolineariedade. Para esse modelo, os coeficientes da proxies para os setores de agropecuária e pesca $(\beta=0,063)$, construção $(\beta=0,088)$, energia elétrica $(\beta=0,047)$, papel e celulose $(\beta=0,071)$, química $(\beta=0,042)$ e transportes serviços $(\beta=0,044)$ foram significativos. Já o modelo KS estimado por meio do método de variáveis instrumentais tem baixo poder preditivo $\left(R^{2}=0,033\right)$, sendo que a única variável estatisticamente relevante é a receita $\left(R_{i t}\right)$. Esse modelo apresenta problemas de correlação serial e heteroscedasticidade, mas pelo teste de Koenker-Basset (teste KB) os dados são homoscedásticos. Conforme o teste FIV, não apresenta multicolineariedade entre as variáveis explicativas. As únicas variáveis setoriais significativas no modelo KS foram agropecuária e pesca $(\beta=0,028)$ e têxtil $(\beta=0,050)$.

Tabela 28 - Estimação dos modelos operacionais no contexto chileno - Parte A

\begin{tabular}{|c|c|c|c|c|c|c|}
\hline & \multicolumn{2}{|c|}{ Setorial } & \multicolumn{2}{|c|}{ Jones } & \multicolumn{2}{|c|}{$\mathbf{K S}$} \\
\hline & coeficiente & p-value & coeficiente & p-value & coeficiente & p-value \\
\hline Constante & 0,002 & 0,921 & & & $-0,039$ & 0,009 \\
\hline Mediana TA & 0,461 & 0,255 & & & & \\
\hline $1 / A_{\text {it- } 1}$ & & & 29630,120 & 0,114 & & \\
\hline$\Delta \mathrm{R}_{\mathrm{it}}$ & & & 0,025 & 0,326 & & \\
\hline $\mathrm{PPE}_{\mathrm{it}}$ & & & $-0,093$ & 0,000 & $-0,108$ & 0,373 \\
\hline $\mathrm{R}_{\mathrm{it}}$ & & & & & 0,110 & 0,000 \\
\hline $\mathrm{D}_{\mathrm{it}}$ & & & & & 0,045 & 0,313 \\
\hline$R^{2}$ & 0,008 & & 0,107 & & 0,033 & \\
\hline$R^{2}$ ajustado & 0,002 & & 0,093 & & 0,016 & \\
\hline Akaike criterion & $-0,439$ & & $-0,520$ & & $-0,642$ & \\
\hline Schwarz criterion & $-0,403$ & & $-0,433$ & & $-0,546$ & \\
\hline Estatística $F$ & 1,421 & 0,165 & & & 1,945 & 0,003 \\
\hline White Heteroskedasticity & & & & & & \\
\hline Test & 43,380 & 0,002 & 419,490 & 0,000 & 334,484 & 0,000 \\
\hline KB Test & $-3,581$ & 0,766 & 1,873 & 0,000 & 1,988 & 0,272 \\
\hline Durbin-Watson & 1,860 & & 1,992 & & 2,219 & \\
\hline Breusch-Godfrey Serial & & & & & & \\
\hline Correlation LM Test & 5,285 & 0,071 & 6,287 & 0,043 & 34,865 & 0,000 \\
\hline Jarque-Bera Test & 1372403 & 0,000 & 715767 & 0,000 & 1142183 & 0,000 \\
\hline Observações & 1695 & & 1686 & & 1569 & \\
\hline
\end{tabular}

Quando da estimação do modelo KS pelo método MQO, o $R^{2}$ ajustado passa a ser um pouco mais elevado, mas ainda com presença de heteroscedasticidade, porém sem autocorrelação. A única variável estatisticamente diferente de zero é a $P P E_{i t}$. Por essa estimação do modelo KS, agropecuária e pesca $(\beta=0,030)$, construção $(\beta=0,063)$ e papel e celulose $(\beta=0,007)$ são significativas estatisticamente. 
O modelo Marginal tem um $R^{2}$ de 0,027 e não possui presença de autocorrelação, mas seus resíduos são hetoroscedásticos conforme o teste de White. Adicionalmente, esse modelo apresenta correlação alta entre os seus dois regressores, o que causa problema de multicolineariedade. Os coeficientes das proxies para os setores de agropecuária e pesca $(\beta=0,040)$, construção $(\beta=0,078)$ e siderurgia e metalurgia $(\beta=0,031)$ são significativamente diferentes de zero na estimação do modelo Marginal na amostra com as companhias chilenas. Já o modelo Jones Forward Looking tem um poder preditivo menor que o Jones original e apresenta resíduos autocorrelacionados e heteroscedásticos. Igualmente ao modelo Jones, a única variável relevante, no modelo Jones Forward Looking, é a que representa o ativo imobilizado e diferido. Somente os coeficientes dos setores papel e celulose $(\beta=0,050)$ e têxtil $(\beta=-0,062)$ são significativos.

Tabela 29 - Estimação dos modelos operacionais no contexto chileno - Parte B

\begin{tabular}{|c|c|c|c|c|c|c|}
\hline & \multicolumn{2}{|c|}{ KS MQO } & \multicolumn{2}{|c|}{ Marginal } & \multicolumn{2}{|c|}{ Jones FL } \\
\hline & coeficiente & p-value & coeficiente & p-value & coeficiente & p-value \\
\hline Constante & 0,046 & 0,043 & $-0,028$ & 0,058 & 0,065 & 0,013 \\
\hline $\mathrm{R}_{\mathrm{it}}$ & $-0,084$ & 0,589 & 0,460 & 0,000 & & \\
\hline $\mathrm{D}_{\mathrm{it}}$ & 0,086 & 0,592 & & & & \\
\hline $\mathrm{PPE}_{\mathrm{it}}$ & $-0,095$ & 0,000 & & & $-0,136$ & 0,000 \\
\hline $\mathrm{R}_{\mathrm{it}}-\Delta \mathrm{CR}_{\mathrm{it}}$ & & & $-0,469$ & 0,000 & & \\
\hline$(1+\mathrm{k}) \Delta \mathrm{R}_{\mathrm{it}}-\Delta \mathrm{CR}_{\mathrm{it}}$ & & & & & 0,012 & 0,666 \\
\hline $\mathrm{TA}_{\mathrm{it}-1}$ & & & & & $-0,075$ & 0,054 \\
\hline $\mathrm{CrR}_{\mathrm{it}+1}$ & & & & & $-0,004$ & 0,076 \\
\hline$R^{2}$ & 0,042 & & 0,027 & & 0,063 & \\
\hline$R^{2}$ ajustado & 0,026 & & 0,012 & & 0,044 & \\
\hline Akaike criterion & $-0,449$ & & $-0,435$ & & $-0,634$ & \\
\hline Schwarz criterion & $-0,359$ & & $-0,348$ & & $-0,526$ & \\
\hline Estatística $F$ & 2,698 & 0,000 & 1,882 & 0,009 & 3,308 & 0,000 \\
\hline White Heteroskedasticity & & & & & & \\
\hline Test & 839,758 & 0,000 & 370,140 & 0,000 & 324,377 & 0,001 \\
\hline KB Test & 16,324 & 0,000 & 4,268 & 0,366 & 9,058 & 0,001 \\
\hline Durbin-Watson & 1,891 & & 1,942 & & 2,017 & \\
\hline Breusch-Godfrey Serial & & & & & & \\
\hline Correlation LM Test & 4,926 & 0,085 & 5,156 & 0,076 & 15,687 & 0,000 \\
\hline Jarque-Bera Test & 1131843 & 0,000 & 1262125 & 0,000 & 1085207 & 0,000 \\
\hline Observações & 1687 & & 1687 & & 1359 & \\
\hline
\end{tabular}

Na Tabela 30, observe-se que o grau de ajustamento do modelo Pae, aplicado no contexto chileno, é baixo $\left(R^{2}=0,068\right)$ e apresenta resíduos heteroscedásticos e não autocorrelacionados. Semelhante aos demais modelos derivados do modelo Jones, a única variável explicativa relevante é $P P E_{i t}$ e que os coeficientes das outras variáveis não são significativamente diferentes de zero. Para o modelo Pae no contexto chileno, as dummies para os setores de agropecuária e pesca $(\beta=0,030)$, papel e celulose $(\beta=0,042))$, petróleo e gás 
$(\beta=0,033)$ e têxtil $(\beta=0,090)$ foram, estatisticamente, significativas para estimação do comportamento dos accruals.

O modelo proposto (com as proxies de gerenciamento das atividades operacionais) para a amostra chilena tem problemas de correlação serial e heteroscedasticidade. Existe um aumento significativo no grau de ajustamento, sendo que o $R^{2}$ é igual 0,203, mas somente as variáveis $A I_{i t}, D \Delta E_{i t-1}$ e $T A_{i t-1}$ são significativas para explicar o comportamento dos accruals totais. Observe-se, também, que, essas variáveis possuem sinal esperado conforme descrito na seção 3.6.2.

Tabela 30 - Estimação dos modelos operacionais no contexto chileno - Parte C

\begin{tabular}{|c|c|c|c|c|c|c|}
\hline & \multicolumn{2}{|c|}{ Pae } & \multicolumn{2}{|c|}{ Proposto } & \multicolumn{2}{|c|}{$\begin{array}{l}\text { Proposto } \\
\text { (sem RM) }\end{array}$} \\
\hline & coeficiente & p-value & coeficiente & p-value & coeficiente & p-value \\
\hline Constante & & & 0,052 & 0,258 & 0,038 & 0,356 \\
\hline $1 / \mathrm{A}_{\mathrm{it}-1}$ & $-8591,414$ & 0,035 & & & & \\
\hline$\Delta \mathrm{R}_{\mathrm{it}}$ & 0,026 & 0,475 & & & & \\
\hline $\mathrm{PPE}_{\text {it }}$ & $-0,105$ & 0,000 & & & & \\
\hline $\mathrm{FCO}_{\text {it }}$ & $-0,138$ & 0,116 & $-0,030$ & 0,947 & $-0,584$ & 0,000 \\
\hline $\mathrm{FCO}_{\text {it-1 }}$ & $-0,020$ & 0,589 & & & & \\
\hline $\mathrm{TA}_{\mathrm{it}-1}$ & $-0,059$ & 0,097 & $-0,079$ & 0,014 & $-0,074$ & 0,008 \\
\hline $\mathrm{R}_{\mathrm{it}}$ & & & 0,119 & 0,638 & 0,247 & 0,109 \\
\hline $\mathrm{CD}_{\text {it }}$ & & & $-0,154$ & 0,539 & $-0,249$ & 0,106 \\
\hline $\mathrm{AI}_{\mathrm{it}}$ & & & $-0,110$ & 0,000 & $-0,109$ & 0,000 \\
\hline $\mathrm{AD}_{\text {it }}$ & & & 0,124 & 0,766 & 0,028 & 0,947 \\
\hline $\mathrm{E}_{\mathrm{it}}$ & & & 0,439 & 0,186 & 0,298 & 0,153 \\
\hline$E_{i t}^{2}$ & & & 0,071 & 0,382 & 0,069 & 0,344 \\
\hline$\Delta \mathrm{E}_{\mathrm{t}-1}$ & & & 0,176 & 0,239 & 0,075 & 0,504 \\
\hline $\mathrm{D} \Delta \mathrm{E}_{\mathrm{it}-1}$ & & & $-0,022$ & 0,016 & $-0,017$ & 0,084 \\
\hline$\Delta \mathrm{E}_{\mathrm{it}-1}^{*} \mathrm{D} \Delta \mathrm{E}_{\mathrm{it}-1}$ & & & 0,073 & 0,799 & 0,322 & 0,042 \\
\hline Ab_Prod ${ }_{i t}$ & & & $-0,019$ & 0,679 & & \\
\hline $\mathrm{Ab} \_\mathrm{DO}_{\text {it }}$ & & & $-0,001$ & 0,967 & & \\
\hline $\mathrm{Ab} \_\mathrm{CFO}_{\text {it }}$ & & & $-0,605$ & 0,173 & & \\
\hline$R^{2}$ & 0,068 & & 0,203 & & 0,176 & \\
\hline$R^{2}$ ajustado & 0,047 & & 0,181 & & 0,156 & \\
\hline Akaike criterion & $-0,606$ & & $-0,799$ & & $-0,783$ & \\
\hline Schwarz criterion & $-0,489$ & & $-0,653$ & & $-0,654$ & \\
\hline Estatística $F$ & & & 9,107 & 0,000 & 8,858 & 0,000 \\
\hline White Heteroskedasticity & & & & & & \\
\hline Test & 630,979 & 0,000 & 197,838 & 0,000 & 929,285 & 0,000 \\
\hline KB Test & 11,576 & 0,000 & 2,394 & 0,000 & 3,245 & 0,000 \\
\hline Durbin-Watson & 2,104 & & 2,008 & & 2,066 & \\
\hline Breusch-Godfrey Serial & & & & & & \\
\hline Correlation LM Test & 4,648 & 0,098 & 10,954 & 0,004 & 3,177 & 0,204 \\
\hline Jarque-Bera Test & 846290 & 0,000 & 1387719 & 0,000 & 1303613 & 0,000 \\
\hline Observações & 1333 & & 1396 & & 1484 & \\
\hline
\end{tabular}

Nota-se que o modelo proposto sem as proxies para gerenciamento das atividades operacionais não apresenta autocorrelação nos resíduos, sendo que o $R^{2}$ é de 0,176 , e as variáveis $F C O_{i t}$ e $\Delta E_{i t-1} * D \Delta E_{i t-1}$ tornam-se significativas, enquanto o coeficiente da variável 
$D \Delta E_{i t-1}$ é não significativo. A causa de algumas variáveis não serem significativas para explicar o comportamento dos accruals totais se deve à correlação entre elas.

No modelo proposto sem RM, diversos coeficientes para os setores de atividade econômica foram significativos: agropecuária e pesca $(\beta=0,035)$, papel e celulose $(\beta=0,047))$, petróleo e gás $(\beta=0,026)$, têxtil $(\beta=0,072)$ e trasnsportes serviços $(0,028)$. Na especificação com as proxies de gerenciamento de resultados operacionais, somente a dummy para o setor têxtil foi significativa $(\beta=0,077)$.

As estimações dos parâmetros e dos testes estatísticos para as proxies de gerenciamento das atividades operacionais nas companhias chilenas estão descritos na Tabela 31. Os resultados evidenciam problemas de heteroscedasticidade e de autocorrelação (exceto $A b_{-} D O_{i t}$ ). Para as companhias chilenas, os modelos para captar o comportamento da produção e fluxo de caixa operacional tiveram um grau de ajustamento satisfatório, sugerindo que tais proxies têm bom poder preditivo na análise da manipulação das atividades operacionais.

Tabela 31 - Gerenciamento de atividades operacionais no contexto chileno

\begin{tabular}{|c|c|c|c|c|c|c|}
\hline & \multicolumn{2}{|c|}{ Produção } & \multicolumn{2}{|c|}{ Despesa Operacional } & \multicolumn{2}{|c|}{$\begin{array}{c}\text { Fluxo de Caixa } \\
\text { Operacional }\end{array}$} \\
\hline & coeficiente & p-value & coeficiente & p-value & coeficiente & p-value \\
\hline Constante & $-0,013$ & 0,285 & \multirow[t]{2}{*}{0,099} & \multirow[t]{2}{*}{0,000} & & \\
\hline $1 / \mathrm{A}_{\mathrm{it}-1}$ & $-20080,18$ & 0,039 & & & 5477,762 & 0,650 \\
\hline $\mathrm{R}_{\mathrm{it}}$ & 0,846 & 0,000 & \multirow[t]{3}{*}{0,100} & \multirow[t]{3}{*}{0,002} & 0,022 & 0,221 \\
\hline$\Delta \mathrm{R}_{\mathrm{it}}$ & $-0,548$ & 0,000 & & & 0,750 & 0,000 \\
\hline$\Delta \mathrm{R}_{\mathrm{it}-1}$ & $-0,015$ & 0,298 & & & & \\
\hline $\mathrm{R}_{\mathrm{it} *} \mathrm{D}_{\mathrm{it}}$ & & & 0,099 & 0,000 & & \\
\hline $\mathrm{R}_{\mathrm{it}-1}$ & & & $-0,101$ & 0,001 & & \\
\hline $\mathrm{R}_{\mathrm{it}-1} * \mathrm{D}_{\mathrm{it}-1}$ & & & 0,022 & 0,199 & & \\
\hline$R^{2}$ & 0,879 & & 0,164 & & 0,689 & \\
\hline$R^{2}$ ajustado & 0,878 & & 0,154 & & 0,685 & \\
\hline Akaike criterion & $-0,559$ & & 0,225 & & 0,228 & \\
\hline Schwarz criterion & $-0,493$ & & 0,294 & & 0,290 & \\
\hline Estatística $F$ & 617,622 & 0,000 & 15,575 & 0,000 & & \\
\hline White Heteroskedasticity & & & & & & \\
\hline Test & 1481,349 & 0,000 & 218,165 & 0,000 & 161,553 & 0,000 \\
\hline Durbin-Watson & 0,877 & & 2,066 & & 1,096 & \\
\hline Breusch-Godfrey Serial & & & & & & \\
\hline Correlation LM Test & 456,373 & 0,000 & 4,830 & 0,089 & 125,620 & 0,000 \\
\hline Jarque-Bera Test & 58158 & 0,000 & 19568,21 & 0,000 & 1983405 & 0,000 \\
\hline Observações & 1633 & & 1526 & & 1525 & \\
\hline
\end{tabular}

Com relação à comparação do nível de ajustamento dos modelos para a estimação dos accruals na amostra composta pelas companhias chilenas, verificou-se que o modelo proposto tem um grau de ajustamento menor do que no contexto brasileiro, tanto que muitas das variáveis empregadas não têm coeficientes significativamente diferentes de zero. 
Com base no $R^{2}$ ajustado, o modelo KS pelo método MQO apresentou maior poder preditivo do que o estimado por VI, mas pelos Critérios de Akaike e Schwarz (Tabela 32) e teste Vuong (Tabela 33), o modelo KS estimado pelo método IV é o de melhor especificação.

Tabela 32 - Comparação do ajuste dos modelos operacionais no contexto chileno

\begin{tabular}{l|r|r|r}
\hline \multicolumn{1}{c|}{ Modelos } & $\mathbf{R}^{2}$ ajustado & Akaike & Schwarz \\
\hline Setorial & 0,002 & $-0,439$ & $-0,403$ \\
Jones & 0,093 & $-0,520$ & $-0,433$ \\
KS & 0,016 & $-0,642$ & $-0,546$ \\
KS MQO & 0,026 & $-0,449$ & $-0,359$ \\
Marginal & 0,012 & $-0,435$ & $-0,348$ \\
Jones Forward Looking & 0,044 & $-0,634$ & $-0,526$ \\
Pae & 0,047 & $-0,606$ & $-0,489$ \\
Proposto & 0,181 & $-0,799$ & $-0,653$ \\
Proposto (sem manipulação real) & 0,156 & $-0,783$ & $-0,654$ \\
\hline
\end{tabular}

Tabela 33 - Comparação do ajuste dos modelos operacionais no contexto chileno - Teste Vuong

\begin{tabular}{|c|c|c|c|c|c|c|c|c|}
\hline Modelo & Setorial & Jones & KS & $\begin{array}{c}\text { KS } \\
\text { MQO }\end{array}$ & $\begin{array}{c}\text { Margi- } \\
\text { nal }\end{array}$ & JonesFI & Pae & $\begin{array}{c}\text { Propos- } \\
\text { to }\end{array}$ \\
\hline Jones & $\begin{array}{c}-2,958 \\
\text { Setorial }\end{array}$ & & & & & & & \\
\hline KS & $\begin{array}{l}4,322 \\
\mathrm{KS}\end{array}$ & $\begin{array}{l}9,802 \\
\mathrm{KS}\end{array}$ & & & & & & \\
\hline KS MQO & $\begin{array}{l}1,746 \\
\text { Indife- } \\
\text { rente }\end{array}$ & $\begin{array}{l}4,088 \\
\text { KS } \\
\text { MQO }\end{array}$ & $\begin{array}{l}-3,692 \\
\mathrm{KS}\end{array}$ & & & & & \\
\hline Marginal & $\begin{array}{c}1,123 \\
\text { Indife- } \\
\text { rente }\end{array}$ & $\begin{array}{r}3,229 \\
\text { Marginal }\end{array}$ & $\begin{array}{l}-3,957 \\
\mathrm{KS}\end{array}$ & $\begin{array}{c}-0,934 \\
\text { Indife- } \\
\text { rente }\end{array}$ & & & & \\
\hline JonesFl & $\begin{array}{c}5,021 \\
\text { JonesFl }\end{array}$ & $\begin{array}{r}10,375 \\
\text { JonesFl }\end{array}$ & $\begin{array}{r}4,357 \\
\text { JonesFl }\end{array}$ & $\begin{array}{r}5,530 \\
\text { JonesFl }\end{array}$ & $\begin{array}{r}4,712 \\
\text { JonesFl }\end{array}$ & & & \\
\hline Pae & $\begin{array}{l}3,122 \\
\mathrm{Pae}\end{array}$ & $\begin{array}{l}\text { 4,679 } \\
\mathrm{Pae}\end{array}$ & $\begin{array}{l}1,677 \\
\text { Indife- } \\
\text { rente }\end{array}$ & $\begin{array}{l}1,821 \\
\text { Indife- } \\
\text { rente }\end{array}$ & $\begin{array}{l}3,198 \\
\mathrm{Pae}\end{array}$ & $\begin{array}{r}-5,941 \\
\text { JonesFl }\end{array}$ & & \\
\hline Proposto & $\begin{array}{r}5,047 \\
\text { Proposto }\end{array}$ & $\begin{array}{r}7,410 \\
\text { Proposto }\end{array}$ & $\begin{array}{r}4,161 \\
\text { Proposto }\end{array}$ & $\begin{array}{r}4,668 \\
\text { Proposto }\end{array}$ & $\begin{array}{r}5,058 \\
\text { Proposto }\end{array}$ & $\begin{array}{r}2,313 \\
\text { Proposto }\end{array}$ & $\begin{array}{r}3,480 \\
\text { Proposto }\end{array}$ & \\
\hline $\begin{array}{l}\text { Proposto } \\
\text { sem RM }\end{array}$ & $\begin{array}{r}6,700 \\
\text { Proposto } \\
\text { sem RM }\end{array}$ & $\begin{array}{r}8,612 \\
\text { Proposto } \\
\text { sem RM }\end{array}$ & $\begin{array}{r}4,907 \\
\text { Proposto } \\
\text { sem RM }\end{array}$ & $\begin{array}{r}5,980 \\
\text { Proposto } \\
\text { sem RM }\end{array}$ & $\begin{array}{r}6,705 \\
\text { Proposto } \\
\text { sem RM }\end{array}$ & $\begin{array}{r}1,973 \\
\text { Proposto } \\
\text { sem RM }\end{array}$ & $\begin{array}{r}4,858 \\
\text { Proposto } \\
\text { sem RM }\end{array}$ & $\begin{array}{c}-0,773 \\
\text { Indife- } \\
\text { rente }\end{array}$ \\
\hline
\end{tabular}

Com base no critérios de Akaike, Schwarz e $R^{2}$ ajustado (Tabela 32), bem como pelo teste Vuong (Tabela 33), o modelo proposto neste trabalho tem o maior poder preditivo do comportamento dos accruals totais. O teste Vuong indica, ainda, que a escolha entre os modelos proposto com ou sem proxies de gerenciamento das atividades operacionais é indiferente, pois não apresentam desempenhos significativamente diferentes entre eles para estimar o comportamento dos accruals das companhias abertas chilenas. 
Retornando à questão da multicolineariedade entre as variáveis no modelo proposto no contexto chileno, observe-se que as variáveis $R_{i t}$ e $C D_{i t}$, têm forte correlação e a variável $F C O_{i t}$ tem correlação alta com as variáveis $E_{i t}$ e $A b_{-} C F O_{i t}$.

Os testes de variáveis redundantes mostram que as variáveis $R_{i t}, C D_{i t}$ e $F C O_{i t}$ não são relevantes para o modelo proposto no contexto chileno e que, no caso de sua exclusão, o grau de ajustamento não seria significativamente afetado.

Tabela 34 - Teste de multicolineariedade Variance Inflation Factor no contexto chileno

\begin{tabular}{|c|c|c|c|c|c|c|c|}
\hline & Jones & KS & Marginal & $\begin{array}{c}\text { Jones } \\
\text { FL }\end{array}$ & Pae & Proposto & $\begin{array}{c}\text { Proposto } \\
\text { (sem RM) }\end{array}$ \\
\hline 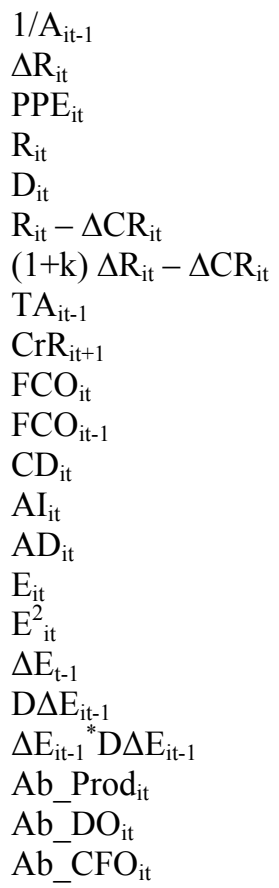 & $\begin{array}{l}1,028 \\
1,079 \\
1,107\end{array}$ & $\begin{array}{l}1,000 \\
1,121 \\
1,121\end{array}$ & $\begin{array}{l}241,643 \\
241,643\end{array}$ & $\begin{array}{l}1,021 \\
1,014 \\
1,006\end{array}$ & $\begin{array}{l}1,054 \\
1,082 \\
1,310\end{array}$ & $\begin{array}{r}1,067 \\
10,632 \\
164,700 \\
1,138 \\
1,014 \\
9,555 \\
2,666 \\
1,604 \\
1,340 \\
2,374 \\
2,278 \\
1,082 \\
6,167\end{array}$ & $\begin{array}{r}1,052 \\
3,696 \\
100,692 \\
1,127 \\
1,008 \\
5,749 \\
2,370 \\
1,703 \\
1,255 \\
1,920\end{array}$ \\
\hline
\end{tabular}

Igualmente, no contexto chileno, efetuou-se a análise fatorial exploratória com o intuito de identificar fatores e solucionar problemas de multicolineariedade. A Tabela 35 evidencia que o teste KMO tem um grau de explicação de 0,559 , considerado ruim aplicação dessa técnica estatística. (TABACHNICK; FIDELL, 2001, p.589; HAIR JR et al, 2005, p.98; PESTANA; GAGEIRO, 2005, p.491).

Tabela 35 - KMO and Bartlett's Test - Chile

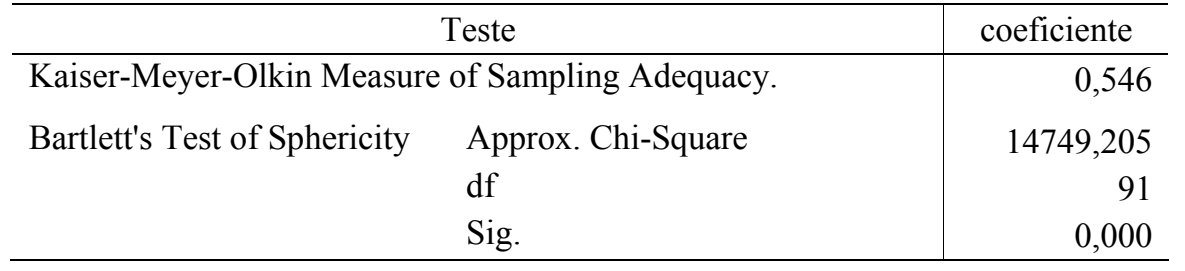


Observando a Correlação da Matriz Anti-Imagem (Apêndice 72), verificou-se que algumas variáveis possuem MSA inferior a 0,500. Foi realizada uma nova tentativa sem as variáveis com MSA menor que 0,500 .

Na segunda tentativa, o KMO passou a ser de 0,649, sendo que a Correlação da Matriz AntiImagem (Apêndice 73) apresentou mais variáveis com MSA inferior a 0,500, o que limita novas tentativas. Com base no Apêndice 74, as variáveis foram agrupadas, porém não se observou a formação de nenhum fator relevante.

Analisando os testes de variáveis redundantes (Tabela 36), é constatado que as proxies de comportamento anormal dos custos de produção e das despesas operacionais são variáveis irrelevantes no modelo proposto para as empresas chilenas, podendo ser extraídas no processo de estimação.

Tabela 36 - Testes de variáveis redundantes para as proxies de gerenciamento de atividades operacionais - Chile

\begin{tabular}{|c|c|c|}
\hline & \multicolumn{2}{|c|}{ log likelihood ratio } \\
\hline & coeficiente & p-value \\
\hline Ab_Prod ${ }_{i t}$ & 0,155 & 0,694 \\
\hline $\mathrm{Ab}_{-} \mathrm{DO}_{\mathrm{it}}$ & 0,003 & 0,955 \\
\hline $\mathrm{Ab}_{-} \mathrm{CFO}_{\mathrm{it}}$ & 4,648 & 0,031 \\
\hline $\mathrm{Ab}_{-}$Prod $_{\text {it }}$ Ab_DO $\mathrm{DO}_{\text {it }}$ & 0,157 & 0,925 \\
\hline $\mathrm{Ab}^{-} \operatorname{Prod}_{\text {it }} \mathrm{Ab}_{-} \mathrm{CFO}_{\text {it }}$ & 4,947 & 0,084 \\
\hline $\mathrm{Ab}_{-} \mathrm{DO}_{\text {it }} \mathrm{Ab} \mathrm{Ab}_{-} \mathrm{C} F \mathrm{O}_{\mathrm{it}}$ & 4,959 & 0,084 \\
\hline 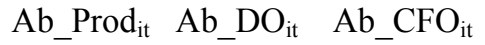 & 5,236 & 0,155 \\
\hline
\end{tabular}

Retirando essas variáveis, o modelo proposto teria os mesmos valores para o $R^{2}$ e $R^{2}$ ajustado do modelo originalmente proposto e um pequeno declínio nas estatísticas do critério de Akaike $(-0,802)$ e Schwarz $(-0,663)$. Apesar dos testes apresentados na Tabela 35 indicarem que a variável $\mathrm{Ab}_{-} \mathrm{CFO}_{\text {it }}$ não é uma variável redundante, se ela também fosse extraída, o $R^{2} \mathrm{e}$ $R^{2}$ ajustado seriam pouco afetados $(0,200$ e 0,180 , respectivamente) e com inexpressiva alteração nos indicadores de Akaike $(-0,800)$ e Schwarz $(-0,665)$.

Tabela 37 - Testes de variáveis redundantes para as proxies de conservadorismo - Chile

\begin{tabular}{|c|c|c|}
\hline & \multicolumn{2}{|c|}{ log likelihood ratio } \\
\hline & coeficiente & p-value \\
\hline$\Delta \mathrm{E}_{\mathrm{t}-1}$ & 18,477 & 0,000 \\
\hline $\mathrm{D} \Delta \mathrm{E}_{\mathrm{it}-1}$ & 4,713 & 0,030 \\
\hline$\Delta \mathrm{E}_{\mathrm{it}-1}^{*} \mathrm{D} \Delta \mathrm{E}_{\mathrm{it}-1}$ & 0,445 & 0,505 \\
\hline$\Delta \mathrm{E}_{\mathrm{t}-1} \quad \mathrm{D} \Delta \mathrm{E}_{\mathrm{it}-1}$ & 27,636 & 0,000 \\
\hline$\Delta \mathrm{E}_{\mathrm{it}-1}^{*} \mathrm{D} \Delta \mathrm{E}_{\mathrm{it}-1}$ & 23,876 & 0,000 \\
\hline $\mathrm{D} \Delta \mathrm{E}_{\mathrm{it}-1} \quad \Delta \mathrm{E}_{\mathrm{it}-1}{ }^{*} \mathrm{D} \Delta \mathrm{E}_{\mathrm{it}-1}$ & 6,439 & 0,040 \\
\hline$\Delta \mathrm{E}_{\mathrm{t}-1} \quad \mathrm{D} \Delta \mathrm{E}_{\mathrm{it}-1} \quad \Delta \mathrm{E}_{\mathrm{it}-1}{ }^{*} \mathrm{D} \Delta \mathrm{E}_{\mathrm{it}-1}$ & 41,365 & 0,000 \\
\hline
\end{tabular}


Por outro lado, o conjunto de variáveis que forma a proxy do conservadorismo contábil, apresenta-se relevante para o modelo, conforme pode ser observado na Tabela 37 na qual se evidencia que essas variáveis são relevantes (excetuando-se a análise isolada da variável de interação). Uma exclusão da proxy do conservadorismo no modelo proposto faz com que o $R^{2}$ caia para 0,179 e o $R^{2}$ ajustado para 0,158 , enquanto o critério de informação de Akaike teria o valor de $-0,774$ e o de Schwarz o valor de -0,638.

A análise dos modelos operacionais, no contexto chileno, sugere que as variáveis utilizadas para controlar o gerenciamento das atividades operacionais não são relevantes para explicar e prever os accruals discricionários e não-discricionários, ao contrário do que ocorre com a proxy para controlar o nível de conservadorismo.

\subsubsection{México}

Observa-se, pelos dados apresentados nas Tabelas 38 a 40, que todos os modelos operacionais rejeitam a hipótese nula de normalidade para as amostras com as companhias abertas mexicanas. Também foi verificado que todos os modelos, nesse ambiente econômico, atendem ao pressuposto da exogeneidade, pois não existe forte correlação entre os resíduos e as variáveis explicativas (Apêndices 1 e 2).

Tabela 38 - Estimação dos modelos operacionais no contexto mexicano - Parte A

\begin{tabular}{|c|c|c|c|c|c|c|}
\hline & \multicolumn{2}{|c|}{ Setorial } & \multicolumn{2}{|c|}{ Jones } & \multicolumn{2}{|c|}{$\mathbf{K S}$} \\
\hline & coeficiente & p-value & coeficiente & p-value & coeficiente & p-value \\
\hline Constante & 0,022 & 0,008 & & & $-0,031$ & 0,001 \\
\hline Mediana TA & 1,447 & 0,000 & & & & \\
\hline $1 / \mathrm{A}_{\mathrm{it}-1}$ & & & $-7,242$ & 0,027 & & \\
\hline$\Delta \mathrm{R}_{\mathrm{it}}$ & & & 0,079 & 0,030 & & \\
\hline $\mathrm{PPE}_{\text {it }}$ & & & $-0,066$ & 0,003 & $-0,456$ & 0,000 \\
\hline $\mathrm{R}_{\mathrm{it}}$ & & & & & $-0,040$ & 0,101 \\
\hline $\mathrm{D}_{\text {it }}$ & & & & & 0,194 & 0,000 \\
\hline$R^{2}$ & 0,059 & & 0,135 & & 0,169 & \\
\hline$R^{2}$ ajustado & 0,058 & & 0,123 & & 0,156 & \\
\hline Akaike criterion & $-0,865$ & & $-0,923$ & & $-0,961$ & \\
\hline Schwarz criterion & $-0,857$ & & $-0,849$ & & $-0,881$ & \\
\hline Estatística $F$ & 78,144 & 0,000 & & & 13,454 & 0,000 \\
\hline White Heteroskedasticity & & & & & & \\
\hline Test & 6,842 & 0,033 & 381,758 & 0,000 & 230,660 & 0,000 \\
\hline KB Test & 1,152 & 0,371 & 0,468 & 0,001 & 0,563 & 0,216 \\
\hline Durbin-Watson & 1,778 & & 1,804 & & 1,880 & \\
\hline Breusch-Godfrey Serial & & & & & & \\
\hline Correlation LM Test & 1,938 & 0,380 & 0,000 & 1,000 & 1,917 & 0,383 \\
\hline Jarque-Bera Test & 72648,250 & 0,000 & 68535,970 & 0,000 & 76561,380 & 0,000 \\
\hline Observações & 1243 & & 1243 & & 1212 & \\
\hline
\end{tabular}


$\mathrm{Na}$ Tabela 38, observe-se que os modelos apresentados rejeitam a hipótese nula de homoscedasticidade pelo teste de White, mas não apresentam correlação serial. Os modelos Setorial, Jones e KS apresentam um melhor poder de explicação do que nos ambientes econômicos anteriormente analisados, sendo que as estatísticas $F$ correspondentes (quando calculado) confirmam que o conjunto das variáveis independentes explica o comportamento dos accruals totais.

Com relação aos testes $t$ para os coeficientes dos parâmetros, somente a variável $R_{i t}$ no modelo KS não se apresenta significativamente diferente de 'zero'. Realizando o teste $\log$ likelihood ratio para variáveis redundantes, obteve-se o valor de 1,002 ( $p$-value $=0,317)$, o que sugere que essa variável não é relevante no modelo $\mathrm{KS}$ e, se ela fosse extraída, o $R^{2}$ ajustado permaneceria idêntico. No mesmo modelo, o coeficiente da variável $D_{i t}$ tem sinal diferente do esperado para o modelo.

No modelo Jones, os setores com coeficientes significativos foram os de construção $(0,062)$ e de telecomunicações $(-0,095)$, enquanto no KS foram comércio $(-0,054)$, máquinas industriais $(-0,048)$ e veículos e preças $(-0,098)$.

Observando-se a Tabela 39, o modelo KS estimado pelo MQO teria pouca alteração no $R^{2}$ $(0,171)$ em relação ao estimação por IV e continuaria apresentando heteroscedasticidade, mas o coeficiente da variável $R_{i t}$ passa a ser diferente de zero e, portanto, significativo para o modelo. No modelo KS MQO, a variável $D_{i t}$ tem sinal esperado e os setores de construção $(0,052)$, minerais não metálicos $(-0,044)$ e telecomunicações $(0,125)$ têm coeficientes significativos.

No modelo Marginal, $R^{2}$ é de 0,086 e a variável de receita líquida não tem coeficiente significativo para o modelo no contexto mexicano, sendo que esse modelo também apresenta resíduos heteroscedásticos. Já o modelo Jones Forward Looking apresenta $R^{2}$ igual a 0,192 e resíduos heteroscedásticos (pelo teste White) e autocorrelacionados e os coeficientes das variáveis $T A_{i t-1}$ e $C r R_{i t+1}$ são estatisticamente iguais a zero. Realizando o teste para variáveis redundantes, obteve-se $p$-value próximo de 0,625 para ambas as variáveis, o que sugere que elas sejam extraídas do modelo Jones Forward Looking, nesse caso o $R^{2}$ ajustado seria de 0,177 .

Os setores com $\beta^{\prime}$ s significativos no modelo Marginal foram: construção $(0,078)$, telecomunicações $(-0,140)$, transportes serviços $(-0,069)$ e veículos e peças $(-0,082)$, enquanto telecomunicações $(-0,122)$, transportes e serviços $(-0,066)$ e veículos e peças $(-0,058)$, foram significativos no modelo Jones FL. 
Tabela 39 - Estimação dos modelos operacionais no contexto mexicano - Parte B

\begin{tabular}{|c|c|c|c|c|c|c|}
\hline & \multicolumn{2}{|c|}{ KS MQO } & \multicolumn{2}{|c|}{ Marginal } & \multicolumn{2}{|c|}{ Jones FL } \\
\hline & coeficiente & p-value & coeficiente & p-value & coeficiente & p-value \\
\hline Constante & $-0,017$ & 0,322 & $-0,032$ & 0,002 & 0,039 & 0,000 \\
\hline $\mathrm{R}_{\mathrm{it}}$ & 0,376 & 0,000 & 0,211 & 0,281 & & \\
\hline $\mathrm{D}_{\text {it }}$ & $-0,362$ & 0,001 & & & & \\
\hline $\mathrm{PPE}_{\mathrm{it}}$ & $-0,047$ & 0,003 & & & $-0,090$ & 0,000 \\
\hline $\mathrm{R}_{\mathrm{it}}-\Delta \mathrm{CR}_{\mathrm{it}}$ & & & $-0,190$ & 0,030 & & \\
\hline$(1+\mathrm{k}) \Delta \mathrm{R}_{\mathrm{it}}-\Delta \mathrm{CR}_{\mathrm{it}}$ & & & & & 0,089 & 0,037 \\
\hline $\mathrm{TA}_{\mathrm{it}-1}$ & & & & & $-0,027$ & 0,709 \\
\hline $\mathrm{CrR}_{\mathrm{it}+1}$ & & & & & $-1,37 \mathrm{E}-05$ & 0,840 \\
\hline$R^{2}$ & 0,171 & & 0,086 & & 0,192 & \\
\hline$R^{2}$ ajustado & 0,159 & & 0,074 & & 0,176 & \\
\hline Akaike criterion & $-0,964$ & & $-0,868$ & & $-1,188$ & \\
\hline Schwarz criterion & $-0,886$ & & $-0,794$ & & $-1,092$ & \\
\hline Estatística $F$ & 14,067 & 0,000 & 6,797 & 0,000 & 12,546 & 0,000 \\
\hline White Heteroskedasticity & & & & & & \\
\hline Test & 440,124 & 0,000 & 353,450 & 0,000 & 534,378 & 0,000 \\
\hline KB Test & 0,087 & 0,331 & 1,650 & 0,003 & 0,039 & 0,292 \\
\hline Durbin-Watson & 1,862 & & 1,795 & & 1,990 & \\
\hline Breusch-Godfrey Serial & & & & & & \\
\hline Correlation LM Test & 0,275 & 0,872 & 1,046 & 0,592 & 6,818 & 0,000 \\
\hline Jarque-Bera Test & 96661,080 & 0,000 & 66868,130 & 0,000 & 37880,850 & 0,000 \\
\hline Observações & 1243 & & 1243 & & 1025 & \\
\hline
\end{tabular}

Conforme a Tabela 40, as estimativas do modelo Pae (2005) atendem ao pressuposto da ausência de autocorrelação, mas também apresenta problema de heteroscedasticidade e os coeficientes das variáveis $F C O_{i t}$ e $T A_{i t-1}$ não são significativamente diferentes de zero. $\mathrm{O}$ seu grau de ajustamento $\left(R^{2}\right)$ é estimado em 0,164 . Porém, pelo teste de variáveis redundantes, a variável $F C O_{i t}$ é uma variável relevante para o modelo, enquanto esse mesmo teste confirma que a variável $T A_{i t-1}$ é irrelevante, sendo que, no caso de sua exclusão, o $R^{2}$ ajustado permanece idêntico ao modelo original. Nesse modelo, siderurgia e metalurgia $(0,043)$ e telecomunicações $(-0,095)$ foram significantes.

O modelo proposto com ou sem as variáveis de controle para gerenciamento das atividades reais apresenta problemas de heteroscedasticidade pelo teste White, mas não existe presença de correlação serial em ambos os casos. Por essas duas especificações do modelo, o grau de ajustamento da curva é o melhor entre todos os modelos analisados, evidenciando o $R^{2}$ superior a 0,400 
Tabela 40 - Estimação dos modelos operacionais no contexto mexicano - Parte C

\begin{tabular}{|c|c|c|c|c|c|c|}
\hline \multirow{2}{*}{ thes } & \multicolumn{2}{|l|}{ Pae } & \multicolumn{2}{|c|}{ Proposto } & \multicolumn{2}{|c|}{ Proposto (sem RM) } \\
\hline & coeficiente & $p$-value & coeficiente & p-value & coeficiente & p-value \\
\hline Constante & & & $-0,030$ & 0,093 & $-0,033$ & 0,044 \\
\hline $1 / \mathrm{A}_{\mathrm{it}-1}$ & $-6,685$ & 0,174 & & & & \\
\hline$\Delta \mathrm{R}_{\mathrm{it}}$ & 0,077 & 0,039 & & & & \\
\hline $\mathrm{PPE}_{\text {it }}$ & $-0,065$ & 0,011 & & & & \\
\hline $\mathrm{FCO}_{\text {it }}$ & $-0,159$ & 0,064 & 0,083 & 0,828 & $-0,566$ & 0,000 \\
\hline $\mathrm{FCO}_{\mathrm{it}-1}$ & 0,145 & 0,012 & & & & \\
\hline $\mathrm{TA}_{\mathrm{it}-1}$ & 0,051 & 0,377 & $-0,032$ & 0,552 & $-0,022$ & 0,700 \\
\hline $\mathrm{R}_{\mathrm{it}}$ & & & 0,529 & 0,000 & 0,543 & 0,000 \\
\hline $\mathrm{CD}_{\text {it }}$ & & & $-0,543$ & 0,000 & $-0,514$ & 0,000 \\
\hline $\mathrm{AI}_{\mathrm{it}}$ & & & 0,028 & 0,132 & 0,030 & 0,091 \\
\hline $\mathrm{AD}_{\mathrm{it}}$ & & & $-0,035$ & 0,312 & $-0,033$ & 0,356 \\
\hline$E_{\text {it }}$ & & & 0,333 & 0,000 & 0,331 & 0,000 \\
\hline$E^{2}{ }_{i t}$ & & & $-0,102$ & 0,001 & $-0,093$ & 0,001 \\
\hline$\Delta \mathrm{E}_{\mathrm{t}-1}$ & & & 0,035 & 0,748 & 0,019 & 0,850 \\
\hline $\mathrm{D} \Delta \mathrm{E}_{\mathrm{it}-1}$ & & & 0,004 & 0,691 & 0,000 & 0,962 \\
\hline$\Delta \mathrm{E}_{\mathrm{it}-1}{ }^{*} \mathrm{D} \Delta \mathrm{E}_{\mathrm{it}-1}$ & & & $-0,044$ & 0,715 & $-0,038$ & 0,744 \\
\hline Ab_Prod ${ }_{i t}$ & & & 0,039 & 0,116 & & \\
\hline $\mathrm{Ab}_{-}^{-} \mathrm{DO}_{\mathrm{it}}$ & & & 0,032 & 0,287 & & \\
\hline $\mathrm{Ab}_{-} \mathrm{CFO}_{\text {it }}$ & & & $-0,677$ & 0,083 & & \\
\hline$R^{2}$ & 0,164 & & 0,448 & & 0,416 & \\
\hline$R^{2}$ ajustado & 0,150 & & 0,433 & & 0,403 & \\
\hline Akaike criterion & $-1,047$ & & $-1,400$ & & $-1,395$ & \\
\hline Schwarz criterion & $-0,959$ & & $-1,261$ & & $-1,282$ & \\
\hline Estatística $F$ & & & 29,410 & 0,000 & 32,408 & 0,000 \\
\hline White Heteroskedasticity & & & & & & \\
\hline Test & 717,129 & 0,000 & 972,151 & 0,000 & 1015,046 & 0,000 \\
\hline KB Test & 0,591 & 0,000 & 0,072 & 0,222 & 0,052 & 0,232 \\
\hline Durbin-Watson & 1,942 & & 2,025 & & 1,994 & \\
\hline Breusch-Godfrey Serial & & & & & & \\
\hline Correlation LM Test & 0,500 & 0,779 & 5,063 & 0,080 & 5,673 & 0,059 \\
\hline Jarque-Bera Test & 50448,140 & 0,000 & 29758,380 & 0,000 & 32582,660 & 0000 \\
\hline Observações & 1212 & & 1082 & & 1212 & \\
\hline
\end{tabular}

Porém somente as variáveis $R_{i t}, C D_{i t}, E_{i t}$, e $E_{i t}^{2}$ são significativamente diferentes de zero nos dois modelos, considerando-se um nível de significância de 5\%. Porém, a variável $F C O_{i t}$ no modelo proposto com gerenciamento de atividades operacionais tem coeficiente igual a zero pelo teste $t$, enquanto pelo modelo proposto alternativo é estatisticamente diferente de zero. Isso se deve pelo fato de essa variável ser correlacionada significativamente com a proxy do fluxo de caixa anormal $\left(A b_{-} C F O_{i t}\right)$.

Analisando-se o sentido dos sinais esperados das estimativas, verificou-se que os coeficientes significativos do modelo proposto no contexto das companhias abertas mexicanas, tiveram os sinais preditos na seção 3.6.2.

No modelo proposto para o ambiente mexicano, os setores com coeficientes significantes foram alimentos $(-0,108)$, minerais não metálicos $(-0,135)$, telecomunicaçõe $(-0,200)$ e veículos e peças $(0,060)$. 
A Tabela 41 demonstra as estatísticas dos parâmetros e dos testes estatísticos para as proxies de gerenciamento dos resultados contábeis através das atividades operacionais. Observe-se que todas as regressões têm presença de heteroscedasticidade e autocorrelação e a proxy do comportamento do custo de produção $\left(R^{2}=0,907\right)$ tem um alto grau de ajustamento.

Tabela 41 - Gerenciamento de atividades operacionais no contexto mexicano

\begin{tabular}{|c|c|c|c|c|c|c|}
\hline & \multicolumn{2}{|c|}{ Produção } & \multicolumn{2}{|c|}{ Despesa Operacional } & \multicolumn{2}{|c|}{$\begin{array}{c}\text { Fluxo de Caixa } \\
\text { Operacional }\end{array}$} \\
\hline & coeficiente & p-value & coeficiente & p-value & coeficiente & p-value \\
\hline Constante & $-0,132$ & 0,000 & \multirow[t]{2}{*}{0,154} & \multirow[t]{2}{*}{0,000} & & \\
\hline $1 / \mathrm{A}_{\mathrm{it}-1}$ & 46,191 & 0,000 & & & $-16,746$ & 0,000 \\
\hline $\mathrm{R}_{\mathrm{it}}$ & 0,812 & 0,000 & \multirow[t]{3}{*}{0,183} & \multirow[t]{3}{*}{0,012} & 0,053 & 0,000 \\
\hline$\Delta \mathrm{R}_{\mathrm{it}}$ & $-0,099$ & 0,004 & & & \multirow[t]{5}{*}{0,068} & \multirow[t]{5}{*}{0,092} \\
\hline$\Delta \mathrm{R}_{\mathrm{it}-1}$ & \multirow[t]{4}{*}{$-0,008$} & \multirow[t]{4}{*}{0,703} & & & & \\
\hline $\mathrm{R}_{\mathrm{it}^{*}} \mathrm{D}_{\mathrm{it}}$ & & & 0,040 & 0,459 & & \\
\hline $\mathrm{R}_{\mathrm{it}-1}$ & & & $-0,132$ & 0,037 & & \\
\hline $\mathrm{R}_{\mathrm{it}-1} * \mathrm{D}_{\mathrm{it}-1}$ & & & 0,097 & 0,012 & & \\
\hline$R^{2}$ & 0,908 & \multirow{7}{*}{0,000} & 0,332 & \multirow{7}{*}{0,000} & 0,172 & \\
\hline$R^{2}$ ajustado & 0,906 & & 0,320 & & 0,161 & \\
\hline Akaike criterion & $-0,581$ & & 0,314 & & $-1,071$ & \\
\hline Schwarz criterion & $-0,497$ & & 0,405 & & \multirow[t]{2}{*}{$-0,997$} & \\
\hline Estatística $F$ & 624,996 & & 28,076 & & & \\
\hline Durbin-Watson & 0,392 & & 1,765 & & \multirow{2}{*}{\multicolumn{2}{|c|}{1,569}} \\
\hline White Heteroskedasticity & & & & & & \\
\hline Test & 758,722 & \multirow[t]{2}{*}{0,000} & 662,763 & \multirow[t]{2}{*}{0,000} & \multirow[t]{2}{*}{786,729} & \multirow[t]{2}{*}{0,000} \\
\hline Breusch-Godfrey Serial & & & & & & \\
\hline Correlation LM Test & 758,375 & 0,000 & 9,427 & 0,009 & 72,377 & 0,000 \\
\hline Jarque-Bera Test & 3656,995 & 0,000 & 9699,807 & 0,000 & 33327,690 & 0,000 \\
\hline Observações & 1224 & & 1094 & & 1254 & \\
\hline
\end{tabular}

Conforme a Tabela 42, observe-se, também, que, no contexto das companhias abertas mexicanas, todos os modelos operacionais para a detecção de accruals discricionários apresentaram melhores graus de ajustamento do que nos ambientes econômicos anteriormente analisados (exceto o modelo marginal e Pae no contexto brasileiro pela análise do $R^{2}$ ). Assim como observado no contexto brasileiro e chileno, o modelo proposto tem maior poder preditivo do que os demais modelos concorrentes e, portanto, também descreve melhor o comportamento dos accruals totais no ambiente econômico mexicano.

Tabela 42 - Comparação do ajuste dos modelos operacionais no contexto mexicano

\begin{tabular}{l|r|r|r}
\hline \multicolumn{1}{c|}{ Modelos } & $\mathbf{R}^{2}$ ajustado & Akaike & \multicolumn{1}{c}{ Schwarz } \\
\hline Setorial & 0,058 & $-0,865$ & $-0,857$ \\
Jones & 0,123 & $-0,923$ & $-0,849$ \\
KS & 0,156 & $-0,961$ & $-0,881$ \\
KS MQO & 0,159 & $-0,964$ & $-0,886$ \\
Marginal & 0,074 & $-0,868$ & $-0,794$ \\
Jones Forward Looking & 0,176 & $-1,188$ & $-1,092$ \\
Pae & 0,150 & $-1,047$ & $-0,959$ \\
Proposto & 0,433 & $-1,400$ & $-1,261$ \\
Proposto (sem manipulação real) & 0,403 & $-1,395$ & $-1,282$ \\
\hline
\end{tabular}


Com base nos critérios de avaliação apresentados na Tabela 42, o modelos KS apresenta praticamente o mesmo poder preditivo quando estimado pelo método IV e método MQO, sendo que o teste Vuong (Tabela 43) considera indiferente a escolha entre esses dois métodos de estimação.

Tabela 43 - Comparação do ajuste dos modelos operacionais no contexto mexicano - Teste Vuong

\begin{tabular}{|c|c|c|c|c|c|c|c|c|}
\hline Modelo & Setorial & Jones & KS & $\begin{array}{c}\text { KS } \\
\text { MQO }\end{array}$ & $\begin{array}{c}\text { Margi- } \\
\text { nal }\end{array}$ & JonesFL & Pae & $\begin{array}{c}\text { Propos- } \\
\text { to } \\
\end{array}$ \\
\hline Jones & $\begin{array}{c}-6,531 \\
\text { Setorial }\end{array}$ & & & & & & & \\
\hline $\mathrm{KS}$ & $\begin{array}{c}1,296 \\
\text { Indife- } \\
\text { rente }\end{array}$ & $\begin{array}{l}9,190 \\
\text { KS } \\
\end{array}$ & & & & & & \\
\hline KS MQO & $\begin{array}{l}1,028 \\
\text { Indife- } \\
\text { rente }\end{array}$ & $\begin{array}{c}8,956 \\
\text { KS } \\
\text { MQO }\end{array}$ & $\begin{array}{l}-0,372 \\
\text { Indife- } \\
\text { rente }\end{array}$ & & & & & \\
\hline Marginal & $\begin{array}{l}-0,797 \\
\text { Indife- } \\
\text { rente }\end{array}$ & $\begin{array}{r}6,458 \\
\text { Marginal }\end{array}$ & $\begin{array}{c}-1,819 \\
\text { Indife- } \\
\text { rente }\end{array}$ & $\begin{array}{l}-1,767 \\
\text { Indife- } \\
\text { rente }\end{array}$ & & & & \\
\hline JonesFl & $\begin{array}{c}2,589 \\
\text { JonesFL }\end{array}$ & $\begin{array}{c}3,997 \\
\text { JonesFL }\end{array}$ & $\begin{array}{r}2,661 \\
\text { JonesFL }\end{array}$ & $\begin{array}{r}2,867 \\
\text { JonesFL }\end{array}$ & $\begin{array}{c}2,915 \\
\text { JonesFL }\end{array}$ & & & \\
\hline $\mathrm{Pae}$ & $\begin{array}{r}-5,079 \\
\text { Setorial } \\
\end{array}$ & $\begin{array}{r}0,326 \\
\text { Indiferen } \\
\text { te } \\
\end{array}$ & $\begin{array}{l}-7,043 \\
\mathrm{KS} \\
\end{array}$ & $\begin{array}{c}-5,794 \\
\text { KS } \\
\text { MQO }\end{array}$ & $\begin{array}{r}-4,405 \\
\text { Marginal } \\
\end{array}$ & $\begin{array}{l}-10,023 \\
\text { JonesFL }\end{array}$ & & \\
\hline Proposto & $\begin{array}{r}2,421 \\
\text { Proposto } \\
\end{array}$ & $\begin{array}{r}4,964 \\
\text { Proposto }\end{array}$ & $\begin{array}{r}3,279 \\
\text { Proposto } \\
\end{array}$ & $\begin{array}{r}3,422 \\
\text { Proposto }\end{array}$ & $\begin{array}{r}3,833 \\
\text { Proposto }\end{array}$ & $\begin{array}{r}2,086 \\
\text { Proposto }\end{array}$ & $\begin{array}{r}4,659 \\
\text { Proposto } \\
\end{array}$ & \\
\hline $\begin{array}{l}\text { Proposto } \\
\text { sem RM }\end{array}$ & $\begin{array}{r}2,670 \\
\text { Proposto } \\
\text { sem RM } \\
\end{array}$ & $\begin{array}{r}5,529 \\
\text { Proposto } \\
\text { sem RM } \\
\end{array}$ & $\begin{array}{r}3,545 \\
\text { Proposto } \\
\text { sem RM } \\
\end{array}$ & $\begin{array}{r}3,675 \\
\text { Proposto } \\
\text { sem RM } \\
\end{array}$ & $\begin{array}{r}3,160 \\
\text { Proposto } \\
\text { sem RM } \\
\end{array}$ & $\begin{array}{r}2,309 \\
\text { Proposto } \\
\text { sem RM } \\
\end{array}$ & $\begin{array}{r}5,779 \\
\text { Proposto } \\
\text { sem RM }\end{array}$ & $\begin{array}{r}-2,432 \\
\text { Proposto } \\
\end{array}$ \\
\hline
\end{tabular}

Apesar do Coeficiente de Determinação ajustado ( $R^{2}$ ajustado) e os critérios de informação de Akaike e Schwarz indicarem que os modelos Jones e Pae possuem melhores graus de ajustamento comparativamente aos modelos Setorial e Marginal para análise do comportamento do accruals, o teste Vuong evidencia que esses modelos não são os preferíveis.

A escolha entre o modelo Jones e Pae é indiferente. Como destacado anteriormente, a análise comparativa entre os modelos por meio do $R^{2}$ ajustado é dificultada pela falta do intercepto em alguns modelos.

Da mesma forma como ocorreu no contexto chileno, o modelo proposto com ou sem as variáveis de gerenciamento de atividades operacionais tem a mesma capacidade preditiva e são melhores especificações do que os demais modelos concorrentes, conforme evidencia o teste Vuong apresentado na Tabela 43. 
A fim de verificar a contribuição das proxies de gerenciamento das atividades operacionais ao modelo proposto, foram feitos os testes de variáveis redundantes e verificou-se que as variáveis $A b_{-} D O_{i t}$ e $A b_{-} C F O_{i t}$ são relevantes para o modelo (Tabela 44). Observe-se que somente a variável $A b_{-} \operatorname{Prod}_{i t}$ não é significativa, considerando um nível de significância de $5 \%$, e, no caso de sua exclusão do modelo, o $R^{2}$ ajustado seria de 0,431 .

\begin{tabular}{|c|c|c|}
\hline & \multicolumn{2}{|c|}{ log likelihood ratio } \\
\hline & coeficiente & p-value \\
\hline Ab_Prod ${ }_{i t}$ & 3,390 & 0,066 \\
\hline Ab_DO ${ }_{\text {it }}$ & 4,608 & 0,032 \\
\hline $\mathrm{Ab}_{-} \mathrm{CFO}_{\text {it }}$ & 11,305 & 0,001 \\
\hline $\mathrm{Ab}_{-} \operatorname{Prod}_{\mathrm{it}}$ Ab_DO $\mathrm{DO}_{\mathrm{it}}$ & 7,950 & 0,019 \\
\hline Ab_Prod ${ }_{i t}$ Ab_CFO ${ }_{i t}$ & 15,149 & 0,001 \\
\hline $\mathrm{Ab}_{-} \mathrm{DO}_{\text {it }} \quad \mathrm{Ab}_{-} \mathrm{CFO}_{\text {it }}$ & 24,087 & 0,000 \\
\hline 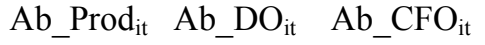 & 28,030 & 0,000 \\
\hline
\end{tabular}

Conforme as evidências apresentadas na Tabela 45, as proxies para capturar o nível de conservadorismo são irrelevantes ao modelo proposto e podem ser retiradas. Quando o modelo proposto é estimado sem as variáveis que controlam o comportamento conservador dos números contábeis, o Coeficiente de Determinação ajustado é de 0,433 , permanecendo, portanto, inadequado em relação à especificação original.

Tabela 45 - Testes de variáveis redundantes para as proxies de conservadorismo - México

\begin{tabular}{|c|c|c|}
\hline & \multicolumn{2}{|c|}{ log likelihood ratio } \\
\hline & coeficiente & p-value \\
\hline$\Delta \mathrm{E}_{\mathrm{t}-1}$ & 1,517 & 0,218 \\
\hline $\mathrm{D} \Delta \mathrm{E}_{\mathrm{it}-1}$ & 0,202 & 0,653 \\
\hline$\Delta \mathrm{E}_{\mathrm{it}-1}{ }^{*} \mathrm{D} \Delta \mathrm{E}_{\mathrm{it}-1}$ & 1,224 & 0,269 \\
\hline $\mathrm{D} \Delta \mathrm{E}_{\mathrm{it}-1}$ & 1,574 & 0,455 \\
\hline$\Delta \mathrm{E}_{\mathrm{t}-1} \quad \Delta \mathrm{E}_{\mathrm{it}-1}{ }^{*} \mathrm{D} \Delta \mathrm{E}_{\mathrm{it}-1}$ & 1,631 & 0,442 \\
\hline $\mathrm{D} \Delta \mathrm{E}_{\mathrm{it}-1} \Delta \mathrm{E}_{\mathrm{it}-1}{ }^{*} \mathrm{D} \Delta \mathrm{E}_{\mathrm{it}-1}$ & 1,402 & 0,496 \\
\hline$\Delta \mathrm{E}_{\mathrm{t}-1} \quad \mathrm{D} \Delta \mathrm{E}_{\mathrm{it}-1} \quad \Delta \mathrm{E}_{\mathrm{it}-1}{ }^{*} \mathrm{D} \Delta \mathrm{E}_{\mathrm{it}-1}$ & 1,713 & 0,634 \\
\hline
\end{tabular}

Esses resultados sugerem que as proxies para controlar o comportamento discricionário nas atividades reais são importantes na estimação dos accruals contábeis, ao passo que o controle do nível de conservadorismo não é significativo na análise do comportamento dos accruals totais.

Analisando-se os testes VIF descritos na Tabela 46, aplicados nos modelos operacionais no contexto mexicano, observa-se que, novamente, os modelos Marginal e Proposto tem problemas de multicolineariedade. Mas, no caso do modelo proposto, as únicas variáveis 
altamente correlacionadas são $R_{i t}$ e $C D_{i t}$. $\mathrm{O}$ teste de variáveis redundantes foi aplicado isoladamente a essas duas variáveis e observou-se que elas são variáveis relevantes ao modelo.

Tabela 46 - Teste de multicolineariedade Variance Inflation Factor no contexto mexicano

\begin{tabular}{|c|c|c|c|c|c|c|c|}
\hline & Jones & KS & Marginal & $\begin{array}{c}\text { Jones } \\
\text { FL } \\
\end{array}$ & Pae & Proposto & $\begin{array}{r}\text { Proposto } \\
\text { (sem RM) }\end{array}$ \\
\hline $1 / A_{i t-1}$ & 1,000 & & & & 1,010 & & \\
\hline$\Delta \mathrm{R}_{\mathrm{it}}$ & 1,258 & & & & 1,313 & & \\
\hline $\mathrm{PPE}_{\mathrm{it}}$ & 1,258 & 1,007 & & 1,207 & 1,683 & & \\
\hline $\mathrm{R}_{\mathrm{it}}$ & & 1,002 & 120,506 & & & 132,708 & 118,883 \\
\hline & & 1,007 & & & & & \\
\hline $\mathrm{R}_{\mathrm{it}}-\Delta \mathrm{CR}_{\mathrm{it}}$ & & & 120,506 & & & & \\
\hline $\begin{array}{l}(1+\mathrm{k}) \Delta \mathrm{R}_{\mathrm{it}}-\Delta \mathrm{CR}_{\mathrm{it}} \\
\mathrm{TA}_{\mathrm{it}-1}\end{array}$ & & & & $\begin{array}{l}1,190 \\
1,025\end{array}$ & 1.071 & 1.120 & 1,085 \\
\hline $\mathrm{CrR}_{\mathrm{it}+1}$ & & & & 1,000 & & & \\
\hline $\mathrm{FCO}_{\text {it }}$ & & & & & 1,690 & 8,163 & 2,272 \\
\hline $\mathrm{FCO}_{\mathrm{it}-1}$ & & & & & 1,600 & & \\
\hline $\mathrm{CD}_{\mathrm{it}}$ & & & & & & 124,862 & 112,938 \\
\hline $\mathrm{AI}_{\mathrm{it}}$ & & & & & & 1,891 & 1,614 \\
\hline $\mathrm{AD}_{\text {it }}$ & & & & & & 1,410 & 1,330 \\
\hline$E_{\text {it }}$ & & & & & & 2,645 & 2,515 \\
\hline $\mathrm{E}_{\mathrm{it}}^{2}$ & & & & & & 2,456 & 2,314 \\
\hline$\Delta \mathrm{E}_{\mathrm{t}-1}$ & & & & & & 4,450 & 3,965 \\
\hline $\mathrm{D} \Delta \mathrm{E}_{\mathrm{it}-1}$ & & & & & & 1,173 & 1,169 \\
\hline$\Delta \mathrm{E}_{\mathrm{it}-1}{ }^{*} \mathrm{D} \Delta \mathrm{E}_{\mathrm{it}-1}$ & & & & & & 3,511 & 3,385 \\
\hline Ab_Prod ${ }_{i t}$ & & & & & & 1,126 & \\
\hline Ab_DO ${ }_{\text {it }}$ & & & & & & 1,214 & \\
\hline $\mathrm{Ab} \_\mathrm{CFO} \mathrm{it}_{\text {it }}$ & & & & & & 6,314 & \\
\hline
\end{tabular}

Assim como no Brasil, o teste KMO com a amostra mexicana foi de 0,504 (Tabela 47), indicando que a análise fatorial não descreve adequadamente as variações das variáveis originais. Pela Correlação da Matriz Anti-Imagem (Apêndice 102), também, verificam-se diversas variáveis como o MSA inferior a 0,500.

Tabela 47 - KMO and Bartlett's Test - México

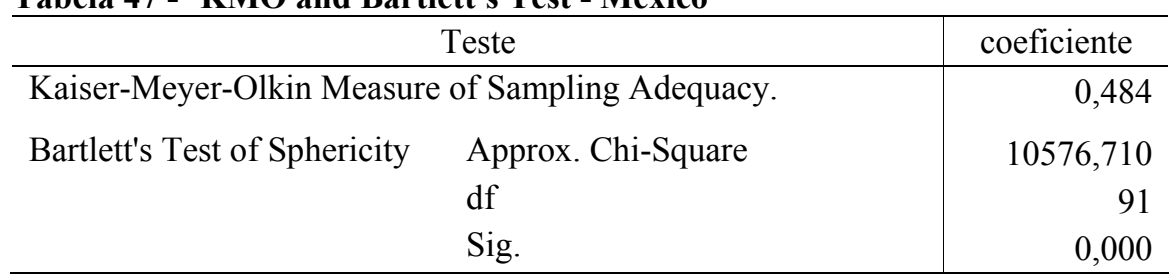




\subsubsection{Peru}

Assim como ocorre nas amostras com as companhias abertas brasileiras, chilenas e mexicanas, os resíduos dos modelos operacionais para estimação do accruals não seguem uma distribuição normal no ambiente peruano (Tabelas 48 a 50). Como demonstrado nos Apêndices 1 e 2, não existe forte correlação entre os resíduos e as variáveis explicativas, portanto, todos os modelos no ambiente peruano atendem o pressuposto da exogeneidade.

O modelo Setorial, aplicado ao contexto peruano, não atende a hipótese de homoscedasticidade, mas seus resíduos não têm autocorrelação. Apesar de a estatística $F$ informar que a variável mediana dos accruals totais explica o comportamento dos accruals totais, o modelo apresenta um baixo poder de explicação $\left(R^{2}=0,021\right)$.

O modelo Jones (1991) tem um $R^{2}$ mais elevado $(0,180)$ do que o modelo Setorial, porém os testes detectaram presença de heteroscedasticidade e de correlação serial. Observe-se que para essa amostra, nenhuma variável é significativamente diferente de zero.

Diferentemente dos demais modelos, o KS estimado através do método de variáveis instrumentais (IV) não apresenta problemas de heteroscedasticidade e autocorrelação, mas o seu $R^{2}$ cai em relação ao modelo Jones $(0,070)$ e a estatística $F$ evidencia que o modelo não explica a variação dos accruals totais e as variáveis explicativas não são estatisticamente diferentes de zero.

Tabela 48 - Estimação dos modelos operacionais no contexto peruano - Parte A

\begin{tabular}{|c|c|c|c|c|c|c|}
\hline & \multicolumn{2}{|c|}{ Setorial } & \multicolumn{2}{|c|}{ Jones } & \multicolumn{2}{|c|}{ KS IV } \\
\hline & coeficiente & p-value & coeficiente & p-value & coeficiente & p-value \\
\hline Constante & 0,032 & 0,121 & & & $-0,014$ & 0,657 \\
\hline Mediana TA & 1,866 & 0,009 & & & & \\
\hline $1 / A_{i t-1}$ & & & 1413,661 & 0,243 & & \\
\hline$\Delta \mathrm{R}_{\mathrm{it}}$ & & & 0,200 & 0,079 & & \\
\hline $\mathrm{PPE}_{\mathrm{it}}$ & & & $-0,171$ & 0,237 & $-0,614$ & 0,299 \\
\hline $\mathrm{R}_{\mathrm{it}}$ & & & & & 0,019 & 0,814 \\
\hline $\mathrm{D}_{\mathrm{it}}$ & & & & & 0,095 & 0,118 \\
\hline$R^{2}$ & 0,021 & & 0,180 & & 0,070 & \\
\hline$R^{2}$ ajustado & 0,020 & & 0,165 & & 0,025 & \\
\hline Akaike criterion & 0,344 & & 0,176 & & $-1,872$ & \\
\hline Schwarz criterion & 0,354 & & 0,267 & & $-1,740$ & \\
\hline Estatística $F$ & 21,065 & 0,000 & & & 1.564 & 0,207 \\
\hline White Heteroskedasticity & & & & & & \\
\hline Test & 10,486 & 0,005 & 932,100 & 0,000 & 3,893 & 0,918 \\
\hline KB Test & 28,084 & 0,001 & 1,349 & 0,000 & $-1,459$ & 0,651 \\
\hline Durbin-Watson & 2,089 & & 2,013 & & 2,487 & \\
\hline Breusch-Godfrey Serial & & & & & & \\
\hline Correlation LM Test & 5,413 & 0,067 & 6,667 & 0,035 & 3,701 & 0,157 \\
\hline Jarque-Bera Test & 1030498 & 0,000 & 753996,200 & 0,000 & 11,491 & 0,003 \\
\hline Observações & 981 & & 961 & & 947 & \\
\hline
\end{tabular}


$\mathrm{O}$ único setor com $\beta$ significativo no modelo Jones foi o de telecomunicações $(-0,251)$, enquanto o KS não teve nenhum coeficiente setorial significativo.

O modelo KS MQO (Tabela 49) apresenta um $R^{2}$ ajustado $(0,172)$ maior do que estimado por VI $(0,070)$, porém os testes de Akaike e Schwarz indicam que a melhor estimação é pelo método IV. O modelo KS pelo MQO não apresenta correlação serial, entretanto, os coeficientes $\beta$ 's não são significativamente diferentes de zero e os resíduos são heteroscedásticos.

Tabela 49 - Estimação dos modelos operacionais no contexto peruano - Parte B

\begin{tabular}{|c|c|c|c|c|c|c|}
\hline & \multicolumn{2}{|c|}{ KS MQO } & \multicolumn{2}{|c|}{ Marginal } & \multicolumn{2}{|c|}{ Jones FL } \\
\hline & coeficiente & p-value & coeficiente & p-value & coeficiente & p-value \\
\hline Constante & $-0,063$ & 0,582 & $-0,106$ & 0,088 & $-0,083$ & 0,005 \\
\hline $\mathrm{R}_{\mathrm{it}}$ & 0,129 & 0,189 & $-0,284$ & 0,485 & & \\
\hline $\mathrm{D}_{\mathrm{it}}$ & 0,032 & 0,570 & & & & \\
\hline $\mathrm{PPE}_{\mathrm{it}}$ & $-0,141$ & 0,505 & & & 0,085 & 0,146 \\
\hline $\mathrm{R}_{\mathrm{it}}-\Delta \mathrm{CR}_{\mathrm{it}}$ & & & 0,417 & 0,295 & & \\
\hline$(1+\mathrm{k}) \Delta \mathrm{R}_{\mathrm{it}}-\Delta \mathrm{CR}_{\mathrm{it}}$ & & & & & 0,206 & 0,001 \\
\hline $\mathrm{TA}_{\mathrm{it}-1}$ & & & & & $-0,050$ & 0,304 \\
\hline $\mathrm{CrR}_{\mathrm{it}+1}$ & & & & & 0,000 & 0,152 \\
\hline$R^{2}$ & 0,172 & & 0,161 & & 0,387 & \\
\hline$R^{2}$ ajustado & 0,156 & & 0,146 & & 0,372 & \\
\hline Akaike criterion & 0,205 & & 0,215 & & $-0,313$ & \\
\hline Schwarz criterion & 0,300 & & 0,306 & & $-0,193$ & \\
\hline Estatística $F$ & 10,894 & 0,000 & 10,685 & 0,000 & 25,085 & 0,000 \\
\hline White Heteroskedasticity & & & & & & \\
\hline Test & 937,260 & 0,000 & 902,890 & 0,000 & 614,064 & 0,000 \\
\hline KB Test & 2,456 & 0,000 & 1,331 & 0,000 & 0,092 & 0,000 \\
\hline Durbin-Watson & 1,961 & & 2,040 & & 1,968 & \\
\hline Breusch-Godfrey Serial & & & & & & \\
\hline Correlation LM Test & 3,802 & 0,149 & 2,990 & 0,224 & 5,347 & 0,069 \\
\hline Jarque-Bera Test & 660613,000 & 0,000 & 814510 & & 84895,920 & 0,000 \\
\hline Observações & 965 & & 965 & & 775 & \\
\hline
\end{tabular}

O modelo Marginal apresenta características semelhantes às estimativas dos parâmetros do KS MQO, tendo o $R^{2}$ de 0,161 , os coeficientes $\beta$ 's não são significativamente diferentes de zero e os resíduos são heteroscedásticos e não autocorrelacionados. Segundo demonstrado na Tabela 56, esse modelo apresenta multicolineariedade entre as suas variáveis, o que afeta a significância dos coeficientes.

Com relação ao modelo Jones Forward Looking, os resultados, apresentados na Tabela 49, indicam que os resíduos não apresentam autocorrelação, mas são heteroscedásticos. Porém essa especificação tem um maior nível de ajustado do que os modelos anteriormente analisados no contexto peruano, sendo que seu Coeficiente de Determinação $\left(R^{2}\right)$ é de 0,387 . Todavia, o única variável que possui um coeficiente significativamente diferente de zero é a 
variável que representa a diferença entre a variação das receitas líquidas e das contas a receber ajustada pelo fator de correção $\left((1+k) \Delta R_{i t}-\Delta C R_{i t}\right)$.

Para o modelo KS MQO, os setores com coeficiente significativo foram o de petróleo e gás $(0,226)$ e o de telecomunicações $(-0,308)$, enquanto para o modelo Jones $\mathrm{Fl}$, somente o de telecomunicações $(-0,127)$.

Tabela 50 - Estimação dos modelos operacionais no contexto peruano - Parte C

\begin{tabular}{|c|c|c|c|c|c|c|}
\hline & \multicolumn{2}{|c|}{ Pae } & \multicolumn{2}{|c|}{ Proposto } & \multicolumn{2}{|c|}{ Proposto (sem RM) } \\
\hline & coeficiente & p-value & coeficiente & p-value & coeficiente & p-value \\
\hline Constante & & & 0,051 & 0,235 & 0,070 & 0,222 \\
\hline $1 / A_{i t-1}$ & 1193,191 & 0,380 & & & & \\
\hline$\Delta \mathrm{R}_{\mathrm{it}}$ & 0,211 & 0,090 & & & & \\
\hline $\mathrm{PPE}_{\mathrm{it}}$ & $-0,182$ & 0,155 & & & & \\
\hline $\mathrm{FCO}_{\mathrm{it}}$ & $-0,026$ & 0,791 & $-1,427$ & 0,000 & $-1,105$ & 0,000 \\
\hline $\mathrm{FCO}_{\text {it-1 }}$ & 0,004 & 0,953 & & & & \\
\hline $\mathrm{TA}_{\mathrm{it}-1}$ & 0,006 & 0,940 & $-0,040$ & 0,233 & $-0,049$ & 0,016 \\
\hline $\mathrm{R}_{\mathrm{it}}$ & & & 0,685 & 0,000 & 0,595 & 0,003 \\
\hline $\mathrm{CD}_{\text {it }}$ & & & $-0,771$ & 0,000 & $-0,605$ & 0,007 \\
\hline $\mathrm{AI}_{\mathrm{it}}$ & & & $-0,190$ & 0,009 & $-0,192$ & 0,046 \\
\hline $\mathrm{AD}_{\text {it }}$ & & & 0,143 & 0,305 & 0,111 & 0,480 \\
\hline $\mathrm{E}_{\mathrm{it}}$ & & & 0,505 & 0,000 & 0,588 & 0,001 \\
\hline$E_{i t}^{2}$ & & & $-0,605$ & 0,107 & $-0,073$ & 0,832 \\
\hline$\Delta \mathrm{E}_{\mathrm{t}-1}$ & & & 0,147 & 0,217 & 0,139 & 0,217 \\
\hline $\mathrm{D} \Delta \mathrm{E}_{\mathrm{it}-1}$ & & & $-0,001$ & 0,938 & $-0,018$ & 0,187 \\
\hline$\Delta \mathrm{E}_{\mathrm{it}-1}{ }^{*} \mathrm{D} \Delta \mathrm{E}_{\mathrm{it}-1}$ & & & $-0,302$ & 0,208 & $-0,314$ & 0,209 \\
\hline $\mathrm{Ab}$ Prod $_{\mathrm{it}}$ & & & 0,209 & 0,005 & & \\
\hline $\mathrm{Ab} \_\mathrm{DO}_{i t}$ & & & $-0,050$ & 0,036 & & \\
\hline $\mathrm{Ab}_{-} \mathrm{CFO}_{\text {it }}$ & & & 0,495 & 0,008 & & \\
\hline$R^{2}$ & 0,200 & & 0,741 & & 0,679 & \\
\hline$R^{2}$ ajustado & 0,182 & & 0,732 & & 0,670 & \\
\hline Akaike criterion & 0,199 & & $-0,977$ & & $-0,778$ & \\
\hline Schwarz criterion & 0,311 & & $-0,811$ & & $-0,633$ & \\
\hline Estatística $F$ & & & 81,895 & 0,000 & 70,61282 & 0,000 \\
\hline White Heteroskedasticity & & & & & & \\
\hline Test & 891,507 & 0,000 & 693,268 & 0,000 & 776,715 & 0,000 \\
\hline Teste $K B$ & 0,964 & 0,000 & 0,030 & 0,000 & 0,071 & 0,000 \\
\hline Durbin-Watson & 2,029 & & 1,849 & & 1,808 & \\
\hline Breusch-Godfrey Serial & & & & & & \\
\hline Correlation LM Test & 12,283 & 0,002 & 6,417 & 0,040 & 2,792 & 0,094 \\
\hline Jarque-Bera Test & 694071 & 0,000 & 13267,020 & 0,000 & 42141,320 & 0,000 \\
\hline Observações & 901 & & 861 & & 893 & \\
\hline
\end{tabular}

O modelo Pae tem presença de autocorrelação e de heteroscedasticidade, com um grau de ajuste inferior ao Jone Forward Looking, pois o seu $R^{2}$ é igual a 0,200 e nenhuma variável tem coeficiente diferente de zero. Somente o setor de telecomunicações $(-0,253)$ teve coeficiente significativo.

Já o modelo proposto apresenta heteroscedasticidade e autocorrelação, tendo um $R^{2}$ de 0,741 , o que indica que possui um elevado grau de ajuste e, conseqüentemente, explica de forma satisfatória o comportamento dos accruals totais das companhias abertas peruanas. Porém, as 
variáveis $T A_{i t}, A D_{i t}, E^{2}{ }_{i t}$ e as proxies do nível de conservadorismo não são estatisticamente diferentes de zero. As demais variáveis são significantes e têm os sinais esperados, exceto o coeficiente da proxy para comportamento anormal das despesas operacionais.

As mesmas características das estimativas ocorrem no modelo proposto sem controlar gerenciamento das atividades operacionais, exceto pelo fato dos resíduos não serem autocorrelacionados e a variável $T A_{i t}$ passa ter um coeficiente estatisticamente diferentes de zero. Porém, o grau de ajuste decresce, pois o $R^{2}$ assume o valor de 0,679 .

No modelo proposto, somente os setores de construção, petróleo e gás e telecomunicações não apresentam coeficientes significativos. Os setores com coeficientes significativos foram: agropecuária e pesca $(0,112)$, alimentos e bebidas $(0,125)$, comércio $(0,165)$, eletroeletrônicos $(0,110)$, energia elétrica $(0,154)$, máquinas industriais $(0,074)$, mineração $(0,096)$, minerais não-metálicos $(0,132)$, química $(0,108)$, siderurgia e metalurgia $(0,138)$, têxtil $(0,102)$ e veículos e peças $(-0,127)$.

Na Tabela 51, são apresentadas as estimações dos parâmetros e dos testes estatísticos para as proxies de gerenciamento dos resultados contábeis através das atividades operacionais. Observe-se que todas as regressões têm presença de heteroscedasticidade e autocorrelação.

Tabela 51 - Gerenciamento de atividades operacionais no contexto peruano

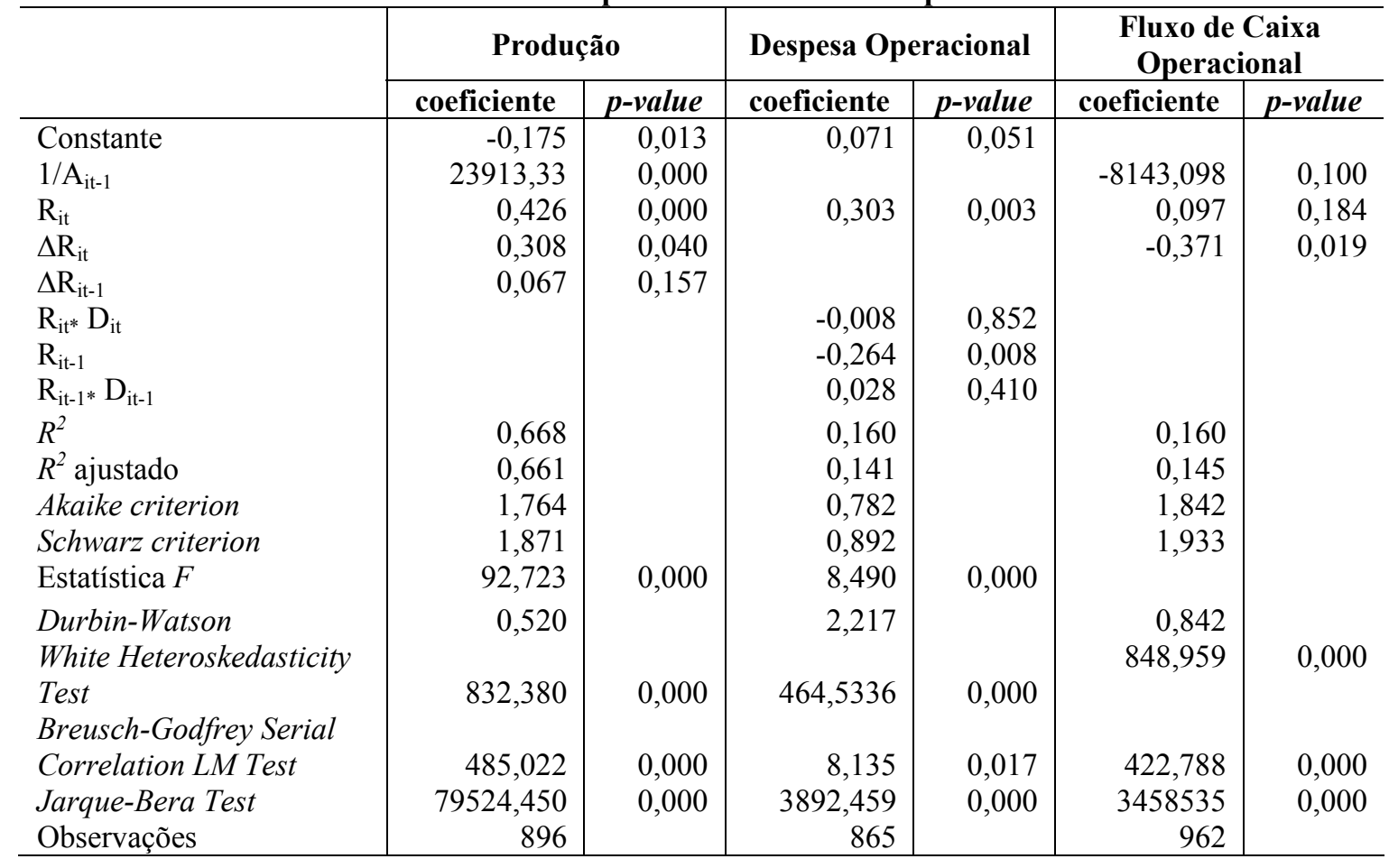


O modelo para capturar o comportamento anormal da produção tem maior nível de ajuste $\left(R^{2}=0,668\right)$ do que os modelos das despesas operacionais $\left(R^{2}=0,160\right)$ e do fluxo de caixa $\left(R^{2}=0,160\right)$.

Tabela 52 - Comparação do ajuste dos modelos operacionais no contexto peruano

\begin{tabular}{l|r|r|r}
\hline \multicolumn{1}{c|}{ Modelos } & $\mathbf{R}^{2}$ ajustado & \multicolumn{1}{c}{ Akaike } & \multicolumn{1}{c}{ Schwarz } \\
\hline Setorial & 0,020 & 0,344 & 0,354 \\
Jones & 0,165 & 0,176 & 0,267 \\
KS (IV) & 0,070 & $-1,872$ & $-1,740$ \\
KS (MQO) & 0,156 & 0,205 & 0,300 \\
Marginal & 0,146 & 0,215 & 0,306 \\
Jones Forward Looking & 0,372 & $-0,313$ & $-0,193$ \\
Pae & 0,200 & 0,199 & 0,311 \\
Proposto & 0,732 & $-0,977$ & $-0,811$ \\
Proposto (sem manipulação real) & 0,670 & $-0,778$ & $-0,633$ \\
\hline
\end{tabular}

Observe-se, na Tabela 52, que, no contexto peruano, o modelo proposto é mais bem especificado do que os demais modelos operacionais para a estimação dos accruals discricionários utilizados para detecção de gerenciamento de resultados. Essa mesma evidencia é corroborada pelo teste Vuong apresentado na Tabela 53.

Tabela 53 - Comparação do ajuste dos modelos operacionais no contexto peruano através do teste Vuong (nonnested model)

\begin{tabular}{|c|c|c|c|c|c|c|c|c|}
\hline Modelo & Setorial & Jones & KS & $\begin{array}{c}\text { KS } \\
\text { MQO }\end{array}$ & $\begin{array}{c}\text { Margi- } \\
\text { nal }\end{array}$ & JonesFL & Pae & $\begin{array}{c}\text { Propos- } \\
\text { to }\end{array}$ \\
\hline Jones & $\begin{array}{l}6,036 \\
\text { Jones }\end{array}$ & & & & & & & \\
\hline $\mathrm{KS}$ & $\begin{array}{l}-1,555 \\
\text { Indife- } \\
\text { rente }\end{array}$ & $\begin{array}{l}-1,978 \\
\text { Jones }\end{array}$ & & & & & & \\
\hline KS MQO & $\begin{array}{c}2,279 \\
\mathrm{KS} \\
\mathrm{MQO}\end{array}$ & $\begin{array}{c}-1,309 \\
\text { Indife- } \\
\text { rente }\end{array}$ & $\begin{array}{c}1,572 \\
\text { Indife- } \\
\text { rente }\end{array}$ & & & & & \\
\hline Marginal & $\begin{array}{r}2,278 \\
\text { Marginal } \\
\end{array}$ & $\begin{array}{l}-4,407 \\
\text { Jones }\end{array}$ & $\begin{array}{c}1,559 \\
\text { Indife- } \\
\text { rente }\end{array}$ & $\begin{array}{c}0,108 \\
\text { Indife- } \\
\text { rente }\end{array}$ & & & & \\
\hline JonesFL & $\begin{array}{r}4,184 \\
\text { JonesFL }\end{array}$ & $\begin{array}{r}2,952 \\
\text { JonesFL }\end{array}$ & $\begin{array}{c}0,994 \\
\text { Indife- } \\
\text { rente }\end{array}$ & $\begin{array}{r}3,808 \\
\text { JonesFL }\end{array}$ & $\begin{array}{r}3,985 \\
\text { JonesFL }\end{array}$ & & & \\
\hline $\mathrm{Pae}$ & $\begin{array}{l}2,611 \\
\mathrm{Pae} \\
\end{array}$ & $\begin{array}{l}-2,961 \\
\text { Jones }\end{array}$ & $\begin{array}{c}1,242 \\
\text { Indife- } \\
\text { rente }\end{array}$ & $\begin{array}{c}-0,691 \\
\text { Indife- } \\
\text { rente }\end{array}$ & $\begin{array}{c}-0,474 \\
\text { Indife- } \\
\text { rente } \\
\end{array}$ & $\begin{array}{r}-4,513 \\
\text { JonesFL }\end{array}$ & & \\
\hline Proposto & $\begin{array}{r}2,971 \\
\text { Proposto } \\
\end{array}$ & $\begin{array}{r}2,898 \\
\text { Proposto } \\
\end{array}$ & $\begin{array}{r}3,115 \\
\text { Proposto } \\
\end{array}$ & $\begin{array}{r}2,581 \\
\text { Proposto } \\
\end{array}$ & $\begin{array}{r}3,378 \\
\text { Proposto } \\
\end{array}$ & $\begin{array}{r}2,129 \\
\text { Proposto } \\
\end{array}$ & $\begin{array}{r}2,957 \\
\text { Proposto } \\
\end{array}$ & \\
\hline $\begin{array}{l}\text { Proposto } \\
\text { sem RM }\end{array}$ & $\begin{array}{r}4,728 \\
\text { Proposto } \\
\text { sem RM }\end{array}$ & $\begin{array}{r}3,201 \\
\text { Proposto } \\
\text { sem RM }\end{array}$ & $\begin{array}{r}3241 \\
\text { Proposto } \\
\text { sem RM }\end{array}$ & $\begin{array}{r}4,437 \\
\text { Proposto } \\
\text { sem RM }\end{array}$ & $\begin{array}{r}4,151 \\
\text { Proposto } \\
\text { sem RM }\end{array}$ & $\begin{array}{r}2,070 \\
\text { Proposto } \\
\text { sem RM }\end{array}$ & $\begin{array}{r}4,767 \\
\text { Proposto } \\
\text { sem RM }\end{array}$ & $\begin{array}{c}1,637 \\
\text { Indife- } \\
\text { rente }\end{array}$ \\
\hline
\end{tabular}


Analisando-se a contribuição das proxies de gerenciamento das atividades operacionais ao modelo proposto (Tabela 54), verificou-se que todas as variáveis são relevantes para o modelo, contribuindo significativamente para a predição do comportamento dos accruals.

Tabela 54 - Testes de variáveis redundantes para as proxies de gerenciamento de atividades operacionais - Peru

\begin{tabular}{|c|c|c|}
\hline \multicolumn{3}{|c|}{ log likelihood ratio } \\
\hline & Coeficiente & p-value \\
\hline Ab_Prod ${ }_{i t}$ & 83,691 & 0,000 \\
\hline $\mathrm{Ab} \mathrm{DOO}_{\mathrm{it}}$ & 11,047 & 0,001 \\
\hline $\mathrm{Ab} \mathrm{CFO}_{\text {it }}$ & 59,128 & 0,000 \\
\hline $\mathrm{Ab}{ }_{-}$Prod $_{\mathrm{it}}$ Ab_DO $\mathrm{DO}_{\mathrm{it}}$ & 94,945 & 0,000 \\
\hline $\mathrm{Ab}_{-} \operatorname{Prod}_{\mathrm{it}} \mathrm{Ab} \mathrm{C}_{-} \mathrm{CFO}_{\mathrm{it}}$ & 83,765 & 0,000 \\
\hline $\mathrm{Ab}_{-} \mathrm{DO}_{\mathrm{it}} \mathrm{Ab} \mathrm{C}_{-} \mathrm{CFO} \mathrm{O}_{\mathrm{it}}$ & 66,478 & 0,000 \\
\hline $\mathrm{Ab}_{-} \operatorname{Prod}_{\mathrm{it}} \mathrm{A} \overline{\mathrm{b}} \_\mathrm{DO}_{\mathrm{it}} \quad \mathrm{Ab}_{-} \mathrm{CFO}_{\mathrm{it}}$ & 94,526 & 0,000 \\
\hline
\end{tabular}

Conforme as evidências apresentadas na Tabela 55, as proxies para capturar o nível de conservadorismo não são relevantes ao modelo, portanto, não afetam a estimação dos accruals. Quando da extração do conjunto de variáveis que formam a proxy para capturar o nível de conservadorismo, o coeficiente de determinação $\left(R^{2}\right)$ é de 0,740 , portanto, não altera significativamente o grau de ajustamento do modelo.

Tabela 55 - Testes de variáveis redundantes para as proxies de conservadorismo - Peru

\begin{tabular}{|c|c|c|}
\hline \multicolumn{3}{|c|}{ log likelihood ratio } \\
\hline & coeficiente & p-value \\
\hline$\Delta \mathrm{E}_{\mathrm{t}-1}$ & 2,005 & 0,157 \\
\hline $\mathrm{D} \Delta \mathrm{E}_{\mathrm{it}-1}$ & 0,005 & 0,944 \\
\hline$\Delta \mathrm{E}_{\mathrm{it}-1}{ }^{*} \mathrm{D} \Delta \mathrm{E}_{\mathrm{it}-1}$ & 2,152 & 0,142 \\
\hline$\Delta \mathrm{E}_{\mathrm{t}-1} \quad \mathrm{D} \Delta \mathrm{E}_{\mathrm{it}-1}$ & 2,285 & 0,319 \\
\hline$\Delta \mathrm{E}_{\mathrm{it}-1}^{*} \mathrm{D} \Delta \mathrm{E}_{\mathrm{it}-1}$ & 2,603 & 0,272 \\
\hline $\mathrm{D} \Delta \mathrm{E}_{\mathrm{it}-1} \Delta \mathrm{E}_{\mathrm{it}-1}^{*} \mathrm{D} \Delta \mathrm{E}_{\mathrm{it}-1}$ & 2,171 & 0,338 \\
\hline$\Delta \mathrm{E}_{\mathrm{t}-1} \quad \mathrm{D} \Delta \mathrm{E}_{\mathrm{it}-1} \quad \Delta \mathrm{E}_{\mathrm{it}-1}{ }^{*} \mathrm{D} \Delta \mathrm{E}_{\mathrm{it}-1}$ & 2,651 & 0,449 \\
\hline
\end{tabular}

Conforme o teste Variance Inflation Factor (Tabela 56), novamente os modelos Marginal e Proposto apresentam problemas de multicolineariedade na especificação. O problema de multicolineariedade, no modelo proposto, deve-se à alta correlação entre as variáveis $\mathrm{R}_{\mathrm{it}} \mathrm{e}$ $\mathrm{CD}_{\text {it, }}$ mas quando aplicado o teste de variáveis redundantes, essas variáveis, mesmo isoladas, são significativas para o modelo proposto. 
Tabela 56 - Teste de multicolineariedade Variance Inflation Factor no contexto peruano

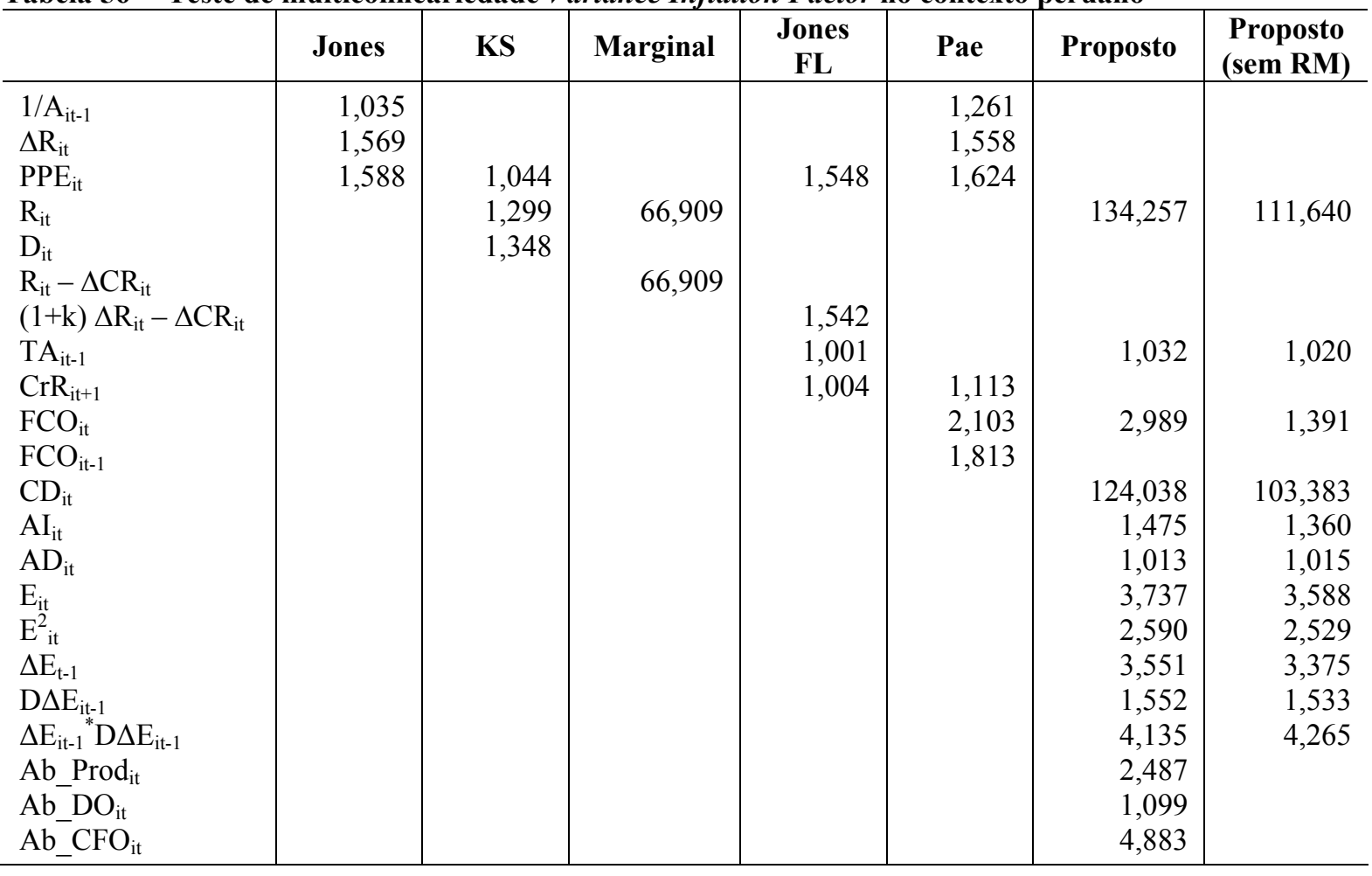

No caso de exclusão da variável $C D_{i t}$, o Coeficiente de Determinação ajustado assume o valor de 0,700 , mas o modelo continua apresentando os problemas de heteroscedasticidade e correlação serial.

Semelhante ao ocorrido nas amostras anteriores, o teste KMO com a amostra peruana foi de 0,553, indicando que a análise fatorial não descreve adequadamente as variações das variáveis originais. Pela Correlação da Matriz Anti-Imagem (Apêndice 130), também, verifica-se que existem variáveis com MSA inferiores a 0,500 .

Tabela 57 - KMO and Bartlett's Test - Peru

\begin{tabular}{|c|c|c|}
\hline \multicolumn{2}{|c|}{ Teste } & coeficiente \\
\hline \multicolumn{2}{|c|}{ Kaiser-Meyer-Olkin Measure of Sampling Adequacy. } & 0,553 \\
\hline \multirow[t]{3}{*}{ Bartlett's Test of Sphericity } & Approx. Chi-Square & 8343,325 \\
\hline & df & 91 \\
\hline & Sig. & 0,000 \\
\hline
\end{tabular}

Da mesma forma que no Chile, foi efetuada uma segunda tentativa, eliminando as variáveis com MSA inferior a 0,500 na primeira tentativa. Com isso, o KMO se elevou um pouco (0,566), mas a Correlação da Matriz Anti-Imagem (Apêndice 131), apresentou mais variáveis com MSA inferior a 0,500 , o que limitou novas tentativas. 


\subsubsection{Estados Unidos da América}

As tabelas 58 a 60 apresentam as estimações dos parâmetros e testes estatísticos de cada modelo para as companhias norte-americanas. Assim como observado nas amostras anteriores, nesse ambiente, todos os modelos operacionais analisados neste trabalho rejeitam a hipótese nula de normalidade. Igualmente aos demais ambientes econômicos, todos os modelos nesse ambiente econômico atendem o pressuposto da exogeneidade (Apêndices 1 e 2).

Segundo as evidências apresentadas na Tabela 58, as estimações dos modelos Setorial, Jones e KS aplicados no contexto das companhias dos EUA não atendem às hipóteses de homoscedasticidade e ausência de autocorrelação. Cabe observar que, pelo teste KB, os modelos Setorial e KS apresentam resíduos homoscedásticos, portanto, a análise com base nesse pressuposto deve considerada com cautela.

Tabela 58 - Estimação dos modelos operacionais no contexto norte-americano - Parte A

\begin{tabular}{|c|c|c|c|c|c|c|}
\hline & \multicolumn{2}{|c|}{ Setorial } & \multicolumn{2}{|c|}{ Jones } & \multicolumn{2}{|c|}{ KS } \\
\hline & coeficiente & p-value & coeficiente & p-value & Coeficiente & p-value \\
\hline Constante & 0,021 & 0,000 & & & $-00,49$ & 0,000 \\
\hline Mediana TA & 1,584 & 0,000 & & & & \\
\hline $1 / A_{\text {it- } 1}$ & & & $-1424,847$ & 0,273 & & \\
\hline$\Delta \mathrm{R}_{\mathrm{it}}$ & & & $-0,012$ & 0,782 & & \\
\hline $\mathrm{PPE}_{\mathrm{it}}$ & & & $-0,075$ & 0,000 & $-0,000$ & 0,233 \\
\hline $\mathrm{R}_{\mathrm{it}}$ & & & & & 0,001 & 0,000 \\
\hline $\mathrm{D}_{\mathrm{it}}$ & & & & & -0.000 & 0,000 \\
\hline$R^{2}$ & 0,037 & & 0,045 & & 0,056 & \\
\hline$R^{2}$ ajustado & 0,036 & & 0,043 & & 0.053 & \\
\hline Akaike criterion & $-1,305$ & & $-1,267$ & & $-1,387$ & \\
\hline Schwarz criterion & $-1,303$ & & $-1,247$ & & $-1,363$ & \\
\hline Estatística $F$ & 292,606 & 0,000 & & & 17,788 & 0,000 \\
\hline White Heteroskedasticity & & & & & & \\
\hline Test & 6,637 & 0,036 & 3278,867 & 0,000 & 1353,377 & 0,000 \\
\hline KB Test & 0,693 & 0,578 & 4,916 & 0,000 & 0,854 & 0,101 \\
\hline Durbin-Watson & 1,702 & & 1,672 & & 1,749 & \\
\hline Breusch-Godfrey Serial & & & & & & \\
\hline Correlation LM Test & 232,913 & 0,000 & 195,545 & 0,000 & 77,879 & 0,000 \\
\hline Jarque-Bera Test & 14505250 & 0,000 & 8662633 & 0,000 & 6417849 & 0,000 \\
\hline Observações & 7555 & & 7090 & & 6327 & \\
\hline
\end{tabular}

O modelo Setorial apresenta um $\mathrm{R}^{2}$ de 0,037 , sendo considerado como um baixo poder de explicação, mas os resultados do teste $t$ para os coeficientes e da estatística $F$ indicam que a variável preditora desse modelo explica o comportamento dos accruals totais.

O modelo Jones possui as mesmas características do modelo Setorial, com o $R^{2}$ de 0,045 e com os resíduos autocorrelacionados e heteroscedásticos. A única variável que apresenta 
coeficiente significativo é a variável que representa o ativo imobilizado e o diferido líquido e tem o sinal esperado. Pelo critérios de Akaike e Schwarz, o modelo Setorial é o preferível em relação ao Jones.

O modelo KS estimado, também, apresenta problemas com relação à heteroscedasticidade e autocorrelação, e tem um $R^{2}$ considerado baixo $(0,056)$. Diferentemente do modelo Jones, a variável $P P E_{i t}$ não apresenta o coeficiente significativamente diferente de zero, ao passo que as demais variáveis são significativas para a predição do comportamento dos accruals nesse modelo, e os sinais são aqueles esperados para o modelo.

Com relação aos setores com coeficientes significativos, o modelo Jones teve construção $(0,095)$, software e dados $(-0,066)$ e telecomunicações $(-0,051)$. O modelo KS apresentou os setores comércio $(0,057)$, construção $(0,108)$ e telecomunicações $(-0,045)$.

Analisando-se as estimativas para os modelos KS MQO, Marginal e Jones Forward Looking constantes da Tabela 59, verifica-se o mesmo comportamento em relação aos pressupostos da regressão, ou seja, não atendem às hipóteses de homoscedasticidade, ausência de autocorrelação e de normalidade.

Tabela 59 - Estimação dos modelos operacionais no contexto norte-americano - Parte B

\begin{tabular}{|c|c|c|c|c|c|c|}
\hline & \multicolumn{2}{|c|}{ KS MQO } & \multicolumn{2}{|c|}{ Marginal } & \multicolumn{2}{|c|}{ Jones FL } \\
\hline & coeficiente & p-value & coeficiente & p-value & coeficiente & p-value \\
\hline Constante & $-0,046$ & 0,0001 & $-0,037$ & 0,001 & $-0,029$ & 0,000 \\
\hline $\mathrm{R}_{\mathrm{it}}$ & 0,246 & 0,0000 & 0,425 & 0,000 & & \\
\hline $\mathrm{D}_{\text {it }}$ & $-0,270$ & 0,0000 & & & & \\
\hline $\mathrm{PPE}_{\mathrm{it}}$ & $-0,058$ & 0,0000 & & & -0.043 & 0,000 \\
\hline $\mathrm{R}_{\mathrm{it}}-\Delta \mathrm{CR}_{\mathrm{it}}$ & & & $-0,452$ & 0,000 & & \\
\hline$(1+\mathrm{k}) \Delta \mathrm{R}_{\mathrm{it}}-\Delta \mathrm{CR}_{\mathrm{it}}$ & & & & & $-0,001$ & 0,904 \\
\hline $\mathrm{TA}_{\mathrm{it}-1}$ & & & & & 0,136 & 0,000 \\
\hline $\mathrm{CrR}_{\mathrm{it}+1}$ & & & & & $2,44 \mathrm{E}-05$ & 0,000 \\
\hline$R^{2}$ & 0,233 & & 0,096 & & 0,101 & \\
\hline$R^{2}$ ajustado & 0,231 & & 0,093 & & 0,097 & \\
\hline Akaike criterion & $-1,423$ & & $-1,361$ & & $-1,742$ & \\
\hline Schwarz criterion & $-1,400$ & & $-1,341$ & & $-1,713$ & \\
\hline Estatística $F$ & 95,162 & 0,000 & 39,776 & 0,000 & 26,949 & 0,000 \\
\hline White Heteroskedasticity & & & & & & \\
\hline Test & 3681,826 & 0,000 & 2901,343 & 0,000 & 310,234 & 0,000 \\
\hline KB Test & 0,525 & 0,000 & 3,353 & 0,000 & 0,308 & 0,009 \\
\hline Durbin-Watson & 1,643 & & 1,722 & & 1,951 & \\
\hline Breusch-Godfrey Serial & & & & & & \\
\hline Correlation LM Test & 237,325 & 0,000 & 208,427 & 0,000 & 9,461 & 0,009 \\
\hline Jarque-Bera Test & 1834387 & 0,000 & 15338805 & 0,000 & 685327 & 0,000 \\
\hline Observações & 6591 & & 7540 & & 5286 & \\
\hline
\end{tabular}

Através da estimação pelo MQO, o modelo KS apresenta um grau de ajustamento superior ao KS pelo método IV. Nessa estimação, a variável $P P E_{i t}$ tem o coeficiente $\beta$ diferente de zero, sendo que a predição sobre os sinais esperados para os desse modelo foi confirmada. 
Os modelos Marginal e Jones Forward Looking apresentam desempenhos próximos com relação ao ajustamento da curva, e suas variáveis, excetuando-se a variável ' $(1+k) \Delta R_{i t}-$ $\Delta C R_{i t}$ ' no modelo Jones Forward Looking, têm coeficientes diferentes de zero. Porém, o $R^{2}$ ajustado indica que esses modelos têm menor grau de ajustamento do que o modelo KS estimado pelo MQO. Todavia, os critérios de Akaike e Schwarz indicam que o modelo Jones FL é mais bem especificado do que o KS MQO Verifica-se, também, que a variável $T A_{i t-1}$, apesar de significante, não possui o sinal esperado.

Os setores de comércio $(0,074)$ e construção $(0,128)$ no modelo KS MQO, comércio $(0,080)$, construção $(0,138)$, telecomunicações $(-0,051)$ e têxtil $(0,053)$ no modelo Marginal, e comércio $(0,033)$ e construção $(0,090)$ no modelo Jones FL, tiveram coeficientes significativos.

Tabela 60 - Estimação dos modelos operacionais no contexto norte-americano - Parte C

\begin{tabular}{|c|c|c|c|c|c|c|}
\hline & \multicolumn{2}{|c|}{ Pae } & \multicolumn{2}{|c|}{ Proposto } & \multicolumn{2}{|c|}{ Proposto (sem RM) } \\
\hline & coeficiente & p-value & coeficiente & p-value & coeficiente & p-value \\
\hline Constante & & & $-0,006$ & 0,381 & 0,001 & 0,861 \\
\hline $1 / A_{i t-1}$ & 265,016 & 0,654 & & & & \\
\hline$\Delta \mathrm{R}_{\mathrm{it}}$ & 0,031 & 0,077 & & & & \\
\hline $\mathrm{PPE}_{\text {it }}$ & -0.058 & 0,000 & & & & \\
\hline $\mathrm{FCO}_{\text {it }}$ & $-0,192$ & 0,000 & $-1,048$ & 0,000 & $-0,422$ & 0,000 \\
\hline $\mathrm{FCO}_{\text {it-1 }}$ & 0,069 & 0,004 & & & & \\
\hline $\mathrm{TA}_{\mathrm{it}-1}$ & 0,148 & 0,000 & 0,071 & 0,000 & 0,083 & 0,000 \\
\hline $\mathrm{R}_{\mathrm{it}}$ & & & 0,280 & 0,000 & 0,192 & 0,000 \\
\hline $\mathrm{CD}_{\text {it }}$ & & & $-0,247$ & 0,000 & $-0,201$ & 0,000 \\
\hline $\mathrm{AI}_{\mathrm{it}}$ & & & $-0,035$ & 0,000 & $-0,050$ & 0,007 \\
\hline $\mathrm{AD}_{\text {it }}$ & & & $-0,004$ & 0,921 & $-0,010$ & 0,811 \\
\hline $\mathrm{E}_{\mathrm{it}}$ & & & 0,261 & 0,000 & 0,219 & 0,000 \\
\hline$E_{i t}^{2}$ & & & 0,037 & 0,000 & 0,029 & 0,000 \\
\hline$\Delta \mathrm{E}_{\mathrm{t}-1}$ & & & $-0,013$ & 0,231 & $-0,025$ & 0,018 \\
\hline $\mathrm{D} \Delta \mathrm{E}_{\mathrm{it}-1}$ & & & $-0,003$ & 0,489 & -0.006 & 0,090 \\
\hline$\Delta \mathrm{E}_{\mathrm{it}-1}{ }^{*} \mathrm{D} \Delta \mathrm{E}_{\mathrm{it}-1}$ & & & $-0,014$ & 0,793 & $-0,006$ & 0,910 \\
\hline $\mathrm{Ab}$ Prod $_{\text {it }}$ & & & 0,057 & 0,000 & & \\
\hline $\mathrm{Ab} \_\mathrm{DO}_{\mathrm{it}}$ & & & 0,037 & 0,000 & & \\
\hline $\mathrm{Ab}_{-} \mathrm{CFO}_{\text {it }}$ & & & 0,612 & 0,009 & & \\
\hline$R^{2}$ & 0,130 & & 0,343 & & 0,297 & \\
\hline$R^{2}$ ajustado & 0,127 & & 0,339 & & 0,293 & \\
\hline Akaike criterion & $-1,845$ & & $-2,046$ & & $-1,991$ & \\
\hline Schwarz criterion & $-1,819$ & & $-2,002$ & & $-1,956$ & \\
\hline Estatística $F$ & & & 78,502 & 0,000 & 82,468 & 0,000 \\
\hline White Heteroskedasticity & & & & & & \\
\hline Test & 785,162 & 0,000 & 1304,910 & 0,000 & 1030,253 & 0,000 \\
\hline KB Test & 0,574 & 0,000 & 0,092 & 0,000 & 0,136 & 0,000 \\
\hline Durbin-Watson & 1,894 & & 1,773 & & 1,824 & \\
\hline Breusch-Godfrey Serial & & & & & & \\
\hline Correlation LM Test & 16,045 & 0,000 & 11,246 & 0,004 & 10,627 & 0,005 \\
\hline Jarque-Bera Test & 894725 & 0,000 & 610464 & 0,000 & 808044 & 0,000 \\
\hline Observações & 6081 & & 4840 & & 5691 & \\
\hline
\end{tabular}


O modelo Pae tem problema de heteroscedasticidade e de correlação serial nos resíduos, sendo que os coeficientes de suas variáveis explicativas são significativamente diferentes de zero, com exceção para a variável $\Delta R_{i t}$ como ocorreu na estimação do modelo Jones. Para as demais variáveis, verificou-se que as variáveis $F C O_{i t}$ e $F C O_{i t-1}$ têm sinal esperado e, assim como foi observado no modelo Jones FL, a variável $T A_{i t-1}$ tem coeficiente significativamente diferente de zero, porém o sinal não é o esperado. O setor de construção $(0,051)$ é o único que possui um coeficiente significante no modelo Pae.

Por fim, observe-se que o modelo Pae não apresenta um desempenho muito superior em relação às demais especificações para a predição dos accruals no contexto norte-americano.

O modelo proposto (com ou sem as proxies para gerenciamento das atividades operacionais) no contexto norte-americano, também apresenta problemas de heteroscedasticidade e de autocorrelação.

Conforme demonstrado na Tabela 61, quando estimado com o gerenciamento das atividades operacionais, somente os coeficientes das variáveis 'ativo diferido líquido' $\left(A D_{i t}\right)$ e o conjunto de variáveis que formam a proxy para capturar o nível de conservadorismo contábil $\left(\Delta E_{t-1}\right.$, $D \Delta E_{i t-1}$ e $\left.\Delta E_{i t-1}{ }^{*} D \Delta E_{i t-1}\right)$ não são significativamente diferentes de zero. Porém, no caso da sua estimação alternativa (sem manipulação da atividades operacionais), a variável $\Delta E_{t-1}$, passa a ser significativa, considerando-se um nível de significância de 5\%.

No contexto das companhias abertas norte-americanas, o modelo proposto apresenta um melhor poder preditivo se comparado aos modelos concorrentes, tendo um $R^{2}$ ajustado de 0,339 , enquanto na versão sem a inclusão das proxies para a manipulação das atividades reais, o grau de ajustamento é um pouco menor $\left(R^{2}\right.$ ajustado $\left.=0,293\right)$.

Tabela 61 - Comparação do ajuste dos modelos operacionais no contexto norteamericano

\begin{tabular}{l|r|r|r}
\hline \multicolumn{1}{c|}{ Modelos } & $\mathbf{R}^{2}$ ajustado & \multicolumn{1}{c}{ Akaike } & \multicolumn{1}{c}{ Schwarz } \\
\hline Setorial & 0,036 & $-1,305$ & $-1,303$ \\
Jones & 0,043 & $-1,267$ & $-1,247$ \\
KS (IV) & 0,053 & $-1,387$ & $-1,363$ \\
KS (MQO) & 0,231 & $-1,423$ & $-1,400$ \\
Marginal & 0,093 & $-1,361$ & $-1,341$ \\
Jones Forward Looking & 0,097 & $-1,742$ & $-1,713$ \\
Pae & 0,127 & $-1,845$ & $-1,819$ \\
Proposto & 0,339 & $-2,046$ & $-2,002$ \\
Proposto (sem manipulação real) & 0,293 & $-1,991$ & $-1,956$ \\
\hline
\end{tabular}

Além do modelo proposto, somente o modelo KS estimado por MQO apresentou razoável poder explicativo para comportamento dos accruals totais. Essas evidências são confirmadas 
pelos $R^{2}$ ajustado, Critério de Informação de Akaike e Critério de Informação de Schwarz, (Tabela 61), bem como pelo teste Vuong constante da Tabela 62.

Tabela 62 - Comparação do ajuste dos modelos operacionais no contexto norte-americano - Teste Vuong

\begin{tabular}{|c|c|c|c|c|c|c|c|c|}
\hline Modelo & Setorial & Jones & $\mathbf{K S}$ & $\begin{array}{c}\text { KS } \\
\text { MQO }\end{array}$ & $\begin{array}{c}\text { Margi- } \\
\text { nal }\end{array}$ & JonesFL & Pae & $\begin{array}{c}\text { Propos- } \\
\text { to }\end{array}$ \\
\hline Jones & $\begin{array}{l}-1,423 \\
\text { Indife- } \\
\text { rente }\end{array}$ & & & & & & & \\
\hline $\mathrm{KS}$ & $\begin{array}{l}1,962 \\
\mathrm{KS}\end{array}$ & $\begin{array}{l}2,198 \\
\mathrm{KS}\end{array}$ & & & & & & \\
\hline KS MQO & $\begin{array}{r}5,089 \\
\text { KS MQO }\end{array}$ & $\begin{array}{r}6,440 \\
\text { KS MQO }\end{array}$ & $\begin{array}{r}5,427 \\
\text { KS MQO }\end{array}$ & & & & & \\
\hline Marginal & $\begin{array}{r}2,725 \\
\text { Marginal }\end{array}$ & $\begin{array}{r}2,854 \\
\text { Marginal }\end{array}$ & $\begin{array}{r}2,765 \\
\text { Marginal }\end{array}$ & $\begin{array}{r}-2,461 \\
\text { KS MQO }\end{array}$ & & & & \\
\hline JonesFl & $\begin{array}{r}3,937 \\
\text { JonesFL }\end{array}$ & $\begin{array}{r}3,992 \\
\text { JonesFL }\end{array}$ & $\begin{array}{r}3,867 \\
\text { JonesFL }\end{array}$ & $\begin{array}{c}0,939 \\
\text { Indife- } \\
\text { rente }\end{array}$ & $\begin{array}{l}1,318 \\
\text { Indife- } \\
\text { rente }\end{array}$ & & & \\
\hline $\mathrm{Pae}$ & $\begin{array}{l}3,217 \\
\text { Pae }\end{array}$ & $\begin{array}{l}3,147 \\
\text { Pae }\end{array}$ & $\begin{array}{l}3,290 \\
\text { Pae }\end{array}$ & $\begin{array}{l}2,226 \\
\text { Pae }\end{array}$ & $\begin{array}{l}3,133 \\
\text { Pae }\end{array}$ & $\begin{array}{c}-2,855 \\
\text { JonesFL }\end{array}$ & & \\
\hline Proposto & $\begin{array}{r}3,260 \\
\text { Proposto }\end{array}$ & $\begin{array}{r}3,719 \\
\text { Proposto }\end{array}$ & $\begin{array}{r}3,473 \\
\text { Proposto }\end{array}$ & $\begin{array}{r}2,369 \\
\text { Proposto }\end{array}$ & $\begin{array}{r}2,891 \\
\text { Proposto }\end{array}$ & $\begin{array}{r}2,744 \\
\text { Proposto }\end{array}$ & $\begin{array}{r}2,873 \\
\text { Proposto }\end{array}$ & \\
\hline $\begin{array}{l}\text { Proposto } \\
\text { sem RM }\end{array}$ & $\begin{array}{r}4,770 \\
\text { Proposto } \\
\text { sem RM }\end{array}$ & $\begin{array}{r}2,209 \\
\text { Proposto } \\
\text { sem RM }\end{array}$ & $\begin{array}{r}2,618 \\
\text { Proposto } \\
\text { sem RM }\end{array}$ & $\begin{array}{l}1,687 \\
\text { Indife- } \\
\text { rente }\end{array}$ & $\begin{array}{r}2,401 \\
\text { Proposto } \\
\text { sem RM }\end{array}$ & $\begin{array}{r}2,788 \\
\text { Proposto } \\
\text { sem RM }\end{array}$ & $\begin{array}{r}2,851 \\
\text { Proposto } \\
\text { sem RM }\end{array}$ & $\begin{array}{r}2,042 \\
\text { Proposto } \\
\text { sem RM }\end{array}$ \\
\hline
\end{tabular}

Tabela 63 - Gerenciamento de atividades operacionais no contexto norte-americano

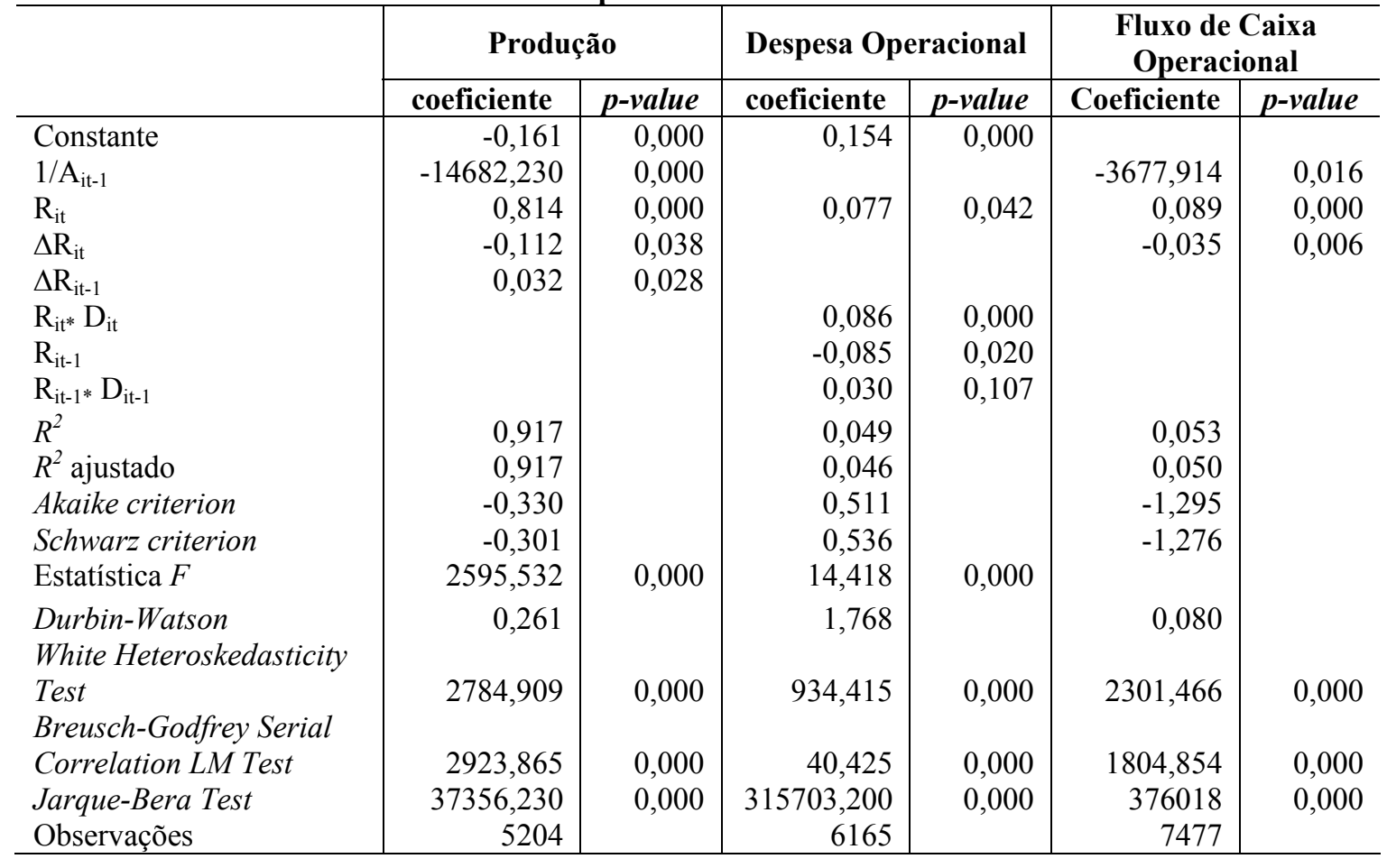


Com relação aos modelos para detecção de gerenciamento das atividades operacionais, verificou-se um grau de ajuste satisfatório somente para a análise do comportamento da produção (Tabela 63). Todos os modelos apresentam a presença de heteroscedasticidade e autocorrelação, e seus coeficientes não são significativamente iguais a zero.

Os setores de eletroeletrônicos $(0,057)$, minerais não-metálicos $(0,110)$ e softaware e dados $(0,055)$ foram significativos no modelo proposto.

\begin{tabular}{|c|c|c|}
\hline & \multicolumn{2}{|c|}{ log likelihood ratio } \\
\hline & Coeficiente & p-value \\
\hline Ab_Prod $_{\text {it }}$ & 63,957 & 0,000 \\
\hline $\mathrm{Ab} \_\mathrm{DO}_{\mathrm{it}}$ & 58,945 & 0,000 \\
\hline $\mathrm{Ab}_{-} \mathrm{CFO}_{\text {it }}$ & 71,415 & 0,000 \\
\hline $\mathrm{Ab}_{-} \operatorname{Prod}_{\mathrm{it}} \mathrm{Ab} \_\mathrm{DO}_{\mathrm{it}}$ & 111,568 & 0,000 \\
\hline $\mathrm{Ab}_{-} \operatorname{Prod}_{\mathrm{it}} \mathrm{Ab} \mathrm{CFFO}_{\mathrm{it}}$ & 134,664 & 0,000 \\
\hline $\mathrm{Ab} \_\mathrm{DO}_{\mathrm{it}} \quad \mathrm{Ab} \_\overline{\mathrm{C}} \mathrm{FO}_{\mathrm{it}}$ & 182,697 & 0,000 \\
\hline $\mathrm{Ab} \_\operatorname{Prod}_{i t} \mathrm{~A} \bar{b} \_\mathrm{DO}_{\text {it }} \quad \mathrm{Ab}_{-} \mathrm{CFO}_{\mathrm{it}}$ & 229,692 & 0,000 \\
\hline
\end{tabular}

Conforme descrito na Tabela 64, o conjunto de variáveis explicativas que são utilizadas para controlar o gerenciamento das atividades operacionais são variáveis relevantes no modelo proposto. Por outro lado, as variáveis para capturar o conservadorismo contábil não têm coeficientes significativamente diferentes de zero (Tabela 65).

Tabela 65 - Testes de variáveis redundantes para as proxies de conservadorismo - EUA

\begin{tabular}{|c|c|c|}
\hline & \multicolumn{2}{|c|}{ log likelihood ratio } \\
\hline & coeficiente & p-value \\
\hline$\Delta \mathrm{E}_{\mathrm{t}-1}$ & 2,417 & 0,120 \\
\hline $\mathrm{D} \Delta \mathrm{E}_{\mathrm{it}-1}$ & 0,749 & 0,387 \\
\hline$\Delta \mathrm{E}_{\mathrm{it}-1}^{*} \mathrm{D} \Delta \mathrm{E}_{\mathrm{it}-1}$ & 0,367 & 0,545 \\
\hline $\mathrm{D} \Delta \mathrm{E}_{\mathrm{it}-1}$ & 2,972 & 0,226 \\
\hline$\Delta \mathrm{E}_{\mathrm{it}-1}^{*} \mathrm{D} \Delta \mathrm{E}_{\mathrm{it}-1}$ & 3,886 & 0,143 \\
\hline $\mathrm{D} \Delta \mathrm{E}_{\mathrm{it}-1} \Delta \mathrm{E}_{\mathrm{it}-1}^{*} \mathrm{D} \Delta \mathrm{E}_{\mathrm{it}-1}$ & 0,911 & 0,634 \\
\hline$\Delta \mathrm{E}_{\mathrm{t}-1} \quad \mathrm{D} \Delta \mathrm{E}_{\mathrm{it}-1} \quad \Delta \mathrm{E}_{\mathrm{it}-1}{ }^{*} \mathrm{D} \Delta \mathrm{E}_{\mathrm{it}-1}$ & 4,050 & 0,256 \\
\hline
\end{tabular}

No caso de exclusão das proxies para o nível de conservadorismo, o $R^{2}$ ajustado seria de 0,339, critério de Akaike igual a -2,047 e Schwarz igual a -2,007, com resíduos heteroscedásticos e autocorrelacionados.

Os testes efetuados para analisar se existe multicolineariedade entre as variáveis explicativas dos modelos, analisados nesta pesquisa, com relação às companhias abertas norte-americanas, estão descritos na Tabela 66. Novamente, o modelo Marginal apresenta problema de multicolineariedade, por causa da alta correlação entre as suas variáveis. 
Tabela 66 - Teste de multicolineariedade Variance Inflation Factor no contexto norte-americano

\begin{tabular}{|c|c|c|c|c|c|c|c|}
\hline 00 & Jones & KS & Marginal & $\begin{array}{c}\text { Jones } \\
\text { FL }\end{array}$ & Pae & Proposto & $\begin{array}{c}\text { Proposto } \\
\text { (sem RM) }\end{array}$ \\
\hline 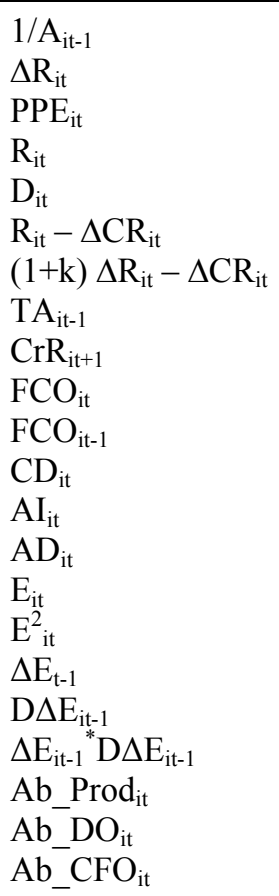 & $\begin{array}{l}1,187 \\
1,281 \\
1,124\end{array}$ & $\begin{array}{l}1,000 \\
1,189 \\
1,189\end{array}$ & $\begin{array}{l}162,396 \\
162,396\end{array}$ & $\begin{array}{l}1,031 \\
1,022 \\
1,011 \\
1,003\end{array}$ & $\begin{array}{l}1,111 \\
1,310 \\
1,591\end{array}$ & $\begin{array}{r}1,099 \\
9,212 \\
127,944 \\
1,087 \\
1,001 \\
7,188 \\
5,509 \\
2,299 \\
1,250 \\
7,420 \\
1,429 \\
1,222 \\
8,018\end{array}$ & $\begin{array}{r}1,071 \\
2,314 \\
107,234 \\
1,035 \\
1,001 \\
6,957 \\
4,439 \\
2,103 \\
1,247 \\
6,482\end{array}$ \\
\hline
\end{tabular}

As variáveis $R_{i t}$ e $C D_{\text {it }}$ possuem alta correlação e, conseqüentemente, o teste FIV indica multicolineariedade no modelo proposto envolvendo essas variáveis. Apesar de estarem em um intervalo aceitável (FIV menor que 10,000), as variáveis $\mathrm{FCO}_{\text {it }}$ e $\mathrm{Ab}_{-} \mathrm{CFO}_{\text {it }}$ mostram-se com uma certa multicolinearidade, originado da alta correlação entre elas, tanto que no modelo proposto sem as proxies de manipulação das atividades operacionais, esse pressuposto

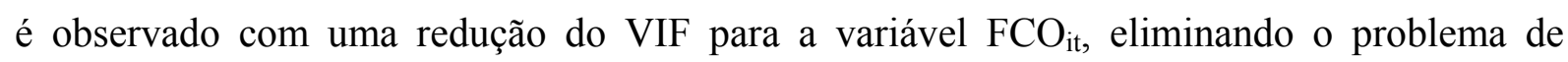
multicolineariedade.

As variáveis $R_{i t}$ e $C D_{i t}$ são relevantes para o modelo proposto conforme o teste log likelihood ratio e caso, a variável $C D_{i t}$ fosse excluída, o $R^{2}$ do modelo reduziria para 0,309 , enquanto da exclusão de $R_{i t}$, o $R^{2}$ também cairia para 0,309 .

Tabela 67 - KMO and Bartlett's Test - EUA

\begin{tabular}{|c|c|c|}
\hline \multicolumn{2}{|c|}{ Teste } & coeficiente \\
\hline \multicolumn{2}{|c|}{ Kaiser-Meyer-Olkin Measure of Sampling Adequacy. } & 0,588 \\
\hline Bartlett's Test of Sphericity & $\begin{array}{l}\text { Approx. Chi-Square } \\
\text { df } \\
\text { Sig. }\end{array}$ & $\begin{array}{r}54404,467 \\
91 \\
0,000\end{array}$ \\
\hline
\end{tabular}


Para a amostra com as companhias norte-americanas, o teste KMO foi de 0,588 , indicando que a análise fatorial não descreve, de forma adequada, as variações das variáveis originais. Pela Correlação da Matriz Anti-Imagem (Apêndice 159), também, verifica-se que existem variáveis com MSA inferior a 0,500 .

Também, foi efetuada uma segunda tentativa, eliminando as variáveis com MSA inferior a 0,500 na primeira tentativa. Com isso, o KMO elevou-se para 0,707 , sendo que agora a Correlação da Matriz Anti-Imagem (Apêndice 160) evidencia que todas as variáveis ficaram com MSA acima de 0,500. Apesar do KMO ser significativo na amostra com as empresas norte-americanas, com base nos agrupamentos formados pela análise fatorial, não se consegue identificar qualquer fator com uma característica própria.

\subsubsection{Toda a amostra}

O objetivo dessa seção é verificar se as idiossincrasias de cada país afetam o processo de mensuração dos accruals. Para tanto, formou-se uma amostra geral com todas as empresasano do Brasil, Chile, México, Peru e Estados Unidos da América. Foí criada uma variável dummy para os quatro últimos países, assim, o termo constante $(\alpha)$ dos modelos refere-se ao Brasil (país de referência), enquanto o coeficiente linear dos demais países é obtido pelo soma do termo constante $(\alpha)$ mais o coeficiente angular da variável dummy correspondente. Se o $\beta$ da variável dummy do país for significativamente diferente de zero, isso implica que as companhias abertas desse país têm um volume de accruals totais maior (se o sinal for positivo) ou menor (se o sinal for negativo) do que os das companhias abertas brasileiras.

O agrupamento dos diversos países, também, auxilia na análise dos modelos operacionais para a estimação dos accruals discricionários para a detecção do gerenciamento de resultados. O obetivo é de verificar se os resultados dessa seção corroboram as evidências encontradas nas seções anteriores.

Nas Tabelas 68 a 70, são apresentadas as estimações para os parâmetros e testes estatísticos de cada modelo através de pooling of indepedent cross section. Os resultados do teste de Jarque-Bera para todos os modelos operacionais rejeitam a hipótese nula de normalidade, assim como ocorre em cada uma das amostras isoladamente.

Em todos os modelos, os resíduos são heteroscedásticos conforme os resultados dos teste de White. Esse comportameto dos resíduos foi observado também na maioria dos modelos nas análises individuais para cada país, 
O modelo Setorial aplicado na amostra geral atende aos pressupostos de homoscedasticidade, somente pelo teste $\mathrm{KB}$, entretanto, existe evidência de presença de correlação serial dos resíduos. Observa-se um baixo poder de explicação $\left(R^{2}=0,028\right)$, mesmo considerando que pela estatística $F$, a variável independente explica o comportamento dos accruals totais.

Já no modelo Jones (1991), os resíduos são heteroscedásticos e autocorrelacionados. Porém, o modelo tem um $R^{2}$ baixo $(0,049)$. Somente o coeficiente da variável $P P E_{i t}$ é significativamente diferente de zero, que pela análise do sinal é consistente com o comportamento esperado.

Nesse modelo, observa-se que os accruals totais das companhias abertas chilenas e mexicanas são significativamente maiores dos que os accruals das brasileiras, em média, 3\% e 2,5\% sobre os seus ativos totais, respectivamente. Mas, essa evidência é fortemente prejudicada pelo baixo poder preditivo do modelo.

A estimação do modelo Jones, também, evidencia que os coeficientes das variáveis dummies para os setores de agropecuária e pesca $(0,030)$, construção $(0,069)$, energia elétrica $(0,029)$, siderurgia e metalurgia $(0,036)$, software e dados $(-0,051)$ telecomunicação $(-0,054)$ e veículos e peças $(-0,026)$ são significativamente diferentes de zero, considerando um nível de $5 \%$.

Tabela 68 - Estimação dos modelos operacionais com a amostra geral- Parte A

\begin{tabular}{l|r|r|r|r|r|r}
\hline & \multicolumn{2}{|c|}{ Setorial } & \multicolumn{2}{c|}{ Jones } & \multicolumn{2}{c}{ KS } \\
\cline { 2 - 7 } & coeficiente & $\boldsymbol{p}$-value & coeficiente & p-value & coeficiente & p-value \\
\hline Constante & 0,032 & 0,004 & & & $-0,047$ & 0,000 \\
Mediana TA $_{1 / \mathrm{A}_{\mathrm{it}-1}}$ & 1,401 & 0,000 & & & & \\
$\Delta \mathrm{R}_{\mathrm{it}}$ & & & 1,490 & 0,324 & & \\
$\mathrm{PPE}_{\mathrm{it}}$ & & & 0,041 & 0,408 & & \\
$\mathrm{R}_{\mathrm{it}}$ & & & $-0,062$ & 0,000 & $-0,001$ & 0,211 \\
$\mathrm{D}_{\mathrm{it}}$ & & & & & 0,001 & 0,000 \\
Chile & 0,021 & 0,000 & 0,030 & 0,000 & $-0,001$ & 0,000 \\
México & 0,010 & 0,092 & 0,025 & 0,000 & 0,012 & 0,001 \\
Peru & 0,017 & 0,094 & 0,018 & 0,062 & 0,034 & 0,007 \\
EUA & 0,008 & 0,060 & 0,002 & 0,567 & 0,008 & 0,049 \\
$R^{2}$ & 0,028 & & 0,049 & & 0,037 & \\
$R^{2}$ ajustado & 0,027 & & 0,047 & & 0,035 & \\
Akaike criterion & $-0,723$ & & $-0,722$ & & $-0,959$ & \\
Schwarz criterion & $-0,715$ & & $-0,704$ & & $-0,937$ & \\
Estatística F & 29,880 & 0,000 & & & 13,680 & 0,000 \\
White Heteroskedasticity & & & & & & \\
Test & 240,579 & 0,000 & 5833,305 & 0,000 & 2519,173 & 0,000 \\
KB Test & 1,274 & 0,204 & 5,679 & 0,000 & 0,294 & 0,586 \\
Durbin-Watson & 1,676 & & 1,691 & & 1,735 & \\
Breusch-Godfrey Serial & 149,132 & 0,000 & & & & \\
Correlation LM Test & & & 135,163 & 0,000 & 141,114 & 0,000 \\
Jarque-Bera Test & 19135867 & 0,000 & 19219435 & 0,000 & 5641585 & 0,000 \\
Observaçõesr & 14492 & & 13989 & & 11975 & \\
\hline
\end{tabular}


O modelo KS estimado por meio do método de variáveis instrumentais (IV) também apresenta heteroscedasticidade (somente pelo teste de White), autocorrelação e baixo grau de ajustamento. As estimativas das variáveis apresentam o sinal esperado, mas a variável $P P E_{t}$ não é significativa para a predição dos accruals. Nesse modelo, as variáveis dummies para os setores de agropecuária e pesca $(0,031)$, construção $(0,069)$, energia elétrica $(0,030)$, siderurgia e metalurgia $(0,036)$, software e dados $(-0,051)$, telecomunicação $(-0,053)$ e veículos e peças $(-0,026)$ têm coeficientes significativamente diferentes de zero. Com relação os coeficientes dos países, do Chile e do Peru, são significativamente diferentes de zero.

Os parâmetros do modelo KS pelo método dos Mínimos Quadrados Ordinários mostram-se com os mesmos problemas do modelo estimado por IV. Conforme demonstrado na Tabela 65, o modelo KS com a amostra total evidencia que os coeficientes das variáveis $R_{i t}$ e $D_{i t}$ são diferentes de zero $(\beta \neq 0)$, enquanto o da variável $P P E_{i t}$ é igual a zero, diferentemente do que ocorreu no modelo estimado pelo método IV. O $R^{2}$ do modelo melhora, mas, continua baixo $(0,048)$. O modelo KS pelo MQO tem os mesmos coeficientes significantes para os setores econômicos, mas nessa estimação, o México é significativamente diferente de zero, no lugar do Peru.

Tabela 69 - Estimação dos modelos operacionais com a amostra geral - Parte B

\begin{tabular}{|c|c|c|c|c|c|c|}
\hline & \multicolumn{2}{|c|}{ KS MQO } & \multicolumn{2}{|c|}{ Marginal } & \multicolumn{2}{|c|}{ Jones FL } \\
\hline & coeficiente & p-value & coeficiente & p-value & coeficiente & p-value \\
\hline Constante & $-0,011$ & 0,637 & $-0,049$ & 0,0000 & $-0,008$ & 0,392 \\
\hline $\mathrm{R}_{\mathrm{it}}$ & 0,050 & 0,258 & 0,455 & 0,0000 & & \\
\hline $\mathrm{D}_{\text {it }}$ & $-0,040$ & 0,393 & & & & \\
\hline $\mathrm{PPE}_{\text {it }}$ & $-0,051$ & 0,045 & & & & \\
\hline $\mathrm{R}_{\mathrm{it}}-\Delta \mathrm{CR}_{\mathrm{it}}$ & & & $-0,469$ & 0,000 & & \\
\hline$(1+\mathrm{k}) \Delta \mathrm{R}_{\mathrm{it}}-\Delta \mathrm{CR}_{\mathrm{it}}$ & & & & & 0,027 & 0,065 \\
\hline $\mathrm{TA}_{\mathrm{it}-1}$ & & & & & $-0,062$ & 0,000 \\
\hline $\mathrm{CrR}_{\mathrm{it}+1}$ & & & & & 0,094 & 0,005 \\
\hline Chile & 0,028 & 0,000 & 0,030 & 0,0000 & $1,88 \mathrm{E}-05$ & 0,100 \\
\hline México & 0,021 & 0,001 & 0,021 & 0,0006 & 0,021 & 0,001 \\
\hline Peru & 0,017 & 0,121 & 0,035 & 0,0040 & 0,019 & 0,002 \\
\hline EUA & $-0,000$ & 0,943 & 0,013 & 0,0010 & 0,021 & 0,118 \\
\hline$R^{2}$ & 0,048 & & 0,081 & & 0,065 & \\
\hline$R^{2}$ ajustado & 0,045 & & 0,079 & & 0,062 & \\
\hline Akaike criterion & $-0,684$ & & $-0,924$ & & $-1,103$ & \\
\hline Schwarz criterion & $-0,664$ & & $-0,905$ & & $-1,078$ & \\
\hline Estatística $F$ & 19,709 & 0,000 & 35,978 & 0,000 & 20,669 & 0,000 \\
\hline White Heteroskedasticity & & & & & & \\
\hline Test & 8805,526 & 0,000 & 2429,055 & 0,000 & 1663,239 & 0,000 \\
\hline KB Test & 4,719 & 0,000 & 0,745 & 0,000 & 0,606 & 0,001 \\
\hline Durbin-Watson & 1,673 & & 1,672 & & 2,028 & \\
\hline Breusch-Godfrey Serial & & & & & & \\
\hline Correlation LM Test & 123,613 & 0,000 & 222,345 & 0,000 & 16,195 & 0,000 \\
\hline Jarque-Bera Test & 16855945 & 0,000 & 10001839 & 0,000 & 4323003 & 0,000 \\
\hline Observações & 13500 & & 13548 & & 10068 & \\
\hline
\end{tabular}


No modelo Marginal, os $\beta$ 's dos parâmetros originais e para as dummies dos países são significativamente diferentes de zero, aumentando o grau de ajustamento $\left(R^{2}=0,081\right)$, mas com resíduos heteroscedásticos e autocorrelacionados. Para o modelo Marginal, as variáveis dummies dos setores econômicos que têm coeficientes significativos são agropecuária e pesca $(0,023)$, comércio $(0,042)$, construção $(0,098)$, siderurgia e metalurgia $(0,030)$, software e dados $(-0,49)$ e telecomunicação $(-0,067)$.

Assim como o modelo Jones, o modelo Jones Forward Looking apresenta os mesmos problemas de heteroscedasticidade e autocorrelação. Somente o $\beta$ da variável 'diferença ajustada entre a variação das receitas e a variação das contas a receber' é estatisticamente igual a zero, com um aumento do poder preditivo $\left(R^{2}=0,065\right)$ em relação ao modelo predecessor. O México e Peru têm coeficientes diferentes de zero, enquanto somente os $\beta$ 's dos setores construção $(0,053)$ e telecomunicação $(-0,042)$ têm coeficientes significativos.

O modelo proposto por Pae (2005) apresenta um maior grau de ajustamento $\left(R^{2}=0,127\right)$ do que os modelos anteriores e seus resíduos são heteroscedásticos, mas não são autocorrelacionados. As estimativas das variáveis 'variação da receita líquida' $\left(\Delta R_{i t-1}\right)$ e 'fluxo de caixa operacional defasado’ $\left(F C O_{i t-1}\right)$ não são significativamente diferentes de zero.

A inclusão da variável 'accruals totais defasados' $\left(T A_{i t-1}\right)$, que representa a reversão natural dos accruals, apresenta sinal positivo, diferente do que é esperado para essa variável na predição dos accruals.

Para o modelo Pae, os coeficientes para o Chile $(0,027)$ e México $(0,022)$ são significativos, enquanto a análise dos coeficientes dos setores econômicos indica que os setores de construção (0,041), energia elétrica $(0,029)$, siderurgia e metalurgia $(0,037)$ e telecomunicações $(-0,043)$ têm estimativas significativas.

$\mathrm{Na}$ especificação do modelo proposto com as proxies de gerenciamento das atividades operacionais, os coeficientes das variáveis 'ativo diferido' $\left(A D_{i t}\right)$, a variável de interação para o nível de conservadorismo $\left(\Delta E_{i t-1}{ }^{*} D \Delta E_{i t-1}\right)$ e as proxies de gerenciamentos das atividades operacionais não são significativas. Todos as variáveis, exceto a dos 'accruals totais defasados' $\left(T A_{i t-1}\right)$, têm sinais como preditos na seção 3.6.2.

Com relação a análise entre os países, os coeficientes do Peru $(-0,054)$ e Estados Unidos da América $(-0,025)$ têm $\beta$ 's diferentes de zero, enquanto, somente o coeficiente da dummy para o setor siderurgia e metalurgia $(0,030)$, é significativamente diferente de zero. 
Tabela 70 - Estimação dos modelos operacionais com a amostra geral - Parte C

\begin{tabular}{|c|c|c|c|c|c|c|}
\hline & \multicolumn{2}{|c|}{ Pae } & \multicolumn{2}{|c|}{ Proposto } & \multicolumn{2}{|c|}{ Proposto (sem RM) } \\
\hline & coeficiente & p-value & coeficiente & p-value & coeficiente & p-value \\
\hline Constante & & & 0,066 & 0,011 & 0,011 & 0,592 \\
\hline $1 / A_{\text {it- } 1}$ & $-2,816$ & 0,176 & & & & \\
\hline$\Delta \mathrm{R}_{\mathrm{it}}$ & 0,072 & 0,069 & & & & \\
\hline $\mathrm{PPE}_{\mathrm{it}}$ & $-0,056$ & 0,001 & & & & \\
\hline $\mathrm{FCO}_{\text {it }}$ & $-0,173$ & 0,011 & $-0,873$ & 0,044 & $-0,369$ & 0,000 \\
\hline $\mathrm{FCO}_{\text {it-1 }}$ & 0,079 & 0,073 & & & & \\
\hline $\mathrm{TA}_{\mathrm{it}-1}$ & 0,127 & 0,000 & 0,047 & 0,042 & 0,066 & 0,008 \\
\hline $\mathrm{R}_{\mathrm{it}}$ & & & 0,309 & 0,000 & 0,329 & 0,000 \\
\hline $\mathrm{CD}_{\text {it }}$ & & & $-0,310$ & 0,000 & $-0,329$ & 0,000 \\
\hline $\mathrm{AI}_{\mathrm{it}}$ & & & $-0,040$ & 0,006 & $-0,032$ & 0,026 \\
\hline $\mathrm{AD}_{\text {it }}$ & & & $-0,759$ & 0,337 & $-0,497$ & 0,562 \\
\hline $\mathrm{E}_{\mathrm{it}}$ & & & 0,285 & 0,000 & 0,117 & 0,035 \\
\hline $\mathrm{E}^{2}{ }_{\mathrm{it}}$ & & & 0,037 & 0,000 & 0,009 & 0,004 \\
\hline$\Delta \mathrm{E}_{\mathrm{t}-1}$ & & & $-0,067$ & 0,000 & $-0,020$ & 0,010 \\
\hline $\mathrm{D} \Delta \mathrm{E}_{\mathrm{it}-1}$ & & & $-0,019$ & 0,001 & $-0,016$ & 0,000 \\
\hline$\Delta \mathrm{E}_{\mathrm{it}-1}^{*} \mathrm{D} \Delta \mathrm{E}_{\mathrm{it}-1}$ & & & $-0,039$ & 0,681 & $-0,065$ & 0,059 \\
\hline Ab_Prod ${ }_{i t}$ & & & 0,075 & 0,105 & & \\
\hline $\mathrm{Ab} \_\mathrm{DO}_{\mathrm{it}}$ & & & 0,008 & 0,362 & & \\
\hline $\mathrm{Ab}_{-} \mathrm{CFO}_{\text {it }}$ & & & 0,366 & 0,401 & & \\
\hline Chile & 0,027 & 0,000 & $-0,013$ & 0,186 & 0,008 & 0,241 \\
\hline México & 0,022 & 0,000 & 0,014 & 0,340 & 0,009 & 0,096 \\
\hline Peru & 0,008 & 0,363 & $-0,054$ & 0,015 & $-0,013$ & 0,124 \\
\hline EUA & 0,005 & 0,180 & $-0,025$ & 0,003 & $-0,014$ & 0,001 \\
\hline$R^{2}$ & 0,127 & & 0,301 & & 0,252 & \\
\hline$R^{2}$ ajustado & 0,125 & & 0,298 & & 0,250 & \\
\hline Akaike criterion & $-0,931$ & & $-1,216$ & & $-1,077$ & \\
\hline Schwarz criterion & $-0,909$ & & $-1,185$ & & $-1,051$ & \\
\hline Estatística $F$ & & & 101,395 & 0,000 & 98,678 & 0,000 \\
\hline White Heteroskedasticity & & & & & & \\
\hline Test & 8161,614 & 0,000 & 3252,860 & 0,000 & 4624,633 & 0,000 \\
\hline KB Test & 1,855 & 0,000 & 0,928 & 0,000 & 0,697 & 0,000 \\
\hline Durbin-Watson & 1,899 & & 1,839 & & 1,793 & \\
\hline Breusch-Godfrey Serial & & & & & & \\
\hline Correlation LM Test & 4,987 & 0,083 & 83,397 & 0,000 & 45,322 & 0,000 \\
\hline Jarque-Bera Test & 12036113 & 0,000 & 7969433 & 0,000 & 10873004 & 0,000 \\
\hline Observações & 12294 & & 10422 & & 12046 & \\
\hline
\end{tabular}

Esse modelo tem um acréscimo no grau de ajustamento em relação aos modelos concorrentes, passando a indicar um $R^{2}$ de 0,301 , o que demonstra que ele tem maior poder preditivo do que os demais modelos na estimação do comportamento dos accruals totais.

Estimando o modelo proposto sem a inclusão das variáveis para controlar a manipulação das atividades reais, observou-se que o grau de ajustamento do modelo teve uma redução, pois o $R^{2}$ ajustado passou de 0,298 para 0,250, sendo que somente a variável para o EUA é significativa entre as dummies criadas para controlar as características de cada país. 
Tabela 71 - Gerenciamento de atividades operacionais - Amostra Geral

\begin{tabular}{|c|c|c|c|c|c|c|}
\hline & \multicolumn{2}{|c|}{ Produção } & \multicolumn{2}{|c|}{ Despesa Operacional } & \multicolumn{2}{|c|}{$\begin{array}{l}\text { Fluxo de Caixa } \\
\text { Operacional }\end{array}$} \\
\hline & coeficiente & p-value & coeficiente & p-value & coeficiente & p-value \\
\hline Constante & $-0,091$ & 0,000 & 0,125 & 0,000 & & \\
\hline $1 / \mathrm{A}_{\mathrm{it}-1}$ & 0,249 & 0,000 & & & $-31,573$ & 0,000 \\
\hline $\mathrm{R}_{\mathrm{it}}$ & 0,821 & 0,000 & 0,168 & 0,000 & 0,038 & 0,000 \\
\hline$\Delta \mathrm{R}_{\mathrm{it}}$ & $-0,105$ & 0,054 & & & $-0,054$ & 0,197 \\
\hline$\Delta \mathrm{R}_{\mathrm{it}-1}$ & 0,010 & 0,566 & & & & \\
\hline $\mathrm{R}_{\mathrm{it}} \mathrm{D}_{\mathrm{it}}$ & & & 0,064 & 0,000 & & \\
\hline $\mathrm{R}_{\mathrm{it}-1}$ & & & $-0,166$ & 0,000 & & \\
\hline $\mathrm{R}_{\mathrm{it}-1} * \mathrm{D}_{\mathrm{it}-1}$ & & & 0,046 & 0,000 & & \\
\hline Chile & 0,025 & 0,000 & $-0,008$ & 0,475 & $-0,020$ & 0,009 \\
\hline México & $-0,045$ & 0,000 & 0,036 & 0,001 & 0,030 & 0,000 \\
\hline Peru & 0,036 & 0,073 & $-0,006$ & 0,687 & $-0,053$ & 0,001 \\
\hline EUA & $-0,084$ & 0,000 & 0,047 & 0,000 & 0,010 & 0,065 \\
\hline$R^{2}$ & 0,832 & & 0,126 & & 0,317 & \\
\hline$R^{2}$ ajustado & 0,831 & & 0,124 & & 0,315 & \\
\hline Akaike criterion & 0,311 & & 0,508 & & $-0,015$ & \\
\hline Schwarz criterion & 0,333 & & 0,529 & & 0,003 & \\
\hline Estatística $F$ & 1700,610 & 0,000 & 50,890 & 0,000 & & \\
\hline White Heteroskedasticity & & & & & & \\
\hline Test & 9692,949 & 0,000 & 2497,028 & 0,000 & 8332,022 & 0,000 \\
\hline Durbin-Watson & 0,361 & & 1,823 & & 1,017 & \\
\hline Breusch-Godfrey Serial & & & & & & \\
\hline Correlation LM Test & 7224,070 & 0,000 & 43,372 & 0,000 & 3112,346 & 0,000 \\
\hline Jarque-Bera Test & $1,78 \mathrm{E}+08$ & 0,000 & 318486 & 0,000 & $1,24 \mathrm{E}+09$ & 0,000 \\
\hline Observações & 12034 & & 12037 & & 14449 & \\
\hline
\end{tabular}

Na Tabela 71, são apresentadas as estimações dos parâmetros e dos testes estatísticos para as proxies de gerenciamento das atividades operacionais utilizadas no modelo proposto. Como evidenciado anteriormente nas amostras analisadas isoladamente, o modelo para avaliar o comportamento dos custos de produção tem um elevado grau de ajustamento $\left(R^{2}=0,832\right)$, o que nem sempre é observado nos modelos de despesa operacional $\left(R^{2}=0,126\right)$ e do fluxo de caixa operacional $\left(R^{2}=0,317\right)$. Observa-se, também, que todas as regressões têm presença de heteroscedasticidade e de autocorrelação.

Os testes Variance Inflation Factor para todos os modelos de estimação dos accruals para a amostra geral são descritos na Tabela 72. Como verificado anteriormente em cada ambiente econômico, somente os modelos Marginal e o Proposto possuem problemas de multicolineariedade na especificação. $\mathrm{O}$ modelo proposto apresenta multicolinearidade nas variáveis $R_{i t}, F C O_{i t}, C D_{i t}$ e $A b_{-} C F O_{i t}$. 
Tabela 72 - Teste de multicolineariedade Variance Inflation Factor - Amostra Geral

\begin{tabular}{|c|c|c|c|c|c|c|c|}
\hline & Jones & KS & Marginal & $\begin{array}{c}\text { Jones } \\
\text { FL }\end{array}$ & Pae & Proposto & $\begin{array}{r}\text { Proposto } \\
\text { (sem RM) }\end{array}$ \\
\hline $1 / A_{i t-1}$ & 1,000 & & & & 1,472 & & \\
\hline$\Delta \mathrm{R}_{\mathrm{it}}$ & 1,157 & & & & 1,182 & & \\
\hline $\mathrm{PPE}_{i \mathrm{it}}$ & 2,014 & 1,000 & & 1,140 & 2,139 & & \\
\hline $\mathrm{R}_{\mathrm{it}}$ & & 1,189 & 111,409 & & & 59,219 & 44,573 \\
\hline & & 1,190 & & & & & \\
\hline $\begin{array}{l}R_{\text {it }}-\Delta \mathrm{CR}_{\text {it }} \\
(1+\mathrm{k}) \Delta \mathrm{R}_{\mathrm{it}}-\Delta \mathrm{CR}_{\mathrm{it}}\end{array}$ & & & 111,417 & 1047 & & & \\
\hline $\mathrm{TA}_{\mathrm{it}-1}$ & & & & 1,013 & 1,109 & 1,079 & 1,049 \\
\hline $\mathrm{CrR}_{\mathrm{it}+1}$ & & & & 1,001 & & & \\
\hline $\mathrm{FCO}_{i t}$ & & & & & 2,346 & 208,156 & 2,557 \\
\hline $\mathrm{FCO}_{\text {it-1 }}$ & & & & & 1,856 & & \\
\hline $\mathrm{CD}_{\mathrm{it}}$ & & & & & & 58,710 & 45,459 \\
\hline $\mathrm{AI}_{\mathrm{it}}$ & & & & & & 1,243 & 1,121 \\
\hline $\mathrm{AD}_{\text {it }}$ & & & & & & 1,131 & 1,098 \\
\hline $\mathrm{E}_{\mathrm{it}}$ & & & & & & 4,440 & 5,452 \\
\hline$E_{i t}^{2}$ & & & & & & 3,979 & 3,724 \\
\hline$\Delta \mathrm{E}_{\mathrm{t}-1}$ & & & & & & 2,790 & 1,614 \\
\hline $\mathrm{D} \Delta \mathrm{E}_{\mathrm{it}-1}$ & & & & & & 1,168 & 1,090 \\
\hline$\Delta \mathrm{E}_{\mathrm{it}-1}{ }^{*} \mathrm{D} \Delta \mathrm{E}_{\mathrm{it}-1}$ & & & & & & 3,021 & 1,836 \\
\hline Ab_Prod ${ }_{i t}$ & & & & & & 1,190 & \\
\hline $\mathrm{Ab} \mathrm{bO}_{\mathrm{it}}$ & & & & & & 1,229 & \\
\hline $\mathrm{Ab} \mathrm{CFO}_{\mathrm{it}}$ & & & & & & 208,400 & \\
\hline Chile & 1,220 & 1,356 & 1,374 & 1,395 & 1,194 & 1,000 & 1,000 \\
\hline México & 1,188 & 1,288 & 1,292 & 1,324 & 1,222 & 1,464 & 1,328 \\
\hline Peru & 1,107 & 1,018 & 1,017 & 1,017 & 1,118 & 1,001 & 1,000 \\
\hline EUA & 1,377 & 1,537 & 1,558 & 1,617 & 1,443 & 1,460 & 1,369 \\
\hline
\end{tabular}

Buscando reduzir o número de variáveis necessárias para descrever os comportamento dos accruals, efetuou-se a análise fatorial exploratória com o intuito de identificar fatores e solucionar problemas de multicolineariedade. Porém, conforme apresentado na Tabela 69, a utilização dessa técnica também não é satisfatória na amostra com todos os paíes, porque o teste de KMO é igual a 0,457 , indicando que fatores encontrados pela análise fatorial não descrevem adequadamente as variações das variáveis originais.

Analisando a Correlação da Matriz Anti-Imagem (Apêndice 162), verifica-se que a maioria das variáveis tem MSA inferior a 0,50, sendo que esses indicadores são considerados muito baixos e, assim essas variáveis devem ser retiradas da Análise Fatorial, o que impossibilita a utilização dessa técnica. Portanto, a Análise Fatorial, no contexto geral, não é adequada para criar fatores que expliquem o comportamento dos accruals.

Tabela 73 - KMO and Bartlett's Test - Amostra Geral

\begin{tabular}{llr}
\hline \multicolumn{2}{c}{ Teste } & \multicolumn{1}{c}{ coeficiente } \\
\hline Kaiser-Meyer-Olkin Measure of Sampling Adequacy. & 0,457 \\
Bartlett's Test of Sphericity & Approx. Chi-Square & 99501,148 \\
& Df & 91 \\
& Sig. & 0,000 \\
\hline
\end{tabular}


Continuando na análise sobre o poder explicativo dos modelos, o modelo proposto apresenta o melhor ajustamento para avaliação do comportamento dos accruals entre os modelos concorrentes, seguido do modelo proposto sem as proxies do gerenciamento de atividades operacionais.

Tabela 74 - Comparação do ajuste dos modelos operacionais - Amostra Geral

\begin{tabular}{l|r|r|r}
\hline \multicolumn{1}{c|}{ Modelos } & $\mathbf{R}^{2}$ ajustado & Akaike & Schwarz \\
\hline Setorial & 0,027 & $-0,723$ & $-0,715$ \\
Jones & 0,047 & $-0,722$ & $-0,704$ \\
KS & 0,035 & $-0,959$ & $-0,937$ \\
KS MQO & 0,045 & $-0,684$ & $-0,664$ \\
Marginal & 0,079 & $-0,924$ & $-0,905$ \\
Jones FL & 0,062 & $-1,103$ & $-1,078$ \\
Pae & 0,125 & $-0,931$ & $-0,909$ \\
Proposto & 0,298 & $-1,216$ & $-1,185$ \\
Proposto (sem RM) & 0,250 & $-1,077$ & $-1,051$ \\
\hline
\end{tabular}

Considerando somente o Critério de Schwarz, o modelo Jones Forward Looking $(-1,078)$ tem um grau de ajustamento mais próximo do modelo proposto $(-1,185)$ e é, inclusive, melhor do que o modelo proposto sem as proxies de gerenciamento das atividades operacionais $(-1,051)$. Tanto pelo $R^{2}$ ajustado, quanto pelo teste Vuong, o modelos KS apresentou maior poder preditivo quando estimado pelo método MQO.

Tabela 75 - Comparação dos modelos operacionais na Amostra Geral - Teste Vuong

\begin{tabular}{|c|c|c|c|c|c|c|c|c|}
\hline Modelo & Setorial & Jones & KS & $\begin{array}{c}\text { KS } \\
\text { MQO }\end{array}$ & $\begin{array}{c}\text { Margi- } \\
\text { nal }\end{array}$ & $\begin{array}{c}\text { Jones } \\
\text { FL } \\
\end{array}$ & Pae & $\begin{array}{c}\text { Propos- } \\
\text { to }\end{array}$ \\
\hline Jones & $\begin{array}{l}28,516 \\
\text { Jones }\end{array}$ & & & & & & & \\
\hline $\mathrm{KS}$ & $\begin{array}{c}-67,212 \\
\text { Setorial }\end{array}$ & $\begin{array}{l}-72,398 \\
\text { Jones }\end{array}$ & & & & & & \\
\hline KS MQO & $\begin{array}{l}-14,045 \\
\text { Setorial }\end{array}$ & $\begin{array}{l}-58,240 \\
\text { Jones }\end{array}$ & $\begin{array}{c}63,601 \\
\mathrm{KS} \\
\mathrm{MQO}\end{array}$ & & & & & \\
\hline Marginal & $\begin{array}{r}70,229 \\
\text { Marginal } \\
\end{array}$ & $\begin{array}{r}49,671 \\
\text { Marginal } \\
\end{array}$ & $\begin{array}{r}85,853 \\
\text { Marginal }\end{array}$ & $\begin{array}{r}69,655 \\
\text { Marginal } \\
\end{array}$ & & & & \\
\hline JonesFl & $\begin{array}{c}93,029 \\
\text { JonesFl } \\
\end{array}$ & $\begin{array}{c}90,974 \\
\text { JonesFl }\end{array}$ & $\begin{array}{l}111,511 \\
\text { JonesFl }\end{array}$ & $\begin{array}{r}96,105 \\
\text { JonesFl }\end{array}$ & $\begin{array}{c}67,862 \\
\text { JonesFl } \\
\end{array}$ & & & \\
\hline $\mathrm{Pae}$ & $\begin{array}{l}62,098 \\
\mathrm{Pae}\end{array}$ & $\begin{array}{l}43,657 \\
\text { Pae }\end{array}$ & $\begin{array}{l}98,764 \\
\text { Pae }\end{array}$ & $\begin{array}{l}54,880 \\
\text { Pae }\end{array}$ & $\begin{array}{l}54,873 \\
\text { Pae }\end{array}$ & $\begin{array}{l}31,835 \\
\mathrm{Pae}\end{array}$ & & \\
\hline Proposto & $\begin{array}{r}71,154 \\
\text { Proposto }\end{array}$ & $\begin{array}{r}68,786 \\
\text { Proposto } \\
\end{array}$ & $\begin{array}{r}85,535 \\
\text { Proposto } \\
\end{array}$ & $\begin{array}{r}72,687 \\
\text { Proposto } \\
\end{array}$ & $\begin{array}{r}63,175 \\
\text { Proposto } \\
\end{array}$ & $\begin{array}{r}40,371 \\
\text { Proposto } \\
\end{array}$ & $\begin{array}{r}32,987 \\
\text { Proposto } \\
\end{array}$ & \\
\hline $\begin{array}{l}\text { Proposto } \\
\text { sem RM }\end{array}$ & $\begin{array}{r}82,266 \\
\text { Proposto } \\
\text { sem RM } \\
\end{array}$ & $\begin{array}{r}79,472 \\
\text { Proposto } \\
\text { sem RM } \\
\end{array}$ & $\begin{array}{r}108,577 \\
\text { Proposto } \\
\text { sem RM } \\
\end{array}$ & $\begin{array}{r}85,194 \\
\text { Proposto } \\
\text { sem RM } \\
\end{array}$ & $\begin{array}{r}67,737 \\
\text { Proposto } \\
\text { sem RM } \\
\end{array}$ & $\begin{array}{r}39,578 \\
\text { Proposto } \\
\text { sem RM } \\
\end{array}$ & $\begin{array}{r}33,444 \\
\text { Proposto } \\
\text { sem RM } \\
\end{array}$ & $\begin{array}{r}-37,540 \\
\text { Proposto }\end{array}$ \\
\hline
\end{tabular}


Por fim, com base nas Tabelas 74 e 75 o modelo proposto neste trabalho tem a melhor especificação para predição do comportamento dos accruals com a amostra geral. Observa-se, também, que o modelo especificado com as proxies de gerenciamento de resultados através das atividades operacionais tem maior poder preditivo do que o modelo sem a presença dessas variáveis.

Para verificar a efetiva contribuição das proxies de gerenciamento das atividades operacionais no modelo proposto, foi efetuado teste log likelihood ratio para amostra total (Tabela 72). Verificou-se que a variável $A b_{-} \operatorname{Prod}_{i t}$ é irrelevante, podendo ser extraída do modelo originalmente descrito, sem prejuízo para o $R^{2}$ ajustado e os critérios de Akaike Schwarz.

Mas, apesar da relevância por este teste das variáveis $A b_{-} D O_{i t}$ e $A b_{-} C F O_{i t}$, os testes t indicam que seus coeficientes não são significativamene diferentes de zero na amostra geral. Caso essas variáveis fossem extraídas, o $R^{2}$ ajustado cairia para 0,237 .

Tabela 76 - Testes de variáveis redundantes para as proxies de gerenciamento de atividades operacionais - Amosta Geral

\begin{tabular}{|c|c|c|}
\hline & \multicolumn{2}{|c|}{ log likelihood ratio } \\
\hline & coeficiente & p-value \\
\hline Ab_Prod ${ }_{i t}$ & 2,258 & 0,134 \\
\hline $\mathrm{Ab} \_\mathrm{DO}_{i t}$ & 46,737 & 0,000 \\
\hline $\mathrm{Ab}_{-} \mathrm{CFO}_{\text {it }}$ & 36,553 & 0,000 \\
\hline $\mathrm{Ab} \_\operatorname{Prod}_{\mathrm{it}}$ Ab_DO $\mathrm{DO}_{\mathrm{it}}$ & 47,853 & 0,000 \\
\hline $\mathrm{Ab}_{-} \operatorname{Prod}_{\mathrm{it}} \mathrm{Ab} \mathrm{C}_{-} \mathrm{CFO}_{\mathrm{it}}$ & 37,997 & 0,000 \\
\hline $\mathrm{Ab}_{-} \mathrm{DO}_{\mathrm{it}} \mathrm{Ab} \mathrm{C}_{-} \mathrm{C} F \mathrm{O}_{\mathrm{it}}$ & 102,173 & 0,000 \\
\hline $\mathrm{Ab}_{-} \operatorname{Prod}_{\mathrm{it}} \mathrm{A} \overline{\mathrm{b}} \_\mathrm{DO}_{\mathrm{it}} \quad \mathrm{Ab} \_\mathrm{CFO}_{\mathrm{it}}$ & 102,515 & 0,000 \\
\hline
\end{tabular}

Para analisar a contribuição da proxy do nível de conservadorismo, foram efetuados os testes (isolados e conjuntos) de variáveis redundantes para variáveis $\Delta E_{t-1}, D \Delta E_{i t-1}$ e $\Delta E_{i t-1}{ }^{*} D \Delta E_{i t-1}$, apresentados na Tabela 77, sendo que as evidências apresentadas não comprovam a relevância dessas variáveis isoladas. Porém, o conjunto dessas variáveis é relevante e pode ser considerado como relevante para o modelo proposto na predição do comportamento dos accruals.

\begin{tabular}{l|r|r} 
Tabela 77 - Testes de variáveis redundantes para as proxies de \\
conservadorismo - Amostra Geral
\end{tabular}


Também foram testadas as variáveis com problemas de multicolinearidade no modelo proposto. Com base nos testes de variáveis redundantes (log likelihood ratio), verificou-se que as variáveis $R_{i t}, C D_{i t} F C O_{i t}$ e $A b_{-} C F O_{i t}$ são relevantes.

\subsection{Análise das suposições e ajustes do modelo proposto}

Com base nas evidências apresentadas na seção 5.2, o modelo proposto teve melhor poder explicativo do comportamento dos accruals do que as alternativas concorrentes nos países analisados neste trabalho. Conseqüentemente, ele também identifica de forma mais adequada o componente discricionário que é utilizado no modelo geral para a detecção do gerenciamento de resultados através das escolhas contábeis.

Porém, o poder preditivo do modelo proposto em cada país não tem se apresentado constante nesta pesquisa, sendo que essa oscilação também é verificada para os demais modelos.

Portanto, torna-se oportuno realizar uma análise das suposições assumidas e quando couber efetuar ajustes no modelo originalmente proposto, com o propósito de aperfeiçoar a especificação, de forma a refletir mais adequadamente a realidade econômica.

Com o intuito de analisar os testes e os graus de ajustes, a Tabela 78 apresenta comparativamente, as estimativas dos parâmetros e testes para o modelo proposto nos vários países analisados neste estudo. Com relação aos pressupostos da regressão linear múltipla, foi observado que:

a) Linearidade: como discutido anteriormente, todos os modelos operacionais apresentados atendem ao pressuposto da linearidade, pois, na sua formulação algébrica, são lineares nos parâmetros (GREENE, 2003, p.10-13);

b) Exogeneidade: como observado anteriormente, os regressores do modelo não têm forte correlação com os resíduos, portanto, as variáveis explicativas não carregam informações sobre os resíduos do modelo proposto;

c) Normalidade: os resíduos do modelo proposto não seguem uma distribuição normal, conforme o teste Jarque-Bera efetuado;

d) Homoscedasticidade: em todos os ambientes econômicos, o modelo apresenta heteroscedasticidade, conforme indicam os testes de White, porém, o teste KB indica que, para o ambiente mexicano, os resíduos do modelo proposto são homoscedásticos; 
e) Ausência de correlação serial: baseado no teste de correlação serial LM BreuschGodfrey, no Brasil e México existem evidências significativas de ausência de autocorrelação, ao nível de 5\%, porém pelo teste de Durbin-Watson, observa-se a ausência de autocorrelação para as companhias chilenas, mexicanas e peruanas, ao passo que em relação as brasileiras e norte-americanas, esse teste é inconclusivo;

f) Multicolineariedade: o modelo proposto apresentou, conforme indicam os testes Variance Inflation Factor, multicolineariedade acima do nível aceitável nas variáveis explicativas Rit e $C D_{i t}$ em todas as amostras, enquanto, no ambiente brasileiro, esse fato também ocorreu nas $F C O_{i t}$ e $A b_{-} C F O_{i t}$.

Apesar de as evidências mostrarem que os pressupostos da normalidade, homoscedasticidade e ausência de autocorrelação não foram atendidos plenamente em todos os ambientes, esses podem ser relaxados nas inferências sobre os parâmetros dos modelos, pois, segundo Wooldridge (2002) e Greene (2003), seus coeficientes são consistentes e não-viesados assintoticamente, mas deixam de ser os melhores estimadores lineares não-viesados (best linear unbiased estimator - BLUE).

Nas seções anteriores, verificou-se que não existem evidências claras sobre a utilidade das proxies do nível de conservadorismo sobre o comportamento dos accruals. Isso se deve ao fato de que em alguns ambientes econômicos ela foi relevante para o modelo proposto, como no Brasil, Chile e para amostra com todos os países, enquanto, no México, Peru e Estados Unidos da América, ela não foi significativamente relevante para a estimação.

Analisando-se, comparativamente, o modelo proposto com e sem o conjunto de proxies em relação ao efeito do conservadorismo na estimação dos accruals (respectivamente Tabelas 78 e 79), observa-se que o grau de ajuste do modelo para cada ambiente econômico é diferentemente afetado pela inclusão dessas variáveis.

A estimação do modelo proposto sem as variáveis para controlar o conservadorismo apresentou modificações significativas sobre o teste $t$ dos coeficientes. No Brasil, os coeficientes das variáveis $E_{i t}$ e $a b_{-} C F O_{i t}$ tornaram-se variáveis significativamente iguais a zero, ocorrendo o mesmo na amostra geral com relação à variável $E_{i t}$. Já na amostra das companhias chilenas, a exclusão dessas variáveis fez com que as variáveis $E_{i t}$ e $T A_{i t-1}$ se tornassem variáveis relevantes. Ainda, no contexto geral, a variável $A b_{-} D O_{i t}$ tornou-se significativamente diferente de zero. 
Tabela 78 - Comparação das estatísticas do modelo proposto

\begin{tabular}{|c|c|c|c|c|c|c|c|c|c|c|c|c|}
\hline & \multicolumn{2}{|c|}{ Brasil } & \multicolumn{2}{|c|}{ Chile } & \multicolumn{2}{|c|}{ México } & \multicolumn{2}{|c|}{ Peru } & \multicolumn{2}{|c|}{ EUA } & \multicolumn{2}{|c|}{ Geral } \\
\hline & coeficiente & p-value & coeficiente & p-value & coeficiente & p-value & coeficiente & p-value & coeficiente & p-value & coeficiente & p-value \\
\hline Constante & 0,050 & 0,012 & 0,052 & 0,258 & $-0,030$ & 0,093 & 0,051 & 0,235 & $-0,006$ & 0,381 & 0,066 & 0,011 \\
\hline $\mathrm{R}_{\mathrm{it}}$ & 0,470 & 0,001 & 0,119 & 0,638 & 0,529 & 0,000 & 0,685 & 0,000 & 0,280 & 0,000 & 0,309 & 0,000 \\
\hline $\mathrm{CD}_{\text {it }}$ & $-0,419$ & 0,004 & $-0,154$ & 0,539 & $-0,543$ & 0,000 & $-0,771$ & 0,000 & $-0,247$ & 0,000 & $-0,310$ & 0,000 \\
\hline $\mathrm{AI}_{\mathrm{it}}$ & $-0,010$ & 0,532 & $-0,110$ & 0,000 & 0,028 & 0,132 & $-0,190$ & 0,009 & $-0,035$ & 0,000 & $-0,040$ & 0,006 \\
\hline $\mathrm{AD}_{\text {it }}$ & $-0,006$ & 0,895 & 0,124 & 0,766 & $-0,035$ & 0,312 & 0,143 & 0,305 & $-0,004$ & 0,921 & $-0,759$ & 0,337 \\
\hline $\mathrm{FCO}_{\text {it }}$ & $-3,909$ & 0,196 & $-0,030$ & 0,947 & 0,083 & 0,828 & $-1,427$ & 0,000 & $-1,048$ & 0,000 & $-0,873$ & 0,044 \\
\hline $\mathrm{E}_{\mathrm{it}}$ & 0,294 & 0,000 & 0,439 & 0,186 & 0,333 & 0,000 & 0,505 & 0,000 & 0,261 & 0,000 & 0,285 & 0,000 \\
\hline $\mathrm{E}^{2}{ }_{\text {it }}$ & 0,031 & 0,001 & 0,071 & 0,382 & $-0,102$ & 0,001 & $-0,605$ & 0,107 & 0,037 & 0,000 & 0,037 & 0,000 \\
\hline $\mathrm{TA}_{\text {it-1 }}$ & $-0,063$ & 0,000 & 0,176 & 0,239 & 0,035 & 0,748 & 0,147 & 0,217 & $-0,013$ & 0,231 & $-0,067$ & 0,000 \\
\hline$\Delta \mathrm{E}_{\mathrm{t}-1}$ & $-0,014$ & 0,271 & $-0,022$ & 0,016 & 0,004 & 0,691 & $-0,001$ & 0,938 & $-0,003$ & 0,489 & $-0,019$ & 0,001 \\
\hline $\mathrm{D} \Delta \mathrm{E}_{\mathrm{it}-1}$ & $-0,237$ & 0,213 & 0,073 & 0,799 & $-0,044$ & 0,715 & $-0,302$ & 0,208 & $-0,014$ & 0,793 & $-0,039$ & 0,681 \\
\hline$\Delta \mathrm{E}_{\mathrm{it}-1}^{*} \mathrm{D} \Delta \mathrm{E}_{\mathrm{it}-1}$ & 0,080 & 0,128 & $-0,079$ & 0,014 & $-0,032$ & 0,552 & $-0,040$ & 0,233 & 0,071 & 0,000 & 0,047 & 0,042 \\
\hline $\mathrm{Ab} \_\operatorname{Prod}_{\mathrm{it}}$ & 4,557 & 0,137 & $-0,019$ & 0,679 & 0,039 & 0,116 & 0,209 & 0,005 & 0,057 & 0,000 & 0,075 & 0,105 \\
\hline $\mathrm{Ab} \_\mathrm{DO}_{\mathrm{it}}$ & $-0,028$ & 0,060 & $-0,001$ & 0,967 & 0,032 & 0,287 & $-0,050$ & 0,036 & 0,037 & 0,000 & 0,008 & 0,362 \\
\hline $\mathrm{Ab} \_\mathrm{CFO}_{\text {it }}$ & $-1,143$ & 0,001 & $-0,605$ & 0,173 & $-0,677$ & 0,083 & 0,495 & 0,008 & 0,612 & 0,009 & 0,366 & 0,402 \\
\hline$R^{2}$ & 0,400 & & 0,203 & & 0,448 & & 0,741 & & 0,343 & & 0,301 & \\
\hline$R^{2}$ ajustado & 0390 & & 0,181 & & 0,433 & & 0,732 & & 0,339 & & 0,298 & \\
\hline Estatística $F$ & $-0,886$ & 0,000 & 9,107 & 0,000 & 29,410 & 0,000 & 81,895 & 0,000 & 78,502 & 0,000 & 101,395 & \\
\hline White Test & 1280,950 & 0,000 & 197,838 & 0,000 & 972,151 & 0,000 & 693,268 & 0,000 & 1304,910 & 0,000 & 3252,860 & 0,000 \\
\hline KB Test & 0,757 & 0,000 & 2,394 & 0,000 & 0,072 & 0,222 & 0,964 & 0,000 & 0,092 & 0,000 & 0,928 & 0,000 \\
\hline Durbin-Watson & 1,745 & & 2,008 & & 2,025 & & 1,849 & & 1,773 & & 1,839 & \\
\hline Breusch-Godfrey Test & 50,765 & 0,395 & 10,954 & 0,004 & 5,063 & 0,080 & 6,417 & 0,040 & 11,246 & 0,004 & 83,397 & 0,000 \\
\hline Jarque-Bera Test & 391920 & 0,000 & 1387719 & 0,000 & 29758,380 & 0,000 & 13267 & 0,000 & 61046 & 0,000 & 7969443 & 0,000 \\
\hline Observações & 2464 & & 1396 & & 1082 & & 861 & & 4840 & & 10422 & \\
\hline
\end{tabular}

Modelo proposto: $T A_{i t}=\alpha+\beta_{1} R_{i t}+\beta_{2} C D_{i t}+\beta_{2} A I_{i t}+\beta_{2} A D_{i t}+\lambda_{1} F C O_{i t}+\lambda_{2} E_{i t}+\lambda_{3} E_{i t}^{2}+\lambda_{4} \Delta E_{i t}+\lambda_{5} D \Delta E_{i t}+\lambda_{6} \Delta E_{i t}{ }^{*} D \Delta E_{i t}+\lambda_{7} T A_{i t-1}+\gamma_{1} a b \_P r o d_{i t}+\gamma_{2} a b \_D O_{i t}+\gamma_{3} a b \_C F O_{i t}+\varepsilon_{i t}$.

Em que: $T A_{i t}=$ accruals totais da empresa no período $t ; R_{i t}=$ receitas das vendas líquidas da empresa $i$ no período $t$, ponderadas pelos ativos totais no final do período $t$ - 1 ; $C D_{i t}=$ custos e despesas operacionais da empresa $i$ no período $t$, excetuando-se as despesas financeiras e despesas com depreciação, exaustão e amortização, ponderadas pelos ativos totais no final do período $t-1 ; A I_{i t}=$ ativo imobilizado da empresa $i$ no final do período $t-1$, ponderado pelos ativos totais no final do período $t$ - $1 ; A D_{i t}=$ ativo diferido no final da empresa $i$ no final do período $t-1$, ponderado pelos ativos totais no final do período $t-1 ; F C O_{i t}=$ fluxo de caixa operacional da empresa $i$ no período $t$, ponderado pelos ativos totais no final do período $t-1 ; E_{i t}=$ resultado contábil da empresa $i$ no período $t$, ponderado pelos ativos totais no final do período $t-1 ; \Delta E_{i t}=$ variação no lucro líquido contábil da empresa $i$ do ano $t-2$ para o ano $t-1$ ponderada pelo valor do ativo total no início do ano $t-1 ; D \Delta E_{i t-1}=$ variável $d u m m y$ para indicar se existe variação negativa no lucro líquido contábil da empresa $i$ do ano $t$ - 1 para o ano $t$, assumindo valor 1 se $\Delta N I_{i t}<0$, e 0 nos demais casos; $T A_{i t-1}=a c c r u a l s$ totais da empresa $i$ no

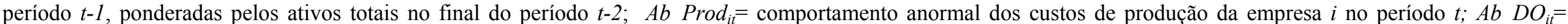
comportamento anormal das despesas operacionais da empresa $i$ no período $t ; A b_{-} C F O_{i t}=$ comportamento anormal das despesas operacionais da empresa $i$ no período $t$; $\varepsilon_{i t}=$ erro da regressão; $\alpha, \beta$ 's, $\lambda$ 's e $\gamma^{\prime} s=$ coeficientes estimados da regressão. 
Tabela 79 - Comparação das estatísticas do modelo proposto sem conservadorismo

\begin{tabular}{|c|c|c|c|c|c|c|c|c|c|c|c|c|}
\hline & \multicolumn{2}{|c|}{ Brasil } & \multicolumn{2}{|c|}{ Chile } & \multicolumn{2}{|c|}{ México } & \multicolumn{2}{|c|}{ Peru } & \multicolumn{2}{|c|}{ EUA } & \multicolumn{2}{|c|}{ Geral } \\
\hline & coeficiente & p-value & coeficiente & p-value & coeficiente & p-value & coeficiente & p-value & coeficiente & p-value & coeficiente & p-value \\
\hline Constante & 0,048 & 0,024 & 0,066 & 0,002 & $-0,024$ & 0,030 & 0,056 & 0,221 & $-0,007$ & 0,299 & 0,048 & 0,055 \\
\hline $\mathrm{R}_{\mathrm{it}}$ & 0,693 & 0,000 & $-0,008$ & 0,971 & 0,515 & 0,000 & 0,683 & 0,000 & 0,283 & 0,000 & 0,361 & 0,000 \\
\hline $\mathrm{CD}_{\text {it }}$ & $-0,671$ & 0,000 & $-0,014$ & 0,951 & $-0,531$ & 0,000 & $-0,767$ & 0,000 & $-0,252$ & 0,000 & $-0,360$ & 0,000 \\
\hline $\mathrm{AI}_{\mathrm{it}}$ & $-0,021$ & 0,234 & $-0,116$ & 0,000 & 0,026 & 0,124 & $-0,193$ & 0,011 & $-0,036$ & 0,000 & $-0,042$ & 0,007 \\
\hline $\mathrm{AD}_{\text {it }}$ & $-0,018$ & 0,669 & 0,212 & 0,599 & $-0,034$ & 0,312 & 0,167 & 0,234 & $-0,004$ & 0,927 & $-0,831$ & 0,324 \\
\hline $\mathrm{FCO}_{\text {it }}$ & $-2,200$ & 0,391 & $-0,298$ & 0,361 & 0,106 & 0,785 & $-1,431$ & 0,000 & $-1,014$ & 0,000 & $-0,792$ & 0,060 \\
\hline $\mathrm{E}_{\text {it }}$ & 0,005 & 0,946 & 0,634 & 0,020 & 0,343 & 0,000 & 0,487 & 0,000 & 0,246 & 0,000 & 0,092 & 0,282 \\
\hline $\mathrm{E}^{2}{ }_{\text {it }}$ & 0,017 & 0,032 & 0,079 & 0,393 & $-0,093$ & 0,000 & $-0,415$ & 0,199 & 0,039 & 0,000 & 0,020 & 0,041 \\
\hline $\mathrm{TA}_{\mathrm{it}-1}$ & 0,161 & 0,049 & $-0,103$ & 0,004 & $-0,034$ & 0,535 & $-0,040$ & 0,226 & 0,072 & 0,000 & 0,071 & 0,013 \\
\hline $\mathrm{Ab} \_\operatorname{Prod}_{i t}$ & 2,483 & 0,356 & $-0,037$ & 0,426 & 0,040 & 0,109 & 0,207 & 0,004 & 0,058 & 0,000 & 0,067 & 0,156 \\
\hline $\mathrm{Ab}_{-} \mathrm{DO}_{\text {it }}$ & $-0,008$ & 0,621 & $-0,027$ & 0,148 & 0,028 & 0,406 & $-0,052$ & 0,026 & 0,040 & 0,000 & 0,020 & 0,028 \\
\hline $\mathrm{Ab}_{-} \mathrm{CFO}_{\text {it }}$ & $-0,792$ & 0,080 & $-0,372$ & 0,170 & $-0,700$ & 0,079 & 0,498 & 0,006 & 0,585 & 0,008 & 0,356 & 0,406 \\
\hline$R^{2}$ ajustado & 0,308 & & 0,160 & & 0,433 & & 0,740 & & 0,339 & & 0,248 & \\
\hline Estatística $F$ & 30,695 & 0,000 & 11,200 & 0,000 & 32,780 & 0,000 & 91,294 & 0,000 & 86,563 & 0,000 & 84,723 & 0,000 \\
\hline White Test & 2206,035 & 0,000 & 833,114 & 0,000 & 950,910 & 0,000 & 654,716 & 0,000 & 1024,537 & 0,000 & 3552,084 & 0,000 \\
\hline KB Test & 1,065 & 0,000 & 1,992 & 0,000 & 0,073 & 0,220 & 0,030 & 0,000 & 0,092 & 0,000 & 0,741 & 0,000 \\
\hline Durbin-Watson & 1,895 & & 1,985 & & 2,022 & & 1,853 & & 1,780 & & 1,869 & \\
\hline Breusch-Godfrey Test & 3,462 & 0,177 & 20,669 & 0,000 & 4,297 & 0,117 & 6,135 & 0,047 & 10,616 & 0,005 & 28,641 & 0,000 \\
\hline Jarque-Bera Test & 425480 & 0,000 & 1571567 & 0,000 & 31171 & 0,000 & 13491 & 0,000 & 609953 & 0,000 & 7825132 & 0,000 \\
\hline Observações & 2464 & & 1396 & & 1082 & & 861 & & 4842 & & 10424 & \\
\hline
\end{tabular}

Modelo proposto: $T A_{i t}=\alpha+\beta_{1} R_{i t}+\beta_{2} C D_{i t}+\beta_{2} A I_{i t}+\beta_{2} A D_{i t}+\lambda_{1} F C O_{i t}+\lambda_{2} E_{i t}+\lambda_{3} E_{i t}^{2}+\lambda_{7} T A_{i t-1}+\gamma_{1} a b$ Prod $_{i t}+\gamma_{2} a b D_{i t} O_{i t}+\gamma_{3} a b C C F O_{i t}+\varepsilon_{i t}$.

Em que: $T A_{i t}=$ accruals totais da empresa no período $t ; R_{i t}=$ receitas das vendas líquidas da empresa $i$ no período $t$, ponderadas pelos ativos totais no final do período $t-1$; $C D_{i t}=$ custos e despesas operacionais da empresa $i$ no período $t$, excetuando-se as despesas financeiras e despesas com depreciação, exaustão e amortização, ponderadas pelos ativos totais no final do período $t-1 ; A I_{i t}=$ ativo imobilizado da empresa $i$ no final do período $t-1$, ponderado pelos ativos totais no final do período $t-1 ; A D_{i t}=$ ativo diferido no final da empresa $i$ no final do período $t-1$, ponderado pelos ativos totais no final do período $t$ - $1 ; F C O_{i t}=$ fluxo de caixa operacional da empresa $i$ no período $t$, ponderado pelos ativos totais no final do período $t-1 ; E_{i t}=$ resultado contábil da empresa $i$ no período $t$, ponderado pelos ativos totais no final do período $t-1 ; T A_{i t-1}=$ accruals totais da empresa $i$ no período $t$ - 1 , ponderadas pelos ativos totais no final do período $t$-2; $A b \_\operatorname{Prod}_{i t}=$ comportamento anormal dos custos de produção da empresa $i$ no período $t$; $A b_{-} D O_{i t} \quad=$ comportamento anormal das despesas operacionais da empresa $i$ no período $t ; A b_{-} C F O_{i t}=$ comportamento anormal das despesas operacionais da empresa $i$ no período $t ; \varepsilon_{i t}=$ erro da regressão; $\alpha, \beta^{\prime} s$, $\lambda^{\prime} s$ e $\gamma^{\prime} s=$ coeficientes estimados da regressão. 
Após as exclusões das variáveis $\Delta E_{i t-1}, D \Delta E_{i t-1}$ e $\Delta E_{i t-1}{ }^{*} D \Delta E_{i t-1}$, verificou-se, nesta pesquisa, que a variável 'ativo diferido' $\left(A D_{i t}\right)$ continua apresentando coeficiente igual a zero em todas as amostras. Por outro lado, a variável 'ativo imobilizado' $\left(A I_{i t}\right)$ é relevante em todos os ambientes econômicos, exceto no contexto brasileiro.

Assim, sem as variáveis $\Delta E_{i t-1}, D \Delta E_{i t-1}$ e $\Delta E_{i t-1}{ }^{*} D \Delta E_{i t-1}$, e $A D_{i t}$, o modelo proposto continuaria apresentando resíduos heteroscedásticos em todos os ambientes econômicos, com exceção ao México, e autocorrelacionados.

Os coeficientes de determinação ajustados ( $R^{2}$ ajustado) com essa especificação é de 0,291 para as companhias brasileiras, de 0,159 para as companhias chilenas, de 0,433 para as companhias mexicanas, de 0,732 para as companhias peruanas, de 0,339 para as companhias norte-americanas e para a amostra total de 0,247. Os testes com as amostras com empresas brasileiras, chilenas e geral identificam que houve uma redução do grau de ajustamento, enquanto nas demais amostras não ocorreram alterações significativas no $R^{2}$ ajustado.

Mas, a variável $P P E_{i t}$, que é uma agregação das duas variáveis, presente nos modelos Jones, Jones Forward Looking e Pae, foi significativa em todos os ambientes econômicos estudados, com exceção do peruano. Portanto, diante da evidência de relevância da variável $P P E_{i t} \mathrm{e}$ devido à importância (pelo menos teórica) das despesas de depreciação e amortização na formação dos accruals no resultado do exercício, considerou-se relevante o emprego alternativo dessa proxy em substituição das variáveis $A I_{i t}$ e $A D_{i t}$ no modelo proposto, pois auxilia na estimação dos accruals.

Com relação às demais variáveis do modelo proposto, observe-se que, em algumas amostras, se mostram relevantes na especificação, ao passo que para outras se apresentam irrelevantes, assim a sua exclusão depende fortemente do ambiente analisado e das hipóteses levantadas nos estudos. Resumidamente, têm-se que:

a) Receita liquidas $\left(R_{i t}\right)$ : essa variável tem relevância em todas as amostras, mas ao mesmo tempo, apresenta problema de multicolineariedade com a variável $C D_{i t}$;

b) Custos e Despesas $\left(C D_{i t}\right)$ : variável relevante, porém, como descrito no item anterior, tem problema de multicolineriedade com $R_{i t}$, mas, apesar de uma pequena perda no grau de ajustamento do modelo proposto, a sua exclusão do modelo proposto elimina os problemas originados pela multicolineariedade;

c) Ativo Imobilizado $\left(A I_{i t}\right)$ : essa variável só não tem coeficiente significativamente diferente de zero no ambiente brasileiro e sua exclusão afeta significativamente o poder preditivo do modelo; 
d) Ativo Diferido $\left(A D_{i t}\right)$ : essa variável não foi relevante em todas as amostras e sua exclusão não afeta significativamente o poder preditivo do modelo, portanto, pode ser eliminada do modelo ou, de forma alternativa, substituí-la e à $A I_{i t}$ pela variável $P P E_{i t}$;

e) Fluxo de caixa operacional $\left(F C O_{i t}\right)$ : essa variável tem coeficiente significativamente diferente de zero nas amostras com as companhias peruanas e estadunidenses, bem como para a amostra geral, porém apresenta problema de multicolineariedade com a variável $A b_{-} C F O_{i t}$;

f) Resultado líquido $\left(E_{i t}\right)$ : essa variável só não tem coeficiente significativamente diferente de zero no ambiente chileno;

g) Resultado líquido ao quadrado $\left(E^{2}{ }_{i t}\right)$ : essa variável só não tem coeficiente significativamente diferente de zero nas amostras com companhias chilenas e peruanas;

h) Accruals totais defasados $\left(T A_{i t-1}\right)$ : essa variável tem somente coeficiente significativamente diferente de zero no contexto brasileiro e com a amostra que inclui as empresas de todos os países analisados;

i) Nível de conservadorismo $\left(\Delta E_{i t-1}, D \Delta E_{i t-1}\right.$ e $\left.\Delta E_{i t-1}{ }^{*} D \Delta E_{i t-1}\right)$ : o conjunto de variáveis para controlar o nível de conservadorismo das empresas foi relevante para o modelo proposto no Brasil, Chile e para a amostra com todos os países;

j) Comportamento anormal dos custos de produção ( $\left.A b_{-} \operatorname{Prod}_{i t}\right)$ : essa variável foi estatisticamente significante nos contextos peruano e norte-americano;

k) Comportamento anormal das despesas operacionais $\left(A b_{-} D O_{i t}\right)$ : da mesma forma que o item anterior, essa variável foi estatisticamente significante nos contextos peruano e norte-americano;

1) Comportamento anormal do fluxo de caixa operacional $\left(A b_{-} C F O_{i t}\right)$ : essa variável foi estatisticamente significante nos contextos brasileiro, peruano e norte-americano, mas apresenta multicolineariedade com a variável $C F O_{i t}$. Apesar de uma pequena perda no poder preditivo, o comportamento anormal do caixa operacional pode ser captado pelo modelo através da $C F O_{i t}$, e, portanto, a sua exclusão resolve os problemas originados da multicolineariedade, sem grandes prejuízos para a capacidade preditiva do modelo proposto;

m) Setores de atividades econômicas: as variáveis dummies para cada setor tiveram significâncias distintas em cada contexto analisado nessa pesquisa, sendo que em alguns casos, os coeficientes foram expressivos. 
A inclusão de variável irrelevante (superespecificação) no modelo não tem nenhum efeito em termos de viés em $\beta$, porém aumenta a variância dos estimadores do MQO. A relevância desse aumento da variância dos estimadores decresce à medida que aumenta o tamanho da amostra (MADALLA, 1992, p.164-165; WOOLDRIDGE, 2002, p.87-100; GREENE, 2003, p.151).

Diante da necessidade de ajustes, o modelo operacional proposto, anteriormente descrito, pode ser mais bem especificado da seguinte forma:

$$
\begin{gathered}
T A_{i t}=\alpha+\beta_{1} R_{i t}+\beta_{2} A I_{i t}+\lambda_{1} F C O_{i t}+\lambda_{2} E_{i t}+\lambda_{3} E_{i t}^{2} ;+\lambda_{4} \Delta E_{i t-1}+\lambda_{5} D \Delta E_{i t-1}+ \\
\lambda_{.6} \Delta E_{i t-1} * D \Delta E_{i t-1} \lambda_{7} T A_{i t-1}+\gamma_{1} a b_{-} \operatorname{Pr} o d_{i t}+\gamma_{2} a b_{-} D O_{i t}+\varepsilon_{i t}
\end{gathered}
$$

em que:

$T A_{i t} \quad=$ accruals totais da empresa $i$ no período $t$;

$R_{i t} \quad=$ receitas das vendas líquidas da empresa $i$ no período $t$, ponderadas pelos ativos totais no final do período $t-1$;

$A I_{i t} \quad=$ ativo imobilizado da empresa $i$ no final do período $t$, ponderado pelos ativos totais no final do período $t-1$;

$F C O_{i t}=$ fluxo de caixa operacional da empresa $i$ no período $t$, ponderado pelos ativos totais no final do período $t-1$;

$E_{i t} \quad=$ resultado contábil da empresa $i$ no período $t$, ponderado pelos ativos totais no final do período $t-1$;

$\Delta E_{i t-1}=$ variação no lucro líquido contábil da empresa $i$ do ano $t$-2 para o ano $t-1$ ponderada pelo valor do ativo total no início do ano $t-2$;

$D \Delta E_{i t-1} \quad=$ variável dummy para indicar se existe variação negativa no lucro líquido contábil da empresa $i$ do ano $t-2$ para o ano $t-1$, assumindo valor 1 se $\Delta N I_{i t}<0$, e 0 nos demais casos;

$T A_{t-1}=$ accruals totais da empresa $i$ no período $t-1$, ponderados pelos ativos totais no final do período $t-2$;

$A b \_\operatorname{Prod}_{i t}=$ comportamento anormal dos custos de produção da empresa $i$ no período $t$;

$A b_{-} D O_{i t}=$ comportamento anormal das despesas operacionais da empresa $i$ no período $t$;

$\varepsilon_{i t} \quad=$ erro da regressão;

$\alpha, \beta$ 's, $\lambda$ 's e $\gamma^{\prime} s \quad=$ coeficientes estimados da regressão. 


\section{CONSIDERAÇÕES FINAIS}

Este estudo buscou contribuir para a reflexão e discussão sobre a qualidade das informações contábeis, por meio da compreensão dos fatores institucionais que influenciam o processo de mensuração e evidenciação dos números contábeis e a tomada de decisão dos agentes econômicos.

A compreensão da qualidade das informações contábeis é de extrema importância, pois auxilia a análise econômica e financeira das empresas, contribuindo, principalmente, para a alocação dos recursos financeiros, para o estabelecimento das relações contratuais e para o processo regulatório da Contabilidade. A literatura internacional, conforme apresentado no referencial teórico deste trabalho, destaca diversas dimensões da qualidade informacional da Contabilidade, dentre as quais têm-se: o conservadorismo, a persistência e a manipulação das informações contábeis.

Este trabalho teve como foco o estudo sobre a manipulação das informações contábeis, aqui descrita como conjunto de práticas desenvolvidas pelos administradores, seja através das escolhas contábeis ou alteração das atividades operacionais (reais) normais da empresa, com o objetivo de interferir, intencionalmente, na informação contábil reportada e, conseqüentemente, afetar a análise do desempenho da empresa ou influenciar as relações contratuais que dependam dos números contábeis.

Especificamente, buscou-se avaliar, criticamente, os modelos operacionais da literatura corrente que são utilizados nas pesquisas empíricas para identificar a prática discricionária dos gestores sobre o processo de mensuração e divulgação dos números contábeis.

A capacidade preditiva dos modelos analíticos-empíricos é uma preocupação constante nas pesquisas contábeis, pois, à medida que se analisam as hipóteses de pesquisa, ao mesmo tempo se verifica a validade empírica do modelo operacional (teste de hipóteses conjuntas). Entretanto, apesar da preocupação com a validade teórica e empírica, poucos trabalhos científicos apresentam novos modelos ou novas abordagens metodológicas para contribuir com a compreensão da influência dos fatores institucionais e organizacionais sobre os números contábeis, bem como para o entendimento da relação entre os agentes econômicos e a informação contábil. 
Com base nas evidências apresentadas no capítulo anterior, uma pergunta poderia ser feita: Por que os modelos operacionais, em particular, os modelos para a estimação dos accruals, têm desempenhos tão diferentes entre os ambientes econômicos analisados?

A discussão sobre esse ponto foi apresentada na revisão teórica, na qual se afirma que diferenças existentes entre os países em relação aos sistemas contábeis, desempenho econômico, características institucionais e o ambiente social, legal e político, influenciam o processo de mensuração e evidenciação das informações contábeis.

Como pode ser observado no decorrer deste estudo, existe a necessidade de as pesquisas contábeis realizarem uma visão autocrítica do que tem sido feito e analisar as demandas e idiossincrasias de cada ambiente econômico, estabelecendo hipóteses ainda não levantadas e desenvolvendo modelos teóricos e empíricos mais abrangentes.

Este estudo teve como principal preocupação a utilização dos modelos teóricos e operacionais para a detecção de gerenciamento de resultados, especificamente, o objeto de estudo foi o conjunto de modelos operacionais para a estimação dos accruals discricionários.

Cabe lembrar que os modelos operacionais de estimação de accruals são utilizados para calcular o componente discricionário dos accruals totais. Os accruals discricionários são considerados como proxy para o modelo geral para a detecção de gerenciamento de resultados, e são regredidos contra os diversos fatores que presumidamente incentivam o gerenciamento de resultados. Caso a estimativa do parâmetro que representa o incentivo analisado seja significativamente diferente de zero, considera-se que existem evidências de gerenciamento de resultados contábeis.

Apesar de não ser o foco deste estudo, conforme discutido e apresentado no Capítulo 3, o modelo teórico (Equação 3.02) proposto por McNichols e Wilson (1988), para detectar o gerenciamento dos accruals, não incorpora a interação entre as diversas formas de gerenciamento de resultados e os custos associados à manipulação das informações contábeis. Para tanto, este trabalho apresentou uma especificação teórica mais abrangente para a detecção de gerenciamento de accruals por meio das escolhas contábeis (Equação 4.07), considerando os incentivos simultâneos e a influência dos custos associados ao gerenciamento de resultados, partindo da premissa de que a manipulação das informações através das escolhas contábeis é realizada posteriormente ao gerenciamento das atividades operacionais. Porém, os trabalhos posteriores devem aperfeiçoar a especificação desse constructo teórico e desenvolver proxies operacionais para viabilizar a utilização do modelo, principalmente, no que se refere às medidas de mensuração dos incentivos e custos associados às práticas discricionárias. 
Com o intuito de verificar a relação do resultado contábil, fluxo de caixa e accruals, adicionalmente, foi efetuada a análise de correlação dessas variáveis. Foram apresentadas evidências que confirmam algumas predições de Dechow e Dichev (2002), em particular, a correlação negativa significativa dos accruals totais corrente $\left(T A_{t}\right)$ com o fluxo de caixa corrente $\left(F C O_{t}\right)$ e a existência de correlação positiva entre os accruals totais corrente $\left(T A_{t}\right)$ e o resultado líquido corrente $\left(E_{t}\right)$, que comprovam a influência dessas variáveis na estimação dos accruals não-discricionários e discricionários. Porém, não foi comprovada a correlação negativa dos accruals totais defasados $\left(T A_{t-1}\right)$ e os accruals totais correntes $\left(T A_{t}\right)$. Torna-se, portanto, oportuno que outros trabalhos analisem as relações entre o resultado contábil e seus componentes.

Analisando-se, especificamente, os modelos operacionais existentes na literatura, observou-se que, ao longo do tempo, esses sofreram críticas e modificações em suas especificações para captar de forma mais adequada o comportamento dos accruals e identificar os seus componentes não-discricionários e discricionários. Essa análise crítica faz parte do processo científico de modo a aperfeiçoar e ampliar o conjunto de conhecimentos estabelecidos.

Dentre as principais observações apontadas neste trabalho sobre a especificação dos modelos existentes na literatura corrente, destacam-se:

a) Os modelos não controlam adequadamente as mudanças causadas pelas condições econômicas;

b) Os modelos não consideram as mudanças normais das atividades operacionais da empresa;

c) Os modelos não controlam a variação dos preços ao longo do tempo;

d) As variáveis utilizadas para controlar o ambiente econômico podem estar contaminadas pelo gerenciamento de resultados;

e) Algumas variáveis conduzem à identificação de accruals discricionários, mesmo que tal prática não ocorra;

f) Os resíduos podem ser serialmente correlacionados, devido à auto-reversão dos accruals nos períodos subseqüentes;

g) Os modelos não controlam diretamente os desempenhos extremos dos fluxos de caixa e dos resultados;

h) O modelo Jones e seus desdobramentos não têm termo constante na especificação, o que afeta diretamente a estimação dos testes estatísticos;

i) Os modelos não controlam o comportamento conservador do ambiente contábil analisado; 
j) Os modelos assumem que o comportamento dos accruals totais tem relação linear com o incentivo.

Diante da análise teórica da especificação de cada modelo descrito na literatura corrente e observação de evidências empíricas em diversos trabalhos anteriores que estudam o comportamento (oportunístico ou não) dos accruals, foi proposto um modelo para a estimação dos accruals (seção 3.6).

Na seção 5.2, apresentaram-se evidências de que os modelos operacionais para a estimação dos accruals, de forma geral, apresentam baixo poder explicativo. O modelo Setorial pode ser considerado o de menor capacidade preditiva para analisar os accruals. As estimações efetuadas para as amostras com as companhias peruanas têm maior poder preditivo se comparadas aos demais ambientes empresariais, enquanto as realizadas no ambiente chileno têm as mais fracas estimativas para a maioria dos modelos.

O modelo proposto, com ou sem as proxies para gerenciamento de atividades operacionais, apresentou-se como o de melhor especificação entre os diversos modelos analisados neste estudo em todos os ambientes econômicos.

Particulamente no ambiente brasileiro, o modelo proposto tem um poder preditivo muito superior em relação aos demais modelos, sendo que alguns desses não apresentam grau de ajustamento significativo para analisar o comportamento dos accruals das companhias brasileiras.

Observe-se, também, que existe uma grande volatilidade do poder preditivo de cada modelo quando da análise comparativa nos diversos países. Essa evidência sugere que, para a utilização ou não de um determinado modelo, se deve avaliar inicialmente o contexto econômico, os fatores institucionais e organizacionais e as hipóteses a serem testadas com o propósito de empregar o modelo mais adequado para o objetivo da pesquisa.

A falha da estimação dos modelos operacionais em ambientes econômicos diferentes pode ser observada, neste trabalho, pelo modelo Jones Forward Looking. O modelo Jones Forward Looking é único que apresenta alguma variável relacionada ao período subseqüente $\left(C r R_{i t+1}\right)$ na sua especificação.

Essa variável do modelo Jones FL somente foi relevante na amostra que compreende as companhias abertas norte-americanas, entretanto, em outros ambientes econômicos, ela não se apresentou estatisticamente significante para a estimação dos accruals.

Esses resultados podem sugerir a necessidade de especificação de modelos operacionais que atendam às idiossincrasias nacionais, como, nesse caso, em que se evidencia uma 
característica peculiar dos números contábeis reportados em um mercado de capitais desenvolvido (EUA), que não é observado nos demais mercados considerados menos desenvolvidos. Tal característica pode estar relacionada com o fato de que os participantes do mercado estadunidense necessitem de maiores informações sobre desempenho futuro das empresas, o que seria transmitido pelos administradores através dos accruals discricionários (perspectiva de eficiência).

Outra característica da informação contábil discutida e analisada nesta pesquisa foi o conservadorismo e sua influência na mensuração contábil. Diante da sua relevância no sistema contábil, o modelo proposto incorporou a proxy de nível de conservadorismo proposto por Ball e Shivakumar (2005).

A inclusão do conjunto de variáveis que capturam a influência do nível de conservadorismo no comportamento dos accruals mostrou-se inconclusiva, pois, somente em alguns ambientes, foi considerada relevante, conforme apresentado no Capítulo 5 deste trabalho. Entretanto, torna-se importante que os pesquisadores utilizem alguma proxy para controlar o nível de conservadorismo em ambientes econômicos em que existem níveis de comportamento conservador significativamente diferentes entre as empresas ou grupos de empresas e, principalmente, em pesquisas que versem sobre as diferenças das caraterísticas das informações contábeis entre os diversos países.

Reciprocamente, os accruals discricionários devem ser controlados nos estudos sobre a influência do conservadorismo sobre os números contábeis, com o propósito de controlar o comportamento oportunístico dos administradores e, conseqüentemente, obter evidências mais adequadas nas pesquisas.

Com relação às proxies para capturar os efeitos do gerenciamento das atividades operacionais sobre o comportamento dos accruals, observou-se que as variáveis 'comportamento anormal dos custos de produção' e 'comportamento anormal das despesas operacionais' foram significantes em alguns ambientes. Essas evidências corroboram a suposição de que o gerenciamento das atividades operacionais afeta o comportamento dos accruals e, assim, devem ser controlados no modelo das estimações dos accruals discricionários originados das escolhas contábeis.

A proxy para o 'comportamento anormal do fluxo de caixa' foi relevante em alguns ambientes econômicos, mas apresentou problemas de multicolineariedade em relação à variável 'fluxo de caixa operacional'. Esse fato sugere que a variável 'fluxo de caixa operacional' captura, também, as práticas discricionárias de gerenciamento das atividades operacionais que afetam 
o fluxo de caixa da empresa. Portanto, ao ajustar o modelo proposto, optou pela retirada dessa variável.

Essas proxies, bem como as demais variáveis descritas no modelo proposto, devem ser examinadas em amostras diferentes para se verificar a sua validade empírica e, na medida do possível, se realizarem os ajustes necessários na especificação do modelo original.

Em resumo, os principais resultados desta pesquisa são:

a) $\mathrm{O}$ modelo geral para a detecção de gerenciamento de resultados proposto por McNichols e Wilson (1988) não incorpora a interação entre os diversos incentivos de gerenciamento de resultados e os custos associados na manipulação das informações contábeis;

b) Os modelos operacionais de estimação dos accruals discricionários, presentes na literatura corrente, não apresentam fundamentação teórica adequada, sendo que alguns desses modelos são pobremente especificados;

c) Os modelos operacionais de estimação dos accruals discricionários, presentes na literatura corrente, têm baixo poder preditivo, independentemente do ambiente econômico estudado;

d) O poder preditivo de cada modelo altera-se significativamente quando aplicado em ambientes econômicos diferentes;

e) O modelo operacional, proposto neste trabalho, para estimar os accruals discricionários utilizados na detecção de gerenciamento de resultados através das escolhas contábeis obteve o melhor poder explicativo do comportamento dos accruals totais.

A utilização do modelo geral para a detecção de gerenciamento de resultados pode levar o pesquisador a inferências errôneas sobre o fenômeno estudado, pois, ao ser analisado um único incentivo do gerenciamento de resultados, pode-se incorrer em omissão de variável relevante, o que afetará as estimativas dos parâmetros e testes dos modelos. Portanto, o modelo pode atribuir ou não, de forma errônea, a prática de gerenciamento de resultados ao incentivo testado.

Para minimizar os erros nas inferências nas pesquisas, sugere-se a utilização de um modelo que considere duas ou mais situações simultâneas e independentes e que conduzam ao gerenciamento de resultados, além de incorporar os custos associados às práticas discricionárias dos gestores.

Com relação à estimação dos accruals, o fraco poder preditivo dos modelos acarreta um maior volume de accruals discricionários, pois, quanto menor o grau de ajuste do modelo, 
maior será o montante dos resíduos. Conseqüentemente, a utilização do montante desses accruals discricionários como variável no modelo para a detecção de gerenciamento de resultados pode gerar evidências estatísticas enviesadas e inconsistentes.

Portanto, um modelo com maior poder preditivo para a estimação dos accruals discricionários minimiza o erro de mensuração nos modelos de detecção de gerenciamento de resultados. Torna-se oportuno comentar que o modelo proposto para estimar os accruals discrionários para detectar o gerenciamento de resultados, também pode ser empregado em outras pesquisas relacionadas à qualidade das informações contábeis, tanto no enfoque oportunístico, quanto no enfoque de eficiência, como, por exemplo, na avaliação do poder preditivo dos accruals discricionários na análise dos retornos anormais.

Como visto na seção 3.6, o modelo proposto minimiza alguns problemas apontados nas diversas pesquisas sobre o tema, em especial, observa a correlação entre os accruals, o fluxo de caixa operacional e resultado contábil, a reversão natural dos accruals, o nível de conservadorismo, a mudança de accruals originados das práticas de gerenciamento das atividades operacionais, além de ser especificado de modo a não afetar as estimativas dos testes estatísticos. Porém, como qualquer outra proposta, também apresenta algumas limitações, como:

a) Não controla plenamente os fatores econômicos que afetam as estimações dos accruals;

b) Avalia somente os accruals que têm efeitos de curto prazo;

c) As variáveis utilizadas podem estar contaminadas pelo gerenciamento de resultados e

d) Não ajusta a estimação dos accruals em relação à variação dos preços ao longo do tempo.

Uma forma de solucionar a limitação apontada no item $\mathrm{d}$, seria a avaliação dos accruals discricionários através das Demonstrações Contábeis mensuradas pela Correção Integral.

Portanto, observou-se que, em relação à Hipótese 1 deste trabalho, as evidências apresentadas sugerem que somente o modelo Pae e o proposto neste trabalho apresentam algum poder preditivo para explicar o comportamento dos accruals e estimar os accruals discricionários. Com relação à Hipótese 2, verificou-se que existem diferenças significativas no desempenho dos modelos e que eles variam significativamente conforme o ambiente analisado.

Por fim, para a Hipótese 3, observou-se que o modelo proposto para a mensuração dos accruals discricionários é mais bem especificado e tem maior poder preditivo do que os 
demais modelos concorrentes, independente do método de estimação (pooling of independent cross section, cross section ou dados em painel).

Por fim, considera-se como oportunidades para futuras pesquisas:

a) Estudos criticos sobre a validade teórica e empírica dos modelos operacionais utilizados nas pesquisas empíricas no contexto brasileiro;

b) Desenvolvimento de modelos teóricos e operacionais que capturem de forma mais adequada os fatores relevantes no processo de mensuração e evidência contábil;

c) Aperfeiçoamento do modelo geral para a detecção de gerenciamento de resultados através dos accruals e das atividades operacionais;

d) Desenvolvimento de proxies para custos associados à manipulação das informações contábeis para que se possa descrever o modelo operacional mais abrangente;

e) Testar hipóteses sobre a manipulação das informações contábeis ainda não estudadas profundamente no contexto brasileiro e/ou internacional, como, por exemplo, a influência do sistema tributário nos incentivos para o gerenciamento de resultados;

f) Estudos analíticos e empíricos sobre as demais formas de manipulação das informações contábeis;

g) Pesquisas mais abragentes sobre os incentivos e restrições para o gerenciamento de resultados em outros ambientes econômicos, como as companhias de capital fechado e as sociedades limitadas;

h) Pesquisas que analisem como o mercado identifica e como reage às boas ou más práticas de gerenciamento de resultados;

i) Estudos com uma discussão mais ampla sobre a manipulação das informações contábeis através das perspectivas oportunística e da eficiência.

Espera-se que este trabalho reforce a tese de que as abordagens normativa e positiva, quando utilizadas conjuntamente, auxiliam, de forma mais efetiva, as Ciências Contábeis; e, especificamente, contribua, de alguma forma, para o desenvolvimento dos estudos sobre as características das informações contábeis no Brasil, em particular, no que se refere à análise crítica da utilização de modelos operacionais empregados nas pesquisas empíricas. 


\section{REFERÊNCIAS}

AHMED, Anwer S. et al. Accounting conservatism and the valuation of accounting numbers: evidence on the Feltham-Ohlson (1996) model. Journal of Accounting, Auditing and Finance. New York: v. 15, n.3, p.271-292, summer 2000.

ALI, Ashiq; HWANG, Lee-Seok. Country-specific factors related to financial reporting and the value relevance of accounting data. Journal of Accounting Research. v. 38. 2000. p.1-21. ALMEIDA, José Elias Feres de. Earnings management no Brasil: estudo empírico em indústrias e grupos estratégicos. Vitória, 2006. Dissertação (Mestrado em Ciências Contábeis) - Programa de Pós-Graduação em Ciências Contábeis da Fundação Instituto Capixaba de Pesquisas em Contabilidade, Economia e Finanças.

ANDERSON, David R.; et al. Statistics for business and economics. 8th ed. Ohio: Thomson Learning, 2002.

ARYA, Anil et al. Earnings management and the revelation principle. Review of Accounting Studies. New York: v. 3, n. 1-2, p. 7-34, mar. 1998.

BAGNOLI, Mark; WATTS, Susan G. the effect of relative performance evaluation on earnings management: a game-theoretic approach. Journal of Accounting and Public Policy. New York: v. 19, n.4-5, p. 377-397, winter 2000.

BALL, Ray. Discussion the association between firms' value and accounting numbers after adoption of fresh start reporting. Journal of Accounting, Auditing and Finance. Connecticut: v. 14, n.3, p.212-218, summer 1999.

; SHIVAKUMAR, Lakshmanan. Earnings quality UK private firms: comparative loss recognition timeliness. Journal of Accounting and Economics. New York: v. 39, n.1, p.83-128, feb. 2005.

; et al. The effect of international institutional factors on properties of accounting earnings. Journal of Accounting and Economics. New York: v. 29. n.1, p.1-51, feb. 2000.

BALTAGI, Bahi H.. Econometrics analysis of panel data. 3rd ed. London: Wiley, 2002.

BARTH, Mary E.; et al. Accruals and prediction of future cash flows. The Accounting Review. Sarasota: v. 76, n.1, p.27-58, jan. 2001.

BARTON, Jan; SIMKO, Paul J. The balance sheet as an earnings management constraint. The Accounting Review. Sarasota: v. 77, n.4, p.1-27, supplement 2004.

BARTOV, Eli et al. The rewards to meeting or beating earnings expectations. Journal of Accounting and Economics. New York: v. 33, n.2, p.173-204, jun. 2002.

; MOHANRAM, Partha. Private information, earnings manipulations, and

executive stock-options exercises. The Accounting Review. Sarasota: v. 79, n.4, p.889-920, oct. 2004.

BASU, Sudipta. The conservatism principle and the asymmetric timeliness of earnings. Journal of Accounting and Economics. New York: v. 24, v.1, p.3-37, dec. 1997.

BAZERMAN, Max H. Processo decisório. 5.ed. Rio de Janeiro: Elsevier, 2004.

BEAVER, William H. Directions in accounting research: NEAR and FAR. Accounting Horizons. Sarasota: v. 10, n. 2, p. 113-124, jun. 1996.

. Financial reporting: an accounting revolution. 3rd ed. New Jersey: Prentice Hall, 1998.

BECKER, Connie L. et al. The effect of audit quality on earnings management.. Contemporary Accounting Research. Toronto: v. 15, n.1, p.1-24, spring 1998.

BENEISH, Messod D. Detecting GAAP violation: implications for assessing earnings management among firms with extreme financial performance. Journal of Accounting and Public Policy. New York: v. 16, n.3, p. 271-309, fall 1997. 
. Earnings management: a perspective. Managerial Finance. West Yorkshire: v. 27, n.12, p.3-18, dec. 2001.

BRASIL. Secretaria da Receita Federal. Análise da arrecadação das receitas federais. Brasília, 2006a. Disponível em: <http://www.receita.fazenda.gov.br $>$. Acesso em: 25/01/2007.

. Secretaria da Receita Federal. Carga tributária no Brasil 2005. Brasília, 2006b. Disponível em: $<$ http://www.receita.fazenda.gov.br>. Acesso em: 25/01/2007.

. Comissão de Valores Mobiliários (CVM). Ofertas registradas. Brasília, 2007. Disponível em: $<$ http://www.cvm.gov.br>. Acesso em: 02/08/2007.

BURGSTAHLER, David C., DICHEV, Ilia. Earnings management to avoid earnings decrease and losses. Journal of Accounting and Economics. New York: v. 24, n.1, p.99126, dec. 1997.

et al. The importance of reporting incentives: earnings management in European private and public firms. The Accounting Review. Sarasota: v. 81, n.5. p.983-1016, oct. 2006.

BUSHMAN, Robert M.; SMITH, Abbie J. Financial accounting information and corporate governance. Journal of Accounting and Economics. New York: v. 32, n.1-3, p.237-333, dec. 2001.

CARDOSO, Ricardo Lopes. Regulação econômica e escolhas de práticas contábeis: evidências no mercado de saúde suplementar. São Paulo, 2005. Tese (Doutorado em Ciências Contábeis) - Programa de Pós-Graduação em Ciências Contábeis, Departamento de Contabilidade e Atuária, Faculdade de Economia, Administração e Contabilidade da Universidade de São Paulo.

; MARTINEZ, Antônio Lopo. Gerenciamento de resultados contábeis no Brasil mediante decisões operacionais. In: ENCONTRO DA ASSOCIAÇÃO NACIONAL DOS PROGRAMAS DE PÓS-GRADUAÇÃO EM ADMINISTRAÇÃO - ENANPAD, 30, 2006, Salvador. Anais... Salvador: ANPAD, 2006. CD-ROM.

CERVO, Amado L., BERVIAN, Pedro A. Metodologia científica. 5.ed. São Paulo: Prentice Hall, 2002.

CHAMBERS, Dennis J Earnings management and capital market misallocation. Working Papers. University of Illions, dec., 1999. Disponível em: <http://www.ssrn.com>. Acesso em: 30/09/2006.

CHIANG, Alpha C.; WAINWRIGHT, Kevin. Matemática para economistas. Rio de Janeiro: Elsevier, 2006.

CHOI, Frederick et al. International accounting. 3rd ed. New Jersey: Prentice Hall, 1999.

CHURCHILL JR., Gilbert A A paradigm for developing better measures of marketing constructs. Journal of Marketing Research. Illinois: v. 16, n. 1, p.64-73, feb. 1979.

COHEN, Daniel A. et al. Trends in earnings management and informativeness of earnings announcements in the pre- and post-Sarbanes Oxley periods. Working paper: Northwestern University, feb. 2005. Disponível em: <http://www.ssrn.com>. Acesso em: 15/11/2006 COOPER, Donald R.; SCHINDLER, Pamela S. Métodos de pesquisa em administração. 7.ed. Porto Alegre: Bookman, 2003.

COZBY, Paul C. Métodos de pesquisa em ciências do comportamento. São Paulo: Atlas, 2003.

CRONBACH, Lee J. Fundamentos da testagem empírica. 5. ed. Porto Alegre: Artes Médicas, 1996.

DARROUGH, Masako; RANGAN, Srinivasan. Do insiders manipulate earnings when they sell their shares in an initial public offering? Journal of Accounting Research. Oxford: v. 43, n.1, p.1-33, mar. 2005. 
DAVIDSON, Russell; MACKINNON, James G. Econometric theory and methods. New York: Oxford University Press, 2003

DeANGELO, Linda E. Accounting numbers as market valuation substitutes: a study of management buyouts of public stockholders. The Accounting Review. Sarasota: v. 61, n.3, p.400-420, jul. 1986.

DECHOW, Patricia M. Accounting earnings and cash flows as measures of firm performance: the role of accounting accruals. Journal of Accounting and Economics. New York: v. 18, n.1-2, p.3-42, jan. 1994.

; DICHEV, Ilia D. The quality of accruals and earnings: the role of accrual estimation errors. The Accounting Review. Sarasota: v. 77, n.4, supplement, p.35-59, oct. 2002.

Institute, 2004.

; SCHRAND, Catherine M. Earnings quality. Charlottesville (Virginia): CFA

; SKINNER, Douglas J. Earnings management: reconciling the views of accounting academics, practitioners, and regulators. Accounting Horizons. Sarasota: v. 14, n.2, p.235250, jun. 2000.

et al. Detecting earnings management. The Accounting Review. Sarasota: v. 70, n.2, p.193-225, apr. 1995.

et al. The relation between earnings and cash flows. Journal of Accounting and Economics. New York: v. 25, n.2, p.133-168, may 1998.

et al. Why are earnings kinky? An examination of the earnings management explanation. Review of Accounting Studies. New York: v. 8, n. 2-3, p. 355-384, jun.-sep. 2003.

DeFOND, Mark L.; SUBRAMANYAM, K. R. Auditor changes and discretionary accruals. Journal of Accounting and Economics. New York: v. 25, n.1, p.35-67, feb. 1998.

DEMSKI, Joel S. Endogenous expectations. The Accounting Review. Sarasota: v. 79, n.2, p.519-539, apr. 2004.

Accounting and economics. In: NEWMAN, Peter (Org.). The new palgrave dictionary of economics. 2nd ed. New York: Palgrave Macmillan, forthcoming 2005. Disponível em: < http://bear.cba.ufl.edu/demski/>. Acesso em: 12/12/2005

Analytic Modeling in Management Accounting Research. In: CHAPMAN,

Christopher et al (Org.). Handbook of Management Accounting Research. Amsterdam: Elsevier Science, 2006. Disponível em: <http://bear.cba.ufl.edu/demski/>. Acesso em: $15 / 11 / 2006$.

; FRIMOR, Hans. Performance measure garbling under renegotiation in multiperiod agencies. Journal of Accounting Research. Oxford: v. 37, n.3, p.187-214, supplement 1999.

DUNCAN, James R.; KNOBLETT, James A. Investigating behaviour antecedents of earnings management. Research on Accounting Ethics. Connection: v. 6, p.27-66, 2000.

ECHAMBADI, Raj et al. Encouraging best practice in quantitative management research: an incomplete list of opportunities. Journal of Management Studies. Oxford: v. 43, n.8, p.1801-1820, dec. 2006.

EDWARDS, Edgar O.; BELL, Philip W. The theory and measurement business income. California: University California Press, 1961.

ELIFOGLU, I. Hilmi; FITZSIMONS, Adrian P. SEC issues study on the adoption of a principles-based accounting system. Bank Accounting \& Finance. Chicago: v.17, n.1, p.3442, dez. 2003.

EWERT, Ralf; WAGENHOFER, Alfred. Economic effects of tightening accounting standards to restrict earnings management. The Accounting Review. Sarasota: v. 80, n.4, p.1101-1124, oct. 2005. 
EVRARD, Yves; et al. Market: Études et recherches em marketing. Paris: Nathan, 1993 FIELDS, Thomas D.; et al. Empirical research on accounting choice. Journal of Accounting and Economics. New York: v. 31, n.1-3, p.255-307, sep. 2001.

FINGER, Catherine A. The Ability of Earnings to Predict Future Earnings and Cash Flow. Journal of Accounting Research. Oxford: v. 32, n.2, p.210-223, autumn 1994.

FIPECAFI - Fundação Instituto de Pesquisas Contábeis, Atuárias e Financeiras. Manual de contabilidade das sociedades por ações: aplicável às demais sociedades. 7. ed. São Paulo: Atlas, 2007.

FORTUNA, Eduardo. Mercado financeiro: produtos e serviços. 16. ed. Rio de Janeiro: Qualitymark, 2005.

FRANCIS, Jennifer. Discussion of empirical research on accounting choice. Journal of Accounting and Economics. New York: v. 31, n.1-3, p.309-319, sep. 2001.

FUJI, Alessandra Hirano. Gerenciamento dos resultados contábeis no âmbito das instituições financeiras atuantes no Brasil. São Paulo, 2004. Dissertação (Mestrado em Ciências Contábeis) - Programa de Pós-Graduação em Ciências Contábeis, Departamento de Contabilidade e Atuária, Faculdade de Economia, Administração e Contabilidade da Universidade de São Paulo.

GINER, Begoña; REES, William. On the asymmetric recognition of good and bad news in France, Germany and the United Kingdom. Journal of Business Finance \& Accounting. Oxford: v. 28, n. 9-10, p.1285-1331, nov. 2001.

GIROUX, Gary. Detecting earnings management. New Jersey: John Wiley \& Sons, 2004.

GIVOLY, Dan; HAYN, Carla. The changing time-series properties of earnings, cash flows and accruals: has financial reporting become more conservative? Journal of Accounting and Economics. New York: v. 29, n.3, p.287-320, jun. 2000.

GORDON, Elizabeth A.; JOOS, Peter R. Unrecognized deferred taxes: evidence from the U.K. The Accounting Review. Sarasota: v. 79, n.1, p.97-124, jan. 2004.

GRAHAM, John R.; et al. The economic implications of corporate financial reporting. Journal of Accounting and Economics. New York: v. 40, n.1-3, p.3-73, dec. 2005.

GRAMLICH, Jeffrey et al. Balance sheet management: the case of short-term obligations reclassified as long-term debt. Journal of Accounting Research. Oxford: v. 39, n.2, p.269282, sep. 2001.

GRAVA, João William.A anatomia da governança corporativa no Brasil e o desempenho econômico da firma: uma análise estatística exploratória das empresas de capital aberto no período de 1997 a 2000. São Paulo, 2004. Tese (Doutorado em Economia) - Programa de Pós-Graduação em Economia, Departamento de Economia, Faculdade de Economia, Administração e Contabilidade da Universidade de São Paulo.

GREENE, William H. Econometric analysis. 5th ed. New Jersey: Prentice Hall, 2003.

GU, Zhaoyang; et al. What determines the variability of accounting accruals? Review of Quantitative Finance and Accounting. Dordrecht: v. 24, n. 3, p.313-334, may. 2005.

GUAY, Wayne R.; et al. A market-based evaluation of discretionary accrual models. Journal of Accounting Research. Oxford: v. 34, n.3, p.83-105, supplement 1996.

GUJARATI, Damodar N. Econometria básica. 4. ed. Rio de Janeiro: Elsevier, 2006.

GUNNY, Katherine. What are the consequences of real earnings management? Working Papers. University of Colorado, sep., 2005. Disponível em: <http://www.ssrn.com>. Acesso em: 03/09/2006.

HAIR JR, Joseph F. et al. Análise multivariada de dados. 5. ed. Porto Alegre: Bookman, 2005.

HEALY, Paul M. The effect of bonus schemes of accounting decisions. Journal of Accounting and Economics. New York: v. 7, n.1-3, p.85-107, apr. 1985. 
. Discussion of a market-based evaluation of discretionary accrual models. Journal of Accounting Research. Oxford: v. 34, n.3, p.107-115, supplement 1996.

; PALEPU, Krishna G. Information asymmetry, corporate disclosure, and the capital markets: a review of the empirical disclosure literature. Journal of Accounting and Economics. New York: v. 31, n.1-3, p.405-440, sep. 2001.

; $\quad$. The fall of Enron. Journal of Economic Perspectives. Nashville: v. 21, n.17, p.3-26, spring. 2003.

; WAHLEN, James M. A review of the earnings management literature and its implications for standard setting. Accounting Horizons. Sarasota: v. 13, n.4, p.365-383, dec. 1999.

HENDRICKSEN, Eldon S.; VAN BREDA, Michael F. Teoria da contabilidade. São Paulo: Atlas, 1999.

HOLTHAUSEN, Robert W.; LEFTWICH, Richard W. The economic consequences of accounting choice. Journal of Accounting and Economics. New York: v. 5, n.2, p.77-117, aug. 1983 .

; WATTS, Ross L. The relevance of the value-relevance literature for financial accounting standard setting. . Journal of Accounting and Economics. New York: v. 31, n.13, p.3-75, sep. 2001.

HRIBAR, Paul; COLLINS, Daniel W. Errors in estimating accruals: implications for empirical research. Journal of Accounting Research. Oxford: v. 40, n.1, p.105-134, mar. 2002.

IUDÍCIBUS, Sérgio de. Teoria da contabilidade. 7. ed. São Paulo: Atlas, 2004.

Atlas, 2004.

; LOPES, Alexandro Broedel. Teoria avançada da contabilidade. São Paulo:

JONES, Jeniffer J. Earnings management during import relief investigations. Journal of Accounting Research. Oxford: v. 29, n.2, p.193-228, autumn 1991.

KANG, Sok-Hyon.; SIVARAMAKRISHNAN, K. Issues in testing earnings management and an instrumental variable approach. Journal of Accounting Research. Oxford: v. 33, n.2, p.353-367, autumn 1995.

KERLING, Fred N.; LEE, Howard B. Foundations of behavioral research. 4th ed. Ohio: Thomson, 2000.

KOTHARI, S. P.; et al. Performance matched discretionary accrual measures. Journal of Accounting and Economics. New York: v. 39, n.1, p.163-197, feb. 2005.

LARA, Juan Manuel García; et al. The effect of earnings management on the asymmetric timeliness of earnings. Journal of Business Finance and Accounting. v. 32. n. 3-4, p.691725, apr/may. 2005.

LEVIN, Jack; FOX, James Alan. Estatística para ciências humanas. São Paulo: Prentice Hall, 2004.

LIU, Jing; et al. Equity valuation using multiples. Journal of Accounting Research. Oxford: v. 40, n.1, p.135-172, mar. 2002.

LOPES, Alexsandro Broedel. A relevância da informação contábil para o mercado de capitais: o modelo de Ohlson aplicado a Bovespa. São Paulo, 2001. Tese (Doutorado em Ciências Contábeis) - Programa de Pós-Graduação em Ciências Contábeis, Departamento de Contabilidade e Atuária, Faculdade de Economia, Administração e Contabilidade da Universidade de São Paulo.

. A informação contábil e o mercado de capitais. São Paulo: Pioneira Thomson Learning, 2002.

; MARTINS, Eliseu. Teoria da contabilidade: uma nova abordagem. São Paulo: Atlas, 2005.

MADALLA, G. S. Introduction of econometrics. 2nd ed. New York: Macmillam, 1992. 
MARTINEZ, Antônio Lopo. Gerenciamento dos resultados contábeis: estudo empírico das companhias abertas brasileiras. São Paulo, 2001. Tese (Doutorado em Ciências Contábeis) Programa de Pós-Graduação em Ciências Contábeis, Departamento de Contabilidade e Atuária, Faculdade de Economia, Administração e Contabilidade da Universidade de São Paulo.

MARTINS, Eliseu. Contabilidade versus fluxo de caixa. Caderno de Estudos da Fipecafi. São Paulo: n. 20, p. 1-10, jan.-abr. 1999.

. Análise critica de balanços: parte I. Boletim IOB Temática Contábil e Balanços.

São Paulo: IOB, n. 26, p. 1-8, 2005a.

Análise critica de balanços: parte II. Boletim IOB Temática Contábil e

Balanços. São Paulo: IOB, n. 26, p. 1-9, 2005 b.

MARTINS, Gilberto de Andrade. Manual para elaboração de monografias e dissertações. 3. ed. São Paulo: Atlas, 2002.

MAS-COLLEL, Andreu et al. Microeconomic theory. New York: Oxford University Press, 1995.

MAZZON, José Afonso. Formulação de um modelo de avaliação e comparação de modelos em marketing. São Paulo, 1978. Dissertação (Mestrado em Administração) Programa de Pós-Graduação em Administração, Departamento de Administração, Faculdade de Economia, Administração e Contabilidade da Universidade de São Paulo.

McKEE, Thomas E. Earnings management: an executive perspective. Ohio: Thomson, 2005. McLEAY, Stuart J. Discussion of the effect of earnings management on the asymmetric timeliness of earnings. Journal of Business Finance and Accounting. v. 32. n. 3-4, p.727735, apr/may. 2005.

McNICHOLS, Maureen. Research design issues in earnings management studies. Journal of Accounting and Public Policy. New York: v. 19, n.4-5, p. 313-345, winter 2000.

. Discussion of the quality of accruals and earnings: the role of accrual estimation errors. The Accounting Review. Sarasota: v. 77, n.4, supplement, p.61-69, oct. 2002.

; WILSON, G. Peter. Evidence of earnings management from the provision for bad debts. Journal of Accounting Research. Oxford: v. 26, n.3, p.1-31, supplement 1988.

MICHAELIS. Moderno dicionário da lingua portuguesa. São Paulo: Melhoramentos, 1998.

MYERS, James N. et al. Earnings momentum and earnings management. Working paper: Texas A\&M University, aug. 2006. Disponível em: <http://www.ssrn.com>. Acesso em: $15 / 11 / 2006$

NELSON, Mark W. Behavioral evidence on the effects of principles - and rules-based standards. Accounting Horizons. Sarasota: v. 17, n. 1, p. 91-104, mar. 2003.

NEWBOLD, Paul; et al. Statistics for business and economics. 5th ed. New Jersey: Prentice Hall, 2002.

NICHOLSON, Walter. Microeconomic theory: basic principles and extensions. 8th ed. Ohio: South-Western College Pub, 2002

NIYAMA, Jorge K. Contabilidade internacional. São Paulo: Atlas, 2005.

PAE, Jinhan. Expected accrual models: the impact of operating cash flows and reversals of accruals. Review of Quantitative Finance and Accounting. Dordrecht: v. 24, n. 1, p.5-22, feb. 2005.

PALEPU, Krishna G. et al. Business analysis e valuation: using financial statements. $3 \mathrm{rd}$. Ohio: Thomson Learning, 2004.

PAULO, Edilson; et al. Estudo sobre o conservadorismo nas companhias abertas e fechadas brasileiras. In: ENCONTRO DA ASSOCIAÇÃO NACIONAL DOS PROGRAMAS DE PÓS-GRADUAÇÃO EM ADMINISTRAÇÃO - ENANPAD, 30, 2006, Salvador. Anais... Salvador: ANPAD, 2006. CD-ROM. 
PEASNELL, Ken V.; et al. Detecting earnings management using cross-sectional abnormal accruals models. Accounting and Business Research. London: v. 30, n. 4, p.313-326, autumn 2000.

PESTANA, Maria Helena.; GAGEIRO, João Nunes. Análise de dados para ciências sociais: a complementariedade do SPSS. 4. ed. Lisboa: Sílabo, 2005.

PETER, J. Paul. Construct validity: a review of basic issues and marketing practices. Journal of Marketing Research. Illinois: v. 18, n. 2, p.133-145, may 1981.

PINDYCK, Robert S.; RUBINFELD, Daniel L. Econometria. 4. ed. Rio de Janeiro: Elsevier, 2004.

Microeconomia. 6. ed. São Paulo: Pearson Prentice Hall, 2006.

PIOT, Charles. Auditing quality and earnings management in France Working Papers. Pierre Mendés France University, jul. 2005. Disponível em: <http://www.ssrn.com>. Acesso em: 27/02/2006.

POPE, Peter F.; WALKER, Martin. International differences in the timeliness, conservatism, and classification of earnings. Journal of Accounting Research. Oxford: v. 37, n.3, p.53-87, supplement 1999.

POTTER, Bradley N. Accounting as social and institutional practice: perspectives to enrich our understanding of accounting change. Abacus. Sidney: v. 41, n. 3, p. 265-289, oct. 2005.

RAJAN, Raghuram; SERVAES, Henri. Analyst following of initial public offerings. Journal of Finance. Oxford: v. 52, n. 2, p.507-529, jun. 1997.

RIAHI-BELKAOUI, Ahmed. Accounting theory. 4th ed. London: Thomson Learning, 2000.

ROOSENBOOM, Peter; et al. Earnings management and initial public offerings: evidence from the Netherlands. The International Journal of Accounting. Oxford: v. 38, n.3, p. 243266, 2003.

ROYCHOWDHURY, Sugata. Earnings management through real activities manipulation. Journal of Accounting and Economics. New York: v. 42, n.3, p. 335-370, dec. 2006.

SANTOS, Ariovaldo dos; PAULO, Edilson. Diferimento das perdas cambiais como instrumento de gerenciamento de resultados. Brazilian Business Review. Vitória-ES: v. 3, n. 1, p. 15-31, jan.-jun. 2006.

SCHIPPER, Katherine. Commentary on earnings management. Accounting Horizons. Sarasota: v. 3, n.4, p.91-102, dec. 1989.

. Principles-based accounting standards. Accounting Horizons. Sarasota: v. 17, n. 1, p. 61-72, mar. 2003.

SCHROEDER, Richard G et al. Financial accounting: theory and analysis. 7th ed. New York: John Wiley \& Sons, 2001.

SCOTT, William R. Financial accounting theory. 3rd ed. Toronto: Prentice Hall, 2003.

SEVERINO, Antônio Joaquim. Metodologia do trabalho científico. 22. ed. São Paulo: Cortez, 2002.

SHACKELFORD, Douglas A.; SHEVLIN, Terry. Empirical tax research in accounting. Journal of Accounting and Economics. New York: v. 31, n.1-3, p.321-387, sep. 2001.

SILVA, Orlando M.; CRUZ JÚNIOR, José César. Dados em painel: uma análise do modelo estático. In: SANTOS, Maurinho L.; VIEIRA, Wilson da Cruz (Org.). Métodos quantitativos em economia. Viçosa (MG): Editora UFV, 2004.

SLOAN, R. G. Financial accounting information and corporate governance: a discussion. Journal of Accounting and Economics. New York: v. 32, n.1-3, p. 335-347, dec. 2001.

SOARES, Ilton G.; CASTELAR, Ivan. Econometria aplicada com o uso do Eviews. Fortaleza: UFC/CAEN, 2003.

STOLOWY, Herve; BRETON, Gaetan. Accounts manipulation: a literature review and proposed conceptual framework. Review of Accounting and Finance. East Yorkshire: v. 3, n. 1. 2004. p. 5-66 
SUBRAMANYAM, K. R. The pricing of discretionary accruals. Journal of Accounting and Economics. New York: v. 22, n. 1-3, p. 249-281, aug-dec. 1996.

SUNDER, Shyam. Theory of accounting and control. Cincinnati: South-Western Publishing, 1997.

TABACHNICK, Barbara G.; FIDELL, Linda S. Using multivariate statistics. 4th ed. New Jersey: Pearson, 2001.

TEOH, Siew Hong; WONG, T. J. Analysts' credulity about reported earnings and overoptimism in new equity issues. Working paper: Ohio State University, 1997. Disponível em: <http://www.ssrn.com>. Acesso em: 27/02/2006.

; et al. Earnings management and the long-run market performance of initial public

offerings. Journal of Finance, Oxford: v. 53, n. 6, p. 1935-1974, dec. 1998.

THEÓPILO, Carlos Renato. Pesquisa em contabilidade no Brasil: uma análise críticoepistemológica. São Paulo, 2004. Tese (Doutorado em Ciências Contábeis) - Programa de Pós-Graduação em Ciências Contábeis, Departamento de Contabilidade e Atuária, Faculdade de Economia, Administração e Contabilidade da Universidade de São Paulo.

THOMAS, Jacob; ZHANG, Xiao-jun. Identifying unexpected accruals: a comparison of current approaches. Journal of Accounting and Public Policy. New York: v. 19, n.4-5, p. 347-376, winter 2000.

TUKAMOTO, Yhurika Sandra. Contribuição ao estudo do "gerenciamento" de resultados: uma comparação entre as companhias abertas brasileiras emissoras de ADRs. São Paulo, 2004. Dissertação (Mestrado em Ciências Contábeis) - Programa de Pós-Graduação em Ciências Contábeis, Departamento de Contabilidade e Atuária, Faculdade de Economia, Administração e Contabilidade da Universidade de São Paulo.

VERRECCHIA, Robert E. Essays on disclosure. Journal of Accounting and Economics. New York: v. 32, n.1-3, p.97-180, dec. 2001.

VICENT, Linda; et al. Evaluating concepts-based vs. rules-based approaches to standard setting. Accounting Horizons. Sarasota: v. 17, n. 1, p. 73-89, mar. 2003.

VUONG, Quang H.. Likelihood ratio tests for model selection and non-nested hypotheses. Econometrica. New Jersey: v. 57, n. 2, p. 307-333, mar. 1989.

WAGENHOFER, Alfred. Accounting and economics: what we learn from analytical models in financial accounting and reporting. In: LEUZ, Christian et al (Org.). The economics and politics of accounting international: perspectives on research trends, policy, and practice. New York: Oxford University Press, 2004.

WATTS, Ross L. Conservatism in accounting part $I$ : explanations and implications. Accounting Horizons. Sarasota: v. 17, n.3, p. 207-221, sep. 2003 a.

. Conservatism in accounting part II: evidence and research opportunities.

Accounting Horizons. Sarasota: v. 17, n.4, p. 287-301, dec. 2003 b.

Hall, 1986.

; ZIMMERMAN, Jerold L. Positive accounting theory. New Jersey: Prentice

WEFFORT, Elionor F. J. O Brasil e a harmonização contábil internacional. São Paulo: Atlas, 2005.

WOLK, Harry I. et al. Accounting theory: a conceptual and institutional approach. Cincinnati: South-Western College Pub, 1992.

WOOLDRIDGE, Jeffrey M. Econometric analysis of cross section and panel data. London: MIT Press, 2001.

Introductory econometrics: a modern approach. 2nd ed. Ohio: South-Western

College Pub, 2002.

XIONG, Yan. Earnings management and its measurement: a theoretical perspective. The Journal of American Academy of Business. Florida: v.9, n. 1, p.214-219, mar. 2006. 
YERMACK, D. Good timing: CEO stock options awards and company news announcements. Journal of Finance. Oxford: v. 52, n.2, p. 449-476, jun. 2002.

YOUNG, Steven. Systematic measurement yerror in the estimation of discretionary accruals: an evaluation of alternative modelling procedures. Journal of Business Finance \& Accounting. Oxford: v. 26, n. 7-8, p.833-862, sep./oct. 1999.

YU, Frank. Analyst coverage and earnings management. Working Papers. University of Minessota, feb., 2006. Disponível em: <http://www.ssrn.com>. Acesso em: 03/12/2006.

ZANG, Amy Y. Evidence on the tradeoff between real manipulation and accruals manipulation. Working Papers. Fuqua School of Business, dec., 2005. Disponível em: $<\mathrm{http}$ ://accounting.eller.arizona.edu>. Acesso em: 03/01/2007.

ZEFF, Stephen A. The rise of economic consequences. The Journal of Accountancy. New Jersey: v. 146, n.6, p. 56-63, dec. 1978.

ZENDERSKY, Humberto Carlos. Gerenciamento de resultados em instituições financeiras no Brasil: 2000 a 2004. Brasília, 2005. Dissertação (Mestrado em Ciências Contábeis) - Programa Multiinstitucional e Inter-regional de Pós-Graduação em Ciências Contábeis, Universidade de Brasília, Universidade Federal da Paraíba, Universidade Federal de Pernambuco e Universidade Federal do Rio Grande do Norte. 


\section{GLOSSÁRIO}

Accrual: conceito contábil empregado para atender ao regime de competência (accruals basis) e que busca mensurar o resultado no sentido econômico, independentemente da realização financeira das transações e eventos.

Accruals discricionários: accruals artificiais e têm como objetivo somente manipular o resultado contábil. Nas pesquisas empríricas, é considerado como proxy para o gerenciamento de resultados contábeis.

Accruals não-discricionários: accruals que são inerentes às atividades da empresa. Componentes não gerenciados do volume total dos accruals.

Assimetria informacional: fenômeno que, normalmente, ocorre quando um determinado agente ou grupo de agentes presentes no ambiente econômico tem melhores informações sobre o potencial econômico do ativo do que um outro agente ou grupo de agentes.

Conceitualização: processo de fundamentação teórica que fornece suporte para a descrição do modelo teórico e se estabelece na realidade na qual se originou o problema, os objetivos e as hipóteses de pesquisa.

Conservadorismo: dimensão da qualidade das informações contábeis. Reconhecimento enviesado das más notícias, mais rapidamente do que as boas notícias. É o resultado que reflete as más notícias (bad news), mais rapidamente do que as boas notícias (good news), levando às diferenças sistemáticas entre os períodos das más notícias e das boas notícias no timeless e persistência dos resultados.

Constructo: compreende a parte de uma construção básica que conecta o desenvolvimento da teoria ao teste. $\mathrm{O}$ constructo organiza o conhecimento e direciona a pesquisa em um tentativa para descrever e explicar algum aspecto da natureza.

Escolhas contábeis: a informação contábil é influenciada pela existência de critérios alternativos de mensuração e evidenciação, fazendo com que o administrador possa escolher dentre as normas e práticas permitidas pela regulamentação contábil, quando essa existir.

Evidência: conjunto de resultados da pesquisa, segundo a metodologia adotada e fruto do emprego do modelo teórico e operacional proposto. A evidência é contraposta à realidade, no qual o pesquisador analisa se as hipóteses levantadas anteriormente são comprovadas ou não e busca explicações para elas.

Fraude contábil: prática contábil que estão fora das normas contábeis aceitas. 
Gerenciamento de resultados: forma de manipulação das informações contábeis. Ocorre quando os administradores usam as escolhas contábeis para alterar informações contábeis com o objetivo de influenciar análise empresarial.

Income minimization: comportamento discricionário que consitem na diminuição dos resultados correntes ou na divulgação de prejuízos contábeis, semelhante ao taking a bath, mas menos extrema.

Income maximization: comportamento discricionário que consitem em elevar os resultados conforme os interesses dos gestores da empresa, e estão relacionados, normalmente, ao plano de remuneração dos administradores, debt covenants, etc.

Income smoothing: comportamento discricionário que consitem na redução da volatilidade dos resultados reportados.

Intermediários da informação: agentes participantes do processo comunicação do desempenho das atividades empresariais e que apresentam conjuntos de informações sobre a qualidade da empresa e de seus gestores, contribuindo para a avaliação e/ou tomada de decisão de seus usuários. Entre os principais intermediários da informação nos diversos mercados financeiros estão Contabilidade, auditoria independente, órgãos reguladores e/ou fiscalizadores, bancos de investimentos e analistas financeiros.

Manipulação classificatória das informações contábeis: forma de manipulação contábil por meio da reclassificação dos elementos contidos nas demonstrações contábeis.

Manipulação das informações contábeis: conjunto de práticas desenvolvidas pelos administradores por meio das escolhas das contábeis e/ou alteração das atividades operacionais (reais) normais da empresa, com o objetivo de interferir, intencionalmente, na informação contábil reportada e, conseqüentemente, afetar a análise do desempenho da empresa ou influenciar as relações contratuais que dependam dos números contábeis.

Manipulação das atividades operacionais (real earnings management): forma de manipulação que ocorre quando os administradores desenvolvem ações que desviam da melhor decisão (the first best practice) para ajustar os resultados reportados a suas necessidades. Forma de gerenciamento de resultados por meio das ações da administração que desviam das práticas normais do negócio com o objetivo principal de atingir certos níveis de resultados.

Modelagem: processo em que pesquisador desenvolve um modelo operacional ou constructo.

Modelo operacional: forma de instrumentalização do modelo teórico, sendo o elemento de ligação entre o modelo teórico e a evidência.

Modelo teórico: abstração da realidade. 
Persistência de resultados: uma dimensão da qualidade dos resultados. Somente se os resultados verdadeiramente refletir o desempenho durante o período e se o desempenho do período corrente persiste nos períodos futuros. Esse conceito está no papel que exerce na previsão dos resultados futuros e, conseqüentemente, na avaliação do valor dos ativos. Quando ocorrem erros nas estimações dos accruals e resultados transitórios, como ganhos e perdas em instrumentos financeiros marcados a mercado, reduzem a persistência dos resultados e isso leva à perda da utilidade dos resultados no papel de avaliação e previsões.

Perspectiva de eficiência: abordagem de pesquisa contábil que observa o funcionamento dos contratos da firma, o sistema de controle interno (inclui o monitoramento por partes dos conselhos internos) e quais os fatores que motivam os gestores a escolherem procedimentos contábeis que reduzam os custos de capital e custos contratuais e minimizem o risco da firma.

Perspectiva oportunística: abordagem de pesquisa contábil na qual se assume que os administradores escolhem políticas contábeis para maximizar suas próprias utilidades esperadas relativas a determinada relação de remuneração, contratos de dívidas e custos políticos.

Pesquisa analítica: tipo de pesquisa cientifica que tem como foco a modelagem (matemática) dos fenômenos contábeis e econômicos com objetivo de gerar proposições testáveis empiricamente.

Pesquisa comportamental; tipo de pesquisa cientifica que emprega os conhecimentos das Ciências Comportamentais para examinar o julgamento e a tomada de decisões dos contadores, administradores, auditores e demais usuários diante da informação contábil.

Pesquisa empírica: tipo de pesquisa cientifica que estuda, principalmente, as diversas relações entre fenômenos, fatores, caracterisitcas e variáveis econômicas. Testam hipóteses através de métodos estatísticos e devem estar respaldados por teorias subjacentes e, em particular, nas teorias e modelos desenvolvidos na pesquisa analítica.

Qualidade das informações contábeis: conceito contábil complexo e que depende do objetivo do seu usuário, podendo assumir diversas perspectivas. Considera-se que existe uma baixa qualidade quando os relatórios contábeis são manipulados. Em muitos casos, os problemas da qualidade da informação contábil estão relacionados ao excessivo montante de itens não recorrentes publicados ou falta de transparência, mesmo quando as escolhas contábeis foram realizadas em concordância com as normas contábeis vigentes.

Risco moral: fenômeno econômico que ocorre quando as ações de um determinado agente não podem ser observadas pelo outro lado da relação contratual e, conseqüentemente, afeta a alocação dos recursos disponíveis.

Seleção adversa: fenômeno econômico que surge quando um agente utiliza informações privadas e não observáveis para atuar de forma oportunística e o principal não seja capaz de verificar se ele agiu segundo interesses próprios. 
Taking a bath: comportamento oportunístico que consiste na diminuição dos resultados correntes ou na divulgação de prejuízos contábeis, normalmente, em períodos de reorganização da empresa e/ou mudança da cúpula administrativa. A intenção é de que, no primeiro momento, a gestão da empresa reconheça o maior volume de possíveis perdas ainda não evidenciadas, 'limpando' nas demonstrações contábeis para aumentar as probabilidades de divulgação de lucros contábeis no futuro. No segundo momento, a administração começa evidenciar melhorias no desempenho da empresa, fazendo com que os usuários da informação avaliem a atual gestão como de boa qualidade.

Validação: processo em que se questiona se os modelos teóricos e operacionais são adequados ao problema e objetivos da pesquisa. 